\title{
Green Energy Options for Consumer-Owned Business
}

Subcontract Report NREL/SR-560-39465

May 2006

Co-opPlus of Western Massachusetts Greenfield, Massachusetts

DIP 


\section{Green Energy Options for Consumer-Owned Business}

Co-opPlus of Western Massachusetts Greenfield, Massachusetts

NREL Technical Monitor: Holly Thomas

Prepared under Subcontract No. ZAT-4-33658-01

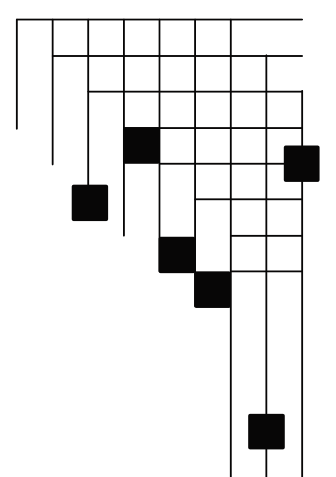




\section{NOTICE}

This report was prepared as an account of work sponsored by an agency of the United States government. Neither the United States government nor any agency thereof, nor any of their employees, makes any warranty, express or implied, or assumes any legal liability or responsibility for the accuracy, completeness, or usefulness of any information, apparatus, product, or process disclosed, or represents that its use would not infringe privately owned rights. Reference herein to any specific commercial product, process, or service by trade name, trademark, manufacturer, or otherwise does not necessarily constitute or imply its endorsement, recommendation, or favoring by the United States government or any agency thereof. The views and opinions of authors expressed herein do not necessarily state or reflect those of the United States government or any agency thereof.

Available electronically at http://www.osti.gov/bridge

Available for a processing fee to U.S. Department of Energy and its contractors, in paper, from:

U.S. Department of Energy

Office of Scientific and Technical Information

P.O. Box 62

Oak Ridge, TN 37831-0062

phone: 865.576 .8401

fax: 865.576 .5728

email: mailto:reports@adonis.osti.gov

Available for sale to the public, in paper, from:

U.S. Department of Commerce

National Technical Information Service

5285 Port Royal Road

Springfield, VA 22161

phone: 800.553 .6847

fax: 703.605.6900

email: orders@ntis.fedworld.gov

online ordering: http://www.ntis.gov/ordering.htm 


\section{Preface}

Engaging in the business development process to create a community-owned biodiesel production facility was the central focus of this National Renewable Energy Laboratory contract. It forms the backbone of the business structure that allows Co-op Power to bring a wide range of sustainable energy products to its members and affiliates. There is tremendous excitement throughout its region moving this process along.

Many people contributed to the underlying research reflected in this report. First of all, we thank the 2,000 members of Co-opPlus, who supported this development effort. We thank Congressman Olver, the National Renewable Energy Laboratory, the Department of Energy, and the United States Department of Agriculture, which assisted us in securing funding for initial business planning and development. We thank Tom Leue, who began this venture based on the 10,000 gallons of biodiesel he produced at his farm. Tom led the early feasibility research that showed this could be a viable option for the cooperative. We thank Lynn Di Tullio for her work on the cogeneration feasibility study. We thank Lawrence Union for his dedication and thoroughness while working through each iteration of the pro forma and overseeing our business development efforts for our biodiesel production facility. And we thank Shaine Tyson and Wes Berry for their assistance reviewing technology options and their business development support.

It's been a very exciting and rewarding project, one we trust will bring significant value to our region.

Lynn Benander Greenfield, Massachusetts

November 2005 


\section{Contents}

List of Figures

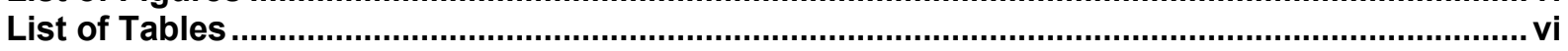

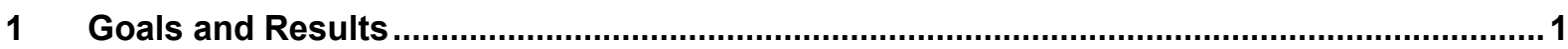

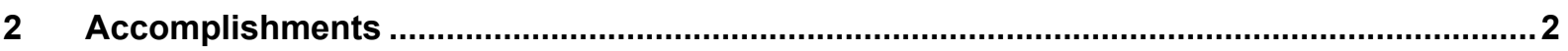

2.1 Task 1: Technical Feasibility and Economic Viability Assessment for

Renewable Energy Products and Services for Either Onsite or Central

Distributed Energy Resources......................................................................... 2

2.2 Task 2: Assessment and Evaluation of Education and Outreach Materials............ 6

2.3 Task 3: Development of an Onsite Distributed Generation Implementation Plan for a Consumer-Owned Cooperative Business .......................................... 7

2.4 Task 5: Development of Centralized Renewable Energy Generation Fuel Production With a Plan for Cogeneration for a Consumer-Owned Cooperative Business Model............................................................................ 10

2.5 Implementation Plan Summary ..................................................................... 19

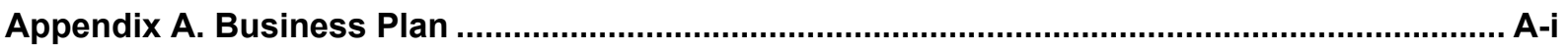

Appendix B. Biodiesel Production Facility Business Plan........................................................ B-i

Appendix C. Study of Cogeneration Feasibility for Northeast Biodiesel LLC.............................. C-i 


\section{List of Figures}

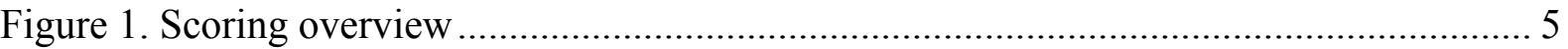

Figure 2. Touchstone Energy market consumer research results..................................... 17

\section{List of Tables}

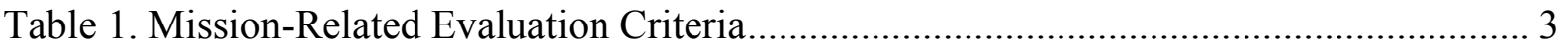

Table 2. Business-Related Evaluation Criteria ................................................................ 4

Table 3. Criteria for Fit With Cooperative Platform ......................................................... 4

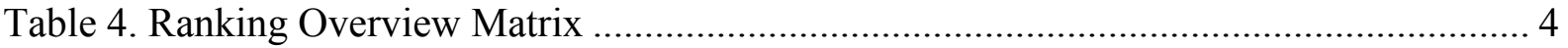

Table 5. Pro Forma for a Recycled Vegetable Oil Collection Service ................................. 13

Table 6. Comparison of Legal Structures for Group-Based Businesses ............................... 15 


\section{Goals and Results}

The goal of this project was to define, test, and prototype a replicable business model for consumer-owned cooperatives. The result is a replicable consumer-owned cooperative business model for the generation, interconnection, and distribution of renewable energy that incorporates energy conservation and efficiency improvements.

The objective of the project was to assess, analyze, and evaluate interconnected renewable energy technologies to identify options for interconnected renewable-sourced electric power and renewable fuels that are technically successful, economically viable for the co-op's needs, and efficient.

The outcomes of the project are:

- A technically feasible and economically viable implementation plan for a consumerowned, renewable-sourced energy business

- A procedural process to advance energy conservation and efficiency improvements and the generation of renewable energy

- A process for working with the local utility to interconnect solar energy systems with a networked grid.

Co-opPlus has supported renewable energy technologies and programs. For example, it has:

- Successfully developed a solar installation program for its members. More than 600 members are in the pipeline for installation, and more than 50 have installed or are in the process of installing a solar energy system.

- Supported the GreenUp program in Massachusetts Electric Co.'s territory. One hundred two of its members purchase the green electricity product.

- Built a new regional cooperative, Co-op Power, to serve as a vehicle for building sustainable energy resources across the region. A member equity share costs $\$ 975$, and there are discount programs for low-income people, farmers, and Co-opPlus members. More than 100 people have joined. Co-op Power now offers a biodiesel blend for home heating that is priced lower than petroleum heating oil. It sells waste vegetable oil burners and offers a discount for products and services on the Energy Federation International Web site. Soon, it will provide a solar hot water kit at a deep discount to its members.

- Built a biodiesel production facility and signed a contract for $75 \%$ of its output. Co-op Power is the majority owner of this renewable fuel plant, which is scheduled to begin construction in November 2005. It will begin with a production capacity of 4.5 million gallons a year and expand to 10 million gallons a year in 2008 . 


\section{Accomplishments}

Co-opPlus of Western Massachusetts completed the assessments, feasibility analyses, and evaluations described in the following tasks and provided reports and deliverables that constitute a detailed business model for consumer-owned cooperative distributed energy resources.

\subsection{Task 1: Technical Feasibility and Economic Viability Assessment for Renewable Energy Products and Services for Either Onsite or Central Distributed Energy Resources}

In this task, Co-opPlus assessed, analyzed, and evaluated the technical feasibility and economic viability of various renewable energy technologies for onsite or central distributed energy resources for a consumer-owned cooperative business model in four counties of Western Massachusetts. This task was accomplished through the following subtasks.

\subsubsection{Subtask 1.1}

Co-opPlus assessed the technical feasibility and economic viability of the following renewable energy products and services:

- Solar electricity systems

- Solar hot water systems

- Biodiesel fuel energy

- Fuel cells

- Wind power

- Cogeneration with renewable fuel.

It also researched the feasibility of developing a renewable energy investment fund to bring local ownership to renewable energy projects.

\subsubsection{Subtask 1.2}

Co-opPlus assessed the technical feasibility and economic viability of onsite energy generation and grid interconnection, central energy production, and a combination of these approaches for each of the products and services listed in Subtask 1.1. The assessment determined:

- The technical requirements of installing and integrating these products or services under a consumer-owned cooperative business model

- The most sustainable economic options for a consumer-owned cooperative business model. 


\subsubsection{Subtask 1.3}

Using the assessment results, Co-opPlus evaluated and rank-ordered the renewable energy products and services with respect to their technical development; feasibility, including their potential for grid interconnection; purchase cost; and applicable use under a consumer-owned cooperative business model. It also assessed economic factors - such as bulk purchases, group contracts, and financial support through incentives, energy-related financing, and other subsidies - with respect to usefulness, applicability, and potential effect on a consumer-owned cooperative business model.

The Co-opPlus Task One report detailed its findings on the technical feasibility and economic viability of renewable energy products and services to meet the energy needs of a consumerowned cooperative business. The following is a summary of the criteria used for decision making and the findings.

\subsubsection{Assessment Criteria}

The feasibility research used the criteria listed in tables 1,2, and 3 to evaluate sustainable energy products and services based on the needs and interests of members and basic business principles.

Table 1. Mission-Related Evaluation Criteria

\begin{tabular}{|c|c|}
\hline Criteria & Description \\
\hline Green impact & $\begin{array}{l}\text { - Achieves greatest possible increase in sustainable energy resources } \\
\text { - Increases energy security (Members are specifically focused on decreasing } \\
\text { the reliance on foreign oil.) }\end{array}$ \\
\hline $\begin{array}{l}\text { Local benefit } \\
\text { Educational value } \\
\text { Social benefit }\end{array}$ & $\begin{array}{l}\text { - } \text { Creates or retains jobs and contributes to the local economy } \\
\text { - } \text { Educates the community about sustainable energy resources and practices } \\
\text { - } \text { Makes energy more affordable } \\
\text { - Benefits low- and middle-income households }\end{array}$ \\
\hline
\end{tabular}


Table 2. Business-Related Evaluation Criteria

\section{Criteria}

Economic potential

Low technology risk

Low marketing risk

Low development risk

\section{Description}

Provides ongoing revenue, profit, and return on investment

There is no explicit economic goal beyond break-even; however, sound business practices require some profit for savings or re-investment in the business. This evaluation criterion also includes competitive considerations related to defensibility of new business initiatives and confidence in long-term success.

Does not take technology risks beyond products that are commercially available or otherwise guaranteed to perform at such a level

This includes ongoing maintenance risk. Accommodates low threshold of adoption for members and is easy to understand and use

This is seen as key to the success of any program.

Offers a short timetable from the development of an idea to the completion of a business plan to the successful implementation of a renewable energy initiative.

The cooperative considers itself relatively constrained in terms of manpower and operational bandwidth. Therefore, there is a premium on ideas that can be developed and realized relatively easily.

Table 3. Criteria for Fit With Cooperative Platform

\begin{tabular}{ll}
\hline Criteria & \multicolumn{1}{c}{ Description } \\
\cline { 2 - 3 } Cooperative fit & Positively builds on the four distinctions of a consumer-owned cooperative: \\
(1) The main goal is to meet the needs of members. \\
(2) The cooperative can afford low margin business. \\
(3) The cooperative has high trustworthiness. \\
(4) There is a possible reduction in marketing and transaction costs.
\end{tabular}

\subsubsection{Feasibility Results}

Product options were scored on a scale of 1 to 10 , where 10 is the best score for each criterion (i.e., it fits the criterion most closely).

Table 4. Ranking Overview Matrix

\begin{tabular}{|c|c|c|c|c|c|c|c|c|c|c|c|}
\hline & \multirow[b]{2}{*}{ Rank } & \multirow[b]{2}{*}{$\begin{array}{l}\text { Total } \\
\text { Score }\end{array}$} & \multicolumn{4}{|c|}{ Mission Related Evaluation Criteria } & \multicolumn{4}{|c|}{ Business Related Evaluation Criteria } & \multirow[b]{2}{*}{ Cooperative Fit } \\
\hline & & & $\begin{array}{l}\text { Green } \\
\text { impact }\end{array}$ & Local benefit & $\begin{array}{l}\text { Educational } \\
\text { value }\end{array}$ & $\begin{array}{l}\text { Social } \\
\text { benefit }\end{array}$ & $\begin{array}{c}\text { Economic } \\
\text { potential }\end{array}$ & $\begin{array}{l}\text { Low } \\
\text { technology } \\
\text { risk }\end{array}$ & $\begin{array}{l}\text { Low } \\
\text { development } \\
\text { risk }\end{array}$ & $\begin{array}{l}\text { Low } \\
\text { marketing } \\
\text { risk }\end{array}$ & \\
\hline Biodiesel & 1 & 65 & 7 & 9 & 8 & 6 & 9 & 5 & 6 & 7 & 8 \\
\hline Cogeneration & 2 & 56 & 7 & 5 & 5 & 5 & 8 & 4 & 6 & 9 & 7 \\
\hline Wind Power & 3 & 55 & 8 & 5 & 7 & 6 & 7 & 6 & 2 & 6 & 8 \\
\hline Solar Hot Water & 4 & 53 & 6 & 5 & 7 & 4 & 6 & 7 & 7 & 6 & 5 \\
\hline Solar Electric Systems & 5 & 46 & 2 & 6 & 7 & 2 & 2 & 7 & 8 & 7 & 5 \\
\hline Fuel Cells & 6 & 30 & 2 & 2 & 8 & 2 & 1 & 1 & 2 & 5 & 7 \\
\hline
\end{tabular}




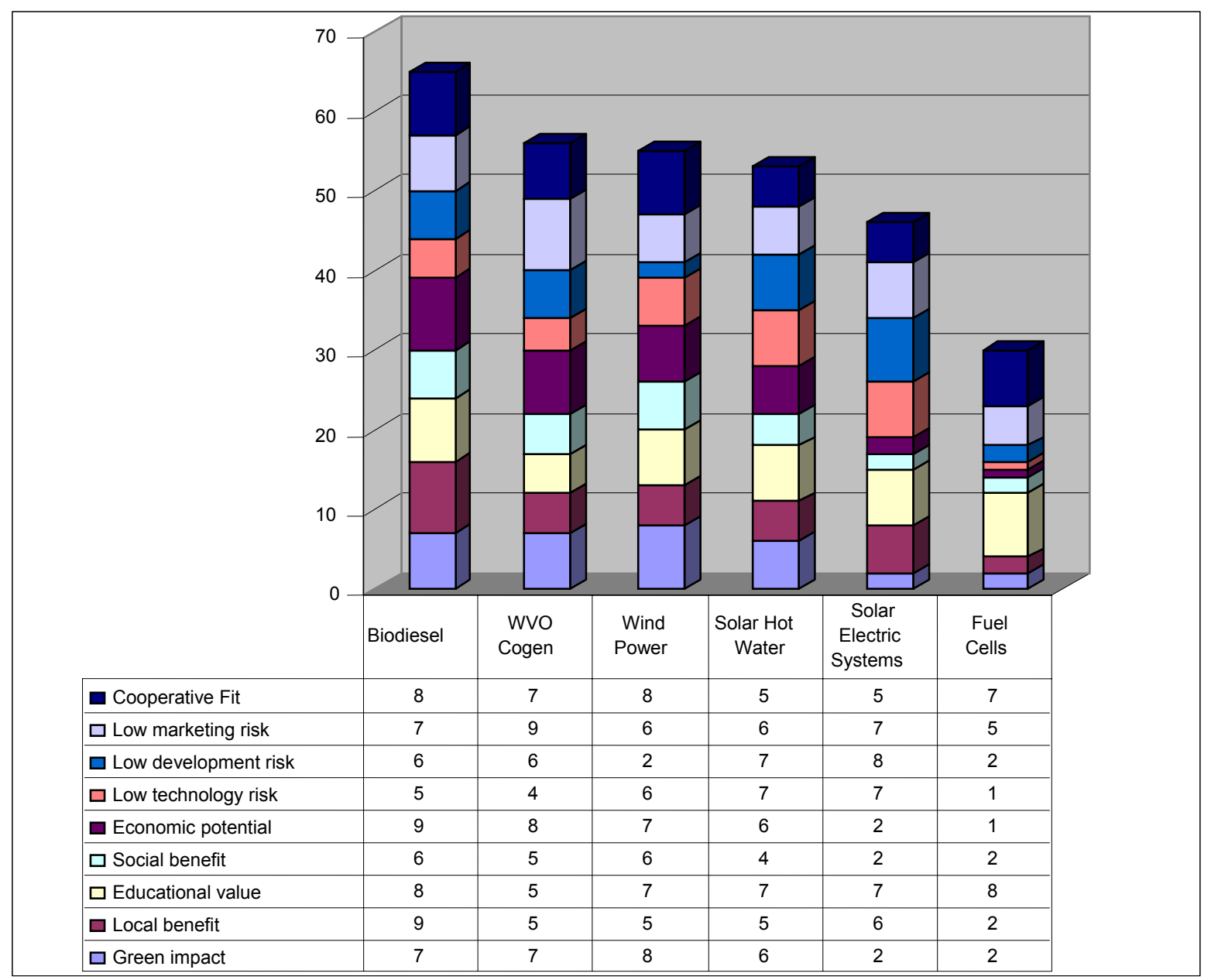

Figure 1. Scoring overview

Biodiesel production returned the highest score, which indicated it was most feasible. (See Figure 1.) This result is based on its strong economic potential, significant local benefits, and educational value. As a consequence, Co-opPlus initiated the development of a full business plan to move this project forward.

Cogeneration represents potential if it is based on waste vegetable oil (WVO) or biodiesel directly. A number of technical and development risks remain for this technology, but if they can be managed up front, it stands a good chance of implementation after the biodiesel production facility is up and running. 
A community wind project remains high on the agenda of Co-opPlus members. Many feel that wind technology is under-represented in the U.S. energy supply. The Massachusetts Technology Collaborative has established a Community Wind Collaborative, and Co-opPlus intends to support future wind projects as they emerge. As with solar technologies, there is a chance that the context for developing a wind project could change positively. These will continue to be monitored. Even without change, Co-opPlus members will continue to look for a local community with a wind site interested in a wind project that the cooperative could throw its energy behind.

Co-opPlus has already succeeded in promoting solar electric systems and solar hot water systems. This program will continue based on a series of marketing agreements with local installers. However, a number of factors could change Co-opPlus involvement in these technologies. Such factors may include:

- Further renewable incentives or subsidies

- Grant opportunities

- Higher electricity prices

- Increased value of renewable energy credits

- Lower system costs.

If any of these factors change in a positive direction, Co-opPlus is in a good position to expand its involvement. This could be by developing systems that are cooperatively owned and locating them at decentralized locations or in one central location (e.g., at a school or the biodiesel facility).

The Co-opPlus feasibility research on a Renewable Energy Investment Fund that would bring large investors together with small local community investors was well received by the Massachusetts Renewable Energy Trust and the Massachusetts Department of Energy Resources. The Massachusetts Renewable Energy Trust and the Massachusetts Department of Energy Resources are following through with the development of this fund, and Co-opPlus decided to focus on the development of a vehicle for channeling local investment in renewable energy projects through a cooperative membership program.

\subsection{Task 2: Assessment and Evaluation of Education and Outreach Materials} In Task 2, Co-opPlus:

- Developed education and outreach materials about the products and services assessed in Task 1

- Defined the most effective education and outreach approaches

- Conducted pilot public meetings to affirm applicability to consumer-owned cooperative businesses. 


\subsubsection{Subtask 2.1}

Co-opPlus developed and conducted a survey to identify the renewable energy products and services of most interest to consumer owners and determine their requirements for interconnection.

\subsubsection{Subtask 2.2}

Co-opPlus developed education and outreach materials tailored to the knowledge requirements of consumer-owned cooperative business organizations regarding the availability and characteristics of products and services related to renewable energy resources. To develop such materials, Co-opPlus took advantage of available materials, such as those by other entities, whenever possible. Some materials were modified to meet the specific needs of cooperative members and consumer owners.

\subsubsection{Subtask 2.3}

Co-opPlus developed and conducted several pilot public meetings to test and evaluate the education and outreach materials and establish a baseline of the knowledge requirements of consumer-owned cooperative businesses in the Western Massachusetts region. Based on the results, Co-opPlus refined the education and outreach materials related to the distribution of "green" energy from renewable energy resources.

\subsection{Task 3: Development of an Onsite Distributed Generation Implementation Plan for a Consumer-Owned Cooperative Business}

Task 3 used the results of the Co-opPlus assessment of renewable energy products and services, in general, and solar energy resources, in particular. Co-opPlus researched and developed a tactical and strategic implementation plan for renewable energy-based onsite distributed generation and applied that plan to a pilot study of onsite distributed generation from solar energy systems.

Co-opPlus researched and developed the project management and implementation tools necessary for a consumer-owned cooperative business to establish and sustain onsite distributed generation using renewable energy products and services. Co-opPlus identified, developed, and recorded the necessary steps to achieve renewable energy-based onsite distributed generation. These steps included siting, permitting, installing (including establishing contractual arrangements with certified installers), and interconnecting onsite distributed generation systems.

\subsubsection{Subtask 3.1}

The first task determined requirements related to siting, interconnecting with the power grid, and the utility serving the consumer-owned cooperative business. Co-opPlus collaborated with PV Squared and local utilities to identify, develop, and record:

- Siting and equipment requirements

- Grid effects and how they were be addressed

- Factors necessary to meet the requirements of IEEE 1547 and other standards

- Detailed cost estimates for each of the implementation steps. 


\subsubsection{Subtask 3.2}

In accordance with Co-opPlus' agreement with the Massachusetts Technology Collaborative, it initiated and conducted a pilot study of onsite distributed generation using solar energy products and services. Co-opPlus tested and evaluated the tactical and strategic implementation plan through practical application of actual installation projects. PV Squared completed the installation, permitting, and interconnection of solar energy systems for distributed generation. Co-opPlus then used the results of the pilot study to refine its onsite distributed generation implementation plan. No federal funds were used for the acquisition of equipment or property for the pilot study.

The result of Task 3 was an onsite distributed generation implementation plan that is generally replicable to solar energy installations and specifically tailored to consumer-owned cooperative businesses. The pilot study was successful in all aspects of implementation and provided a significant learning experience to build on. More than 600 members are in the pipeline for inclusion, and more than 50 are in the process of completing a system or have a completed system. The pilot study increased the number of solar electric systems in Massachusetts by more than $10 \%$.

The success of the pilot study indicated that more than one installer partner was necessary, so a second formal relationship was developed, and the process was adapted to handle collaboration with two business partners. Also, the volume of data and interactions required the transition to an electronic database for tracking and management reporting.

Some surprises came up. For example, the town of Greenfield has a network configuration for its local utility grid. This is highly unusual, so the first member-customer in the area had to exert some effort to educate and collaborate with the local utility. However, once the first system was installed, the road was paved for subsequent systems. No significant challenges in this domain are expected today.

The education required to lead potential customers through the pipeline continues to be significant, although an improvement has been achieved. The general level of knowledge in the region has increased among contractors, electricians, inspectors, and utility personnel. Given the number of systems already installed, there also are typically several systems nearby that can provide examples of what a system looks like and facilitate the assessment of aesthetic impact and other issues. In addition, more and more Web sites have detailed, wellcrafted information.

To further the triage of opportunities, Co-opPlus is considering requiring upfront payment from potential customers for at least part of the cost of a site visit. This would offset some of the costs of the development work but, more importantly, would require that potential customers "put some skin in the game" (i.e., get fully vested in the efforts to assess the feasibility of a solar system). 
Salmon Fall Land Association is an interesting example of a member customer. It has demonstrated what could be a model for residential homeowners to collaborate to save money on energy. Four households collaborated to build a small co-housing community based on sustainable energy principles. They are building four homes that go beyond ENERGY STAR standards to minimize the energy each will use. They also set up one common residential utility connection with individual submeters. Payment of the utility bill is coordinated independently among the households. This allowed significant savings through the installation and net metering of a single common solar system, rather than four individual systems.

The group installed a 600-A electricity service and had it classified by Western Massachusetts Electric Co. for a residential rate. It installed a 4-kW AC solar array to provide electricity for the four homes. The $4-\mathrm{kW}$ system was connected to the $600-\mathrm{A}$ common service. The group built a utility shed to house the inverters and meters, with space for other renewable energy resources when they become available and affordable. The 4-kW system cost $\$ 34,000$ before incentives. Four $1-\mathrm{kW}$ systems would have cost $\$ 40,000$ or more before incentives.

Salmon Fall Land Association was an "early adopter," and its system has proved a valuable demonstration site to give potential customers a first-hand impression of the components of a solar system. This proved a valuable tool for convincing customers to invest time and effort in their own education and to make the decision to install a system.

This example is captured here because it also provides a direct indication of the economic potential of aggregation. This could be a group of households or a small town that aggregate to get one service and provide their own submetering, which allows installation and net-metering of one central system. Co-opPlus intends to engage in further research on this subject.

Secondarily, other forms of volume aggregation are also recommended for further research. These include developing a standard solar "kit" that could fit $75 \%$ of interested customers, buying parts in bulk (possibly directly from manufacturers), and contracting with installers for volume installation in specific geographic areas.

Although solar electric technology has been around for many years, it is not yet a mainstream product. The pilot study provided first-hand experience of the education and individual attention to each customer that is required. However, Co-opPlus believes the development of a solar "kit" is the next step in the logical evolution of solar electric systems, and it plans to offer a product in the near future.

Task 4 was deleted from the project and, therefore, is not reported on in this report. 


\subsection{Task 5: Development of Centralized Renewable Energy Generation Fuel Production With a Plan for Cogeneration for a Consumer-Owned Cooperative Business Model}

In Task 5, Co-opPlus researched and developed a tactical and strategic implementation plan for biodiesel fuel production, including plans for co-generation, which is distributed generation. Co-opPlus is now applying the implementation plan to a pilot study of biodiesel fuel production with future cogeneration. Using the biodiesel fuel production facility as a model, Co-opPlus has researched and developed the project management and implementation tools necessary for a consumer-owned cooperative business to establish and successfully sustain renewable fuel production.

This application model will generate biodiesel fuel that can be used to run a grid-tied microturbine or other distributed power generation option - any power system compliant with the IEEE 1547 interconnection standard - to displace part of the electrical demands of the biodiesel facility. In this way, the project will be an example of combining renewable energy production with distributed generation co-generation. Co-opPlus identified, developed, and recorded the necessary steps to achieve renewable energy generation or fuel production and developed a plan for siting, permitting, installing, and interconnecting a co-generation system for the consumer-owned cooperative business model.

\subsubsection{Subtask 5.1}

In this task, Co-opPlus determined the requirements for siting the biodiesel-powered system, interconnecting with the grid, and satisfying the utility serving the consumer-owned cooperative business. Co-opPlus identified, developed, and recorded:

- Siting and equipment requirements

- Grid effects and how they will be addressed

- Factors necessary to meet the requirements of IEEE 1547 and other standards

- Cost estimates for project implementation.

\subsubsection{Subtask 5.2}

In this task, Co-opPlus initiated and conducted a pilot study of renewable fuel production. It tested and evaluated the tactical and strategic implementation plan developed through the practical application of an actual installation project.

Co-opPlus completed siting and design of a renewable fuel production plant. Permitting applications have been submitted. It used the results of this pilot study to refine the renewable fuel production implementation plan. Federal funds from NREL were not used for the acquisition of equipment or property necessary to implement the pilot study. 


\subsubsection{Subtask 5.3}

In this task, Co-opPlus evaluated renewable energy resource acquisition for renewable fuel production from a regional resource base. Co-opPlus:

- Defined strategies for resource acquisition

- Compared the viability of each strategy

- Recommended the most viable resource acquisition strategy.

The cost of recycled vegetable oil is approximately $60 \%$ of total production cost and the largest cost component of the biodiesel production process. Co-opPlus identified more than 5,000 sources of recycled vegetable oil within a 60-mile radius of Greenfield, Massachusetts, with 399 restaurants in the locally accessible four-county region.

National studies have demonstrated that about 1.1 gallons of collectable recycled vegetable oil is generated in restaurants per person in a local population per year. Because the Northeast has a population of 54.4 million people, nearly 60 million gallons of recycled vegetable oil can be collected annually. The biodiesel production facility would require 12 million gallons per year of recycled vegetable oil when it ramps up to production of 10 million gallons a year.

Co-opPlus identified the following strategies for resource acquisition:

- Direct collection from restaurants and cafeterias in the region, direct collection through independent contractors hired by the biodiesel production facility, or direct collection through farmers transporting recycled vegetable oil on return from deliveries to Boston and New York City

- Deliveries from municipal or corporate collection

- Deliveries under contract with a recycled oil collector

- Deliveries under contract with a rendering company.

\subsubsection{Direct Collection}

Co-opPlus' door-to-door survey of 97 local restaurants showed they were willing to contract for vegetable oil recycling services. Recycled vegetable oil could also be collected by independent contractors or farmers back-hauling barrels of grease from Boston and New York City. At first, Co-opPlus considered using flat bed pickup trucks or livestock or vegetable delivery trucks. They would deliver the oil to the Co-opPlus receiving station for a fixed price per gallon.

Co-opPlus initially intended to use a standard, open-topped 55-gallon drum collection system. This would allow it to obtain inexpensive, standardized containers that could be handled by one person, cleaned thoroughly, and distributed easily. Such containers are commonly used in the industry. 
The independent contractors and back-haul farmers would make agreements with restaurants, schools, and other sources of recycled vegetable oil for the collection service. These contractors would set their own price structure with customers. Generally, the cost of a drum of oil picked up was planned at around $\$ 20$. This is competitive with other service vendors in the region, which average around $\$ 38 /$ drum picked up. The independent contractors could adjust their pricing upward if they obtained a sufficient customer base. They would truck a minimum, if using a pickup truck, of six filled drums per trip to the refinery or more (approximately 20 filled drums) if they used a flatbed or livestock delivery truck. The contractors could obtain revenue from the waste generator and a fluctuating unit fee from the refinery for delivered oil. Co-opPlus assumed the biodiesel production facility would pay \$0.30-\$0.40/gallon for contaminate-free delivered oil.

Co-opPlus did not pursue this strategy for the following reasons:

- It wanted to focus its resources on producing high-quality biodiesel, not on developing a collection business.

- It was not sure this strategy could produce a dependable supply of feedstock.

- It estimated a cost of $\$ 250,000$ to construct an automated receiving line to receive, empty, and clean the 55-gallon drums.

\subsubsection{Municipal or Corporate Collection}

Municipalities or corporations could contract with the biodiesel production facility to deliver recycled oil in exchange for a $20 \%$ biodiesel blend. They would receive 0.83 gallons of biodiesel for each gallon of recycled oil at $\$ 0.35$ less than their contracted price for diesel fuel. Municipalities could make agreements with restaurants, schools, and other sources of recycled vegetable oil in the region. Corporations or other businesses that generate a large volume of recycled vegetable oil could arrange to transport their oil to the biodiesel production facility. Pick-up services average around \$38/55-gallon drum. 
Table 5. Pro Forma for a Recycled Vegetable Oil Collection Service

\begin{tabular}{|c|c|c|c|c|c|c|}
\hline \multicolumn{7}{|l|}{ Annual Estimated Revenue } \\
\hline $\begin{array}{l}\text { Gallons of Used Cooking Oil Provided } \\
\text { Equivalent } 55-\text {-Gallon Drums }\end{array}$ & & 481,928 & 602,410 & 722,892 & 963,855 & $1,204,819$ \\
\hline Collected/Month & & 730 & 913 & 1,095 & 1,460 & 1,825 \\
\hline Per-Gallon Discount for B100 & \multicolumn{6}{|c|}{$\$ 0.35$ less than contracted \#2 distillate cost } \\
\hline Petroleum Diesel (Gallons) & & $1,600,000$ & $2,000,000$ & $2,400,000$ & $3,200,000$ & $4,000,000$ \\
\hline Biodiesel (Gallons) & & $\underline{400,000}$ & $\underline{500,000}$ & $\underline{600,000}$ & $\underline{800,000}$ & $1,000,000$ \\
\hline Annual Total Gallons of Fuel B20 & & $2,000,000$ & $2,500,000$ & $3,000,000$ & $4,000,000$ & $5,000,000$ \\
\hline Annual Fuel Savings & & $\$ 140,000$ & $\$ 175,000$ & $\$ 210,000$ & $\$ 280,000$ & $\$ 350,000$ \\
\hline $\begin{array}{l}\text { Annual Collection Revenue } \\
\text { (\$/Month/Restaurant) } \\
\text { (Assumes } 2 \text { Drums/Month/Restaurant } \\
\text { Average) }\end{array}$ & $\$ 15$ & $\$ 65,717$ & $\$ 82,147$ & $\$ 98,576$ & $\$ 131,435$ & $\$ 164,294$ \\
\hline $\begin{array}{l}\text { Annual Surplus From Operations } \\
\text { (Including Depr Cost) }\end{array}$ & & $(\$ 20,456)$ & $\$ 30,973$ & $\$ 82,402$ & $\$ 185,261$ & $\$ 288,120$ \\
\hline Capital Investment Payback (Years) & & 0.00 & 7.07 & 2.66 & 1.18 & 0.76 \\
\hline
\end{tabular}

\subsubsection{Contract With Recycled Oil Collector and Rendering Companies}

Co-opPlus' biodiesel production facility could also purchase recycled vegetable oil from existing regional rendering companies or existing waste collection companies such as SalCorp, which picks up more than 75,000 gallons/week of WVO from restaurants and sells "untreated" WVO. This is the more expensive source of WVO, but the cash flow analysis shows positive values under even the worst-case scenario of purchasing mostly from these established sources.

Regional rendering companies include:

- Western Mass Rendering - Southwick, Massachusetts 25 miles from Greenfield; approximately $\$ 0.03 /$ gallon transportation cost

- Baker Commodities - North Billerica, Massachusetts, and Albany, New York 100 miles from Greenfield; approximately $\$ 0.07 /$ gallon transportation cost

- Darling International - Newark, New Jersey 150 miles from Greenfield; approximately $\$ 0.10 /$ gallon transportation cost

- Corenco - Tewksbury, Massachusetts 100 miles from Greenfield; approximately $\$ 0.07 /$ gallon transportation cost 
Waste collection companies include:

- $\quad$ SalCorp - Queens, New York

WVO from restaurants in New York City; preferred source, currently negotiating supply contract for all bulk requirements through 2007; 130 miles from Greenfield; approximately $\$ 0.07 /$ gallon transportation cost

- Corcom Commodities - Elora, Ontario

WVO from Canada; embargo on shipments of WVO from Canada expected to be lifted March 2005; proposed 3-year supply contract currently under investigation

- American Byproducts - Boston, Massachusetts

Collects fryolator grease in greater Boston area

Co-opPlus decided to contract with a small, independent collector that was not tied to a rendering operation. The renderers want to sell their rendered product, which is more expensive (\$1.30/gallon). The collection companies charge \$0.30-\$0.75/gallon.

\subsubsection{Subtask 5.4}

In this task, Co-opPlus researched the legal and accounting structures for the consumer-owned cooperative business. Co-opPlus reviewed incorporation options, including a standalone cooperative structure and cooperative ownership of a limited liability corporation. Co-opPlus:

- Identified corporate structure options

- Analyzed the pros and cons of each option

- Made a recommendation of the most appropriate structure.

This group of consumers could have legally organized as any kind of corporate entity. The group worked with several lawyers, including several that specialize in cooperative law, to analyze the options. It considered the benefits and opportunities that each of the following corporate structures provides:

- Limited liability corporation

- Cooperative

- For-profit $\mathrm{C}$ corporation

- For-profit $\mathrm{S}$ corporation

- For-profit association

- Tax-exempt nonprofit. 
Co-opPlus required that the legal structure:

- Facilitate ownership and control by the members

- Accommodate a large number of members

- Preclude taxation at both the individual and the corporate level

- Allow Co-op Power to collect member equity from many people inexpensively to invest in products and services

- Allow Co-op Power to distribute excess profits back to members.

Table 6. Comparison of Legal Structures for Group-Based Businesses

\begin{tabular}{|c|c|c|c|c|c|c|}
\hline & $\begin{array}{c}\text { Limited } \\
\text { Liability } \\
\text { Corporation }\end{array}$ & Cooperative & $\begin{array}{l}\text { For-Profit C } \\
\text { Corporation }\end{array}$ & $\begin{array}{l}\text { For-Profit S } \\
\text { Corporation }\end{array}$ & $\begin{array}{c}\text { Nonprofit } \\
\text { Association }\end{array}$ & $\begin{array}{c}\text { Tax- } \\
\text { Exempt } \\
\text { Nonprofit }\end{array}$ \\
\hline $\begin{array}{l}\text { Easy for } \\
\text { members to } \\
\text { own and } \\
\text { control? }\end{array}$ & Yes & Yes & No & No & No & No \\
\hline $\begin{array}{l}\text { Number of } \\
\text { members }\end{array}$ & $\begin{array}{l}\text { Best for } 15 \\
\text { or fewer }\end{array}$ & Unlimited & Unlimited & Unlimited & Unlimited & Unlimited \\
\hline $\begin{array}{l}\text { Taxation of } \\
\text { profits at } \\
\text { corporate and } \\
\text { individual } \\
\text { levels? }\end{array}$ & No & No & Yes & $\begin{array}{l}\text { Generally, } \\
\text { no }\end{array}$ & No & No \\
\hline $\begin{array}{l}\text { Can many } \\
\text { members } \\
\text { contribute } \\
\$ 1,000 \text { and } \\
\text { receive a } \\
\text { share of the } \\
\text { profits } \\
\text { inexpensively? }\end{array}$ & Yes & Yes & No & No & No & No \\
\hline
\end{tabular}

The primary benefits of the cooperative structure are:

1. Capital formation

As a group of consumers seeking to secure access to sustainable energy resources, the cooperative is the only structure that would allow Co-op Power to raise capital from its members inexpensively. A nonprofit corporation would have required members to make donations and would not have allowed return of benefit to members because all benefits in a nonprofit must stay within the nonprofit. A for-profit corporation would have required registration of a securities offering (at a cost of $\$ 300,000$ or more) or a preferred-share offering to a small number of large investors (at a cost of $\$ 10,000$ $\$ 15,000)$. 
There is a long history in the United States of consumers using a cooperative structure to pool resources to secure access to products and services.

- Electricity generation, transmission, and distribution

More than 37 million consumers in the United States own the 900 rural electric cooperatives that provide electricity to more than $75 \%$ of the landmass.

Member equity in these cooperatives is used to build generation, transmission, and distribution cooperatives that provide low-cost electricity to the members.

- Wholesale food distribution

Consumers in the United States own more than 500 grocery cooperatives that provide food for their members. Member equity in these cooperatives has been used to build regional food distribution warehouses to help the cooperatives secure access to quality foods at affordable prices.

- Wholesale financial services

More than 80 million people are members of the 10,000 credit unions in the United States. Credit unions are cooperatively owned financial institutions. They have built a significant infrastructure to provide affordable financial products and services.

- Phone service infrastructure

Two hundred seventy telephone cooperatives provide phone service to more than 2 million people. Member equity is used to build and maintain phone lines and phone service infrastructure.

- Housing

Six thousand four hundred housing cooperatives provide housing to more than 1.5 million households. Member equity is used to build and maintain housing.

2. Marketing, market penetration, and member communication A significant body of market research has documented consumer attitudes toward cooperatives and locally owned businesses. Consumers aware of cooperatives believe cooperatives are a more trustworthy source of information, have their interests in mind, and deliver quality products and services at affordable prices. In studies repeated across industry sectors, approximately $90 \%$ of consumers report they would prefer competitively priced products if they bore the co-op label. ${ }^{1}$

\footnotetext{
${ }^{1}$ Gallup Poll, 1994; Penn \& Schoen Survey, 1996; MACRO International, 1999.
} 


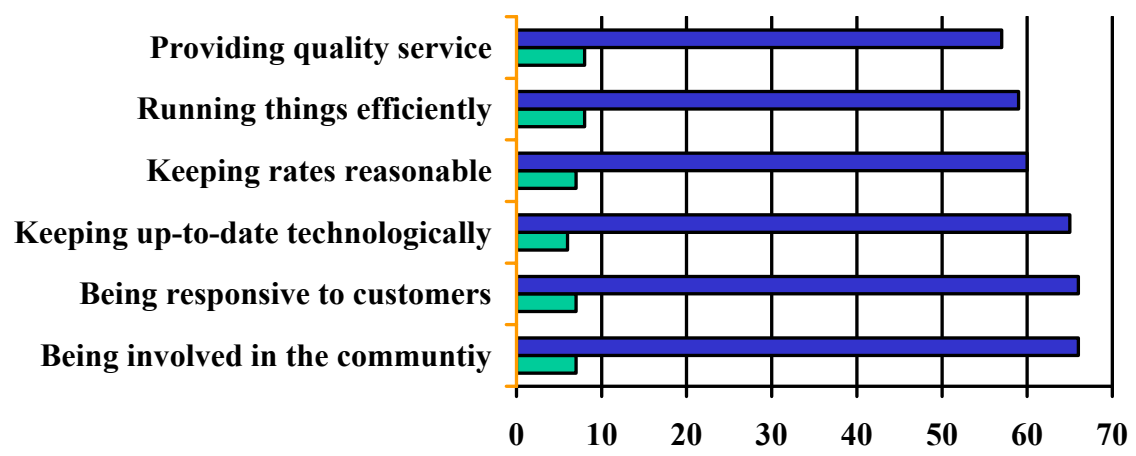

A Co-op does a: $\square$ Worse Job $\square$ Better Job

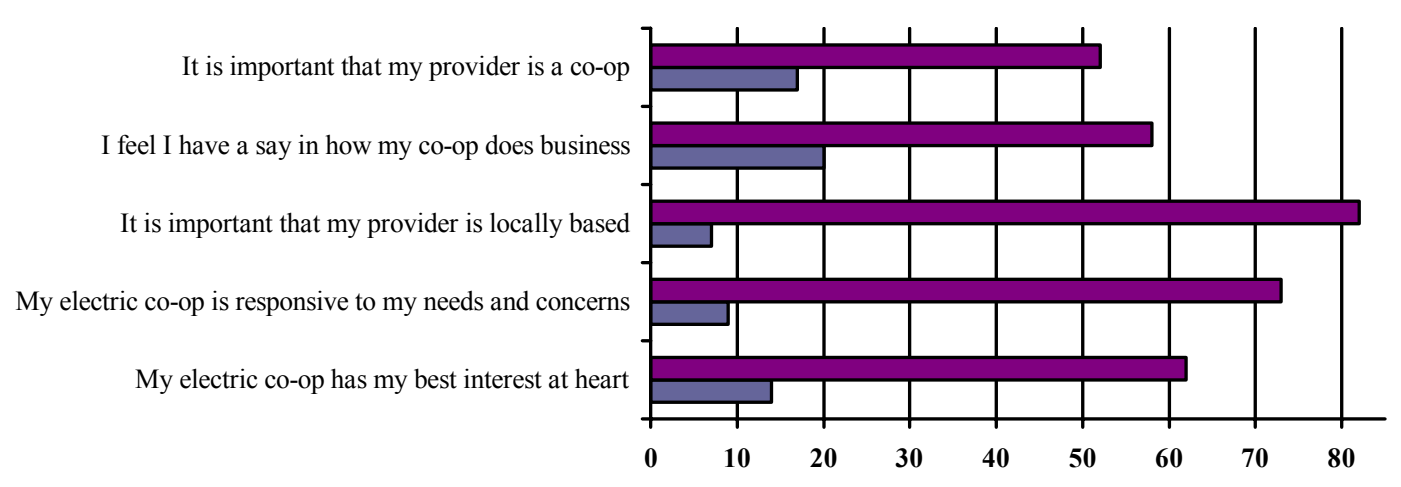

$\square$ Disagree $\square$ Agree

Figure 2. Touchstone Energy market consumer research results ${ }^{2}$

Rural electric cooperatives have developed a common brand called Touchstone Energy. This organization has conducted extensive market research over the past 5 years and found that consumers have confidence in its cooperatives. Touchstone Energy Services also discovered that consumers believe it is important that their energy provider is a locally owned cooperative that is responsive to their needs.

The second chart shows that $82 \%$ of respondents indicated it was important that their energy provider is locally based. This finding has been repeated in many studies and shows consumers are interested in purchasing products from businesses in which decisions are made nearby, customer service representatives understand their area, profits are distributed within the community, and the company contributes back to the local community.

\footnotetext{
${ }^{2}$ Touchstone Energy Services, 1999.
} 
The sustainable energy industry is still in its infancy. People are unfamiliar with biodiesel as a fuel for home heating and transportation. Renewable energy certificates appear to some to be a shell game. People find renewable energy installations complex, expensive, and daunting. A cooperative dedicated to their needs can serve effectively as a source of trustworthy information by assisting consumers in making the transition to new energy resources.

The consumer owners of this energy cooperative are focused on securing regional access to sustainable energy products and services; therefore, the business is focused on product development and sound financial health rather than on maximum return on profit. Because consumers understand that this business structure focuses on their needs, they have more trust in the business. With increased trust, the cooperative will be able to open the market for sustainable energy products and services more successfully and less expensively than alternative business structures. Marketing and market development efforts will be carried out as member education and membership development programs and will use volunteers and low-cost materials.

Co-op Power incorporated as a cooperative because it is the only legal structure that met its criteria. It provides a structure that is easy for members to own and control, allows for an unlimited number of members, is taxed either at the corporate or individual level but not both, and allows members to invest $\$ 975$ in member equity and receive a share of the excess profits without requiring an expensive securities filing.

Co-op Power incorporated the biodiesel production facility as a limited liability company to bring in the outside capital needed.

\subsubsection{Subtask 5.4}

In this task, Co-opPlus researched renewable fuel production location and building options. It:

- Researched location and building options

- Developed criteria for location and building selection

- Made a recommendation for the most appropriate location/building.

The ultimate biorefinery site must meet these basic requirements:

- A minimum of $10,000 \mathrm{ft}^{2}$ of production space and $1,000 \mathrm{ft}^{2}$ of office space

- A production space expandable to $20,000 \mathrm{ft}^{2}$

- A location in the four-county area (Franklin, Hampshire, Berkshire, and Hamden) of Western Massachusetts

- Two loading docks

- Easy access for tractor trailers and oil trucks

- City water (a minimum 12-inch water main) and sewage

- 480-V three-phase power

- Industrial zoning

- A satisfactory 21-E environmental assessment. 
Other site considerations include:

- Rail spur availability

- Existing boilers

- State and local economic development assistance qualification

- Existing storage tanks (that are adaptable for oil and grease).

The possible locations were:

- Wells Street Furniture Manufacturing Facility

- Turners Falls Industrial Park

- Greenfield Industrial Park

- Deerfield Oil Dealer Site

- Industrial zone lots in Whately, Hatfield, and North Hatfield.

Only two of these sites (The Wells Street site and the Greenfield Industrial Park) had sewer access. The Wells Street site cost $\$ 500,000$; the Greenfield Industrial Park cost $\$ 80,000$ for the site and $\$ 130,000$ for site improvements (ledge removal). The biodiesel production facility is planned for the Greenfield Industrial Park property.

The result of Task 5 is a biodiesel fuel production implementation plan-which includes a plan for the acquisition of resources, a legal structure recommendation, and location/building selection criteria - that is generally replicable for a renewable fuel production facility and specifically tailored to the requirements of a consumer-owned cooperative business. An executive summary of the current implementation plan follows.

\subsection{Implementation Plan Summary}

Biodiesel is the rising star of the alternative transportation fuel industry. It is a renewable fuel with significant environmental benefits. It is safe and biodegradable, and it reduces air pollutants such as soot, particulates, carbon monoxide, hydrocarbons, and carcinogens. A 1998 NREL study concluded that the use of 100\% biodiesel reduces carbon dioxide emissions by more than $75 \%$ over petroleum diesel and a blend of $20 \%$ biodiesel reduces carbon dioxide emissions by $15 \%$. The stress on landfills and incinerators is reduced also because recycled vegetable oil is removed from the waste stream. In addition, using biodiesel reduces dependence on foreign oil and supports community and regional economies. Because of its recycled materials, clean air performance, impressive net energy balance compared with other fuels, and aesthetic cache, the demand for biodiesel is rising in the Northeast faster than it can be supplied.

\subsubsection{Plant Production Capacity and Sales Growth}

A 4.5 million-gallon biodiesel production facility that uses recycled vegetable oil as the primary feedstock will be built in Greenfield, Massachusetts. Sales are expected to reach $\$ 10.9$ million in 2007 and rise to $\$ 24.7$ million in 2008 with a production capacity expansion to 10 million gallons/year. 
The planned production start-up is February 2006. Production will then ramp up through the addition of a third shift in September 2006 and an additional production line in January 2008 to reach $85 \%$ capacity of 8.5 million gallons/year production.

\subsubsection{Financing}

The biodiesel production facility initially requires approximately $\$ 5.53$ million in financing. The project has assumed an initial financing debt and equity structure of $50.3 \%$ debt and $49.7 \%$ equity. The initial equity $(\$ 750,000)$ is from Co-op Power. The balance of the equity ( $\$ 2$ million) will come from qualified private investors, some of whom have already been identified. Debt financing includes a business loan of $\$ 863,091$, a real estate loan of $\$ 1,266,110$, and working capital of $\$ 655,000$. The planned 2008 expansion to 10 million gallons/year will require an additional $\$ 5.5$ million in capital, $\$ 4.1$ million in long-term debt, and $\$ 1.4$ million in equity.

\subsubsection{Competition}

Although the Department of Energy projects U.S. biodiesel production to grow by nearly $40 \%$ this year, the biodiesel production facility will be one of the first operational production systems within 300 miles at the time of its projected opening. Existing or soon-to-be opened biodiesel production facilities are located hundreds of miles west or south of the proposed location - in Cincinnati, Ohio; at Griffin Industries in Kentucky; at the World Energy site in Lakeland, Florida; and at the Mid-Atlantic Biodiesel Co. facility in Clayton, Delaware. The biodiesel production facility will have a slight cost advantage for 1 or 2 years at most. The biodiesel production facility will have this advantage because of its low-cost feedstock for the first 3 years. To stay competitive, it will reduce its costs and increase its efficiency by increasing its production capacity to 10 million gallons/year by October 2008 .

\subsubsection{Recycled Vegetable Oil - Primary Feedstock}

The biodiesel production facility has a highly competitive product because recycled vegetable oil is a lower-cost feedstock than virgin oil. It has executed a supply agreement with a waste vegetable oil collector that will provide $100 \%$ of the first 2 years of used vegetable oil and $75 \%$ of the expanded (10 million gal/year) requirements in 2008 . The used vegetable oil will be collected from restaurants, cafeterias, and other food processors in the New York City and Philadelphia areas. The cost of the used vegetable oil feedstock is a primary determinant of the profitability of the operation. The recycled vegetable oil supply agreement ensures a competitive production cost.

\subsubsection{Wholesale Sales}

The recycled base material will appeal to energy- and resource conservation-aware customers. One of the challenges will be to address concerns about the use of recycled vegetable oilbased biodiesel in the Northern climate. Concerns arise from the use of $100 \%$ biodiesel in cold weather. The strategy to focus regional sales on $2 \%-5 \%$ blends will help minimize any negativity directed at a recycled vegetable oil-based product. 
A sales agreement for three-fourths of the anticipated production for the first 3 years has been negotiated with a national distributor. The remaining quarter of anticipated production will be sold to heating oil dealers and diesel fuel distributors in the region, which will, in turn, blend their product with conventional No. 2 distillate $(2 \%-3 \%$ blends) as a product differentiator.

\subsubsection{Technology}

The process technology for biodiesel production is well established; the production of methyl esters has been happening for more than 150 years. The biodiesel production facility has selected Rocky Mountain Biodiesel Consulting to design a batch-type process that uses recycled vegetable oil. Rocky Mountain Biodiesel Consulting has partnered with Process Technology Associates for this project. The team has more than 17 years of biodiesel experience in design and engineering, construction, production, management, start-up, shake down, problem solving, analytical support, feedstock analysis, marketing, research, regulatory analysis, feasibility assessment, business planning, and other strategic business activities. The team will provide custom biodiesel technology design and turnkey development as well as construction oversight and start-up support. In addition, it has engaged the services of a local firm that is experienced in the construction of chemical plants to provide construction and construction management services.

\subsubsection{Glycerin}

The biodiesel production facility is looking for outlets to use the glycerin byproduct from its biodiesel manufacturing. It has not yet entered into any agreements, primarily because the chemical makeup of the glycerin that will be produced from the used cooking oil-based biodiesel manufacturing process is not known. Glycerin produced as a biodiesel byproduct may contain impurities, some of which can affect its value. Once the production facility is up and running and there is a better understanding of the quality of glycerin produced, the facility will be able to better access the opportunities for sale of that byproduct.

There have been preliminary discussions with two parties regarding the glycerin byproduct. However, a deal cannot be finalized until the chemical composition of the glycerin byproduct is known.

\subsubsection{Location}

The biodiesel production facility has negotiated a purchase and sale agreement for a 25 -acre lot in the Greenfield Industrial Park for \$80,000. Five acres are "buildable;" 20 are protected wetland. The town of Greenfield has been helpful in getting the facility set up and moving through the permitting process. No blocks are anticipated because the industrial park has been established to support businesses such as the biodiesel production facility. 


\subsubsection{Management}

Strong management is key to any start-up venture. The biodiesel production facility has hired a president and chief executive officer who holds a Master of Business Administration in finance and an engineering degree. He brings extensive experience in renewable energy, manufacturing, and start-up business management. Shaine Tyson and Wes Berry of Rocky Mountain Biodiesel are providing the core expertise in biodiesel production. They will design and oversee the installation of the production line. Ms. Tyson and Mr. Berry bring extensive, successful national biodiesel expertise. A production manager and plant manager will be hired once capital has been secured. The production manager will have extensive biodiesel production experience.

The board of managers currently includes the chief executive officer plus five representatives from Co-op Power, the majority owner of the biodiesel production facility.

\subsubsection{Co-Generation}

The biodiesel production facility plans to build a co-generation plant to generate electricity in January 2008.

\subsubsection{Conclusion}

The biodiesel production facility is poised to provide an essential renewable energy product for the Northeastern United States with a significant margin. The risks have been identified and addressed. Being the first plant up and running in the region and a strong cost advantage will ensure the biodiesel production facility performs well in the early years. The planned expansion to 10 million gallons/year will help the biodiesel production facility maintain a competitive position in the marketplace by lowering its cost of production.

The technology plan allows the biodiesel production facility to build in the highestperforming production line components and take advantage of low-cost, basic used equipment. A 5 million-gallon/year plant in Delaware is being built for $\$ 10$ million. This 4.5 million-gallon/year plant is being built for $\$ 5.5$ million dollars. This significant difference in capital expenditures should ensure the plant's long-term financial viability.

The board has a great deal of confidence in the management. The chief executive officer has proved his ability to launch successful businesses, build successful manufacturing lines, and communicate effectively about the value of renewable energy. Ms. Tyson and Mr. Berry have proved their ability to get plants up, running, and producing quality biodiesel.

Several vendors have offered to purchase $100 \%$ of the biodiesel production facility's planned production. Although securing a sales contract to date for only $75 \%$ of output does leave some risk on the table, it also allow the biodiesel production facility to build direct relationships with the home heating oil and diesel distributors in the region and earn slightly higher margins - both essential for ongoing business success.

The biodiesel production facility is now reaching out to potential investors to secure the $\$ 2$ million in equity required for launch by the end of October 2005. Once this is secured, the biodiesel production facility will break ground for this valuable venture. 
Appendix A. Business Plan 
A-ii 


\section{Table of Contents}

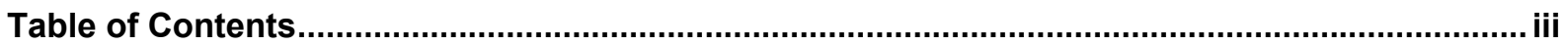

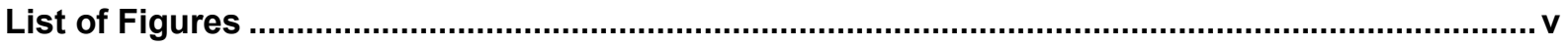

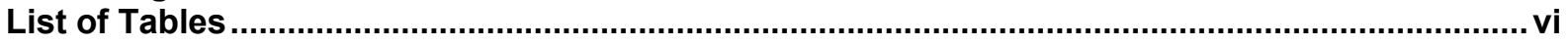

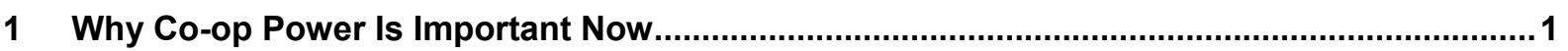

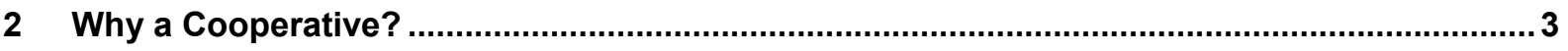

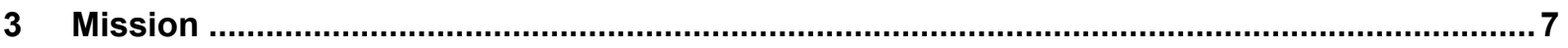

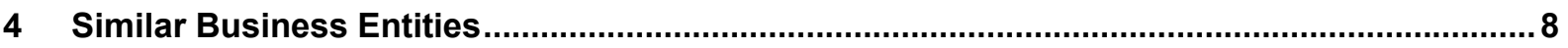

4.1 Other Consumer-Owned Cooperatives ........................................................ 8

4.2 Consumer Purchasing Groups .................................................................... 8

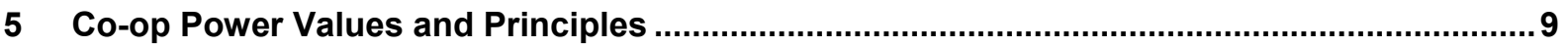

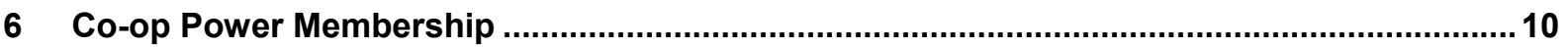

6.1 Membership Profile........................................................................................... 10

6.2 Membership Qualifications........................................................................... 10

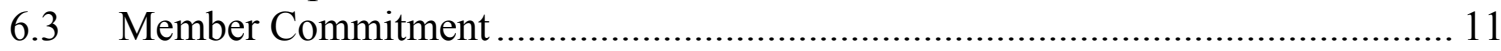

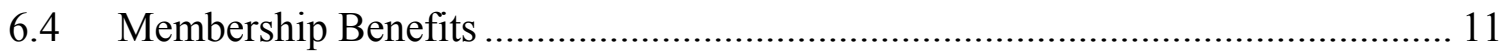

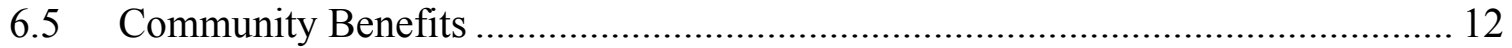

6.6 Member Risks ..................................................................................... 12

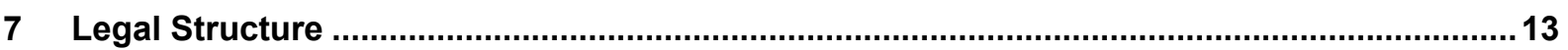

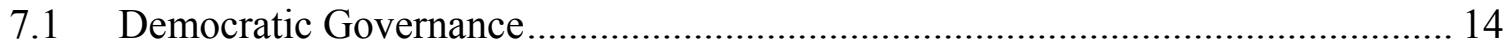

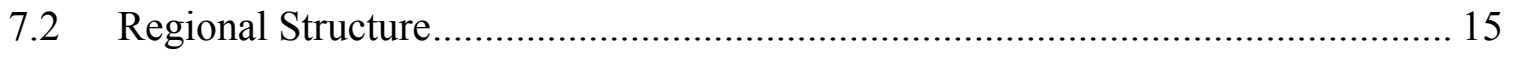

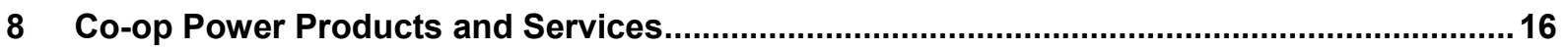

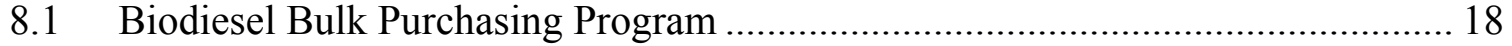

8.2 Biofuel Product Program ................................................................................... 19

8.3 Renewable Energy Certificate Program............................................................... 19

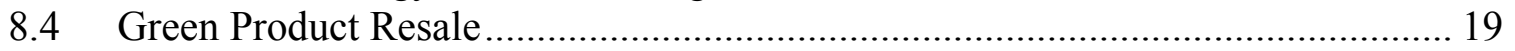

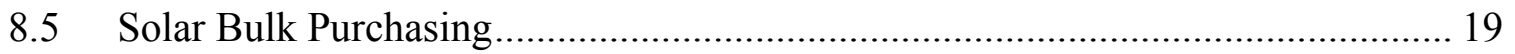

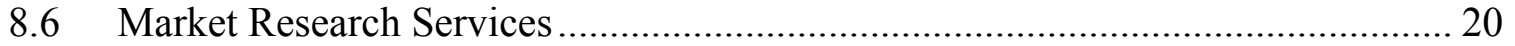

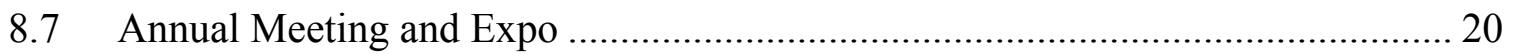

8.8 Innovative Volunteer Programs ........................................................................ 20

8.9 Sustainable Energy Education and Public Policy Advocacy ............................... 20

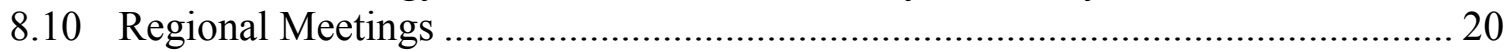

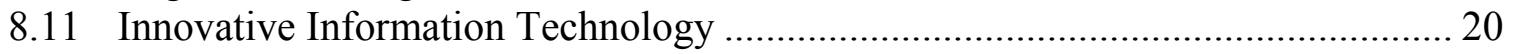

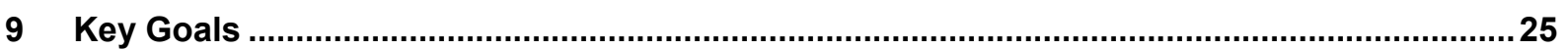

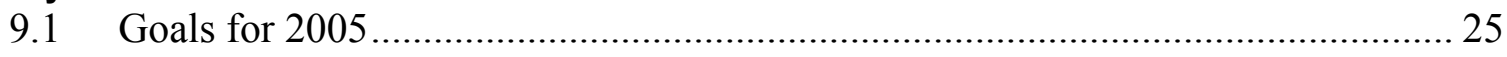

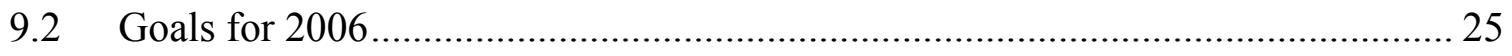

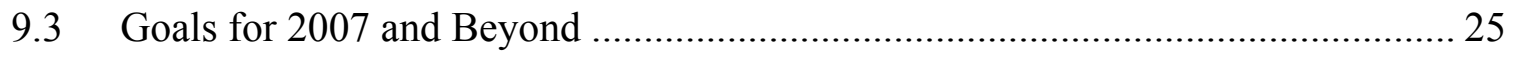

10 How Co-op Power Will Benefit the Biodiesel Production Facility .........................................26 


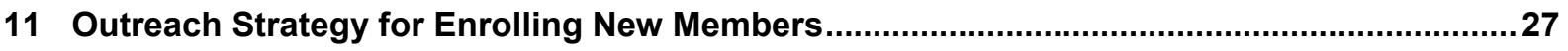

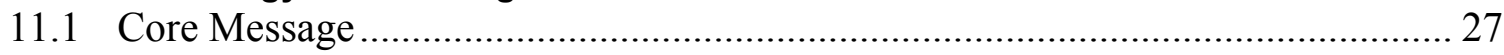

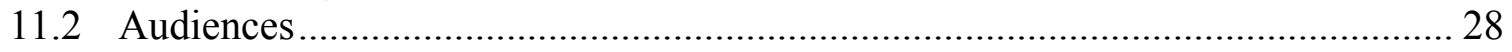

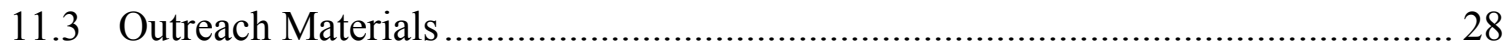

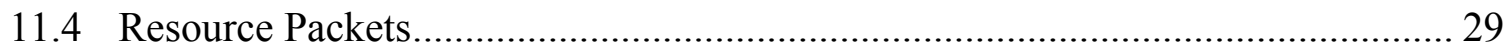

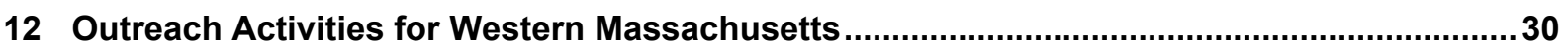

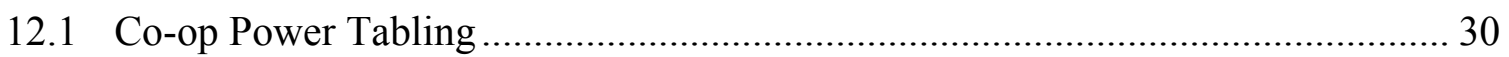

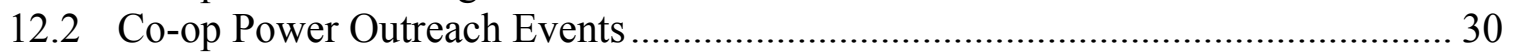

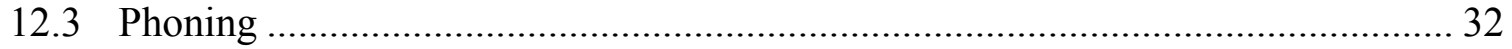

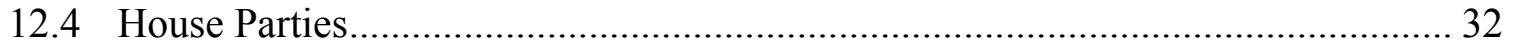

12.5 Presentations at Churches, Synagogues, and Other Religious Organizations ....... 32

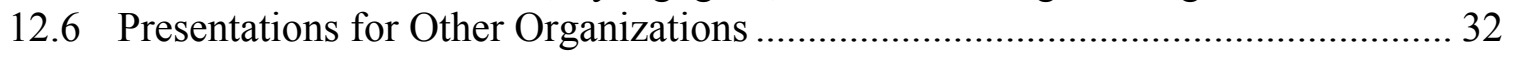

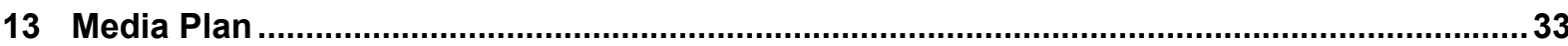

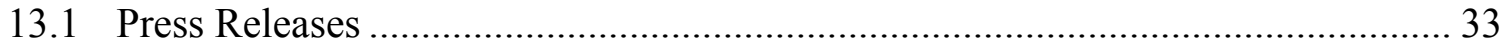

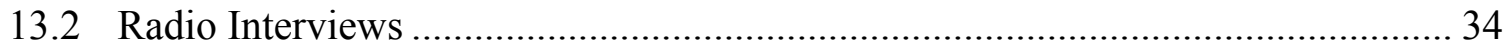

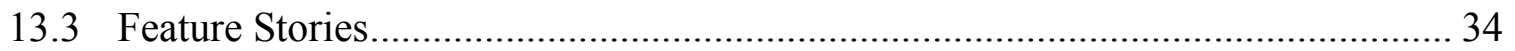

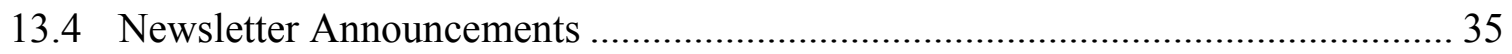

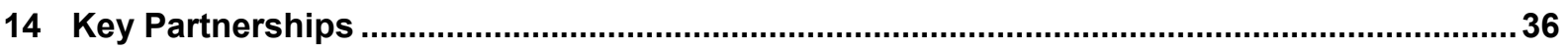

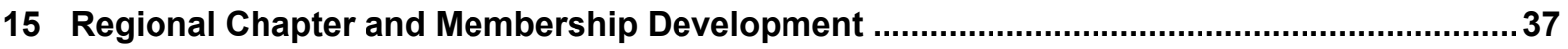

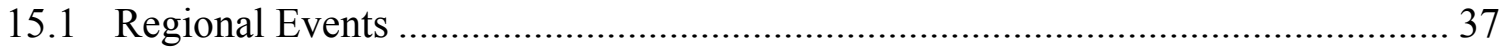

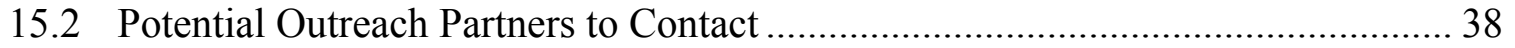

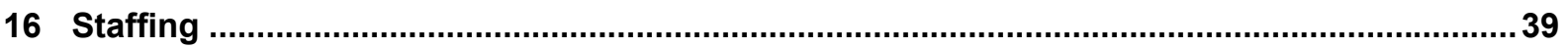

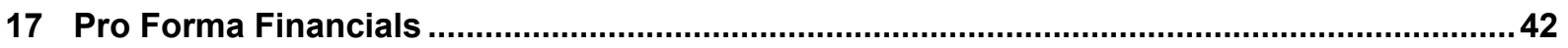

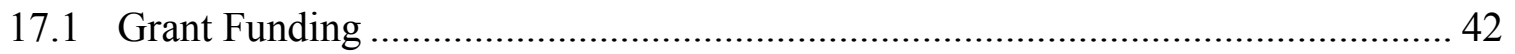

17.2 Pro Forma Income Statement ....................................................................... 42

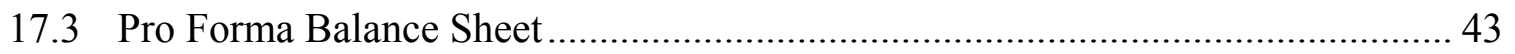

17.4 Pro Forma Member and Community Benefits ................................................ 44

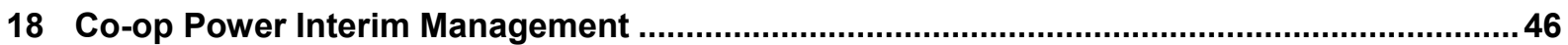

18.1 Lynn Benander, Interim Manager, Co-op Power.................................................. 46

18.2 Christian Lagier, Interim Manager, Co-op Power ............................................. 46

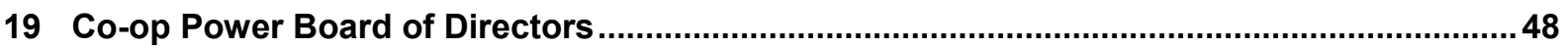




\section{List of Figures}

Figure 1. Touchstone Energy market consumer research results..................................... 5

Figure 2. Relationship between Co-op Power and Northeast Biodiesel Co. ........................ 13

Figure 3. Conceptual graphic outline of Co-op Power home page ........................................ 22 


\section{List of Tables}

Table 1. Comparison of Legal Structures for Group-Based Businesses................................... 3

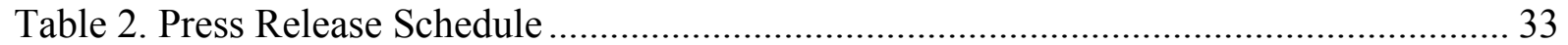

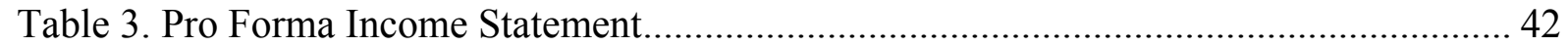

Table 4. Pro Forma Balance Sheet....................................................................................... 43

Table 5. Pro Forma Member and Community Benefits ........................................................... 44 


\section{Why Co-op Power Is Important Now}

Co-op Power is a grassroots vehicle to counter political and social trends that compromise the environment and economy. Locally owned group-based businesses can anchor capital and build community in ways few other business structures can.

To address the energy needs of the Northeast, Co-op Power is developing renewable energy resources. The first project is a biodiesel production facility that uses recycled vegetable oil to make a regionally produced, regionally owned renewable fuel for home heating and transportation. Co-op Power will also support community wind projects to provide regionally produced, regionally owned renewable energy-based electricity.

Next, Co-op Power will build an online infrastructure with which members can purchase energy products and services though bulk purchasing discounts negotiated by the cooperative. Products and services will include biodiesel for home heating and transportation, diesel vehicle leases, green electricity certificates, solar energy installations, waste oil furnaces, and energy-efficient doors and windows.

To anchor capital in the Northeast, Co-op Power is developing renewable energy resources that are owned by a large group of people who live in the region. If one person or a small group of people owned these resources, they would be free to cash them in when they stood to profit. By retaining majority ownership of these businesses, Co-op Power is more likely to ensure the jobs, capital, and renewable energy resources continue to benefit the region.

To develop and retain majority ownership of these businesses, Co-op Power must amass significant capital. To that end, the board and members have established that each member will pay $\$ 975$ for a membership share.

This business plan shows how Co-op Power plans to address the energy needs of the region, root capital in area towns and cities, and build environmentally and economically sustainable communities.

To build environmentally and economically sustainable communities, Co-op Power must educate and organize people in the region to use less energy, use renewable and regionally produced energy, and vote with their dollars for democratically owned, group-based businesses that permanently anchor capital in the region.

Residents of the region are interested in developing renewable energy products and services. A 2002 survey, conducted by Opinion Dynamics, of 125 adults in Western Massachusetts found that $91 \%$ favored increased use of renewable energy. In addition, 52\% said they would pay more for renewable energy, and 33\% of these said they would pay $\$ 15$ or more per month for $100 \%$ renewable electricity. Finally, $76 \%$ favored the idea of consumer aggregation organizations buying "green" or renewably generated power less expensively. 
Co-op Power will manage a significant ownership stake in the biodiesel production facility, oversee investments in community wind power, provide consumer-members with sustainable energy resources, and make available resources for a vibrant online community. This business plan describes how Co-op Power will become a successful and financially viable organization, launch sustainable energy projects and initiatives, secure membership access to renewable energy products and services, achieve environmental goals, educate the public, and support local communities in the region. 


\section{Why a Cooperative?}

This group of consumers could have legally organized as any kind of corporate entity. The group worked with several lawyers, including some that specialize in cooperative law, to analyze options. It considered the benefits and opportunities that each of the following corporate structures provides:

- Limited liability corporation

- Cooperative

- For-profit C corporation

- For-profit $\mathrm{S}$ corporation

- For-profit association

- Tax-exempt nonprofit.

Co-opPlus required that the legal structure:

- Facilitate ownership and control by the members

- Accommodate a large number of members

- Preclude taxation at both the individual and corporate levels

- Allow Co-op Power to collect member equity from many people inexpensively to invest in products and services

- Allow Co-op Power to distribute excess profits back to members.

Table 1. Comparison of Legal Structures for Group-Based Businesses

\begin{tabular}{|c|c|c|c|c|c|c|}
\hline & $\begin{array}{c}\text { Limited } \\
\text { Liability } \\
\text { Corporation }\end{array}$ & Cooperative & $\begin{array}{l}\text { For-Profit C } \\
\text { Corporation }\end{array}$ & $\begin{array}{l}\text { For-Profit S } \\
\text { Corporation }\end{array}$ & $\begin{array}{c}\text { Nonprofit } \\
\text { Association }\end{array}$ & $\begin{array}{c}\text { Tax- } \\
\text { Exempt } \\
\text { Nonprofit } \\
\end{array}$ \\
\hline $\begin{array}{l}\text { Easy for } \\
\text { members to } \\
\text { own and } \\
\text { control? }\end{array}$ & Yes & Yes & No & No & No & No \\
\hline $\begin{array}{l}\text { Number of } \\
\text { members }\end{array}$ & $\begin{array}{l}\text { Best for } 15 \\
\text { or fewer }\end{array}$ & Unlimited & Unlimited & Unlimited & Unlimited & Unlimited \\
\hline $\begin{array}{l}\text { Taxation of } \\
\text { profits at } \\
\text { corporate and } \\
\text { individual } \\
\text { levels? }\end{array}$ & No & No & Yes & $\begin{array}{l}\text { Generally, } \\
\text { no }\end{array}$ & No & No \\
\hline $\begin{array}{l}\text { Can many } \\
\text { members } \\
\text { contribute } \\
\$ 1,000 \text { and } \\
\text { receive a } \\
\text { share of the } \\
\text { profits } \\
\text { inexpensively? }\end{array}$ & Yes & Yes & No & No & No & No \\
\hline
\end{tabular}


The primary benefits of the cooperative structure are:

1. Capital formation

For a group of consumers seeking to secure access to sustainable energy resources, the cooperative is the only structure that would allow Co-op Power to raise capital from its members inexpensively. A nonprofit corporation would have required members to make donations and would not have allowed return of benefit to members because all benefits in a nonprofit must stay within the nonprofit. A forprofit corporation would have required registration of a securities offering (at a cost of $\$ 300,000$ or more) or a preferred-share offering to a small number of large investors (at a cost of $\$ 10,000-\$ 15,000$ ).

There is a long history in the United States of consumers using a cooperative structure to pool resources to secure access to products and services.

- Electricity generation, transmission, and distribution More than 37 million consumers in the United States own the 900 rural electric cooperatives that provide electricity to more than $75 \%$ of the landmass.

Member equity in these cooperatives is used to build generation, transmission, and distribution cooperatives that provide low-cost electricity to the members.

- Wholesale food distribution

Consumers in the United States own more than 500 grocery cooperatives that provide food for their members. Member equity in these cooperatives has been used to build regional food distribution warehouses to help the cooperatives secure access to quality foods at affordable prices.

- Wholesale financial services

More than 80 million people are members of the 10,000 credit unions in the United States. Credit unions are cooperatively owned financial institutions. They have built a significant infrastructure to provide affordable financial products and services.

- Phone service infrastructure

Two hundred seventy telephone cooperatives provide phone service to more than 2 million people. Member equity is used to build and maintain phone lines and phone service infrastructure.

- Housing

Six thousand four hundred housing cooperatives provide housing to more than 1.5 million households. Member equity is used to build and maintain housing. 
2. Marketing, market penetration, and member communication A significant body of market research has documented consumer attitudes toward cooperatives and locally owned businesses. Consumers aware of cooperatives believe cooperatives are a more trustworthy source of information, have their interests in mind, and deliver quality products and services at affordable prices. In studies repeated across industry sectors, approximately $90 \%$ of consumers report they would prefer competitively priced products if they bore the co-op label. ${ }^{1}$

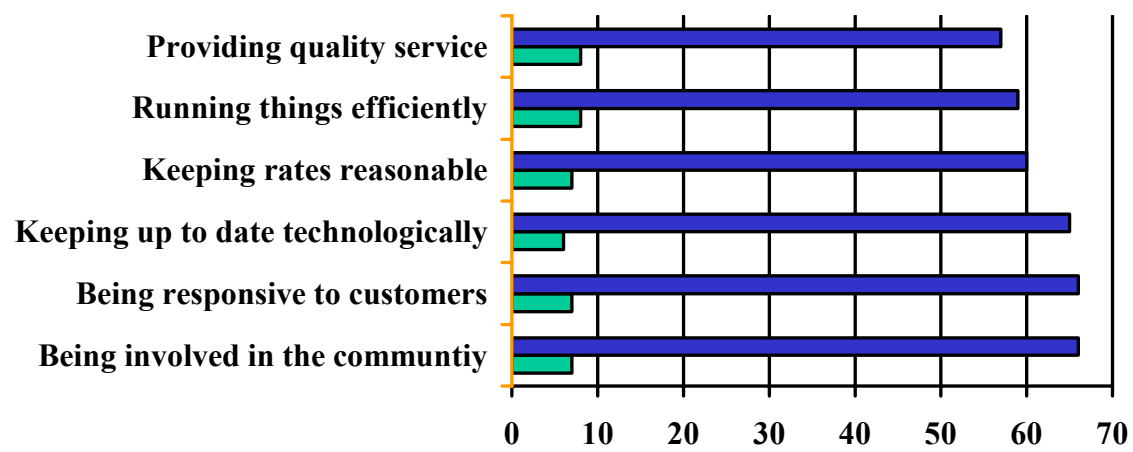

A Co-op does a: $\square$ Worse Job $\square$ Better Job

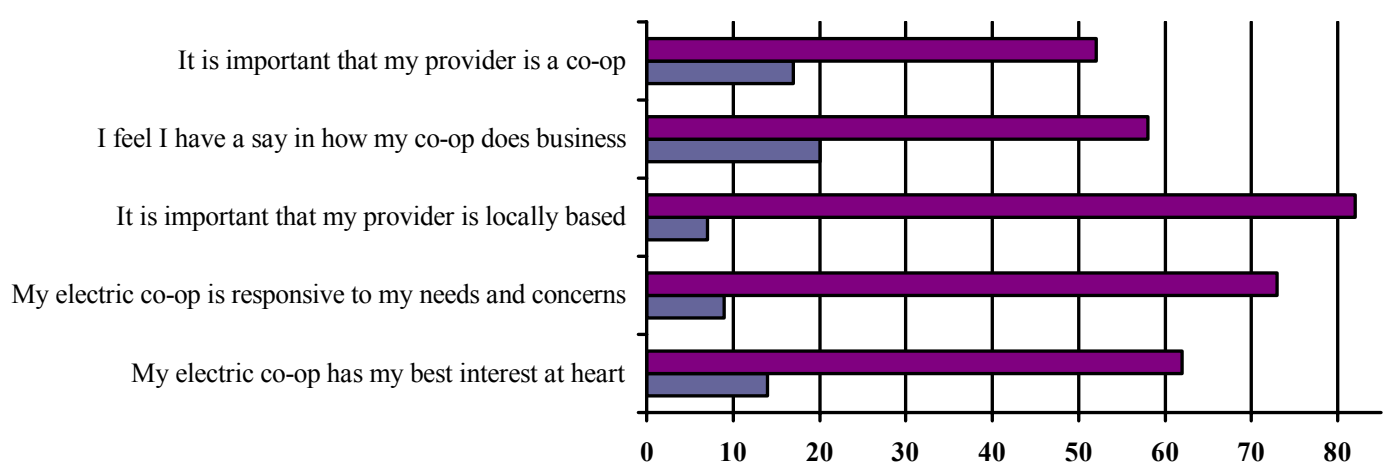

$\square$ Disagree $\square$ Agree

Figure 1. Touchstone Energy market consumer research results ${ }^{2}$

Rural electric cooperatives have developed a common brand called Touchstone Energy. It has conducted extensive market research over the past 5 years and has found that consumers have confidence in its cooperatives. Touchstone Energy Services also discovered that consumers believe it is important that their energy provider is a locally owned cooperative that is responsive to their needs.

\footnotetext{
${ }^{1}$ Gallup Poll, 1994; Penn \& Schoen Survey, 1996; MACRO International, 1999.

${ }^{2}$ Touchstone Energy Services, 1999.
} 
The second chart shows that $82 \%$ of respondents indicated it was important that their energy provider be locally based. This finding has been repeated in many studies and shows consumers are interested in purchasing products from businesses in which decisions are made nearby, customer service representatives understand their area, profits are distributed within the community, and the company contributes back to the local community.

The sustainable energy industry is still in its infancy. People are unfamiliar with biodiesel as a fuel for home heating and transportation. Renewable energy certificates (RECs) appear to some to be a shell game. People find renewable energy installations complex, expensive, and daunting. A cooperative dedicated to their needs can serve effectively as a source of trustworthy information by assisting consumers in making the transition to new energy resources.

The consumer owners of this energy cooperative are focused on securing regional access to sustainable energy products and services; therefore, the business is focused on product development and sound financial health rather than on maximum return on profit. Because consumers understand that this business structure focuses on their needs, they have more trust in the business. With increased trust, the cooperative will be able to open the market for sustainable energy products and services more successfully and less expensively than alternative business structures. Marketing and market development efforts will be carried out as member education and membership development programs and will use volunteers and low-cost materials.

Co-op Power incorporated as a cooperative because it is the only legal structure that met its criteria. It provides a structure that is easy for members to own and control, allows for an unlimited number of members, is taxed either at the corporate or individual level but not both, and allows members to invest $\$ 975$ in member equity and receive a share of the excess profits without requiring an expensive securities filing. 


\section{Mission}

Co-op Power is a consumer-owned cooperative organized to create and maintain an economically, environmentally, and socially sustainable energy future. It is locally rooted and responsive to the needs of its members and communities across the Northeast. Co-op Power harnesses the buying power of its members to secure access to products and services that reduce dependence on foreign oil, are environmentally sustainable, and benefit the local economy.

Co-op Power performs the following core functions:

1. Bulk purchasing programs and business development activities

to secure access to renewable energy and energy efficiency products and services with economic benefit for members

2. Online and in-person exchanges

through which members share experiences, collaborate, access resources, and build consensus on co-op action

\section{Market research}

to provide feedback to manufacturers and installers to support development and introduction of new energy products and services

4. Sustainable energy education, public policy advocacy, volunteer programs, and community building initiatives. 


\section{$4 \quad$ Similar Business Entities}

Co-op Power is a consumer-owned cooperative. Its members are the people that use the products and services it sells. The consumer-members own and control the business. They contribute the equity required, benefit from the business activities, and share in the profits.

The following sections provide examples of organizations that have elements similar to those of Co-op Power.

\subsection{Other Consumer-Owned Cooperatives}

Credit unions, housing cooperatives, electric cooperatives, day care cooperatives, and grocery cooperatives ask members to invest in a membership share. Members purchase financial services, housing, electricity, day care, or food from the cooperative, sometimes with a member discount. Profits are distributed based on the money members spend at the cooperative (not on the money members have invested in the business). Members elect a board of directors and vote at membership meetings. The board oversees management.

Mad River Glen ski area (www.madriverglen.com) in Vermont is a unique example of a consumer-owned cooperative. The ski area has sold almost 2,000 equity shares at $\$ 1,750$ each to members of the local community. An equity share is associated with a $\$ 200$ annual purchasing requirement. Members receive a (minor) discount on annual passes and products in the ski area store. Its bylaws are similar to those of Co-op Power, although there are some points that reflect the differences between Massachusetts and Vermont cooperative law. There is no "pay back" incentive to join, but there is a strong community incentive to support a 50year-old ski resort run by the community for the community.

\subsection{Consumer Purchasing Groups}

Consumer purchasing groups give discounts to members but do not extend ownership, control, or profit sharing to members.

DirectBuy furniture (www.directbuy.com) is a business that signs on members for a significant fee, which covers its fixed costs. It then sells them consumer goods at wholesale prices. BJ's and Sam's Club require more modest annual fees and give discounts to members. 


\section{Co-op Power Values and Principles}

Co-op Power is a cooperative, which is defined as "an autonomous association of persons united voluntarily to meet their common economic, social, and cultural needs and aspirations through a jointly owned and democratically controlled enterprise."

Co-op Power is based on the values of self-help, self-responsibility, democracy, equality, equity, and solidarity. In the tradition of the founders of the cooperative movement, Co-op Power members believe in the ethical values of honesty, openness, social responsibility, and caring for others.

Co-op Power uses the following seven principles from the International Cooperative Alliance as guidelines for putting its values into practice:

- First principle: Voluntary and open membership Cooperatives are voluntary organizations that are open to all persons able to use their services and willing to accept the responsibilities of membership, without gender, social, racial, political, or religious discrimination.

- Second principle: Democratic member control Cooperatives are democratic organizations controlled by their members, who actively participate in setting their policies and making decisions. Men and women who serve as elected representatives are accountable to the membership.

- Third principle: Member economic participation Members contribute equitably to, and democratically control, the capital of their cooperatives. Members allocate surpluses for any or all of the following purposes: developing the cooperative, by setting up reserves, part of which would be indivisible; benefiting members in proportion to their transactions with the cooperatives; and supporting other activities approved by the membership.

- Fourth principle: Autonomy and independence Cooperatives are autonomous, self-help organizations controlled by their members.

- Fifth principle: Education, training, and information Cooperatives provide education and training for their members, elected representatives, managers, and employees so they can contribute effectively to the development of the cooperative.

- Sixth principle: Cooperation among cooperatives Cooperatives serve their members most effectively and strengthen the cooperative movement by working together through local, national, regional, and international structures.

- Seventh principle: Concern for community While focusing on member needs, cooperatives work for the sustainable development of their communities through policies accepted by their members. 


\section{Co-op Power Membership}

\subsection{Membership Profile}

Co-op Power members are residential and business energy consumers in the northeastern United States who agree to support the following priorities:

1. Use less energy.

2. Use energy from renewable and other sustainable resources.

3. Strengthen the local economy.

4. Engage in sustainable energy education, public policy advocacy, and communitybuilding initiatives.

Co-op Power is being launched by Co-opPlus. Co-opPlus is a consumer cooperative based in Western Massachusetts. This cooperative has more than 1,400 members, who have indicated a strong interest in renewable energy. According to a recent survey, $40 \%$ of the members are ready to purchase solar hot water installations, $49 \%$ are ready to purchase conservation and efficiency services, and $92 \%$ are ready to purchase renewable electricity.

Co-op Power's membership comes first from Massachusetts and then from New England and New York. Across Massachusetts, consumers strongly favor the increased use of renewable energy. Market research conducted by the Massachusetts Renewable Energy Trust of the Massachusetts Technology Collaborative in February 2002 found that 90\% favored increased use of renewable energy. Eighty-seven percent believe people can reduce their reliance on fossil fuels, which contribute to air pollution and global warming. Eighty percent believe fossil fuel power plants in the United States are responsible for emitting pollutants that cause asthma. Eighty-three percent believe the country is still very dependent on foreign sources of energy and that it needs domestic energy sources.

\subsection{Membership Qualifications}

Membership is open and voluntary without gender, social, racial, political, or religious discrimination. Any person or legal entity that declares itself interested in the co-op's objectives and purpose; that agrees to be a patron of the co-op and abide fully by its articles of incorporation, bylaws, rules, and regulations; that executes a membership agreement and remits the required membership fee; and that meets such other qualifications as prescribed by the board of directors is eligible to become a member of the co-op.

The board of directors or its delegate approves applications for membership, and any application for membership may be rejected at the sole and absolute discretion of the board of directors or its delegate. Member status ("membership") is effective as of the time the membership share is purchased. 


\subsection{Member Commitment}

Members make the following commitments when they join Co-op Power:

- Members commit to supporting the co-op's mission, letting Co-op Power know when the co-op is meeting or exceeding expectations, and otherwise making suggestions.

- Members commit to participating in the democratic process, directly or by proxy, and taking part in an annual meeting to build consensus on how to move the cooperative forward.

- Members commit an equity share in Co-op Power of $\$ 975$; annual membership dues are $\$ 25$.

Once a sound financial basis has been established for the cooperative, member equity shares are refundable if a member leaves the cooperative.

In addition:

- Co-opPlus and Pioneer Valley Biodiesel Cooperative members have been invited to join Co-op Power at a reduced equity share.

Until July 30, 2005, people who were members of Co-opPlus or the Pioneer Valley Biodiesel Cooperative as of March 28, 2005, can pay $\$ 750$ in equity and have the first year's $\$ 25$ annual fee waived because of the effort these organizations have put forward to establish Co-op Power.

- Anyone under 18 who would like to become a member of Co-op Power must have a parent or guardian sign the member application form.

- Members can spread their equity share payment over 24 months by authorizing automatic withdrawals from their bank accounts. Members on these monthly payment plans begin enjoying member benefits when they have paid one-third of the equity and as long as they are current with payments.

\subsection{Membership Benefits}

Members will have access to:

- Biodiesel and other sustainable energy products and services at significant discounts

- Co-op Power's online energy resources

- Reliable information about sustainable energy

- A share of Co-op Power's distributed profits

- Member-only offerings

- A vote in membership meeting decisions

- Education and community-building events

- Opportunities for volunteer work on committees and projects to build sustainable energy resources in the region.

Membership shares are not like investments in a for-profit corporation. They do not increase in value over time. They do not provide an equity return or dividends. 
Membership shares entitle member-owners access to Co-op Power's products, services, and programs. When people join a housing cooperative, they purchase a member equity share and receive a place to live. When people join a food cooperative, they purchase a member equity share and receive food. In the same manner, when people join Co-op Power, they purchase a member equity share and receive energy products and services.

In the '30s and '40s, people were unable to get electricity if they lived in rural areas. Under Roosevelt's guidance, the U.S. government funded the development of rural electric cooperatives, which brought electricity to $75 \%$ of the landmass of the United States. Those rural electric cooperatives invested in generation and transmission cooperatives to bring electricity to their members. In the '70s, people could not buy organic or natural foods in regular grocery stores, so they came together to build natural food cooperatives to secure access to natural foods. Those food stores also invested in the creation of natural food warehouses to procure food to sell to their members.

Today, people don't have access to the sustainable energy resources they need. The first job of Co-op Power is to invest in the development of renewable energy products and services for its members. Co-op Power is investing in the biodiesel production facility company to secure access to biodiesel. In addition, it will support bulk purchasing of solar energy systems to make them affordable, and it will support bulk purchasing or leasing of diesel vehicles to make them more accessible and affordable. Co-op Power is also researching ways to support community wind projects in the Northeast.

\subsection{Community Benefits}

- Co-op Power will bring the region better options for energy products and services.

- Co-op Power's sustainable energy programs will decrease emissions that cause global warming and air pollution.

- Co-op Power will increase community awareness of the effects of its energy use, energy security, and energy options.

- Co-op Power will secure public policies that build sustainable energy resources.

- Co-op Power will provide quality jobs and anchor capital in the region.

\subsection{Member Risks}

Although many risks are associated with new business development, and there is the possibility that the biodiesel production facility and Co-op Power may not succeed, the members of Co-op Power are at financial risk for only the amount of their equity investment. The board of Co-op Power believes this cooperative has a high likelihood of success. 


\section{$7 \quad$ Legal Structure}

Co-op Power is a cooperative business that is owned and controlled by its consumermembers. It is a corporation that is organized according to Chapter 157 of the Massachusetts General Laws. It is authorized to engage in the purchase, sale, and resale of energy products and energy-related goods and services to members and non-members.

Co-op Power has formed a limited liability corporation for the biodiesel production facility to secure access to biodiesel fuel for its members. Co-op Power plans to engage in bulk purchasing arrangements, joint ventures, and other business start-up activities to secure other products and services for its members.

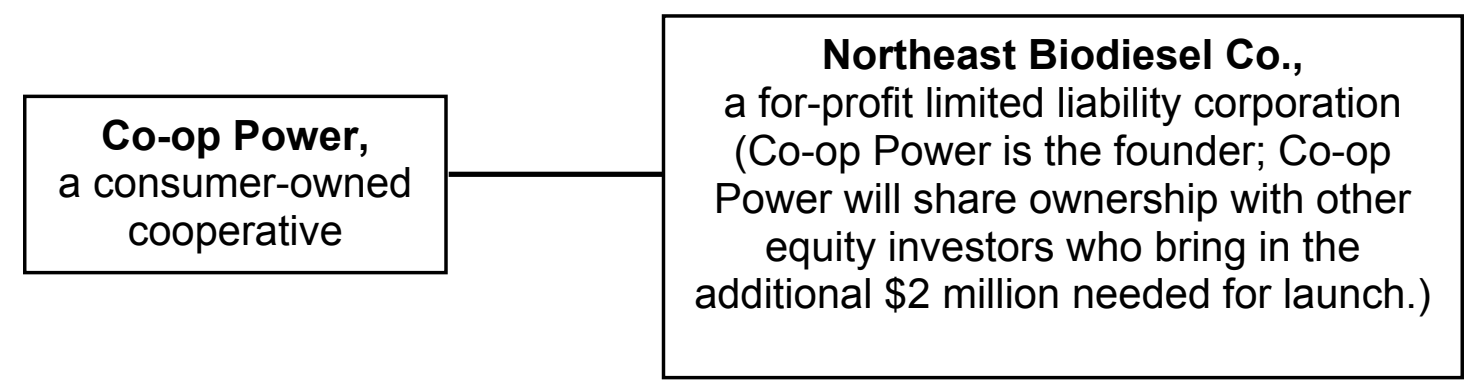

Figure 2. Relationship between Co-op Power and Northeast Biodiesel Co.

Two classes of stock are authorized in the Co-op Power articles of organization filed on Dec. 30, 2004.

Shares of Class A common stock are designated as "membership shares," and holders of Class A common stock are designated as "members." Each member is entitled to one vote on any matter, regardless of the number of shares held. Ownership of Class A common stock is nontransferable, except by the corporation, and the books and records of the corporation constitute the sole proof of ownership. All other powers and rights of Class A common stock shareholders are established by the bylaws and by the board of directors of the corporation.

The board has not authorized the sale of Class B preferred stock at this time. Requirements for the issuance and ownership of Class B preferred stock shall be established by the bylaws and the board of directors of the corporation. If issued in the future, Class B stockholders will not be entitled to vote on any matter before the members. Ownership of Class B preferred stock will be non-transferable, except by the corporation, and the books and records of the corporation will constitute the sole proof of ownership. All other powers, preferences, and rights of Class B preferred stock shareholders will be established by the bylaws and by the board of directors of the corporation.

The cooperative is operated on a service-at-cost basis for the mutual benefit of its members. The cooperative will accumulate only such capital, reserves, and other financial assets as are determined by the board to be necessary and prudent to the ongoing operation of the cooperative's business. 
Within a reasonable time after the end of each fiscal year, the board will determine the net earnings of the cooperative for that fiscal year. The net earnings of the cooperative for that year from all the business of the cooperative, other than business done with or for members or patrons, may be retained by the cooperative as unallocated reserves or surplus. In setting aside funds for reasonable reserves for necessary purposes of the cooperative, the board must first set aside such net earnings.

If there are no net earnings on such business, or if such net earnings are insufficient to provide for reasonable reserves for necessary purposes of the cooperative, as determined by the board, then reasonable reserves may be set aside by the board from the net earnings on business done with or for members or patrons.

The board will adopt an annual budget for the operation of the business and will monitor and review spending performance on this budget on at least a quarterly basis. The board will also adopt a capital plan, which will be reviewed at least annually thereafter, to establish and provide for the capital needs of the cooperative. The capital plan will provide for establishing and maintaining capital in an amount sufficient to maintain the cooperative's facilities and real property owned by the cooperative and to secure access to products and services for members. Each member will contribute capital as required by the capital plan. The cooperative will record all capital contributions made by each member to that member's individual capital account. If capital is accumulated in excess of the amount provided for in the capital plan, such excess shall be returned to members on an equitable basis.

If available, patronage refunds (patronage dividends) will be declared and paid from net earnings (net margin) at the end of each fiscal year, as required in the bylaws. Each year, the cooperative will be obligated to account for and pay on a patronage basis to all members all of the cooperative's net earnings (net margin) over and above the cost of providing services to members, after paying all costs and making reasonable additions to capital and reserves and redeeming capital credits.

All members will be treated equitably, and patronage refunds will be paid in proportion to and based on the volume or value of products and services purchased by each member from the cooperative. Patronage refunds to members will be paid in cash or the equivalent or by an appropriate credit to a member's capital account or in both forms of distribution, as may be determined by the board.

\subsection{Democratic Governance}

Members own and control the cooperative. They elect the board of directors. Membership policies guide the board's actions. The board of directors hires a manager, who oversees the cooperative between board meetings. Board policies guide the manager's actions. 
At an annual meeting, the members of the cooperative will elect directors, receive reports on the operations and fiscal affairs of the cooperative, and transact other business. Members can participate in the meeting in person, by proxy, or by alternate. Fifty percent of the current members must participate in a membership meeting to satisfy quorum requirements. The 2005 annual meeting was held April 16, 2005, by the founding members. The next annual meeting will be held in the spring of 2006. To encourage participation in the 2006 Co-op Power annual meeting, the membership fee will be waived for members who attend in person.

The cooperative has a board of directors of not less than five and not more than 11 directors, who are elected by the members. Each director elected must be a member in good standing of the cooperative.

Co-op Power board members are:

- Sally Wright, chair

- Lynn Di Tullio, vice chair

- Erik Hoffner, treasurer

- David Biddle, clerk

- Tim Rice.

\subsection{Regional Structure}

Developing sustainable energy resources requires a regional approach because a large market with sufficient capital to support expensive infrastructure development is required. As Co-op Power expands to other states, a representative structure will be developed to ensure Co-op Power is responsive to the needs of the members in each state. Board representation by each regional group will be ensured to fairly direct Co-op Power's activities and investments. Membership meetings will be held in each state. As groups join in this effort, the board will engage in dialogue to determine the best strategy for developing this regional structure.

Co-opPlus, serving Western Massachusetts, is the first regional group to affiliate with Co-op Power. 


\section{Co-op Power Products and Services}

Co-op Power will establish bulk purchasing programs and engage in business development activities to secure renewable energy and energy efficiency products and services for its members. It will provide infrastructure to support member bulk purchasing and negotiate volume deals on attractive products. This will be done in the form of marketing agreements, retail bulk purchasing agreements, or direct distributorship to members.

Return on investments in sustainable energy projects by Co-op Power, such as the biodiesel production facility, should be thought of in terms of product (and not as a cash dividend paid out to Co-op Power). Given Co-op Power's cooperative legal status, its main revenues are required to come from product sales to members. For example, the biodiesel production facility will return biodiesel, and a wind project will return value in the form of RECs that Coop Power can then resell to members (with a possible discount or patronage refund benefit) or the public at full price.

The product offerings of Co-op Power will follow a staged rollout.

\section{Phase 1: Start-Up (2005)}

Co-op Power is developing a handful of products to offer members. These include:

- Solar hot water and solar electric systems

- Green power

- Biodiesel for home heating (and maybe transportation)

- 5- and 55-gallon containers with B100 for degreasing or self-blending

- Selected green products with a more significant discount, such as biofuel heaters and boilers, attic fans, and Kill-a-Watt meters, which measure the electricity appliances use

- Green building materials, efficient light bulbs, and efficient doors and windows

- Message products such as T-shirts, bumper stickers, coffee mugs, and caps.

Bulk purchasing agreements will secure an economic benefit for members when they purchase from one of Co-op Power's partners. Those partners will pay a marketing fee back to Co-op Power to cover the operating costs of this service.

Bulk purchasing agreements are relatively easy to establish. They will give members a range of products and services to choose from because not all members are in a position to purchase biodiesel or wind certificates. Typical discounts will range 1\%-5\%. Co-op Power will launch with bulk purchasing agreements for biodiesel, solar energy systems, green power, and waste oil furnaces and will add other products as quickly as possible. 


\section{Phase 2: Ramp-Up (2006)}

To increase economic potential, Co-op Power will further develop bulk purchasing programs and take on the distribution of specific products. Member demand will guide Co-op Power in the development of new products and services. The product portfolio will grow; there are more types of products and more choices for each product type. For example, more biodiesel blends will be available from more places. Membership discounts and profit shares will gradually increase.

- The solar program will move from marketing agreements to actual bulk purchases and design. By coordinating purchases, Co-op Power can further reduce the price of solar power.

- More gas stations in the region will carry biodiesel.

- More biofuel products will be available.

- Wind farm RECs will help members become net-zero fossil fuel users.

The first investment in a local wind farm project will happen quickly. The dividend payment will come back to Co-op Power as RECs. Co-op Power will resell these certificates to members with a discount or patronage refund.

\section{Phase 3: Maturity (2007 and Beyond)}

The product portfolio will be significant.

- More biodiesel options are available.

- The biofuel product range is expanded.

- RECs are available from multiple local projects that members support.

- Many more green products are available through an easy-to-access online catalog.

- Additional discounts are available on services that can be purchased through Co-op Power.

- Financing of efficiency work and solar projects may be available.

- A clean vehicle bulk purchasing or leasing program exists.

Investments in the biodiesel production facility and local wind farms from earlier years are now returning significant dividends. Co-op Power receives dividends in the form of renewable energy products (i.e., biodiesel and RECs). These products are provided to Co-op Power members at significant savings. They will also generate revenue that will provide direct financial support to local sustainability-focused groups around the Northeast and to new sustainable energy projects. Membership discounts and patronage refunds combined can, in some cases, reach $20 \%-40 \%$. 


\subsection{Biodiesel Bulk Purchasing Program}

The biodiesel product will initially be the most important area of economic activity for Co-op Power. All members of Co-op Power will have access to biodiesel at a discount. Furthermore, these purchases will qualify members for a patronage refund when Co-op Power turns a profit and members decide to distribute it. A household bulk purchasing agreement will become standard for members. There will be a maximum quantity that caps how much each member will be able to buy under this standard agreement. However, there will be add-on bulk purchasing agreements for larger quantities. Over time, after up-front discounts and patronage refunds, Co-op Power expects the end price of biodiesel to be quite favorable.

Co-op Power will secure biodiesel for its members through heating oil and diesel fuel distribution partners. Tim Rice of Rice Oil in Greenfield and Steve Chase of Alliance Energy in Holyoke have agreed to provide biodiesel to Co-op Power's members. Pre-purchase agreements for heating oil with a blend of $3 \%$ biodiesel are under discussion for the fall of 2005. Other distribution partners will be secured as Co-op Power's membership grows.

Members will sign annual purchase agreements with, and make payments to, Co-op Power. Co-op Power will contract with the biodiesel production facility for wholesale biodiesel and with the distribution companies for diesel fuel, biodiesel handling, mixing, and distribution.

An economic advantage for Co-op Power members will be guaranteed through two mechanisms:

1. Economies of scale are ensured through bulk purchasing and pre-payment.

2. Co-op Power will receive a significant supply of biodiesel each year as its investment dividend. This biodiesel will be included in supply volumes distributed to members.

Co-op Power will expand the number of home heating oil distributors that offer biodiesel as membership grows. Today, it is defining a pilot program for this year's heating season. The more members who join Co-op Power and sign up for a biodiesel product, the bigger the member savings will be. Co-op Power asks new members how much biodiesel they would like to purchase. Then, based on member location and quantity desired, Co-op Power makes agreements with distributors.

The market for biodiesel-blended home heating oil is the first priority for Co-op Power. The market is predictable, and fueling locations can be established. One distributor agreement can cover a large geographic region. Although the market for retail biodiesel for transportation is less transparent and predictable, Co-op Power will present product offerings for potential customers. 


\subsection{Biofuel Product Program}

As a natural extension of Co-op Power's biodiesel program, the Co-op will resell a range of products catering to the "Grease Economy" (i.e., products that support the expansion of use of both biodiesel and recycled vegetable oil). Discussions are ongoing regarding a product range of "waste oil" heaters and boilers and even an air conditioning unit that uses biodiesel or recycled oils. Co-op Power is in an early stage of negotiating specific terms with a selected manufacturer.

The product line will first add a 5-gallon B100 product (in collaboration with Tom Leue of Homestead Inc.) and then a 55-gallon B100 drum product and various implements to support the use of biodiesel and recycled vegetable oils (e.g., pumps, hoses, and measuring devices).

Over time, Co-op Power will work with members to test and "certify" new products and services and then bring them to a mass market.

\subsection{Renewable Energy Certificate Program}

An REC is the "green" part of green power; it's the 100\% renewable, clean attribute of power that comes from wind farms, solar installations, and other clean power generation technologies. One REC is equal to the green attribute of $1 \mathrm{kWh}$ of power. An excellent REC overview and price information is available on the Web site of the Massachusetts Technology Collaborative (http://www.cleanenergychoice.org/big_picture.htm).

The objective of the REC program is to allow members, and the public, to support projects in which they have an interest and receive a benefit in the form of RECs. Co-op Power pools this interest into the volume acquisition of RECs (via investment or purchase) from these projects. Co-op Power will resell RECs to members (with a possible discount or patronage refund benefit) and to the general public at full price.

Co-op Power will weigh the benefits of supporting wind developers with equity investments or long-term REC purchase agreements. The business plan assumes that Co-op Power will take a direct ownership stake and have dividend returned in the form of RECs.

\subsection{Green Product Resale}

Co-op Power will build a significant online catalog of green products and services for resale to the public (or to members with a discount or patronage refund). Members will determine the products selected for inclusion. The first products will be simple items such as bumper stickers and T-shirts, but the catalog will quickly expand to include green building materials, solar flashlights, and similar items (as determined by member demand).

\subsection{Solar Bulk Purchasing}

Co-op Power's solar program is based on member savings secured through marketing agreements with local dealers. The savings on a solar electric system is well above one-third of the cost of a Co-op Power equity share. Given that such systems are expensive, Co-op Power will reduce the overall system cost through volume transactions and design efficiencies. 


\subsection{Market Research Services}

Co-op Power will develop a market research service for energy product manufacturers and installers. This service will allow members to support the development of sustainable energy products and services. They will be able to provide feedback on marketing plans, product ideas, business plans, pricing, and product design. Co-op Power will provide a specialized form of market research services to businesses interested in the "green" consumers of the Northeast.

\subsection{Annual Meeting and Expo}

Co-op Power will hold an annual meeting and sustainable energy expo to educate members and the public about sustainable energy products and services.

\subsection{Innovative Volunteer Programs}

Co-op Power will organize a volunteer team to work with Nueva Esperanza in Holyoke to develop programs that promote energy conservation and efficiency in 40 apartment buildings. This will be followed by similar work in other low-income neighborhoods. Co-op Power will support fundraising efforts that enrich renewable energy resources in these communities. The purpose is to reduce energy costs and protect the environment. In later years, after the economic foundation of Co-op Power has been built, there will be money in the budget to fund such activities directly.

\subsection{Sustainable Energy Education and Public Policy Advocacy}

Co-op Power will provide energy education and public policy advocacy resources for its members online, through events, and through print materials. These efforts will promote energy conservation and efficiency and renewable energy.

\subsection{Regional Meetings}

Regional member meetings will allow members to meet in person, share ideas, and build consensus on direction for the co-op. Meetings will also help organize members' volunteer efforts (e.g., educational activities or the development of energy resources in low-income communities) to support the co-op mission. Staff will develop a calendar of events for education, training, and informal discussion.

\subsection{Innovative Information Technology}

The heart of Co-op Power is its bond with its members. Co-op Power will use an innovative information technology structure that gives members $24 / 7$ access to:

- Their accounts

- Co-op Power's products and services

- Information about the cooperative, sustainable energy, public policy initiatives, and one another.

The product purchasing and member account infrastructure is being built on PurchasingInfo.com. PurchasingInfo's flagship purchasing automation software provides a secure platform for online purchasing. Co-op Power can post deals negotiated with vendors and easily track marketing fees and membership discounts. Members will be able to easily monitor their purchases. 
A Web site will provide information to the public about sustainable energy resources and a wiki resource section will allow members to access and edit information about related topics.

An online forum is being built on Cooperative Life's open source software platform, which is written in Plone. The online community will provide the primary vehicle for member communication and relationship building. It will be used to build consensus on the cooperative's vision and mission, the products and services to be offered, and other membership benefits. Members will be able to access and contribute to information about sustainable energy and organize support for new sustainable energy projects. It will be a place to ask questions, find answers, see announcements, share ideas, build co-op consensus, and find help. A member directory will link members with one another.

Figure 3 is a conceptual graphic outline of what the Co-op Power home page could look like. 
S Microsoft Internet Explorer provided by Verizon Online

File Edit view Favorites Iools $\underline{\text { Help }}$

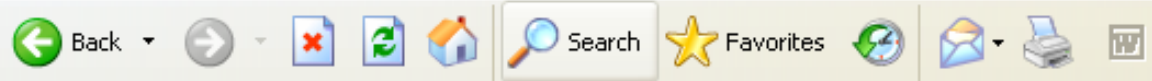

Address hittp:/iwww,co-oppower.coopl

\section{Co-op Power}

"Community Power with Purpose"

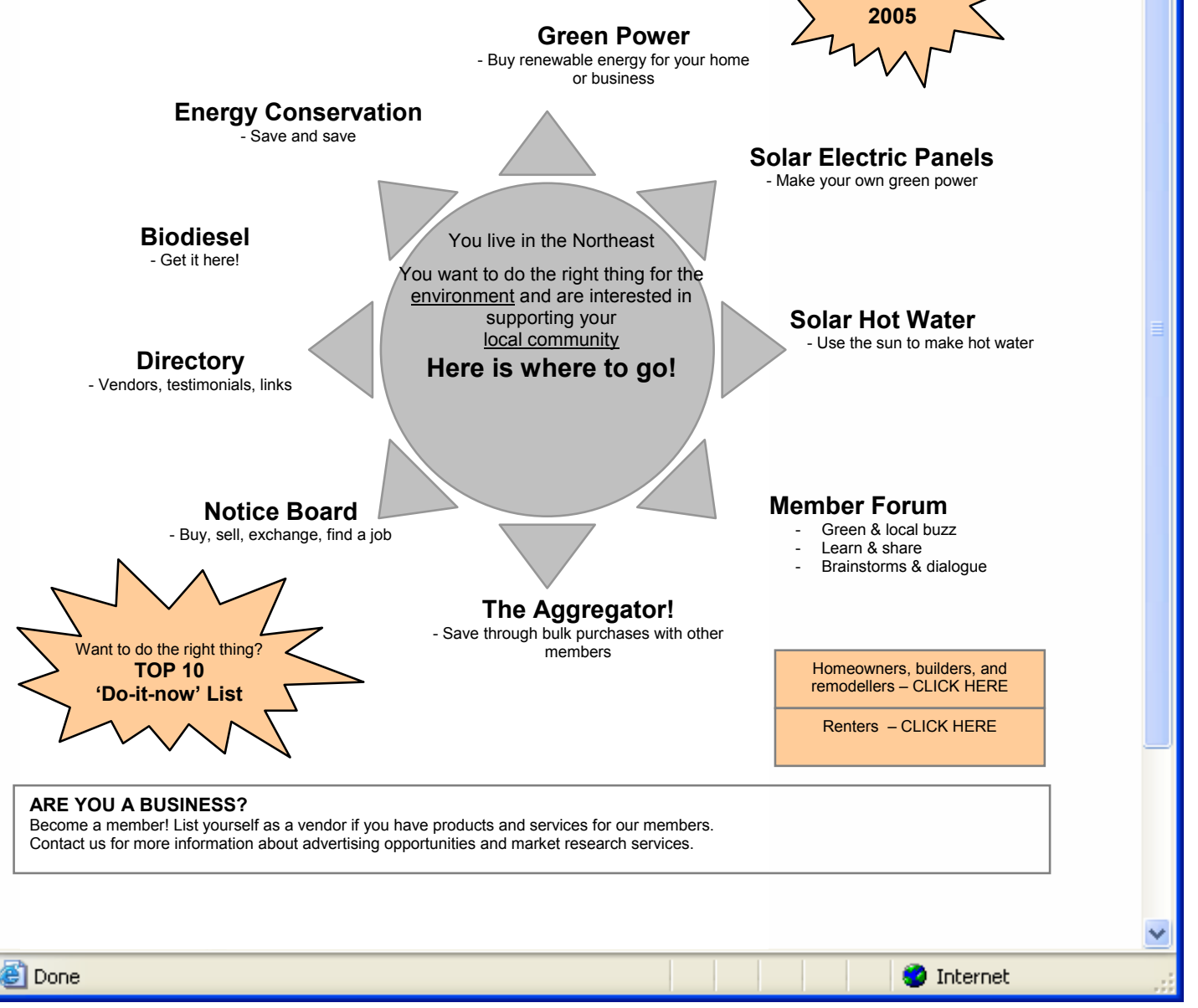

Figure 3. Conceptual graphic outline of Co-op Power home page 
The topics to be represented on the Co-op Power Web site include:

- Green power and green tags

- Information about one or more pre-negotiated, economically favorable co-op deals

○ Educational information and links to relevant Web resources

○ Testimonials from members who have signed on for one of the packages

- Solar electric panels

- Information about one or more pre-negotiated, economically favorable co-op arrangements

○ An "incentive alert" that announces opportunities for financial support

- Educational information about why and when solar electric panels make sense and links to relevant Web resources

- Testimonials and pictures from members with photovoltaic installations

- A Web form that collects information for co-op support

- Solar hot water

- Information about one or more pre-negotiated, economically favorable co-op arrangements

○ An "incentive alert" that announces opportunities for financial support

$\circ$ Educational information about why and when solar hot water makes sense and links to relevant Web resources

- Testimonials and pictures from members with solar hot water installations

- A Web form that collects information for co-op support

- Biodiesel for vehicles and home heating

- Information about one or more pre-negotiated, economically favorable co-op arrangements

○ An "incentive alert" that announces opportunities for financial support

○ Educational information and links to relevant sites

- Specific information about retail availability and the use of biodiesel 
- Energy conservation

- Information about one or more pre-negotiated, economically favorable co-op deals

- An "incentive alert" that announces opportunities for financial support

- Educational information and links to relevant resources on the Web

- Community wind

- Co-op Power will negotiate investment terms with community wind projects in the region to secure RECs for members and provide financing for development. 


\section{$9 \quad$ Key Goals}

\subsection{Goals for 2005}

The goals for 2005 are to:

- Establish a model for cooperative ownership by consumers of significant sustainable energy assets in the Northeast

- Enroll 425 members to establish sufficient capital to support Co-op Power's launch and secure the biodiesel production facility's start

- Construct a building using the \$250,000 U.S. Department of Agriculture Renewable Energy grant and lease it to the biodiesel production facility

- Establish biodiesel distribution relationships with heating oil dealers and diesel distributors in the region

- Invest in a community wind project and sell RECs to members

- Establish Co-op Power with two employees, an office, and a business infrastructure

- Negotiate discounts with suppliers on bioheat.com, renewableenergyaccess.com, and other sustainable energy online vendors.

- Launch the larger Co-op Power Web site, including the online forum and education resources

- Establish regular community meetings and other infrastructure for democratic participation in Co-op Power and to help members.

\subsection{Goals for 2006}

The goals for 2006 are to:

- Deliver the first locally produced biodiesel to members

- Expand membership benefits

- Expand membership coverage across the Northeast by enrolling an additional 1,000 members

- Establish a platform for a democratic process online to support co-op decisionmaking.

\subsection{Goals for 2007 and Beyond}

Future goals are to:

- Add 10\% more members each year

- Foster a vibrant cooperative membership that decides the direction of the next sustainable-energy products and services to be built

- Initiate work on the second significant sustainable energy project. 


\section{How Co-op Power Will Benefit the Biodiesel Production Facility}

Co-op Power formed the biodiesel production facility. The relationship between the two will be enhanced by the flow of benefits from Co-op Power to the biodiesel production facility as described below.

- Co-op Power has invested $\$ 375,000$ in biodiesel production facility development. The board has pledged another $\$ 125,000$ in equity in the next 6 months. In 16 months, Coop Power will add another $\$ 800,000$ in equity to support the biodiesel production facility expansion to 10 million gallons/year in production.

- Co-op Power members will open the consumer market for biodiesel by working with their heating oil dealers and diesel distributors to encourage them to offer a biodiesel blend. Members will sign pre-purchase agreements for their biodiesel each year. Coop Power members will turn NIMBY (not in my backyard) to WIMBY (where in my backyard) by encouraging friends, neighbors, colleagues, the press, and public officials to promote biodiesel.

- Co-op Power is preparing to purchase the land and construct the building for the biodiesel production facility and then lease it to the biodiesel production facility to support overall financing for this important business start-up project. 


\section{Outreach Strategy for Enrolling New Members}

\subsection{Core Message}

The goal is to make the availability of sustainable energy a reality for the community-an objective that is shared with people across Europe and Canada, who have made impressive progress in this area.

Renewable energy resources are complex and expensive. It takes $\$ 2$ million-\$3 million to build a community wind project and several million dollars to build a biodiesel production facility. If these resources are to be community-owned, the community needs to invest in them now.

Securities laws make community ownership difficult in the US. It is not easy for everyday folks to pool their money and build big things. Although they may not be able to pool money for investments, the cooperative structure allows them to pool money to secure access to products and services they want to use.

Co-op Power is a way for community ownership to make a difference. Co-op Power will allow members to pool money to secure access to sustainable energy products and services.

- Co-op Power will build the biodiesel production facility to produce a home-heating and transportation fuel that is biodegradable, clean-burning, and made from recycled vegetable oil. Blended with petroleum-based diesel, it can be used in any oil burner or diesel engine without modification.

- Co-op Power will invest in local wind projects to secure access to RECs.

- Co-op Power will secure access to a host of other sustainable energy resources, including solar attic fans and other solar energy systems, waste vegetable oil burners, and efficient windows and doors.

- After 3 years, it is anticipated that Co-op Power will give $\$ 0.15-\$ 0.20$ back on each dollar spent on its energy products and services.

- After 5 years, Co-op Power is expected to generate more than $\$ 250,000$ a year in development funds for the building of new sustainable energy resources in area communities.

Joining Co-op Power means:

- Investing \$975 for a membership share and \$25 for an annual membership fee

- Potentially earning back $\$ 1,000$ of benefits within 6-7 years (if the member purchases some of Co-op Power's energy products and services)

- Earning $\$ 1,000$ dollars back sooner if the member buys an item such as a solar hot water system or a furnace that burns waste vegetable oil. 
Member equity will be held in trust until there are enough members to launch. If a membership is cancelled, the equity portion will be refundable once the business has become established.

The goal is for 425 people across New England and New York to join Co-op Power by October 2005 and for 1,000 to join by the summer of 2006 .

\subsection{Audiences}

The four groups most likely to join Co-op Power, in priority order, are:

- The Carbon Reduction Group People concerned about global warming, committed to energy conservation/efficiency and clean energy sources, and committed to sustainable development

- The Energy Security Group People concerned about U.S. dependence on foreign oil, interested in local energy resources, and concerned about how long oil resources will be affordable and available

- The Air Quality Group People concerned about respiratory health, committed to reducing air pollution, and interested in clean energy sources

- The Local Economy Group

People interested in local economic development, local jobs and consumer cost savings, and - for some - sustainable development.

\subsection{Outreach Materials}

Co-op Power has developed the following handouts to support its outreach efforts:

- "Steps You Can Take to Reduce Air Pollution and Greenhouse Gases" Gives specific recommendations for individuals

- "There Is a Different Way ..."

Gives an overview of the vision of Co-op Power and how it wants to make a difference in the world

- “Join Co-op Power" Gives a sense of the benefits of joining Co-op Power

- "Member Sign Up"

Provides forms (both the standard version and versions for special discount groups).

In addition, Co-op Power has developed "Join Co-op Power," a PowerPoint presentation. 


\subsection{Resource Packets}

Co-op Power has developed resource packets for each significant area in which it is working, including:

- Biodiesel

- Wind

- Solar

- Community asset ownership. 


\section{Outreach Activities for Western Massachusetts}

A rigorous outreach campaign has been designed to sign on 425 members by the end of October 2005 and 1,000 members by the end of 2006 .

\subsection{Co-op Power Tabling}

A table with information about Co-op Power and sustainable energy demonstrations will be staffed in the following locations:

- Greenfield Farmers Market

Held at the Town Common, located on Main St. in Greenfield, Saturdays 8 a.m. $-12: 30$ p.m.

- Orange Farmers Market

Held at Butterfield Park, located on East River St. in Orange, Thursdays 3-6 p.m.

- Ashfield Farmers Market

Held Saturdays 8:30 a.m.-12:30 p.m. on Route 116 in the center of Ashfield

- Greenfields Market

Held Saturdays

- McCuskers Market

Held in Shelburne Falls

- Third Friday at the Falls

Held throughout Shelburne Falls the third Friday of each month 5-8 p.m. and featuring art openings, live music, food, special events and artisan demonstrations

- Thursday Coop Concerts

Held in the Greenfield Energy Park, located at the end of Miles St. in Greenfield, Thursdays 6-8 p.m.

- Co-op Power Northampton office.

\subsection{Co-op Power Outreach Events}

A table with information about Co-op Power and sustainable energy demonstrations will be staffed on the following dates and in the following locations:

- July 8: Classic Day at Northeast Sustainable Energy Association in Greenfield

- July 15-16: Solar Fest in Vermont

- July 22-24: Annual Yankee Doodle Days, Charlemont's Hometown Fair

- July 29: Last Fridays, Critical Mass Bike Rides, 5:30 p.m. (ride at 6 p.m.), Pulaski Park, Main St., Northampton

- July 30: Salmon Falls Land Association promotes the launch of Co-op Power and other cooperative efforts in Western Massachusetts, 4 p.m., 127 Main St., Shelburne Falls, Massachusetts 
- July 30: Community Against Hate Open Mic, 9:30 p.m., Latin Flava Café, 1677 Main St., Springfield

- July 31-August 6: Center for Popular Economics Annual Summer Institute, Amherst

- July 31: Last Sundays, Northampton Community Resource Center potluck, 6 p.m., Northampton Community Resource Center located in the basement of First Churches, Center and Main streets, Northampton

- Aug. 4-7: Grassroots Radio Conference and Valley Free Radio Barn Raising, Florence and Northampton

- Aug. 6: Amy Goodman performance, 8 p.m., John M. Greene Hall, Smith College, Route 9, Northampton

- Aug. 19-21: Annual Heath Fair, fairgrounds on West Hosmer Road, Heath

- Aug. 19-21: 46th Annual Montague Old Home Days, the common in Montague Center, Friday 6-10 p.m. and Saturday 8 a.m.-10 p.m.

- Aug. 27: Annual Shelburne Grange Fair, Fellowship Hall, off Route 2, Shelburne Center, 9 a.m.-4 p.m.

- Sept. 8-11: 157th Annual Franklin County Fair, Franklin County Fairgrounds, Wisdom Way, Greenfield

- Sept. 16-Oct. 2: The Big E - Eastern States Exposition, exposition grounds, West Springfield, daily 8 a.m. -10 p.m.

- Sept. 17-18: 7th Annual North Quabbin Garlic and Arts Festival - The Festival That Stinks, Forster's Farm, 60 Chestnut Hill Road, Orange, 10 a.m. -5 p.m.

- Sept. 25: 3rd Annual 1794 Meetinghouse Musicfest, 1794 Meetinghouse on the common, New Salem, noon-7:30 p.m.

- End of September: Biodiesel bus tour

- Oct. 2: 44th Annual Conway Festival of the Hills

- Oct 8: 1st Annual Amherst Energy Fair, Amherst South Common, 10 a.m.-3 p.m.

- Oct. 8-10: Annual Pumpkin Festival, Route 2 and Tower Road, Charlemont, 10 a.m.4 p.m.

- Nov. 5: The Cornucopia Auction, The Academy, 359 Route 2, Charlemont, 7-10 p.m.

- Nov. 5-6: 11th Annual Apple and Cider Day, various locations in Franklin County, 10 a.m. -4 p.m. 


\subsection{Phoning}

Phone lists of Co-opPlus members, community leaders in Western Massachusetts, and regional leaders will be used to organize phone-a-thons. The 1,400 household members of CoopPlus will be called at the end of July to encourage membership sign-up before the discounted equity offer expires. Community leaders in Western Massachusetts will be called in early August. Regional leaders will be called mid-August.

Phone-a-thons will be scheduled at the Greenfield office and will include a phone list with space to indicate the outcome of the call and follow-up required, a script, and answers to frequently asked questions. Volunteers will have a brief training before calls begin and will participate in a debriefing session following their calls. The coordinator will monitor call lists, follow-up required with individual members, and outcomes.

\subsection{House Parties}

Members will sign up to host parties at their houses with friends and neighbors.

\subsection{Presentations at Churches, Synagogues, and Other Religious Organizations}

Presentations will be given and announcements will be posted in the newsletters of churches, synagogues, and other religious organizations, including:

- Northampton Synagogue

- Greenfield Synagogue

- All Souls Unitarian in Greenfield

- Springfield Unitarian

- Second Congregational in Greenfield

- Mount Toby Quaker Meeting

- Interfaith Council in Greenfield

- Charlemont Federated.

\subsection{Presentations for Other Organizations}

Information will also be shared with other organizations, including:

- The Greenfield Landlords Association

- The Traprock Peace Center

- The American Friends Service Association

- The Shelburne Falls Area Business Association

- The Rocky Hill Cohousing Community

- Chambers of commerce

- Rotaries

- The Post Carbon Council

- The Northeast Sustainable Energy Association. 


\section{Media Plan}

Plans for media outreach to support the outreach efforts are described below.

\subsection{Press Releases}

The schedule outlined below will be followed.

Table 2. Press Release Schedule

\begin{tabular}{|c|c|}
\hline News & $\begin{array}{l}\text { Estimated } \\
\text { Date }\end{array}$ \\
\hline Launch of membership drive & July 20 \\
\hline $\begin{array}{l}\text { Signing of the purchase and sale agreement for the land for the biodiesel production } \\
\text { facility }\end{array}$ & July 28 \\
\hline First 50 members of Co-op Power & Aug. 2 \\
\hline $\begin{array}{l}\text { Contract signed between Alliance Energy and Rice to provide biodiesel for home } \\
\text { heating }\end{array}$ & Early August \\
\hline $\begin{array}{l}\text { Co-op Power's online community launched, member testimonials of the value it } \\
\text { brings }\end{array}$ & Mid-August \\
\hline$\$ 2$ million in equity secured for the biodiesel production facility & Mid-August \\
\hline $\begin{array}{l}\text { Co-op Power breaks } 100 \text { members, compelling story of why the 100th member } \\
\text { joined }\end{array}$ & Mid-August \\
\hline$\$ 1.8$ in debt secured for the biodiesel production facility & End of August \\
\hline Co-opPlus announces $\$ 10,000$ returned to members for solar installations & $\begin{array}{l}\text { Early } \\
\text { September }\end{array}$ \\
\hline $\begin{array}{l}\text { Co-op Power enrolls more than } 200 \text { members, has "\#" gallons of biodiesel under } \\
\text { contract }\end{array}$ & Mid-September \\
\hline Co-op Power enrolls more than 300 members, has discount on waste heat burners & $\begin{array}{l}\text { End of } \\
\text { September }\end{array}$ \\
\hline $\begin{array}{l}\text { Co-op Power enrolls more than } 400 \text { members, innovative Web site launched to } \\
\text { make member bulk purchasing easy }\end{array}$ & Early October \\
\hline Co-op Power launches, "Community Ownership Makes a Difference" testimonial & Mid-October \\
\hline Groundbreaking for the biodiesel production facility, press conference & End of October \\
\hline The biodiesel production facility begins production & $\begin{array}{l}\text { End of } \\
\text { February }\end{array}$ \\
\hline $\begin{array}{l}\text { Co-op Power enrolls more than } 750 \text { members, has members in all seven Northeast } \\
\text { states }\end{array}$ & End of March \\
\hline $\begin{array}{l}\text { Co-op Power enrolls more than } 1,000 \text { s member, holds barbecue with Willie Nelson } \\
\text { performing }\end{array}$ & Summer 2006 \\
\hline
\end{tabular}


For each release, the following activities will be completed:

- Write press releases

- Send releases out

- Follow up with calls to media outlets

- Build relationships with reporters/writers and cultivate feature stories

- Use local stories to get to the Associated Press, Green Living, Utne Reader, and CoOp America

- Use regional stories to get to the Globe and New York Times.

\subsection{Radio Interviews}

For radio interviews, the following activities will be completed:

- Develop a few people to do radio spots and practice to get the sound bites clear

- Develop a list of shows to target

- Secure radio interviews

- Send background information to show hosts

- Get speakers to the shows

- Tape the shows.

Talk shows will give updates on what Co-op Power is doing and why and talk about the value of community ownership, the value of biodiesel and wind and solar energy, and how innovative online technology can bring people together to learn and save money.

Radio stations/shows that will be targeted include:

- Valley Free Radio

- WRSI

- WAMC - Regional Roundtable with Susan Arbetter and Joe Donahue

- WAMC - Living on Earth (national)

- WFCR

- WHAI

- WAQY.

\subsection{Feature Stories}

Co-op Power will work with editors at the Greenfield Recorder, Springfield Republican, Hampshire Gazette, Progressive Voice, the Associated Press in Springfield, Orion, Green Living Magazine, Channel 40, Co-op America, Globe Magazine, and the New York Times Magazine to develop feature stories. 
Some feature story ideas are:

- Christian Lagier's story (growing up in Denmark, managing Co-op Power, and the history of Danish investment in community power)

- Larry Union's story (growing up in Fleet, Michigan; working for General Motors; managing the Connecticut Energy Cooperative and now the biodiesel production facility, and comparing corporate alternatives)

- Sally Wright's story (supporting community wind from the University of Massachusetts Renewable Energy Laboratory and Co-op Power's unique role in the development process)

- Biodiesel and the importance of community ownership of alternative fuel sources

- Biodiesel use in local school bus fleets

- Kay Cafasso's film about sustainable energy and sustainable agriculture

- Tom Leue's story about the making of biodiesel from waste vegetable oils.

\subsection{Newsletter Announcements}

Co-op Power will work with partner organizations to encourage their people to join by including announcements and information in their newsletters, in mass e-mails to their mailing lists, and in their outreach activities. 


\section{Key Partnerships}

As a regional organization, Co-op Power has developed collaboration partnerships with key local and regional organizations. These include:

- Massachusetts Renewable Energy Trust, The Connecticut Clean Energy Fund, and renewable energy trusts in other Northeast states

- Center for Ecological Technology

- Northeast Sustainable Energy Association

- Pioneer Valley Sustainability Network

- Pioneer Valley Photovoltaic Cooperative

- Nueva Esperanza

- Rural Development Inc.

- Mass Energy

- Permaculture Guild

- Sustainable Step New England

- Rocky Mountain Institute

- Solar Partners

- Photovoltaic electric vehicle users group

- Biodiesel@easymailings.com

- Northeast Organic Farming Association - Massachusetts Chapter

- Farmers Exchange

- Community Involved in Supporting Agriculture

- Citizen Action Network

- Franklin County Landlords Association

- American Friends Service Committee

- Traprock Peace Center

- All Souls Unitarian Church

- Greenfields Market

- River Valley Market.

These organizations may assist with product and service development as well as membership development. These relationships will be expanded over time. 


\section{Regional Chapter and Membership Development}

Over the past 10 years, communities across the Northeast have assessed the opportunities for developing energy cooperatives. These communities include people in membership organizations committed to sustainable energy and represent more than 2 million. They included groups from Rochester, Ithaca, Syracuse, New York City, and Albany, New York; Providence, Rhode Island; Boston and Cape Cod, Massachusetts; Western Massachusetts; and regions of New Hampshire, Maine, Connecticut, and Vermont.

Co-op Power will build on the energy cooperative development network in the region. It will make calls to build relationships and hold a workshop in early September to bring together key stakeholders in other parts of the region to discuss opportunities for partnership. It will share its business plan and legal structure to see if any are interested in joining or replicating parts of what Co-op Power is doing to build a strong network and capitalize on the development of sustainable energy resources in the region. Development plans need to be put in place to support other Co-op Power "chapters" in the region and define decision making and governance participation. The Co-op Power proposal is for Co-op Power "chapters" to receive core operating funds and support for local development efforts once they have 200 members signed up in their region.

The goal of reaching 1,000 members requires a successful regional outreach strategy.

\subsection{Regional Events}

Co-op Power plans to participate in the following regional events:

- Northeast Organic Farming Association Conference, Hampshire College

- Pre-Conference on Biodiesel, Aug. 11-12

- Northeast Organic Farming Association Summer Conference, Aug. 13

- Common Ground Fair

- Blue Hill Fair

- Northeast Sustainable Energy Association events. 


\subsection{Potential Outreach Partners to Contact}

Potential outreach partners include:

- Northeast Sustainable Energy Association

- Food cooperatives

- Energy cooperatives

- Heating oil companies

- Peak oil groups

- Fleets and municipalities that use biodiesel already

- Frontier

- Mass Energy

- Center for Ecological Technology

- Vermont Energy Investment Corp.

- Katadin Center

- Southern New Hampshire University Community Economic Development Program

- Cornell University

- University of Vermont. 


\section{Staffing}

Christian Lagier and Lynn Benander are providing interim management services to Co-op Power during its launch phase.

To execute the programs noted above, Co-op Power will initially require two fulltime positions.

The manager will be responsible for:

- Product development

○ Define new product development goals in consultation with members.

- Develop new products, features, and options.

- Develop new vendor relationships, as needed.

- Negotiate member discounts and Co-op Power marketing fees.

- Product management

- Maintain strong vendor relations.

- Adapt agreements, as needed.

- Track member satisfaction.

- Surface problems and correct them.

- Ensure purchased products reach their destinations.

- Monitor quality assurance.

- Marketing and sales

- Define marketing and sales goals for membership and sales growth.

- Research target market.

- Develop a marketing and sales strategy to reach the target market.

- Implement strategy.

- Monitor progress toward goals.

- Renewable energy project development

○ Define new investment and development goals in consultation with members.

- Develop new projects.

- Monitor progress toward the goals established in the planning process.

- Fundraising for education programs and renewable energy development activities

○ Develop fundraising plan.

- Submit proposals.

- Monitor implementation.

- Provide reports as needed.

- Monitor overall progress toward the goals established in the fundraising plan. 
- Technology development and maintenance

- Define the technology infrastructure required to support member education, networking, resource sharing, purchasing, and decision making for Co-op Power's membership.

- Create a plan to phase in technology resources.

- Implement the plan and monitor progress to achieve goals.

- Financial management

- Board reporting and support for the board's work

- The biodiesel production facility plant management

- Office and human resource management.

A membership coordinator will be responsible for:

- Membership service

- Sign up and orient new members.

- Solicit member input.

- Respond to member inquiries.

- Organize member volunteer activities.

- Support member participation in governance.

○ Organize member events.

- Online community moderation.

- Monitor member participation in online discussions.

- Participate in discussions.

○ Initiate activities when needed.

Bookkeeping and accounting will be outsourced.

Market research services will not be provided until staff or consultants can be hired to define the research goals of the renewable energy company client, create research instruments for use with members online, gather data, analyze data, and create reports for clients.

Co-op Power's volunteer board and outsourced services will provide accounting, technical, and legal help for the two full-time employees.

A full-time purchasing director will be hired in 2008 to negotiate contracts and develop new sustainable energy products and services with economic benefit for members. This person will expand the bulk-purchasing program and the direct marketing and fulfillment aspects of the cooperative. 
In 2010, Co-op Power will hire a lawyer to serve as the community project developer. This full-time person will assist communities in the region in the development of sustainable energy projects. He or she will be an integral part of the "WIMBY" program. The lawyer will have business planning and project finance experience. He or she will also provide legal counsel to Co-op Power. 


\section{Pro Forma Financials}

\subsection{Grant Funding}

Co-op Power has secured (through Co-opPlus) a \$250,000 U.S. Department of Agriculture Renewable Energy grant for the biodiesel production facility's building. Co-op Power will also generate other revenues from government or foundation grants to support public education, member education, and the development of new sustainable energy projects.

\subsection{Pro Forma Income Statement}

Table 3. Pro Forma Income Statement

\begin{tabular}{|c|c|c|c|c|c|c|c|c|}
\hline Revenue & \multicolumn{3}{|c|}{2005 (6 months) } & \multicolumn{2}{|l|}{2006} & \multicolumn{2}{|l|}{2007} & 2008 \\
\hline Value of biodiesel dividend from Northeast Biodiesel & $\$$ & - & $\$$ & 112,500 & $\$$ & 137,500 & $\$$ & 212,500 \\
\hline Revenue from biodiesel bulk purchasing \& resale & $\$$ & - & $\$$ & 96,916 & $\$$ & 108,609 & $\$$ & 147,173 \\
\hline BioFuel product program revenues & $\$$ & 5,752 & $\$$ & 35,527 & $\$$ & 77,821 & $\$$ & 126,881 \\
\hline Green products resale & $\$$ & - & $\$$ & 10,000 & $\$$ & 15,000 & $\$$ & 20,000 \\
\hline Wind farm REC dividend \& resale revenues & $\$$ & - & $\$$ & - & $\$$ & 80,938 & $\$$ & 80,938 \\
\hline Northeast Biodiesel expansion investment & $\$$ & - & $\$$ & - & $\$$ & - & $\$$ & 187,500 \\
\hline Solar bulk purchasing program & $\$$ & - & $\$$ & 1,763 & $\$$ & 18,750 & $\$$ & 18,750 \\
\hline Green power program & $\$$ & - & $\$$ & 800 & $\$$ & 800 & $\$$ & 800 \\
\hline Market Research Services & $\$$ & - & $\$$ & 10,000 & $\$$ & 15,000 & $\$$ & 20,000 \\
\hline Annual Meeting \& Expo & $\$$ & - & $\$$ & 15,000 & $\$$ & 18,750 & $\$$ & 23,438 \\
\hline Notice Board (classifieds) & $\$$ & - & $\$$ & 1,200 & $\$$ & 1,500 & $\$$ & 1,875 \\
\hline Directory & $\$$ & - & $\$$ & 5,400 & $\$$ & 6,750 & $\$$ & 8,438 \\
\hline Advertising/Sponsorship & $\$$ & 15,000 & $\$$ & 18,750 & $\$$ & 23,438 & $\$$ & 29,297 \\
\hline Grant funding & $\$$ & 37,500 & $\$$ & 56,250 & $\$$ & - & $\$$ & - \\
\hline Membership fees & $\$$ & 12,250 & $\$$ & 35,000 & $\$$ & 38,500 & $\$$ & 42,350 \\
\hline Total Revenues & $\$$ & 70,502 & $\$$ & 399,105 & $\$$ & 543,355 & $\$$ & 919,938 \\
\hline Expenses & \multicolumn{3}{|c|}{2005 (6 months) } & \multicolumn{2}{|l|}{2006} & \multicolumn{2}{|l|}{2007} & 2008 \\
\hline Biodiesel CGS, sales \& distribution & $\$$ & - & $\$$ & 72,971 & $\$$ & 88,305 & $\$$ & 108,484 \\
\hline BioFuel product program CGS, sales, marketing & $\$$ & 10,447 & $\$$ & 32,685 & $\$$ & 70,817 & $\$$ & 114,396 \\
\hline Green products - cost of goods sold & $\$$ & - & $\$$ & 8,500 & $\$$ & 12,750 & $\$$ & 17,000 \\
\hline Solar bonus paid to members & $\$$ & - & $\$$ & 705 & $\$$ & 7,500 & $\$$ & 7,500 \\
\hline Pre-launch budget & $\$$ & 129,750 & & & & & & \\
\hline Marketing \& sales expenses & $\$$ & 12,000 & $\$$ & 32,000 & $\$$ & 40,000 & $\$$ & 75,000 \\
\hline Member services & $\$$ & 5,000 & $\$$ & 5,000 & $\$$ & 15,000 & $\$$ & 15,000 \\
\hline Board of directors & $\$$ & 1,000 & $\$$ & 1,000 & $\$$ & 5,000 & $\$$ & 5,000 \\
\hline Outsourced services & $\$$ & 22,020 & $\$$ & 23,520 & $\$$ & 35,040 & $\$$ & 35,040 \\
\hline Salaried staff & $\$$ & - & $\$$ & 158,270 & $\$$ & 163,018 & $\$$ & 247,709 \\
\hline The "WIMBY" Project - Supporting Local Groups & $\$$ & - & $\$$ & 10,000 & $\$$ & 30,000 & $\$$ & 80,000 \\
\hline Rent & $\$$ & - & $\$$ & 4,000 & $\$$ & 4,000 & $\$$ & 4,000 \\
\hline Telephone \& Utilities & $\$$ & 1,500 & $\$$ & 1,500 & $\$$ & 1,500 & $\$$ & 1,500 \\
\hline Supplies \& technology & $\$$ & 1,700 & $\$$ & 3,700 & $\$$ & 1,700 & $\$$ & 1,700 \\
\hline Software Licenses & $\$$ & 1,900 & $\$$ & 2,090 & $\$$ & 2,299 & $\$$ & 2,529 \\
\hline Miscellaneous expenses & $\$$ & 8,000 & $\$$ & 12,000 & $\$$ & 15,000 & $\$$ & 17,000 \\
\hline Total Expenses & $\$$ & 193,317 & $\$$ & 367,940 & $\$$ & 491,929 & $\$$ & 731,857 \\
\hline Gross Profit (loss) before taxes & $\$$ & $(122,815)$ & $\$$ & 31,165 & $\$$ & 51,425 & $\$$ & 188,081 \\
\hline Taxes & $\$$ & - & $\$$ & - & $\$$ & - & $\$$ & - \\
\hline Profit (loss) before patronage refunds & $\$$ & $(122,815)$ & $\$$ & 31,165 & $\$$ & 51,425 & $\$$ & 188,081 \\
\hline Patronage refund & $\$$ & - & $\$$ & - & $\$$ & - & $\$$ & 94,041 \\
\hline Net profit (loss) & $\$$ & $(122,815)$ & $\$$ & 31,165 & $\$$ & 51,425 & $\$$ & 94,041 \\
\hline
\end{tabular}




\subsection{Pro Forma Balance Sheet}

Table 4. Pro Forma Balance Sheet

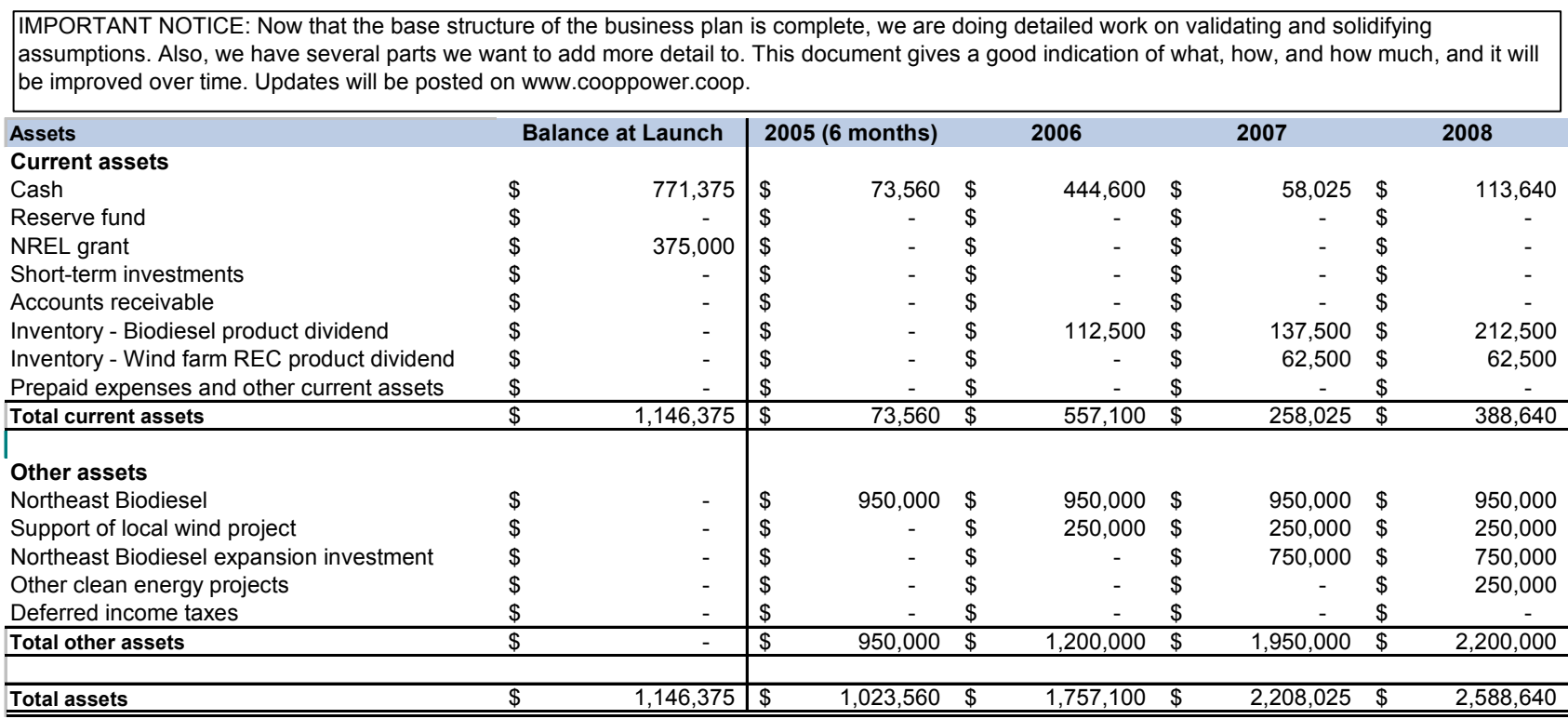

\begin{tabular}{|c|c|c|c|c|c|c|c|c|}
\hline \multirow{3}{*}{$\begin{array}{l}\text { Liabilities \& Equity } \\
\text { Liabilities } \\
\text { Lonq-term debt }\end{array}$} & Balance at Launch & \multicolumn{2}{|l|}{2005 (6 months) } & 2006 & \multicolumn{2}{|r|}{2007} & \multicolumn{2}{|r|}{2008} \\
\hline & & & & & & & & \\
\hline & & $\$$ & $\$$ & - & $\$$ & - & $\$$ & - \\
\hline Income taxes payable & $\$$ & $\$$ & $\$$ & - & $\$$ & - & $\$$ & - \\
\hline Accrued retirement and profit-sharing contributio & $\$$ & $\$$ & $\$$ & - & $\$$ & - & $\$$ & - \\
\hline Long-term debt & $\$$ & $\$$ & $\$$ & - & $\$$ & - & $\$$ & - \\
\hline Deferred income taxes & $\$$ & $\$$ & $\$$ & - & $\$$ & - & $\$$ & - \\
\hline Deferred credits and other liabilities & $\$$ & $\$$ & $\$$ & - & $\$$ & - & $\$$ & - \\
\hline Total liabilities & $\$$ & $\$$ & $\$$ & - & $\$$ & - & $\$$ & - \\
\hline \multicolumn{9}{|l|}{ Equity } \\
\hline Common stock & 771,375 & $1,146,375$ & $\$$ & $1,736,250$ & $\$$ & $2,048,250$ & $\$$ & $2,259,825$ \\
\hline NREL grant & 375,000 & - & $\$$ & - & $\$$ & - & $\$$ & - \\
\hline Retained earnings & $(129,750)$ & $(122,815)$ & $\$$ & $(91,650)$ & $\$$ & $(40,225)$ & $\$$ & 53,815 \\
\hline Biodiesel product dividend & - & & $\$$ & 112,500 & $\$$ & 137,500 & $\$$ & 212,500 \\
\hline Wind farm REC product dividend & $\$$ & $\$$ & $\$$ & - & $\$$ & 62,500 & $\$$ & 62,500 \\
\hline Other & & $\$$ & $\$$ & - & $\$$ & - & $\$$ & - \\
\hline Total equity & $1,016,625$ & $1,023,560$ & $\$$ & $1,757,100$ & $\$$ & $2,208,025$ & $\$$ & $2,588,640$ \\
\hline Total liabilities \& equity & $1,016,625$ & $1,023,560$ & $\$$ & $1,757,100$ & $\$$ & $2,208,025$ & $\$$ & $2,588,640$ \\
\hline
\end{tabular}




\subsection{Pro Forma Member and Community Benefits}

\section{Table 5. Pro Forma Member and Community Benefits}

\begin{tabular}{|c|c|c|c|c|c|c|c|c|c|}
\hline Community Benefit & 2005-06 & & 2007 & & 2008 & & 2009 & & 2010 \\
\hline \multicolumn{10}{|c|}{$\begin{array}{l}\text { Here are some of the key numbers from the business plan. This is money kept in our community because Co-op Power and Northeast Biodiesel are locally-owned - owners and } \\
\text { workers live in our community - jobs and profits are here and stay here. This is money not going to support foreign oil: }\end{array}$} \\
\hline Accumulated $\mathrm{i}$ & 950,000 & $\$$ & $1,700,000$ & $\$$ & $1,700,000$ & $\$$ & $1,700,000$ & $\$$ & $1,700,000$ \\
\hline Accumulated investment in community wind farms or other sustainable projects $\$$ & 250,000 & $\$$ & 250,000 & $\$$ & 500,000 & $\$$ & $1,000,000$ & $\$$ & $1,500,000$ \\
\hline Money spent specifically on education, outreach and community building each year: $\$$ & 79,000 & $\$$ & 104,727 & $\$$ & 142,919 & $\$$ & 176,146 & $\$$ & 204,411 \\
\hline
\end{tabular}

We're building an engine for sustainable development rooted in our community. Please consider joining today! And help sign on new members in the next few months!

\section{Member Benefits}

Your member benefits will be based on how much you use the products and services Co-op Power provides. The more you use, the more you'll benefit.

(1) As a general rule, you will get a discount on products \& services you buy through Coop Power. Once we get over the start-up phase, our goal is an average of a $10 \%$ discount . Some products will be less, some will be more. This is a up-front benefit at the time of purchase. Below, we are using an assumption of $5 \%$ average discount in 2006 and $10 \%$ each year thereafter.

(2) ALSO, since you own the cooperative, you decide through the democratic membership process how profits should be used. Members can decide to reinvest co-op profits in projects they care about, or distribute all or a part of profits as patronage refunds paid out to members buying products or services through the cooperative.

In the business plan we are assuming members decide to pay out $50 \%$ of profits as patronage refund. The refund is proportional to how much you have bought through the

Based on these assumptions, here is how much you approximately would save at various levels of spending on clean energy products $\&$ services offered by the co-op:

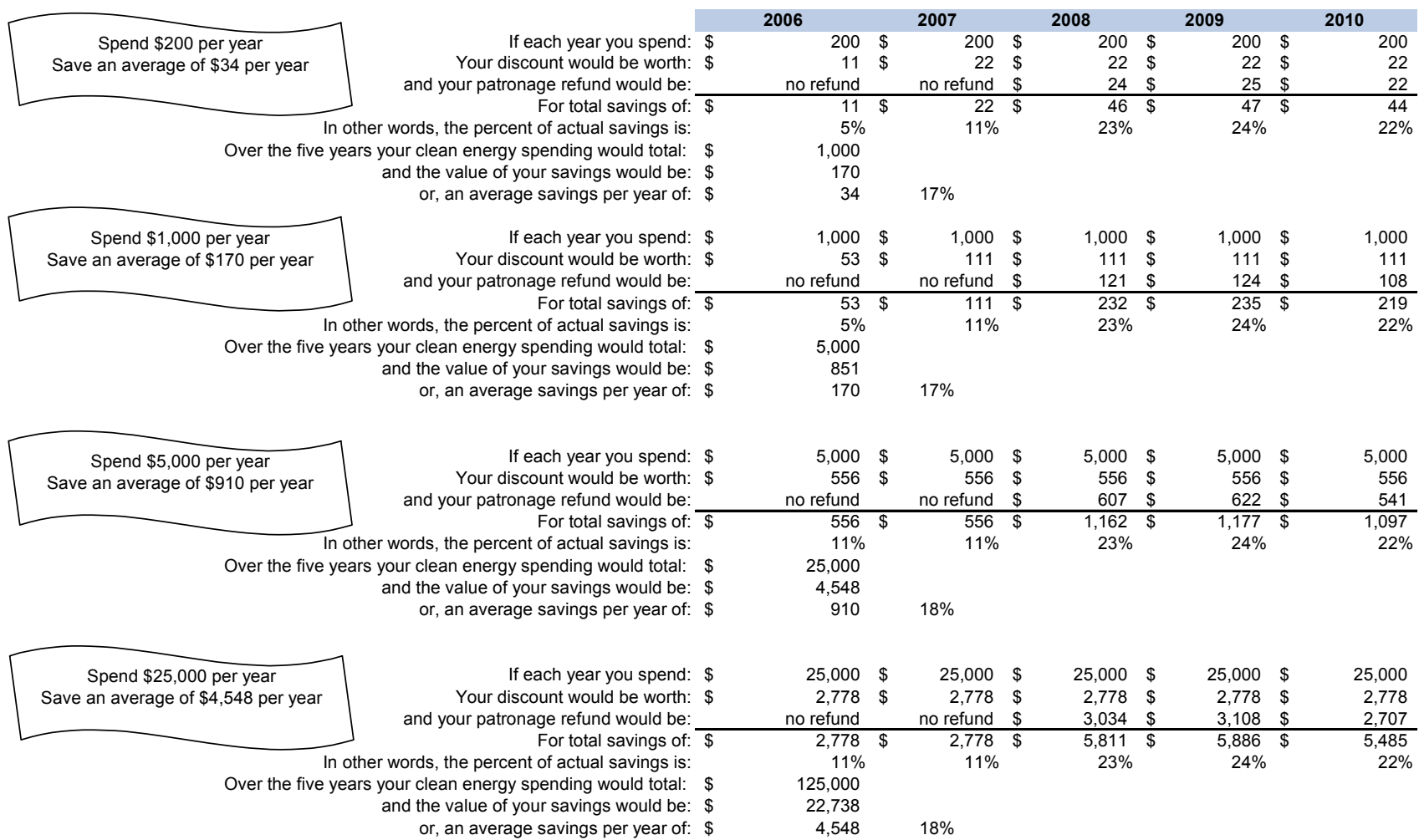




\section{Buying Renewable Energy Certificates to be a net-zero energy user}

$$
\begin{array}{lr}
\text { If your monthly electricity bill is approximately: } \$ & 50.00 \\
\text { You probably use around this many kWh monthly: } & 420 \quad \text { or per year: } \quad 5,040 \text { kWh }
\end{array}
$$

\begin{tabular}{|c|c|c|c|c|c|c|c|c|c|}
\hline If each REC is $2.5 \mathrm{c}$, this would cost you: $\$$ & 11 & & or per year: & $\$$ & 126 & & & & \\
\hline If we do the calculation on this annual spending: & 126 & $\$$ & 126 & $\$$ & 126 & $\$$ & 126 & $\$$ & 126 \\
\hline You'd save approximately this much in discount: & 6.30 & $\$$ & 6.30 & $\$$ & 6.30 & $\$$ & 6.30 & $\$$ & 6.30 \\
\hline And could get this much back in patronage refund: & - & $\$$ & - & $\$$ & 15 & $\$$ & 16 & $\$$ & 14 \\
\hline For total savings of: & $\begin{array}{c}6 \\
5.0 \%\end{array}$ & $\$$ & $\begin{array}{c}6 \\
5.0 \%\end{array}$ & $\$$ & $\begin{array}{r}22 \\
17.1 \%\end{array}$ & $\$$ & $\begin{array}{r}22 \\
17.4 \%\end{array}$ & $\$$ & $\begin{array}{r}20 \\
15.8 \%\end{array}$ \\
\hline
\end{tabular}

To entirely offset this electricity use, you would buy an equivalent number of RECs from Co-op Power, directly supporting a given wind farm, solar project, or other

Buying a home solar electric (photovoltaic) system

Let's say you buy a PV system from one of the local installers we have agreements with already today: If you buy a $2 \mathrm{~kW}$ solar system, you would pay upfront:
But, right now, the state would give you an incentive of approximately: So, you actually only would pay:

Your Coop Power discount on top of that would be:

19000

7000 (the incentive will be less over time - act now!) 12000

380

Note: The numbers here reflect the base offer we already have in place today, but, if you read the business plan, you will see that we have ideas for how to further improve the savings for members installing solar systems. We think the membership benefit will be higher. However, what we show here, is what we can guarantee from the start.

Buying biodiesel for your diesel vehicle

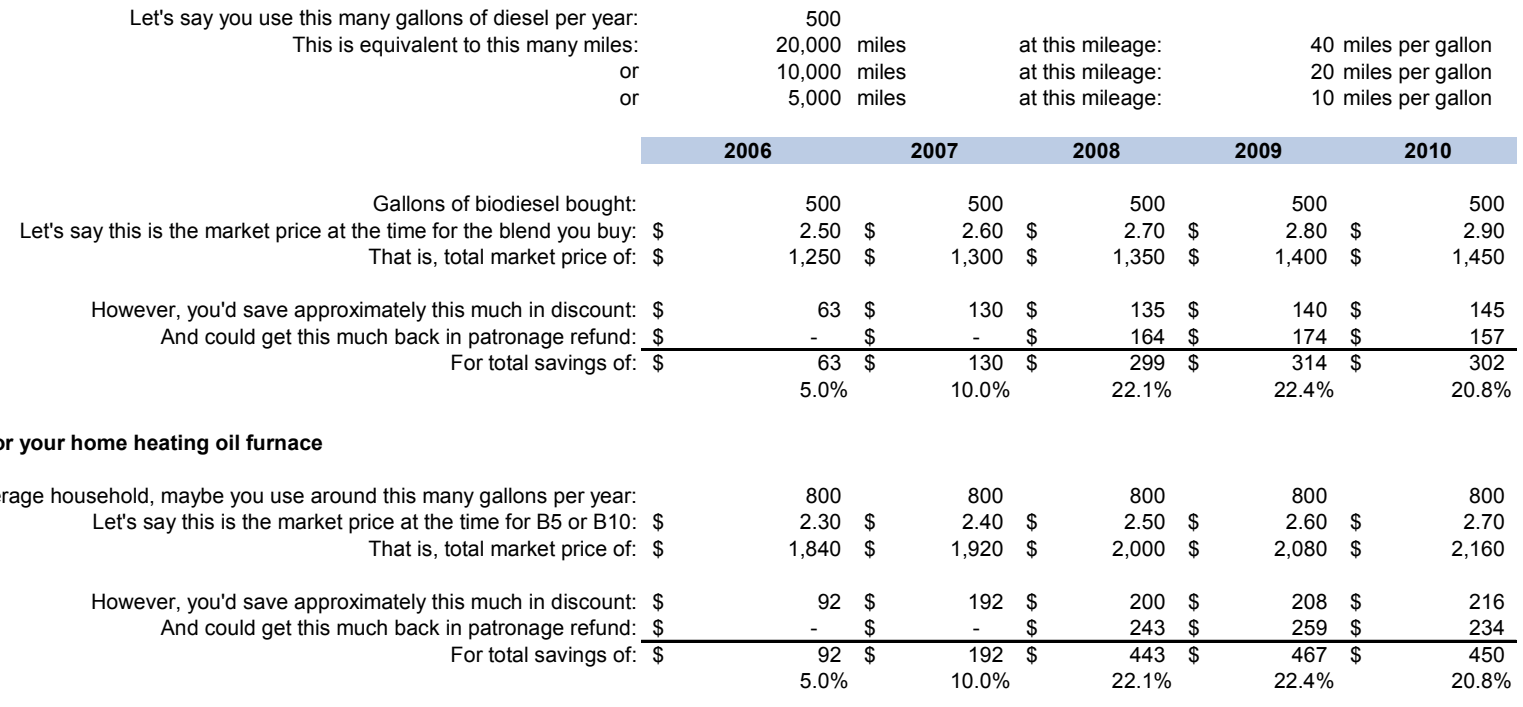

By installing a solar system, you would immediately earn back more than a third of the cost of your membership sign-up

$20.8 \%$

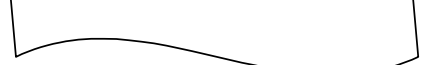




\section{Co-op Power Interim Management}

\subsection{Lynn Benander, Interim Manager, Co-op Power}

lbenander@cooplife.coop, (413) 552-6446

Lynn Benander provides interim management services to three-four cooperative development projects each year by providing start-up management services. She is the chief executive officer of Cooperative Life, the Northeast's Federation for Cooperatives. Cooperative Life works with cooperative leaders and community-based organizations to build the cooperative economy in New England and New York. She has a passion for building member-owned and -controlled businesses that strengthen local economies. She has supported the development of consumer-, producer-, and worker-owned cooperatives in the region, primarily in the

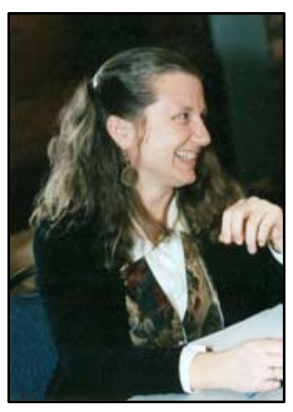
energy and food industries. Working with a strong staff, Ms. Benander has raised more than $\$ 16$ million in development grants and financing for cooperative development and provided strategic planning and technical assistance support to hundreds of cooperative development projects in the Northeast.

She has lead the development of national cooperative education and training programs such as Marketing Our Cooperative Advantage, Effective Board Leadership, Making Cooperative Membership Meaningful, and A Technical Course on Cooperative Development for people interested in starting a cooperative. Ms. Benander developed and ran a national professional development certificate training program for cooperative development centers in the United States for 4 years. She has developed a Web resource for building democracy within cooperatives and assisted groups with online facilitation. She has served on numerous cooperative and community boards and on her town's finance committee.

\subsection{Christian Lagier, Interim Manager, Co-op Power} clagier@cooppower.coop, (413) 268-7009

Christian Lagier has an established track record in entrepreneurship, sales, and strategic business development in the United States and Europe. He has particularly valuable experience related to the energy sector and renewable energy. Christian Lagier is passionate about the values and benefits of cooperative ownership structures. Today, he applies his broad experience to helping cooperatives in the northeastern United States expand their membership base and reach multiple bottom-line goals. He is especially focused on developing and executing new cooperative business ideas.

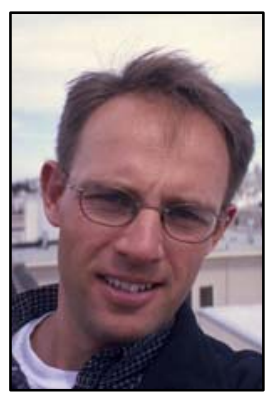


Until recently, Mr. Lagier worked for Northern Power Systems of Vermont, the oldest renewable energy company in the United States. He opened the San Francisco office and established operational infrastructure and pursued new strategic goals for Northern Power Systems, primarily related to the development of solar, wind, cogeneration, and hydrogen projects. During his time with Northern Power Systems, Mr. Lagier also supported strategy development for Distributed Energy Systems Corp. and Proton Energy.

Prior to Northern Power Systems, Christian Lagier served as director for Proxicom, a leading consulting partner for Global 1000 companies. He was an important contributor to Proxicom's growth from 15 to 1,500 employees, negotiated contracts up to $\$ 10$ million, grew the Energy Practice working for clients such as Pacific Gas and Electric, and established the Paris office. He worked for the international Management Consulting Group of TRW Inc. before joining Proxicom. Mr. Lagier began his entrepreneurial and consulting career 15 years ago in Denmark, the land of co-ops and wind turbines. He speaks six languages and completed his business administration studies in Denmark, Brussels, and France. He has a master's degree in economics and business administration from Copenhagen Business School. 


\section{Co-op Power Board of Directors}

David Biddle (chair) of Hatfield is a founder of the Pioneer Valley Biodiesel Cooperative. He has a doctorate in Arabic and Middle Eastern History; is fluent in Spanish, French, and Arabic; and was a professor at the University of Massachusetts until 1976. He then worked in the field of artificial intelligence for 15 years. David is now involved in construction, real estate management, and renewable energy.

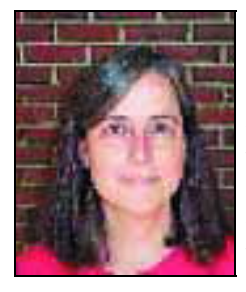

Lynn Di Tullio (clerk) is a consultant on renewable power and energy efficiency. Prior to forming her consultancy, The WinterGreen Group, she was president of Ewing Controls Inc., an engineering firm that specializes in customized controls and electrical interconnection switchgear for distributed power generation. Prior to that, she was president of Trigen Ewing Power, an integrator of steam turbine-driven power generation systems, in Turners Falls, Massachusetts. Since 1987, she has been involved in the development of industrial and commercial power generation systems. Lynn is a registered professional engineer in Massachusetts and has published articles on energy efficiency and steam turbine cogeneration for industry journals.

Erik Hoffner (treasurer) is trained as a photographer, educator, and organic farmer. He has worked in the environmental field throughout the western United States and is currently a writer and outreach coordinator for Orion magazine, "America's finest environmental magazine" (Boston Globe), and overall winner of the 2004 Independent Press Awards. As chair for the Pioneer Valley Biodiesel Cooperative, he guided the formation of the biodiesel production facility.

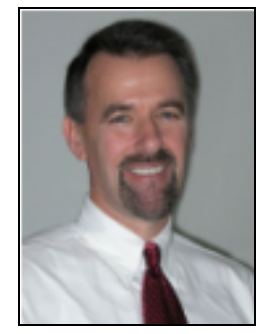

Tim Rice is the third generation of the Rice family to run Rice Oil, a familyowned local distributor of energy products that employs 250 people in New England. Tim Rice was schooled in Greenfield. He spent 2 years at Northfield Mount Hermon and completed college at Colby College. Prior to coming to Rice, Tim worked for 5 years at Codex Corp., a subsidiary of Motorola Inc. in Mansfield, Massachusetts. He has been married to Elise for 16 years.

Sally Wright is a licensed engineer with more than 10 years of experience in power engineering. Her focus is renewable electricity and energy conservation. She currently provides technical support to Massachusetts' communities that want to own community-scale wind power. She works at the Renewable Energy Research Laboratory at the University of Massachusetts at Amherst.

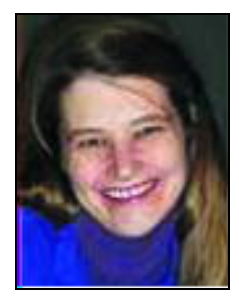


Appendix B. Biodiesel Production Facility Business Plan 
B-ii 


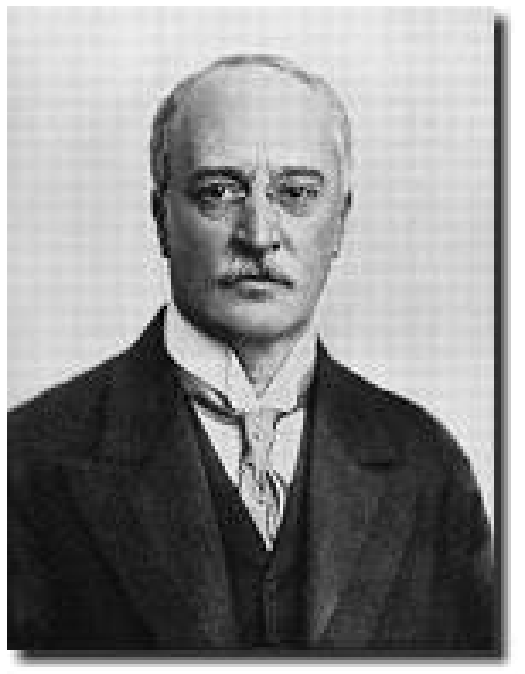

"The use of vegetable oils for engine fuels may seem insignificant today, but such oils may become, in the course of time, as important as petroleum and the coal-tar products of the present time ....

"Motive power can still be produced from the heat of the sun, always available, even when the natural stores of solid and liquid fuels are completely exhausted."

— Rudolph Diesel, inventor of the diesel engine, in a speech on April 13, 1912 


\section{Acronyms}

$\begin{array}{ll}\text { CEO } & \text { chief executive officer } \\ \text { EPAct } & \text { Energy Policy Act } \\ \text { FOB } & \text { free on board } \\ \text { HHO } & \text { home heating oil } \\ \text { NDA } & \text { non-disclosure agreement } \\ \text { RVO } & \text { recycled vegetable oil }\end{array}$

B-iv 


\section{Executive Summary}

Co-op Power is building and operating a biodiesel production facility in Western Massachusetts that will initially produce 2 million gal/yr and expand to 10 million gal/yr by October 2006. This facility will be the first of its kind in the Northeast. The initial phase of this project is to develop a medium-scale, modular production facility that uses locally available feedstock to serve the needs of the Northeast's heating oil and diesel fuel markets. The expanded facility will most likely use production methodologies prevalent in larger-scale facilities. The planned initial production start-up is September of 2005, with a 3-month ramp to an initial full capacity of $85 \%$ ( 1.7 million gal $/ \mathrm{yr}$ ) of installed annual capacity. We will begin the expansion project in June 2006, with a target production start of October 2006.

This business will be launched with an initial capital structure of $\$ 2.5$ million of equity and $\$ 1.1$ million of long-term debt for a total capitalization of $\$ 3.6$ million. This will provide the required capital for site acquisition, any required site improvements, and equipment purchase and installation as well as $\$ 450,000$ of working capital. The planned 2006 expansion to 10 million gal/yr will require an additional $\$ 8$ million in capital, $\$ 6$ million in long-term debt, and $\$ 2$ million in equity. The base-case plan shows that the business will be operated at a profit beginning with the second year of operations (2006), with a "total" return on average equity through 2009 of more than $30 \%$.

The basic launch strategy is to focus on wholesale supply of biodiesel ( $95 \%$ of production capacity), targeted primarily, but not exclusively, to home heating oil dealers that will, in turn, blend our product with conventional No. 2 home heating oil ( $2 \%-3 \%$ blends) as a product differentiator. This strategy has been adopted to:

1. Minimize marketing cost A large portion of plant capacity can be sold to a few (20-30) large home heating oil dealers with a direct sales approach.

2. Minimize production volume variability Selling annual supply contracts to large-volume users provides more predictability of capacity use.

3. Minimize product quality risks.

Targeting low-percentage blends eliminates weather and batch-to-batch variability issues in the early stages of operation.

Entry into the on-road diesel fuel market is predicated on the June 2006 implementation of extra-low-sulfur content requirements for diesel fuel. The home heating oil and on-road diesel fuel markets for the Northeast are 5.2 billion and 4.2 billion gal/yr, respectively. The biodiesel production facility's planned production capacity represents the following percentages of Northeast markets for home heating oil and on-road diesel fuel at $2 \%-3 \%$ blends: 


\title{
Biodiesel Market Penetration Requirements
}

(at initial production capacity of 1.7 million gal and expanded capacity of 8.5 million gal)

\section{Home Heating Oil Market}
Northeast
$1 \%$ of initial capacity
(Within 300-mile radius)
$5.4 \%$ of expanded capacity
Massachusetts
$6 \%$ of initial capacity
(Within 100-mile radius)
$32 \%$ of expanded capacity

\section{On-Road Diesel Fuel Market}

\author{
Northeast \\ $2 \%$ of initial capacity \\ (Within 300-mile radius) \\ $7 \%$ of expanded capacity \\ Massachusetts \\ $21 \%$ of initial capacity \\ (Within 100 mile radius) \\ $71 \%$ of expanded capacity
}

We have planned a small retail pilot strategy, with $5 \%$ of production capacity targeted at onroad and off-road diesel-powered vehicles. This pilot retail operation is designed to identify the most appropriate market segments, marketing channels, and distribution methodologies for successful implementation of a larger retail strategy. The pilot retail operation will develop a packaged product offering that consists of 55-gal and 5-gal containers for distribution by local retailers (e.g., marine supply stores such as West Marine; hardware stores such as Aubuchons, Ace Hardware, and Home Depot; and farm supply stores).

The facility size was based on an assessment of available feedstock and our assessment of our ability to penetrate the Northeast's home heating oil and diesel fuel markets. Our proposed production facility will initially require 1.8 million gal of feedstock annually, which represents $28 \%$ of the used vegetable oil disposed of in Massachusetts and 3\% of the used vegetable oil disposed of in the Northeast within a 300-mile radius of Greenfield, Massachusetts. The capacity expansion will multiply the feedstock requirements by a factor of five, which represents more RVO than is currently available in Massachusetts and $15 \%$ of the available RVO in the Northeast.

Used vegetable oil will be collected from restaurants, cafeterias, and other food processors. The cost of the used vegetable oil feedstock is a primary determinant of the profitability of the operation. Three strategies are proposed to obtain the required feedstock quantities:

1. Local farmers back-haul RVO from Boston and New York City.|

2. Grease is collected by independent contractors (36\% dropping to $27 \%$ of requirements).

3. Bulk "untreated" RVO is collected by collection companies ( $64 \%$ growing to $73 \%$ of requirements). 
Grease collection by independent contractors and back-hauling from Boston and New York City are the most cost-effective collection strategies. Given that the infrastructure for these strategies does not exist, our plan contemplates growth over time for these efforts, with the primary focus on the farmer back-haul strategy. These farmers have been looking for a costeffective way to get produce, livestock, and other goods to the more lucrative markets in Boston and New York City. If they back-haul grease, we believe the economics of delivering to these markets will become attractive to Western Massachusetts farmers.

We expect that grease farming will be significantly difficult, and therefore, our primary strategy will be focused on bulk purchases. The strategies for bulk purchases are to:

1. Buy bulk "untreated" RVO from existing collection companies

2. Develop a virgin oil distribution business in which the biodiesel production facility retains ownership of the soy or canola oil and leases its use to the foodservice industry, thus providing a guaranteed source of RVO. (This strategy is under development and is not reflected in this version of the plan.)

The biodiesel production facility will select a biodiesel production technology that satisfies our criteria of cost-effectiveness, flexibility, and schedule requirements. Our choice of process technology will provide a medium-scale plant that uses used vegetable oil as a feedstock.

Biodiesel is a locally produced, renewable fuel that has significant environmental benefits. It is safe and biodegradable, and it reduces serious air pollutants such as soot, particulates, carbon monoxide, hydrocarbons, and air toxins. A 1998 National Renewable Energy Laboratory study concluded that the use of $100 \%$ biodiesel reduces carbon dioxide emissions by more than $75 \%$ over petroleum diesel. Using a blend of $20 \%$ biodiesel reduces carbon dioxide emissions by $15 \%$. The stress on landfills is also reduced as recycled vegetable oil is removed from the waste stream. Using biodiesel also reduces dependence on foreign oil and supports local economies. 
B-viii 


\section{Table of Contents}

List of Figures

List of Tables

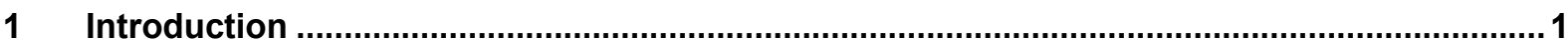

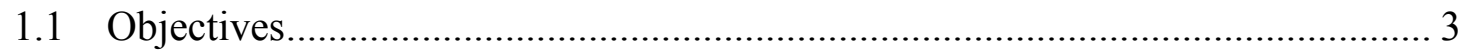

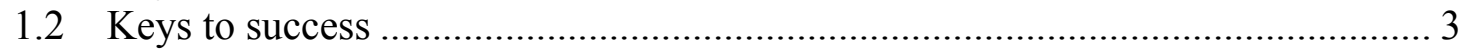

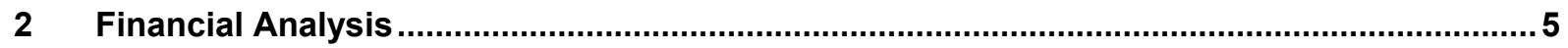

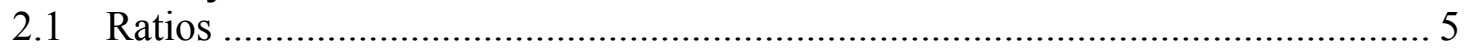

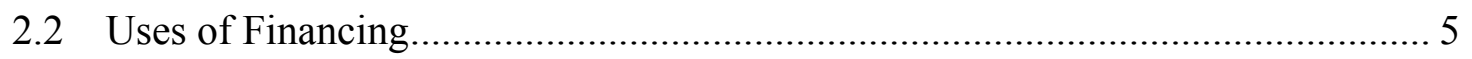

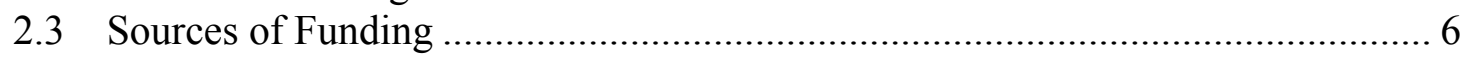

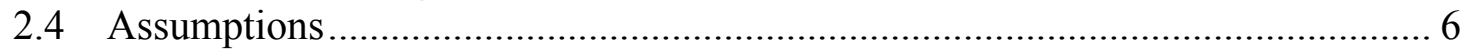

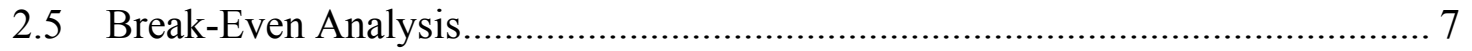

2.6 Critical Factors ................................................................................ 7

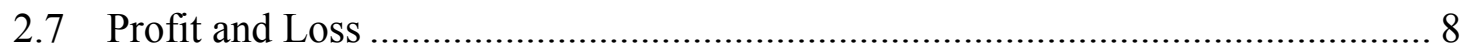

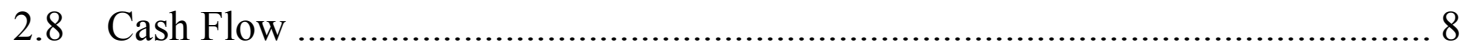

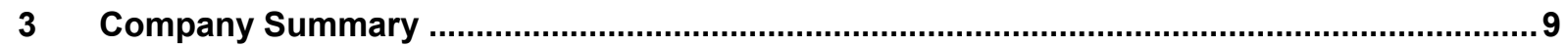

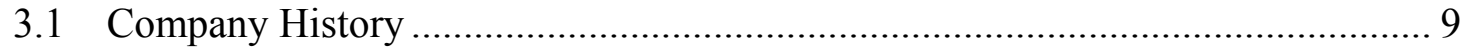

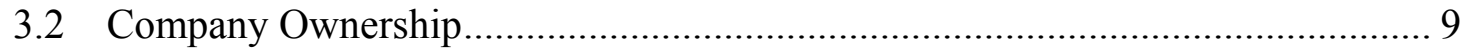

3.3 Company Locations and Facilities ............................................................ 10

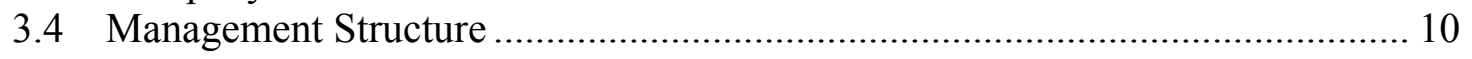

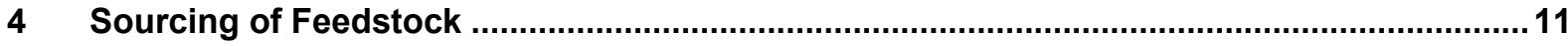

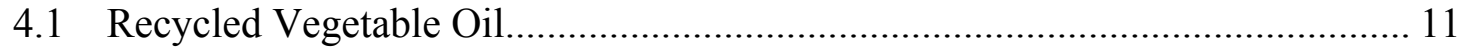

4.2 Methyl Alcohol ....................................................................................... 13

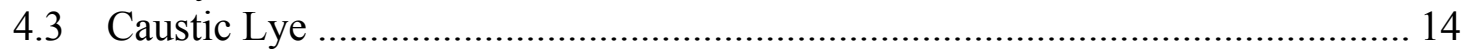

4.4 Sulfuric Acid ........................................................................................ 14

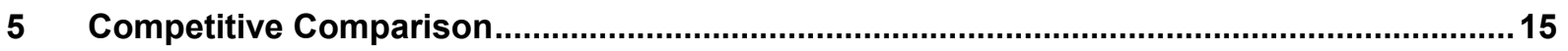

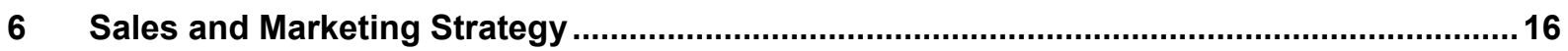

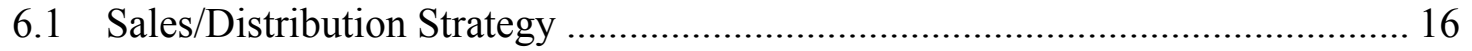

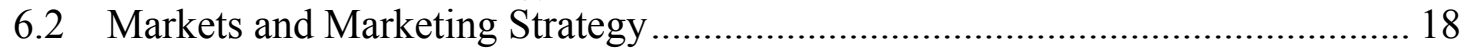

6.3 Wholesale B-100 Product Pricing .................................................................... 23

6.4 Retail Pricing............................................................................................... 24

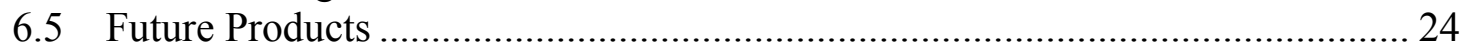

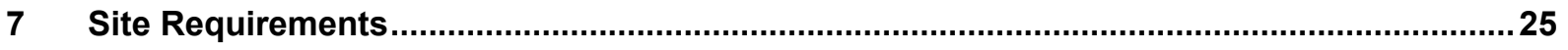

$8 \quad$ Technology

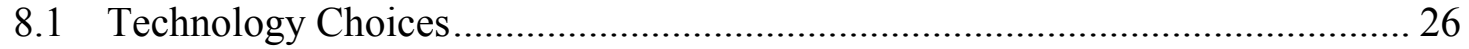

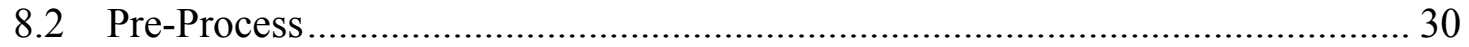

8.3 Process ................................................................................................ 31

8.4 Quality Control and Quality Assurance Program ....................................... 31 


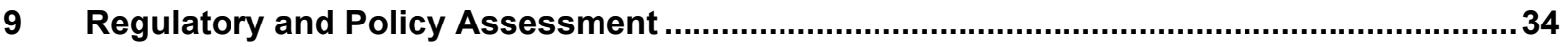

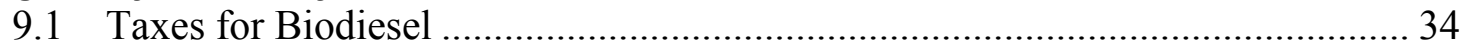

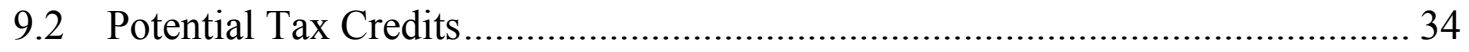

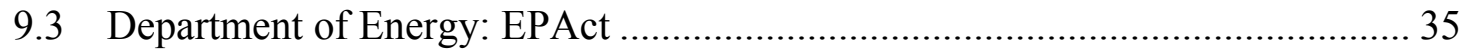

9.4 U.S. Environmental Protection Agency .......................................................... 36

9.5 U.S. Department of Agriculture ................................................................ 37

9.6 Massachusetts Department of Environmental Protection ................................. 37

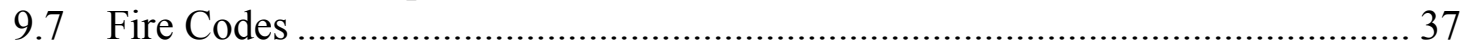

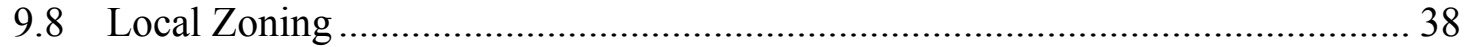

9.9 Legal Implications: Liability Considerations.......................................... 38

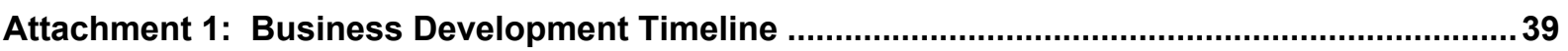

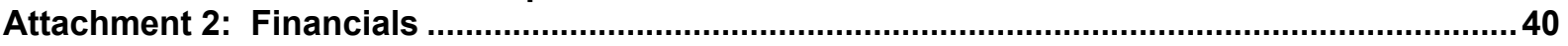

Attachment 3: Population of New England, New York, New Jersey, Pennsylvania ....................52

Attachment 4: Recycled Vegetable Oil Resources (Restaurants and Cafeterias Within a 60-Mile Radius of Greenfield, Massachusetts) ...................................................53

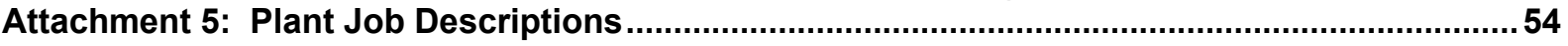

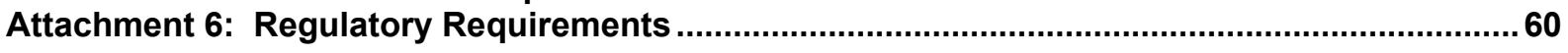




\section{List of Figures}

Figure 1. The biodiesel production facility organizational chart ...................................... 10

\section{List of Tables}

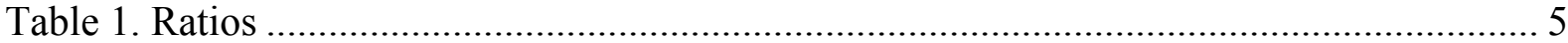

Table 2. Break-Even Production ...................................................................................... 7

Table 3. Feedstocks Purchased From Collecting Companies or Rendering Companies ......... 13

Table 4. Home Heating Oil Market in Gallons/Year (as Estimated by Local HHO Dealers) . 19

Table 5. Home Heating Oil Usage in Gallons per Year (based on EIA data)........................ 20

Table 6. No.2 Transportation Fuel in Gallons/Year............................................................. 21

Table 7. Potential Fleet Fuel Market Based on Existing Usage........................................... 22

Table 8. Projected Average Wholesale Price/Gallon .......................................................... 23

Table 9. Projected Average Retail Price/Gallon On-Road................................................. 24

Table 10. Commercial Biodiesel Technologies Available, 2004 ...................................... 28

Table 11. Technology Choice Decision Matrix ...................................................................... 30

Table 12. Detailed ASTM Requirements for Biodiesel (B-100) D-6751 ............................. 32

Table 13. Process Control Tests........................................................................................... 33 
B-xii 


\section{Introduction}

Biodiesel is a new fuel, and the public is still learning about its qualities and uses. With a new, multi-million-dollar national marketing campaign initiated by the National Biodiesel Board, it is rapidly gaining acceptance and market share in the Northeast despite its high price. Like premium gasoline, biodiesel is a premium fuel that offers good value for the incremental cost.

Biodiesel is a remarkably versatile fuel that is quite unlike anything else in common use. Its inherently safe nature, high flash point, low toxicity, biodegradability, and stability make it safer than other fuels or solvents. Biodiesel is appropriate for all diesel cars and trucks that have been properly modified and superior in almost every aspect to petroleum diesel fuel. It can also be used as an off-road fuel to yield marked improvements in the environmental acceptability of construction and farming equipment. In addition, biodiesel works as a heating fuel in standard equipment, and it has excellent applications in marine use because of its markedly lower toxicity.

Biodiesel can be used in any modified diesel engine in its pure form (i.e., "neat," or B-100) or in unmodified diesel engines if it is diluted appropriately with petroleum diesel fuel. Biodiesel fuel goes into the standard fuel tank - unlike "grease conversions" that have been promoted locally. Minor modifications to the fuel system may be required if B-100 is used.

Nationally, the most frequently sold form of biodiesel fuel is called B-20. It is made by mixing standard diesel fuel with $20 \%$ neat biodiesel by volume. This mixture has been demonstrated to have the fewest problems with clouding and solidifying in cold weather and other operational challenges. There are more than 250 retail locations for biodiesel in the United States. Distributors make this fuel available in most parts of the country.

Biodiesel is perhaps the "greenest" of the liquid fuels available at this time. U.S. governmentcertified results show B-100 biodiesel reduces soot and unburned hydrocarbons by nearly $60 \%$, depending on the engine tested. In addition, global warming exhaust gasses are reduced by almost $90 \%$, exhaust carcinogenicity is reduced by more than $90 \%$, and acid rain-causing sulfur is reduced by almost $100 \%$.

The proposed production from the biorefinery will reduce carbon dioxide in the atmosphere by more than 20 million lbs/yr compared with standard diesel fuel. Biodiesel made from recycled vegetable oil (RVO) has all the benefits of standard biodiesel, and it has superior return on the energy invested and numerous other environmental benefits because of its recycled base material. Biodiesel use studies have documented reduced engine wear, increased lubricity of fuel, and reductions in engine noise. The overall engine performance in power output using B-100 is slightly less than No. 2 diesel fuel, reducing power, torque, and fuel economy by $8 \%$. 
Studies from the National Renewable Energy Laboratory and others demonstrate an energy return on the energy invested for biodiesel of $320 \%$. This energy return on the energy invested is far better than that of any other liquid fuel. Because the proposed biorefinery will itself be biodiesel-operated (which effectively eliminates fossil fuel input requirements), our production facility will further improve on this value.

The biodiesel industry is growing rapidly because of worldwide appreciation and acceptance of biodiesel's qualities and its benefits over standard diesel fuel. In the United States, 21 plants are producing biodiesel, but none of these is within the Northeastern United States or Canada. This is largely due to the predominance of virgin soybean oil as a feedstock in biodiesel production in the Midwest and far West to date. This is not economically attractive in the Northeast or Canada.

In New England, there is an abundance of RVO from restaurants, which currently pay to dispose of this waste. Biodiesel from RVO is equivalent to biodiesel made from other source materials and is superior in performance in terms of tailpipe emissions and product stability (Mustafa 2003; National Biodiesel Board).

National production of biodiesel grew from 1 million gal/yr in 1997 to 7 million gal/yr in 2000 and 25 million gal/yr in 2003. The U.S. Department of Energy projected sales to increase to more than 35 million gal/yr in 2004-a 40\% increase. In 2002, World Energy Corp., a distributor based in Chelsea, Massachusetts, reported sales of 600,000 gal in New England.

The biodiesel production facility will use recycled fryer oil, known as "yellow grease" or RVO. This feedstock will provide several benefits to the community. It will:

1. Reduce landfill waste

2. Reduce disposal costs for restaurant owners

3. Decrease illegal disposal

4. Increase local employment by providing high-paying manufacturing jobs

5. Reduce demand for petroleum to be drilled, transported, and imported.

It keeps more money circulating in the local community and country while restoring manufacturing jobs for the area. Using locally produced waste, the biorefinery can reduce dependence on fossil fuels and displace approximately 1,615,000 gal of petroleum at the proposed initial operating level.

Based on price factors and the availability of regional feedstocks, RVO is the only option that can make a biorefinery of this scale profitable in the Northeast. RVO is currently less than half the cost of virgin soybean oil on the open market and about one-third less than animal fatbased feedstock. Although the proposed biorefinery design can convert virgin vegetable oil and other potential feedstocks such as brown grease or tallow, the economics of those options indicate they will not be a large part of the initial plan for operation. 
Proposed biodiesel refineries in North America are incorporating a growing percentage of RVO in their development plans, but they may be limited by the availability of this resource in their areas. Sufficient RVO appears to be available in the Northeast, with significant resources within a 60-mile radius of the plant (see Attachment 4: Recycled Vegetable Oil Resources). The National Renewable Energy Laboratory reported in the "Urban Waste Grease Resource Assessment" that there is approximately 1.1 gal of collectable RVO per person per year. ${ }^{1}$ According to the National Renewable Energy Laboratory study, approximately 6.5 million gal of RVO are generated in Massachusetts yearly.

If only about one-third of the regional RVO resource is collected for biorefinery operation in a given area, it will require a population of just less than 5 million people to produce sufficient feedstock for our initial production. If collection constraints and competition with other RVO collectors prevents us from securing all our feedstock within Massachusetts, there is sufficient RVO produced within a 130-mile radius of our facility to meet production demands (see Attachment 3: Population: New England, New York, New Jersey, Pennsylvania). The relevant issue is price.

\subsection{Objectives}

The objectives of the biodiesel production facility are to:

- Establish a Western Massachusetts-based biorefinery to provide biodiesel fuel to local New England markets

- Develop a business and production model for community ownership of a biorefinery

- Grow the markets for biodiesel in the Northeast

- Expand this concept into Mid-Atlantic and Southeastern markets.

\subsection{Keys to success}

There are five keys to success for this project. The keys are to:

1. Meet ASTM D6751 standards

Meeting ASTM D6751 standards for the output of the production facility is essential. Meeting ASTM standards is a pre-requisite of validating our product for all potential customers. This is an area of risk for the project, and it is being precluded by contracting for the purchase of already proven technology that has demonstrated compliance with ASTM D6751.

\footnotetext{
1 “Urban Waste Grease Resource Assessment.” NREL/SR-570-26141. National Renewable Energy Laboratory: Golden, CO. November 1998.
} 
2. Speed production ramp-up time

Production ramp-up time is a key success factor because:

- We are pre-selling product; therefore, a faster production ramp-up allows us to meet our initial sales commitments with greater certainty.

- Our unit cost, and therefore margins and profitability, are production volumedependent.

3. Obtain planned market penetration levels

The success of our sales and market efforts will determine whether we can increase the capacity of our production facility and therefore reduce our unit cost in anticipation of potential new and larger facilities being constructed in the Northeast.

4. Manage feedstock availability and cost

At $65 \%-70 \%$ of the cost of goods sold, feedstock is the single largest component. Our success in building the "grease farmers" and negotiating long-term supply agreements with rendering companies will ultimately determine the success or failure of this project. Our primary advantage over the competition is our planned use of "raw" RVO collected from restaurants and cafeterias and collected by rendering companies under contract (rather than the use of bulk purchases of processed RVO from rendering companies).

5. Obtain feedstock market penetration rates.

Obtaining feedstock market penetration rates is critical because supply availability will be crucial as new players enter the market and our ultimate production capacity is limited by feedstock supply. 


\section{Financial Analysis}

The pro forma financials for the proposed RVO-based biodiesel production biorefinery indicate potential for profitable operation with strong cash flow. Attaining profitability is highly dependent on the our ability to reach scale in terms of production capacity and procure increasing amounts of yellow grease at an affordable cost. Sustained profitability is projected to occur the second year of operations. Although the business will require working capital (approximately $\$ 450,000$ ) for credit support during its start-up period, projections indicate a strong cash flow once the business is established. Cash flow and profitability should be strong enough to offer a dividend to members or equity investors within 3 years of start-up.

\subsection{Ratios}

Equity investment $=\$ 2.5$ million initially $+\$ 2.0$ million in 2006

Payback on initial investment $<3$ years

Total return on average equity $=34.79 \%$ through 2009

Table 1. Ratios

\begin{tabular}{lrrrrr}
\hline & $\mathbf{2 0 0 5}$ & $\mathbf{2 0 0 6}$ & $\mathbf{2 0 0 7}$ & $\mathbf{2 0 0 8}$ & $\mathbf{2 0 0 9}$ \\
\cline { 2 - 6 } & & & & & \\
Debt/Equity & $47 \%$ & $131 \%$ & $52 \%$ & $31 \%$ & $20 \%$ \\
Gross Margin & $-14 \%$ & $40 \%$ & $44 \%$ & $43 \%$ & $43 \%$ \\
Net Margin & $-134 \%$ & $24 \%$ & $34 \%$ & $32 \%$ & $33 \%$ \\
Return on Avg. Equity & $-36 \%$ & $24 \%$ & $38 \%$ & $18 \%$ & $14 \%$ \\
Return on Invest Capital & $-19 \%$ & $57 \%$ & $127 \%$ & $100 \%$ & $104 \%$ \\
Asset Turnover & .18 & .47 & .64 & .48 & .39 \\
Debt Serv Coverage(Cash) & $\mathrm{N} / \mathrm{A}$ & 1.17 & 6.02 & 5.70 & 5.72 \\
\hline
\end{tabular}

\subsection{Uses of Financing}

The project initially requires approximately $\$ 3.6$ million in financing. Approximately $\$ 1.5$ million is for purchase and construction costs of the processing plant. The remaining $\$ 2.1$ million includes the projected costs for the site, site improvements, and the equipment required for the automated collection and drum-cleaning system as well as start-up costs, working capital, an a $15 \%$ contingency. ${ }^{2}$ The working capital required is based on the cash required for supplier credit support (letters of credit or bonds) at $80 \%$ of maximum monthly feedstock cost.

\footnotetext{
${ }^{2}$ Capital cost estimates are based on published equipment vendor estimates of equipment cost per gallon of production capacity, project development budgets, and working knowledge of the cost of the equipment required in a manufacturing operation.
} 


\subsection{Sources of Funding}

The project has assumed an initial financing structure debt-to-equity ratio of $40 \%$. This provides the business with sufficient working capital for the start-up period. The initial equity $(\$ 750,000)$ is projected to come from Co-op Power and includes a United States Department of Agriculture grant of $\$ 250,000$. The balance of the equity (Class B preferred stock) will come from qualified private investors, some of whom have already been identified. Dividend payments of $21.5 \%$ per year are planned by the third year of operation. At that time, the value of the business will have increased. It is contemplated that the biodiesel production facility will call the Class B preferred stock in the years 2011-2015.

\subsection{Assumptions}

The assumptions used in the financials are detailed in Attachment 2. Costs of goods are based on past experience. All other fixed cost estimates are based on the author's general knowledge of the requirements of start-up operations. Further refinement may be needed.

Because the facility, the business, and the product are all new to the New England marketplace, we believe we have assumed sufficient management for the business. This includes the following staffing requirements:

- One full-time president and general manager (see Attachment 5 for job description)

- One full-time vice president of operations (see Attachment 5 for job description)

- One full-time production/quality manager (see Attachment 5 for job description)

- One full-time production assistant

- One full-time RVO receiving assistant

- One half-time customer service and clerical support person.

Marketing, advertising, legal, and accounting services are all expected to be subcontracted. The facility/land lease or purchase will be for approximately $10,000 \mathrm{ft}^{2}$ in an industrially zoned space. Several appropriate spaces have been identified in the region.

The wholesale selling price used in this business plan has been established as the lesser of $\$ 2.10 /$ gal or total cost (fixed and variable) plus a $\$ 0.65 /$ gal markup. This pricing strategy will yield a competitive wholesale price in Year 1, 2005, at \$2.10/gal and provide significant pricing flexibility thereafter with the $\$ 0.65 /$ gal markup strategy. The discount from the current lowest cost on the East Coast has been established to (1) provide an incentive for distributors to buy from us and (2) address the market perception that RVO biodiesel is somehow less desirable that virgin vegetable oil biodiesel. We expect that this bias will disappear with greater acceptance and widespread use of RVO biodiesel. Although increased availability of biodiesel in the northeast could lower prices, we believe that concerns about fuel supply and public health issues associated with petroleum diesel as well as the incentives for renewable fuels will allow prices to remain at these levels or higher for the foreseeable future. 


\subsection{Break-Even Analysis}

The varying costs and availabilities of feedstock result in different levels of "break even" at different production capacities. The break-even analysis (see Attachment 2: Financials) assumes availability of up to 1.7 million gal of grease-farmed feedstock. Break-even production with these assumptions (two batches per day, 5 days per week) is shown at various production volumes in Table 2.

Table 2. Break-Even Production

\begin{tabular}{cccc}
\hline $\begin{array}{c}\text { Capacity } \\
\text { Level }\end{array}$ & $\begin{array}{c}\text { Production } \\
\text { Volume }\end{array}$ & $\begin{array}{c}\text { G } \\
\text { Grease-Farmed/ } \\
\text { Back-Hauled Feedstock }\end{array}$ & $\begin{array}{c}\text { Break-Even } \\
\text { Wholesale Price }\end{array}$ \\
\cline { 2 - 4 } $60 \%$ & $1,248,000$ & $50.4 \%$ & $\$ 1.54$ \\
Planned - 85\% & $1,768,000$ & $45.9 \%$ & $\$ 1.38$ \\
$100 \%$ & $2,080,000$ & $44.3 \%$ & $\$ 1.32$ \\
\hline
\end{tabular}

The break-even analysis shows break-even calculations for various other scenarios (e.g., a 6day week, 10 million gal/yr, and one batch per day).

\subsection{Critical Factors}

Sensitivity analyses were conducted for scenarios with varied sources of feedstock, higher and lower prices, full wholesale sales, increased retail sales, varied service charges for collection, royalty fees to technology suppliers, and higher loan rates.

The biggest factor affecting profitability and the return on investment is the cost and availability of the used grease feedstock. The facility proposes to use three methods to collect grease:

1. Independent contractors and farmer partners collect and deliver of grease at an estimated cost of \$0.30/gal ("grease farming").

2. Rendering companies and others sell "cleaned" grease from at an estimated cost of $\$ 0.80 /$ gal delivered.

3. Farmers back-haul grease from Boston and New York City after making their deliveries.

The financial projections require the development and growth of a number of independent contractors, or "grease farmers," to supply the production center. This grease farming industry is projected to initially supply 7,000 gal of recycled grease per month. This is expected to grow to more than 150,000 gal per month 3 years after start-up. 
Although the market information and National Renewable Energy Laboratory studies suggest the ready availability of this quantity of grease in the region, it remains to be seen whether our projected economics for a subcontracted collection service are sufficient to induce participation among potential independent contractors, farmers, restaurants, and cafeterias. For this reason, we have prepared a worst-case profit-and-loss scenario (see Attachment 2: Financials).

The worst-case scenario has three basic assumptions:

- Grease farming does not occur at the projected levels (or one-half of the projected level)

The business will be obligated to purchase larger quantities of feedstock from rendering companies. An alternative approach is to tie the increases in production to the availability of collected and farmed grease, thereby reducing the need to purchase the more expensive rendered grease, but this limits profitability.

- The price for purchases from rendering companies is projected at $\$ 1.21 / \mathrm{gal}$.

- Production start-up is delayed until January 2006.

The worst-case scenario still indicates that, given the planned volumes and our pricing methodology, the business is profitable beginning in 2007.

\subsection{Profit and Loss}

The operation is projected to reach profitability in the fifth month following production startup (January 2006). However, we have assumed the need to quickly scale up both collection and production over the start-up period. Over time, this allows the cost of goods sold to drop from an initial $114 \%$ of sales to $57 \%$. Net profit is projected to grow to $33 \%$ by 2009 . In the worst-case scenario, the cost of goods sold is obviously higher but drops at a similar rate. However, net profit by 2008 is projected at only $17 \%$ of sales.

We have assumed the availability of a credit from the United States Department of Agriculture for increased production. We used a rate of $\$ 0.25$ for each new gallon of production, which, based on current data, is conservative and is based on credits available in past years (as high as $\$ 1.50 / \mathrm{gal}$ ). The actual value of the credit may be greater or less than our estimates. Because the credit is only for increasing production, it has significantly less effect once the facility is operating at scale.

\subsection{Cash Flow}

Once the operation establishes itself and its markets, cash flow is quite healthy. By the beginning of 2006 (i.e., 5 months after start-up), monthly operating disbursements are about $71 \%$ of monthly receipts. Although some re-investment will undoubtedly be required for the planned expansion, cash flow will be able to make regular dividend payments starting in 2008. 


\section{Company Summary}

\subsection{Company History}

Co-op Power and the biodiesel production facility have been developed through the efforts of several cooperating entities: Co-opPlus of Western Massachusetts, Pioneer Valley Biodiesel Cooperative, Homestead Inc., Thomas Leue, and the Cooperative Development Institute.

Pioneer Valley Biodiesel Cooperative is an informal group of consumers who initiated the feasibility study for this business and who continue to organize bulk purchases of biodiesel, primarily to fuel their diesel vehicles. Representatives from the Pioneer Valley Biodiesel Cooperative are incorporating Co-op Power to serve as the majority owner of the biodiesel production facility.

Co-opPlus of Western Massachusetts is an energy cooperative owned by 1,400 households in Western Massachusetts dedicated to the development of renewable energy resources. Co-opPlus is providing technical assistance in the form of business planning and interim management and providing Co-op Power with its $\$ 750,000$ of initial equity.

These entities worked together with support from the Cooperative Development Institute, a non-profit economic development agency, to create Co-op Power and the biodiesel production facility. Professional biofuels and financial experts have also extensively reviewed the feasibility of the primary elements of this plan in an effort to include the best and most efficient technologies.

\subsection{Company Ownership}

Co-op Power Inc. is the majority owner of the biodiesel production facility. There will be other major equity participants that will have minority ownership interests.

Co-op Power is a new Massachusetts consumer-owned cooperative. It is headquartered at 277 Federal St., Greenfield, Massachusetts, and is dedicated to developing renewable energy resources for Western Massachusetts.

The equity classes of the limited liability company are:

- Class A

○ Co-op Power and its members $-\$ 750,000$ in cash equity

- $\$ 400,000$ in expenses paid during the first year, plus $\$ 100,000$ in member equity contributed over a 9-month period after completion of the business plan

○ \$250,000 United States Department of Agriculture grant for building improvements and equipment

- Class B

O Other investors $-\$ 1.75$ million in cash equity 
The structure of an additional \$2 million in equity required for the October 2006 expansion to $10 \mathrm{million} \mathrm{gal} / \mathrm{yr}$ has not yet been developed.

\subsection{Company Locations and Facilities}

The biodiesel production facility is currently co-located with Co-op Power and Co-opPlus of Western Massachusetts at 277 Federal St., Greenfield, Massachusetts, 01301. This business plan contemplates the purchase of a production facility and office space in the Western Massachusetts area.

\subsection{Management Structure}

During the organizational phase of the project, Lynn Benander and Larry Union, representatives of Co-opPlus, have filled the role of general manager on an interim basis. Thomas Leue has acted as the plant manager. The biodiesel production facility expects to hire the full-time general manager in February 2005 and the balance of the management team subsequent to that. The permanent operational management of the biodiesel production facility will consist of the president and chief executive officer (CEO) and the vice president of operations (see Attachment 5 for job descriptions). These two individuals will be responsible for the day-to-day operations of the company.

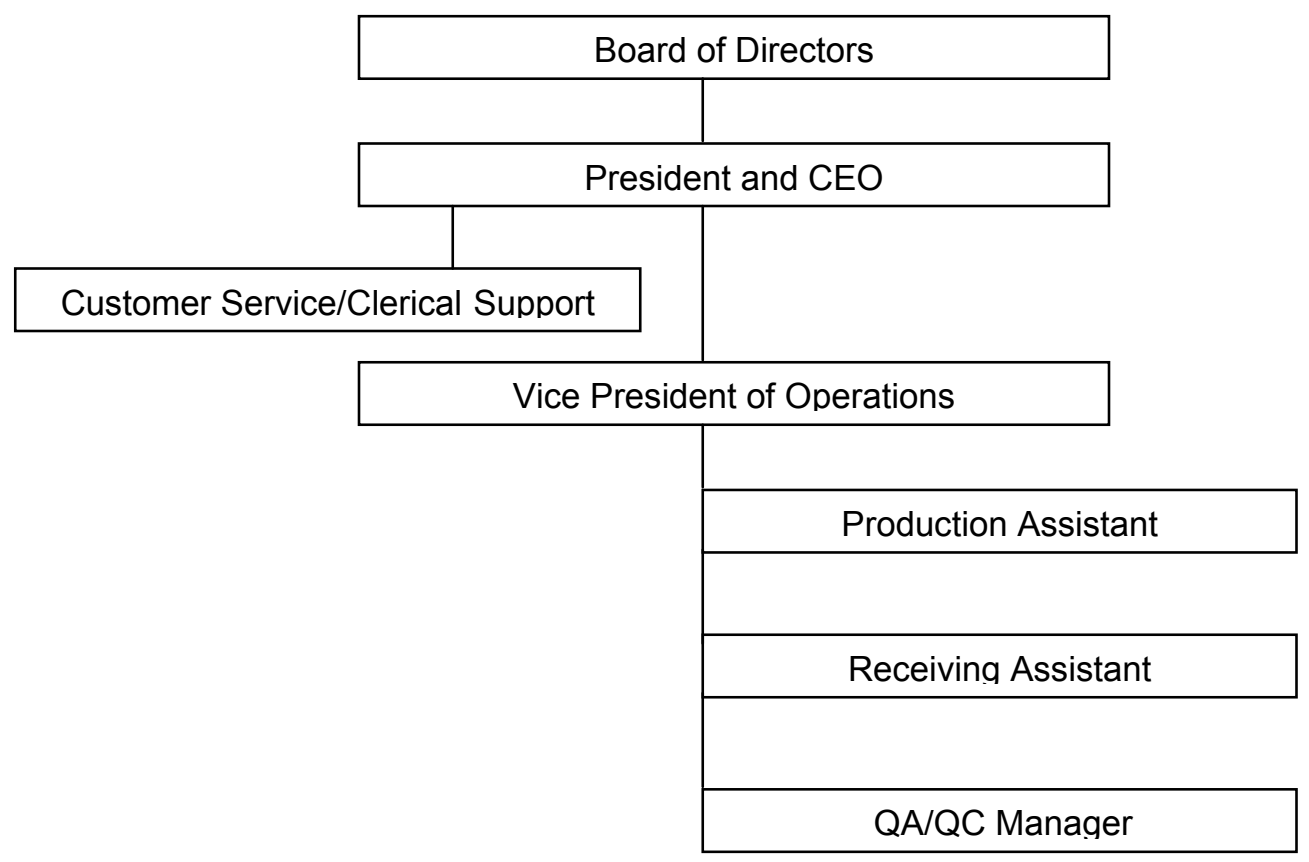

Figure 1. The biodiesel production facility organizational chart 


\section{$4 \quad$ Sourcing of Feedstock}

It takes four primary components to produce biodiesel fuel: RVO (yellow grease), methyl alcohol (methanol), caustic lye $(\mathrm{NaOH})$, and sulfuric acid $\left(\mathrm{H}_{2} \mathrm{SO}_{4}\right)$. The sources of these components (with alternatives for each) have been identified.

\subsection{Recycled Vegetable Oil}

Seven years have been invested in the identification of sources of RVO in the region. The cost of RVO is approximately $60 \%$ of total production cost and the largest cost component of the biodiesel production process. There is an abundance of this resource available at a reasonable cost by direct pickup by contracted individuals. We have identified more than 5,000 sources of RVO within a 60-mile radius of Greenfield, Massachusetts (see Attachment 4: Recycled Vegetable Oil Resources); of these, 399 restaurants are in the locally accessible four-county region. Based on door-to-door surveys of 97 local restaurants, we are confident that contracted supply is readily obtained. National studies have demonstrated about 1.1 gal of collectable RVO are generated in restaurants per person in the local population per year. Our project needs are $1.8 \mathrm{million} \mathrm{gal} / \mathrm{yr}$. As stated earlier, if only about one-third of the regional RVO resource is collected for biorefinery operation, it will require a population of just fewer than 5 million people to produce sufficient feedstock. That population is easily found in the Northeast (see Attachment 3: Population: New England, New York, New Jersey, Pennsylvania).

Our RVO supply will be collected by "grease farmers," who are either independent contractors or farmers back-hauling barrels of grease from Boston and New York City. They will be equipped with a standard pickup truck, a flat-bed pickup truck, or a livestock or vegetable delivery truck. They will deliver the oil to our receiving station for a fixed price per

gallon. An initial poll of possible vendors for this service showed a high level of interest and a likelihood of this market being successful.

The grease farmers will make agreements with restaurants, schools, and other sources of RVO for collection service. The grease farmers will set their own price structure. Generally, the cost of a drum of oil picked up is planned to be around $\$ 20$. This is very competitive with other service vendors in our region; they currently average around $\$ 38 /$ drum picked up. The independent contractors may adjust their pricing upward when they obtain a sufficient customer base. They will truck a minimum, if using a pickup truck, of six filled drums per trip to the refinery for our use and more - approximately 20 filled drums - if they use a flatbed or livestock delivery truck. The grease farmers will obtain revenue from the waste generators and a fluctuating unit fee from the refinery for delivered oil. The initial fee paid will be $\$ 0.30 /$ gal for delivered oil, based on contaminate-free oil. Fees will be paid monthly via check. The grease farmers will pick up the cleaned, empty drums from the biodiesel production facility. The drums will remain the property of the refinery. 
The independent contractors will face competition from existing rendering companies and local grease collection services. This will likely put downward pressure on the price of $\$ 20 /$ drum picked up. We believe this will influence restaurants to switch to these independent contractors. We believe there is a significant number of restaurants that do not have a pickup service or that are illegally dumping RVO (based on our survey of restaurants within 60 miles of Greenfield). These establishments will be attracted to the initial lower pickup cost and provide sufficient opportunity for the independent contractors to secure accounts in the face of competition from existing service providers.

We have identified several individuals who are interested in providing this service. Although none of the identified program participants currently has contracts with restaurants for RVO pickup, our restaurant surveys indicated substantial demand for a more cost-effective RVO pickup service. We are working with the Cooperative Development Institute to develop the farmer back-haul strategy. The Cooperative Development Institute plans to use its extensive network of relationships with local farmers, in addition to an already established back-haul operation (fish farm deliveries to Boston), to develop this strategy. Finally, we are working with Mass Energy, located in the Boston area. It has agreed to assist the City of Boston in setting up an RVO collection service.

In the first 3 years of development, any shortfall in RVO supplies will be made up on the open market by purchasing this commodity from existing regional rendering companies that have agreed to sell the materials to the biorefinery or from existing waste collection companies such as SalCorp, which currently picks up more than 75,000 gal of RVO a week from restaurants and sells "untreated" RVO. This is the more expensive source of RVO, but our cash flow analysis continues to show positive values under even the worst-case scenario of purchasing mostly from these sources.

The regional rendering companies are:

- Western Mass Rendering - Southwick, Massachusetts

○ 25 miles from Greenfield

- Approximately $\$ 0.03 /$ gal transportation cost

- Baker Commodities - North Billerica, Massachusetts, and Albany, New York

- 100 miles from Greenfield

○ Approximately $\$ 0.07 /$ gal transportation cost

- Darling International - Newark, New Jersey

- 150 miles from Greenfield

- Approximately $\$ 0.10 /$ gal transportation cost

- Corenco - Tewksbury, Massachusetts

- 100 miles from Greenfield

○ Approximately $\$ 0.07 /$ gal transportation cost. 
The waste collection companies are:

- SalCorp - Queens, New York

- RVO from restaurants in New York City

- Preferred source

- Currently negotiating supply contract for all bulk requirements through 2007

- 130 miles from Greenfield

- Approximately $\$ 0.07 /$ gal transportation cost

- Corcom Commodities - Elora, Ontario

- RVO from Canada

- Embargo on shipments of RVO from Canada expected to be lifted in March2005

○ Proposed 3-year supply contract currently under investigation

- American Byproducts - Boston, Massachusetts

- Collects fryolator grease in the greater Boston area.

Table 3. Feedstocks Purchased From Collecting Companies or Rendering Companies

\begin{tabular}{lllll}
\hline 2005 & 2006 & 2007 & 2008 & 2009 \\
\cline { 2 - 5 } & & & & \\
$64 \%$ & $81 \%$ & $87 \%$ & $78 \%$ & $73 \%$
\end{tabular}

We will be using a standard open-topped, 55-gal drum-based collection system. This allows us to obtain inexpensive, standardized containers that can be handled by one person, cleaned thoroughly, and distributed easily. In addition, this is a commonly used system in the industry. Our drums will be labeled to distinguish our service from other services.

The service provider, the customer volume, the regional price structure, and the type of service provided set pricing of the collection service. By using three drums per customer, our service agreement will maintain sufficient capacity for the RVO generator. This yields approximately 100 gal of vegetable oil per site visit. Education and the pricing structure provided by the independent contractors will encourage customers to avoid significant quantities of water in the drums, although some water is inevitable. All significant contaminants will be removed in the factory-based oil receiving system.

\subsection{Methyl Alcohol}

Anhydrous methanol is available from several regional chemical supply houses. Methanol is bulk shipped to Selkirk, New York, and New Haven, Connecticut. This offers the opportunity for competitive pricing. The price of methanol closely follows natural gas pricing and represents about $12 \%$ of our product cost. Full excess methanol recovery systems will minimize the cost and use of this chemical. 
Methanol is priced according to the volume of deliveries. The best prices are obtained with full-truckload deliveries of 7,000 gal. Our receiving tank will have 10,000 gal of capacity. Designed according to the National Fire Protection Association fire code, this system will be located in a protected area with a berm, nitrogen gas blanket, and fire control systems. Since January 2002 , methanol prices have risen from $\$ 0.375 /$ gal to $\$ 0.95 / \mathrm{gal}^{3}$ at the Houston, Texas, rack. The price of methanol is expected to remain high for the foreseeable future. Our price delivered from Selkirk, New York, or New Haven, Connecticut, will include an additional \$0.07-\$0.10/gal transportation cost.

\subsection{Caustic Lye}

Caustic lye $(\mathrm{NaOH})$ is used as a catalyst and is less than $1 \%$ of the product cost. It, too, is available from several regional vendors in bulk.

We will evaluate the use of pre-mixed sodium methoxide because it is easier to handle a liquid than a hand-carried solid. In addition, the liquid has been shown to be up to four times as effective of a catalyst as the solid, site-mixed chemical.

\subsection{Sulfuric Acid}

Sulfuric Acid $\left(\mathrm{H}_{2} \mathrm{SO}_{4}\right)$ is used as a neutralizer and is also less than $1 \%$ of the product cost. It is available from several regional vendors in bulk.

\footnotetext{
${ }^{3}$ Methanex Regional Posted Contract Prices: Valid through Dec. 31, 2004.
} 


\section{Competitive Comparison}

Biodiesel is the rising star of the alternative transportation fuel industry. Because of its recycled base materials, clean air performance, impressive net energy balance, and aesthetic cache, demand is rising in the Northeast faster than it can be supplied. As of this writing, large areas of Vermont, Connecticut, and Western Massachusetts have no local sources of supply. For these and other reasons, biodiesel is about $10 \%$ more expensive in the Northeast than in other parts of the United States.

By every measure, the biodiesel production facility will have a highly competitive product. The pricing projected to meet our goals is less than any other regional source, and potential customers have termed it extremely competitive. The recycled base material will appeal to energy- and resource conservation-aware customers, especially when it is compared with Midwestern sources that use a virgin soy oil base. One of our challenges will be to dispel any negative connotations that an RVO-based biodiesel may have relative to being used in a Northern climate. Our strategy to focus on $2 \%-5 \%$ blends will help minimize any potential negativity directed at an RVO-based product.

As the first commercial biodiesel production facility in the Northeast, we expect to obtain contracts for bulk sales in advance of project initiation up to $95 \%$ of our anticipated production. The balance of production will be reserved for initial retail sales developments, a portion that is expected to grow yearly.

Current regional sources of biodiesel are located hundreds of miles west or south of our proposed location (e.g., in Cincinnati, Ohio; at Griffin Industries in Kentucky; and at the World Energy site in Lakeland, Florida). Future competitive production systems have been announced for suburban Montreal, Ontario. Canadian systems have not announced plans to export biodiesel to the United States. Others new production centers are in early development stages. These include facilities near New York City and Philadelphia and in West Virginia, North Carolina, Georgia, and Delaware. However, announced systems may precede actual production systems by years or longer. We will likely have a slight cost advantage for only 1 or 2 years. It is imperative that we work to reduce our cost and increase our efficiency. Our plan to increase capacity to $10 \mathrm{million} \mathrm{gal} / \mathrm{yr}$ by October 2006 is a direct response to the perceived competitive landscape.

Although the Department of Energy projects U.S. biodiesel production to grow by nearly $40 \%$ this year, the biodiesel production facility will be the only operational production system within more than 500 miles of our location at the time of our projected opening. Our early entry into the market will help us develop distribution networks and build customer loyalty. Because our pricing structure is planned to be less than the current regional average price for biodiesel, we expect to rapidly gain market share. 


\section{$6 \quad$ Sales and Marketing Strategy}

\subsection{Sales/Distribution Strategy}

\subsubsection{Wholesale Sales}

Initial sales will focus on biodiesel as an additive for home heating oil (HHO) dealers throughout the Northeast. The biodiesel production facility also anticipates providing bulk biodiesel to regional diesel fuel distributors for mixing blended fuel in various ratios. Written agreements for these business relationships are currently in development. These agreements will detail the volume, price, delivery conditions, and biodiesel-to-diesel fuel ratios of the products developed. These agreements will also include branding rights and responsibilities so the ultimate users will be assured of biodiesel quality.

Sales of biodiesel as a blending agent with standard or low-sulfur HHO to produce a green alternative will be initiated for late fall of 2005 deliveries. This use of biodiesel will help sell the first year's production before all of the required registrations for road fuel are in place. This will be the preferred market focus for the first 3-5 years. Introductions of this product in Maine, near Boston, and in Holyoke have been sustainable, and these programs are expanding next year. For example, Alliance Energy of Holyoke, Massachusetts, has announced it will add 3\% biodiesel to all fuel it sells in 2004.

The HHO market presents many challenges, not the least being its inherent seasonality. To minimize the business effect of seasonality, as government mandates and incentives come into play for diesel fuel and we meet the appropriate standards of the major oil companies and insurance providers, we expect that our sales focus will shift more to the lubricity additive and blended fuel markets for diesel fuel.

The sales effort for our wholesale product will be carried out primarily by the general manager of the biodiesel production facility. A direct sales strategy will be targeted at the operational heads of the heating oil dealers and regional diesel fuel distributors.

\subsubsection{Retail Sales}

Our program also includes a retail component early in our development plans. This will take the form of packaged "private label" biodiesel.

Packaged "red-dyed" biodiesel will be sold as private-labeled B-20 in 5- and 55-gal packages. Two package plans will be initiated.

- Fifty-five-gal drums of biodiesel will be sold for use on farms, construction sites, and residences. With these drums will be user information about use and safe handling. The drums will be deposit-valued and refillable. 
- Five-gal fuel containers manufactured for diesel storage are a convenient and attractive means of selling fuel for off-site use. These packages may be refilled after purchase. Similar to the "coffee club" programs operated by convenience stores, customers may pay a premium for the initial filled container and then receive a modest discount on subsequent refillings. Refilling can take place at participating retailers such as auto parts stores, garages, and food cooperatives. An attractive label with handling information would promote brand loyalty. This also offers a distinct advantage for users who mix a percentage of biodiesel with standard fuel in their tanks by leading to improved costs performance and reducing winter cold weather operation problems.

\subsubsection{Distribution}

\subsubsection{Bulk}

Biodiesel may be handled with any equipment suitable for handling petroleum fuel. Biodiesel may be sold "free on board" (FOB) in the purchaser's trucks or delivered by a contracted carrier at $\$ 0.03 /$ gal for local deliveries and as much as $\$ 0.10 /$ gal for deliveries to the outer edges of our Northeastern service territory. Biodiesel-blended fuel, such as B-02 or B-20, is normally prepared by loading B-100 into a carrier vehicle already pre-loaded with the petroleum base fuel. The base plan is to have local customer's fuel trucks pre-loaded with $\mathrm{HHO}$ or diesel fuel arrive at our site and be topped off with the appropriate volume of B-100 to achieve the desired biodiesel ratio. For more remote customers, we will negotiate with the Springfield-, Boston-, Albany-, New Haven-, New York City-, and New Jersey-based "racks" to have B-100 distributed to customers there. The product will need to be stored on site in heated and insulated storage tanks to avoid clouding that may occur in cold weather.

\subsubsection{Private Label Packaged Product}

All packaged biodiesel will be dyed "red" to avoid Internal Revenue Service issues regarding off-road and heating oil use. Several additional vendor locations are willing to sell a privatelabeled product. The following locations have expressed interest in retailing packaged biodiesel at some time in the future. These locations are given as examples of the types of retail operations that would be appropriate.

- Foskett Equipment

Rt. 171-S, Woodstock, CT 06281

Contact: Harold Foskett

Type of sales: Agricultural Equipment

- John Deere

P.O. Box 432, Sanford, ME 04073

Contact: Tom Swan

Type of sales: Agricultural Equipment

- General Truck

I-91, Exit 5, Westminster St., VT

Contact: Bodie

Type of sales: Construction Equipment 
It is anticipated that many more such retail vendors will be identified as soon as we have product available. The plan for distribution will be to service established private-label accounts with the outward-bound travel of the grease collectors. This will minimize costs and allow us to directly collect feedback. Examples of other retailers we expect to approach are West Marine and other retail marine outlets; big box hardware retailers and automotive chains such as PEP Boys, Autozone, Home Depot, Aubuchon, ACE Hardware, and Sears/Kmart.

Fifty-five-gal packages are standard drums available for a low cost from drum recyclers locally. There would be a deposit on each drum of fuel sold and a cleaning charge for the returned drums.

Five-gal packages consist of U.S. Department of Transportation- and state fire marshalapproved yellow plastic diesel fuel containers. These are available for approximately $\$ 5$ each from the Internet. These containers have the advantage of being safe and convenient for customers to dispense as they see fit, which helps them achieve the desired B-XX dilution at the lowest cost and greatest convenience. When empty, the customer can return the container to the store for a deposit return and pick up a filled container. These containers would include a laminated attached label that includes required Department of Commerce information, brand information, and user guidance.

\subsection{Markets and Marketing Strategy}

The biodiesel production facility will focus its sales and marketing efforts in the wholesale markets as it seeks to establish its presence in the New England marketplace. Simultaneously, a smaller retail effort will be initiated at the biorefinery to serve the local transportation market and visitors. This balance between retail and wholesale will be adjusted as the retail market grows. Initial expectations are for $95 \%$ of the product to be sold wholesale and $5 \%$ of the product to be sold retail at full operating capacity.

We have budgeted $\$ 60,000 / y r$ for marketing expenses. For fiscal year 2005 , we anticipate spending those dollars as follows:

Collateral - Wholesale (brochure designed to hand out or mail) Retail (basic hand-outs)

Postage

Travel - General manager making sales calls throughout Northeast
$\$ 15,000$

$\$ 3,000$

$\$ 2,000$

$\$ 20,000$

Advertising - Trade magazines (heating oil, diesel equipment, restaurants) $\$ 20,000$

Total \$60,000

Although marketing cost might be expected to decline over time as repeat customers are established, it is our expectation that our annual marketing cost will remain at this level because of competition from new market entrants. We also expect to shift our marketing focus to different segments from time to time as part of our market growth strategy. 
We plan to initially provide two basic wholesale products and a basic retail product.

- Wholesale products (95\% of steady-state capacity)

○ Bulk B-100 FOB for HHO distributors $-80 \%$

○ Bulk B-100 FOB for diesel fuel distributors and fleets $-20 \%$

- As a lubricity additive

- For blending up to B-20

- Retail products ( $5 \%$ of steady-state capacity)

○ B-20 (5- or 55-gal containers)

\subsubsection{Home Heating Oil (80\% of Wholesale Sales)}

The HHO market in the Northeast (New England, New York, New Jersey, and Pennsylvania) is very competitive, with more than 500 independent dealers in Massachusetts alone. In 2002, HHO sales in the Northeast were 5.2 billion gal. ${ }^{4}$ Biodiesel offers these dealers the ability to differentiate their product from their competition's by its renewable content, its reduced dependence on foreign oil, or both. HHO in a $2 \%-5 \%$ dilution of biodiesel provides an alternative fuel that does not require any special handling, equipment upgrades, or weather-related adjustments with only a slight increase in price (estimated at $\$ 0.05-\$ 0.10 /$ gal more by local heating oil dealers). Thus, biodiesel is an ideal product for this very large and diverse market in the Northeast. Our plan is to initially focus most of our marketing and sales efforts on this segment. We believe that this market segment offers the best likelihood of initial success.

Our first approach to estimating the biodiesel HHO market was to interview local HHO dealers. These conversations indicate that if $10 \%$ of customers in just two local counties were to switch to biodiesel, it would create a sufficient market to consume $8 \%$ of our planned wholesale sales.

Table 4. Home Heating Oil Market in Gallons/Year (as Estimated by Local HHO Dealers)

\begin{tabular}{|c|c|c|c|c|}
\hline HHO Market & $\begin{array}{c}\text { Approximate Annual } \\
\text { Conventional Fuel } \\
\text { Usage }\end{array}$ & $\begin{array}{c}\text { Percentage That } \\
\text { Might Switch to } \\
\text { Biodiesel }\end{array}$ & $\begin{array}{c}\text { Gallons/Year } \\
\text { of B-3 }\end{array}$ & $\begin{array}{c}\text { Translated into } \\
\text { Gallons/Year } \\
\text { of B-100 }\end{array}$ \\
\hline $\begin{array}{l}\mathrm{HHO} \text { in Franklin } \\
\text { and Hampshire* }\end{array}$ & 45 million gal & $10 \%$ & 4.5 million & 135,000 \\
\hline
\end{tabular}

Data from local HHO dealers

An alternate way to estimate the market is to analyze total HHO usage in the Northeast and Massachusetts. For example, data from the Energy Information Administration for 2002 indicate that Massachusetts homes used 892,689,000 gal of No. 2 heating oil. Western Massachusetts (which includes Berkshire and Hampden counties in addition to Franklin and Hampshire counties) is $12.5 \%$ of the population of Massachusetts. Therefore, Western Massachusetts uses about 111,586,125 gal of No. 2 heating oil a year.

\footnotetext{
${ }^{4}$ Energy Information Administration. Fuel Oil and Kerosene Sales 2002.
} 
It is clear that the HHO markets in Western Massachusetts alone will not support our sales plans. Assuming that we convert $48 \%$ of the market is highly unlikely and unrealistic. It is clear that the HHO market in the entire state of Massachusetts and the Northeast as a whole is more than sufficiently large enough to support our plans without yielding to unrealistic market penetration assumptions. Table 5 shows market penetration levels for $100 \%$ of our wholesale plan. We actually are only targeting $80 \%$ of the wholesale plan for the HHO market.

Table 5. Home Heating Oil Usage in Gallons per Year (based on EIA data)

\begin{tabular}{llll}
\hline \multicolumn{1}{c}{ HHO Market } & Total Usage & $\begin{array}{c}\text { Gallons/Year B-100 } \\
\text { at 3\% Blend }\end{array}$ & $\begin{array}{c}\text { Market Penetration Required } \\
\text { for 100\% Wholesale Plan } \\
\mathbf{2} \text { Million Gal/Yearl } \\
\mathbf{1 0} \text { Million Gal/Year }\end{array}$ \\
\cline { 2 - 4 } & $5,200,000,000^{1}$ & $156,000,000$ & $1.035 \% / 5.4 \%$ \\
Northeast & $892,689,000^{1}$ & $26,780,670$ & $6.03 \% / 32 \%$ \\
Massachusetts & & & \\
$\begin{array}{l}\text { Western Massachusetts } \\
\text { (12.5\% of the population of } \\
\text { Massachusetts) }\end{array}$ & $111,586,125$ & $3,347,583$ & \\
\hline
\end{tabular}

\subsubsection{On-Road Diesel Fuel (20\% of Wholesale Sales)}

The biodiesel production facility's on-road diesel fuel market is composed of three segments:

1. Lubricity additives

2. On-road B-20

3. Fleets.

The combination of these three market segments seems to substantiate our assumption of being able to sell $20 \%$ of our wholesale plan here.

The market growth for B-02 nationally is primarily due to pending regulations (effective June 2006) for lower sulfur-content diesel fuel that will require lubricity additives. Because B-02 is less subject to cold weather or price concerns, the biodiesel production facility expects that this will become a primary market in future years. 
The market potential for lubricity additive given the total amount of diesel fuel sold in Massachusetts alone is 7,964,340 gal/yr (at a 2\% mixture). Several chemical additives can deliver the required lubricity performance. Using biodiesel, however, provides the advantages of renewable resources and local availability. This makes it a viable overall solution as an additive. Although B-100 may be slightly more expensive than the other proposed additives (before any tax incentives), because of the relatively low mixture percentages, price differential on a per-gallon basis is minimal.

The $20 \%$ initial wholesale production target will provide the lubricity additive for the following annual retail sales of diesel fuel:

- $0.39 \%$ of Northeast retail sales

- $4.2 \%$ of Massachusetts retail sales

- $33.7 \%$ of Western Massachusetts retail sales.

Given the above required market penetration level, we expect that contracts with two or three local fuel distributors in each of the Northeastern states for $10,000-15,000 \mathrm{gal} / \mathrm{yr}$ or more is a reasonable and attainable initial target.

Table 6. No.2 Transportation Fuel in Gallons/Year

\begin{tabular}{|c|c|c|c|}
\hline & Total Usage & $\begin{array}{l}\text { Gallons/Year B- } \\
100 \text { at } 2 \% \text { Blend }\end{array}$ & $\begin{array}{c}\text { Market Penetration } \\
\text { Required for } 100 \% \text { of } \\
\text { Wholesale Plan } \\
2 \text { Million Gallons/Year/ } \\
10 \text { Million Gallons/Year }\end{array}$ \\
\hline $\begin{array}{l}\text { Northeast } \\
\text { Massachusetts } \\
\text { Western Massachusetts } \\
\text { (12.5\% of the population of } \\
\text { Massachusetts) }\end{array}$ & $\begin{array}{r}4,271,735,000^{1} \\
398,217,000^{1} \\
49,777,125\end{array}$ & $\begin{array}{r}85,434,700 \\
7,964,340 \\
995,542\end{array}$ & $\begin{array}{l}1.9 \% / 10 \% \\
21 \% />100 \% \\
>100 \%\end{array}$ \\
\hline
\end{tabular}

Data from the Energy Information Administration for 2002

The overall market for B-20 is growing but is still relatively small in the Northeast. It will take considerable time and effort to develop this market; however, we believe our beginning assumption of $20 \%(335,920 \mathrm{gal} / \mathrm{yr})$ of our wholesale sales targeted at diesel fuel distributors and fleets is reasonable given the interest that we have already seen from the New England market.

Biodiesel helps clean up emissions for a biodiesel-diesel fuel mixture in larger amounts than its proportion in any mix. Because the Northeast has recently been termed a non-compliance area for air quality, we expect biodiesel to gain widespread acceptance for fleets that must reduce pollution levels. Biodiesel fulfills the mandates of the Energy Policy Act (EPAct), the federal requirement for energy alternatives for federal, state, and some utility fleets. We are cataloging the mandated fleets and plan to partner with diesel fuel distributors to bid for contracts for B-20 fuel. 
B-20 has been shown to be the lowest-cost method of EPAct compliance for diesel fleet users. Our research shows there are 29 EPAct communities in Western Massachusetts mandated to use alternative fuels for their fleets. We plan to initially focus on Western Massachusetts municipal fleets; federal fleets, including the post office; and electric, cable, and water utility fleets. These will likely yield better sales because of familiarity and will help build the local reputation of the biodiesel production facility in the rest of the region.

Table 7. Potential Fleet Fuel Market Based on Existing Usage

\begin{tabular}{|c|c|c|c|c|}
\hline $\begin{array}{l}\text { Vehicle Fuel } \\
\text { Market }\end{array}$ & $\begin{array}{l}\text { Current B-20 or } \\
\text { Diesel Use } \\
\text { (Gallons/Year) }\end{array}$ & $\begin{array}{c}\text { Add Other } \\
\text { Similar Markets }\end{array}$ & $\begin{array}{c}\text { Potential } \\
\text { Gallons/Year } \\
\text { of B-20 }\end{array}$ & $\begin{array}{c}\text { Potential } \\
\text { Gallons/Year } \\
\text { of B-100 }\end{array}$ \\
\hline $\begin{array}{l}\text { Municipalities } \\
\text { such as Keene, } \\
\text { New Hampshire }\end{array}$ & 50,000 & & & \\
\hline $\begin{array}{l}\text { Municipalities } \\
\text { such as } \\
\text { Amherst, } \\
\text { Massachusetts }\end{array}$ & 5,000 & $\begin{array}{l}\text { Northampton, } \\
\text { Greenfield, } \\
\text { Springfield, } \\
\text { Holyoke, } \\
\text { Massachusetts }\end{array}$ & $\begin{array}{l}\text { Assume all at } \\
\text { modest amount } \\
\text { of } 5,000 \mathrm{gal} / \mathrm{yr}= \\
25,000 \mathrm{gal} / \mathrm{yr}\end{array}$ & 5,000 \\
\hline $\begin{array}{l}\text { Colleges such } \\
\text { as University of } \\
\text { Massachusetts, } \\
\text { Amherst, Keene } \\
\text { State }\end{array}$ & $4,000-7,000$ & $\begin{array}{l}\text { Smith, Mount } \\
\text { Holyoke, } \\
\text { Amherst, } \\
\text { community } \\
\text { colleges }\end{array}$ & $\begin{array}{l}\text { Assume all at } \\
3,000 \mathrm{gal} / \mathrm{yr} \text { each } \\
=18,000\end{array}$ & 3,600 \\
\hline Off-road uses & $291,640,000$ & Assume 1\% & $2,916,400$ & 58,328 \\
\hline Total: & & & & 66,928 \\
\hline
\end{tabular}

The City of Keene and Keene State College switched all their diesel vehicles to B-20, but they were subsidized by the state of New Hampshire for the additional cost of biodiesel over petroleum diesel for the first 2 years. This state support has since dried up, but they have kept biodiesel usage at the same levels, although with difficulty. Given current state and local fiscal constraints, usage more similar to that of Amherst, Massachusetts, is used for future projections. Municipal use of B-20 - based on the Amherst, Massachusetts, experience - is approximately $0.1 \mathrm{gal} / \mathrm{person}$. This demonstrates potential sales of 80,000 gal of B-20, or 16,000 gal of B-100, per year to Western Massachusetts cities and towns.

Our B-100 will be marketed at competitive rates to the regional biodiesel distributors that purchase from Midwestern sources. Contract purchasers - such as higher education, municipal, and certain corporate customers - may choose our product based on lower costs, regional production values, and superior performance. We will sell bulk biodiesel via contracted carriers in 3,000- and 7,500-gal lots throughout the Northeast. 


\subsection{Wholesale B-100 Product Pricing}

According to the Alternative Fuel Index (www.altfuelsindex.com) published by the New York-based Energy Management Institute (www.energyinstitution.org), prices for B-100 have ranged from a low of $\$ 2.074$ on Oct. 16,2003 , to a high of $\$ 2.540$ on Dec. 16, 2004, during the past 14 months. Diesel prices have ranged from a low of $\$ 0.910$ on Dec. 3, 2003, to a high of $\$ 1.646$ on Oct. 21,2004 , in that same time period.

Generally, across this nation, B-100 biodiesel is priced at a minimum of $\$ 1 /$ gal more than the price of wholesale petroleum diesel fuel, and the price fluctuates with that commodity.

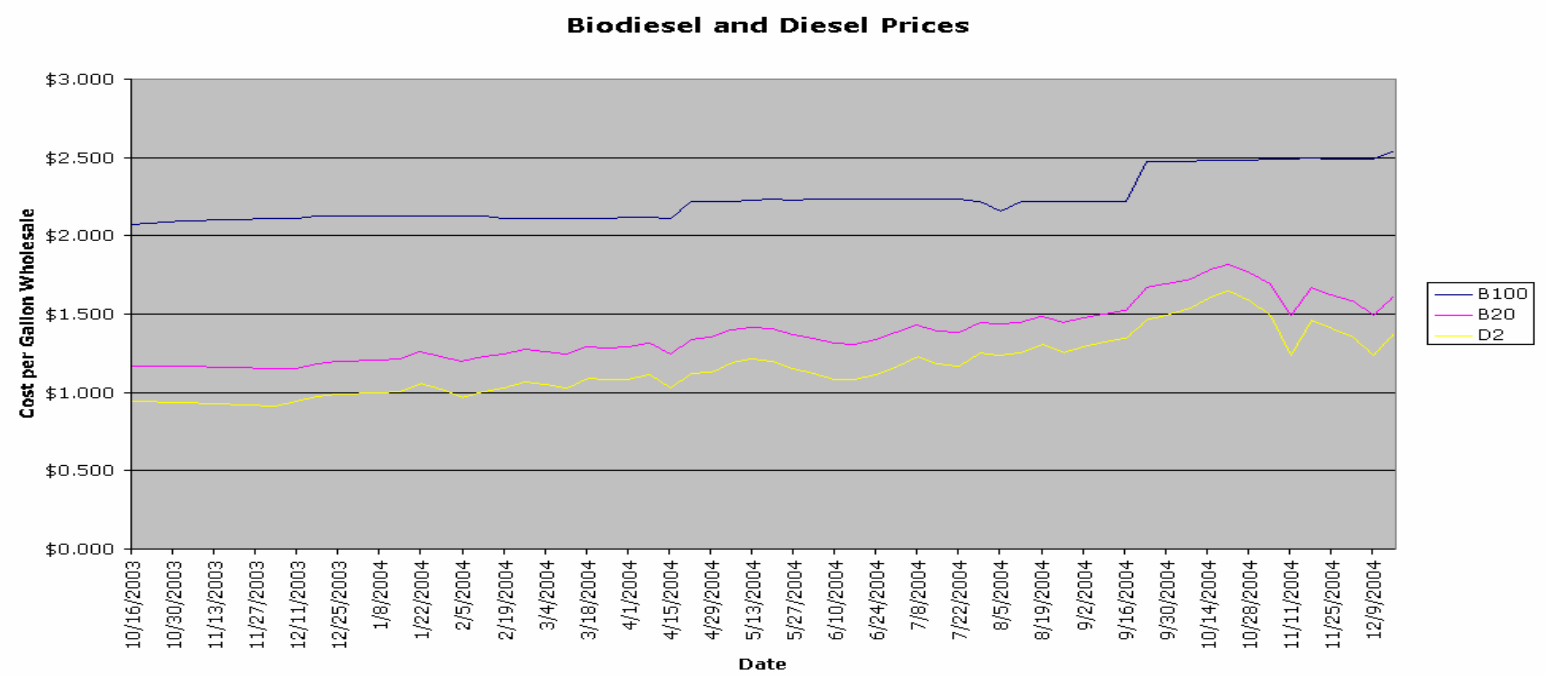

Figure 2. Biodiesel and diesel prices

The biodiesel production facility's wholesale price of B-100 biodiesel is currently calculated at the lower of $\$ 2.10$ or a $\$ 0.65 /$ gal mark-up on our total cost (fixed and variable). This pricing methodology results in our price being a "minimum" of $\sim \$ 0.18$ /gal less than current distributor prices in the Northeast (estimated at $\$ 2.28 /$ gal or more) and as much as $\$ 0.44 / \mathrm{gal}$ less if current market prices are carried out to 2009. Given current market pricing norms for B100 , our base-case plan yields significant price competitiveness for the biodiesel production facility. Our base-case plan is to use this advantage to assist in meeting our market penetration goals. Obviously, we will weigh the benefits of increased market penetration against higher margins as we gain initial insight into our ability to sell our product.

Table 8. Projected Average Wholesale Price/Gallon

\begin{tabular}{llllll}
\hline & $\mathbf{2 0 0 5}$ & $\mathbf{2 0 0 6}$ & $\mathbf{2 0 0 7}$ & $\mathbf{2 0 0 8}$ & $\mathbf{2 0 0 9}$ \\
\cline { 2 - 6 } Average wholesale price/gal & $\$ 2.10$ & $\$ 2.041$ & $\$ 1.962$ & $\$ 1.945$ & $\$ 1.924$ \\
\hline
\end{tabular}




\subsection{Retail Pricing}

Packaged pricing is based on the wholesale price plus a retail mark-up. Package product will be sold at retail and original equipment manufacturer partner sites. We will develop a strategy for retail sales of package product at partner sites based on additional research and market testing as part of our retail pilot.

Table 9. Projected Average Retail Price/Gallon On-Road

\begin{tabular}{lcccccc}
\hline & & 2005 & 2006 & 2007 & 2008 & 2009 \\
\cline { 2 - 7 } Average retail price/gal on-road & $\$$ & 2.804 & $\$ 2.745$ & $\$ 2.666$ & $\$ 2.649$ & $\$ 2.628$ \\
\hline
\end{tabular}

\subsection{Future Products}

Biodiesel, as produced by this facility, is useful in a variety of ways. Without changing the basic product, except for the addition of possible perfumes or dyes, biodiesel may be used as a very effective and cost-competitive degreasing compound for garage-type parts washers. Priced at a premium above road fuel, this degreaser would be available at approximately onehalf of the current degreasing compound prices. In addition, unlike the standard compounds, this degreaser would provide superior performance and be easy on hands, non-toxic, and disposable in recycled oil burners. Test marketing of Yellow Brand Biodiesel gained acceptance as a preferred alternative to the standard degreaser. Marketing plans include the expansion of piloted programs. For example, one garage may be selected to put on a demonstration in which regional garage owners are invited to bring a random engine part for a free cleaning. Where this has been tried, the only cost to the biorefinery is the use of approximately 10 gal of biodiesel and a few dollars for refreshments.

Other applications of biodiesel for niche users include:

- Adhesive remover

- Aircraft fuel

- Asphalt cleanup agent

- Crop adjuvant

- Graffiti remover

- Hand cleaner

- Metal working lubricant

- Mold release agent

- Oil spill clean-up and bioremediation agent

- Corrosion preventative

- Paint and resin cleanup

- Parts cleaner and degreaser

- Screen printing ink remover.

To explore these options, test marketing will be conducted in appropriate markets. This will be facilitated by donations of small packages of biodiesel to key users for testing and feedback. 


\section{$7 \quad$ Site Requirements}

The ultimate biorefinery site must meet our basic requirements for a production facility. These include:

- A minimum of $10,000 \mathrm{ft}^{2}$ of production space and $1.000 \mathrm{ft}^{2}$ of office space

- A production space expandable to $20,000 \mathrm{ft}^{2}$

- A location in the four-county area of Western Massachusetts (Franklin, Hampshire, Berkshire, or Hamden counties)

- Two loading docks

- Easy access for tractor trailers and oil trucks

- City water (a minimum 12-inch water main) and sewage

- 480-volt three-phase power

- Industrial zoning

- A satisfactory 21-E environmental assessment.

Other site considerations include:

- Rail spur availability

- Existing boilers

- Qualified for state and local economic development assistance

- Existing storage tanks (adaptable for oil and grease). 


\section{Technology}

\subsection{Technology Choices}

Fourteen vendors of biodiesel processing technology have been identified and compared. Seven of these are continuous processors that have some drawbacks for our operation and skill set. Our plan calls for an initial production capacity of approximately 2 million gal $/ \mathrm{yr}$ and growing to $10 \mathrm{million}$ gal/yr. This initial-size facility was chosen to match our perceived ability to obtain the RVO and deliver the profitability required. The continuous-process technologies were eliminated from consideration because a 1-2-shift, 5-days-per-week operation is a better fit for how we feel we can operate the facility in our community. As the need for increased production capacity or space limitations arise, we may need to take another look at continuous-processing technology.

Of the seven batch or plug-flow processors, single-stage processors do not appear to be appropriate for our demanding RVO and processing requirements. Also, several of the larger system vendors are not fabricating processors sized for our goals of less than 5 million gal of product per year. This reduces the known options to a few potential technologies.

From a cost standpoint, the prices quoted by vendors do not include funds for a collection system, oil pretreatment and storage, product storage and dispensing, office systems, spare parts, training, advertising, or contingencies. Our capital and start-up budget is an estimate based on discussions, interviews, and budgetary quotes with vendors. We believe that our cost estimates, including contingencies, are sufficient to complete the project.

We thus identified four technology vendors as providers of similar batch processing equipment for comparisons. These were:

- Biodiesel Industries of Santa Barbara, California

- Biodiesel International of Austria

- Imperial Western Products Inc. of Coachella, California

- Fitzsimmons Systems Co. (a new technology source under evaluation).

All of the comparison technologies described meet ASTM standards, currently have facilities in operation, and come with some level of manufacturer warranty. In addition, our evaluation team visited facilities that use the technologies of these vendors.

Biodiesel Industries' technology is a modular batch process, with each module of production fitting into a standard $40 \mathrm{ft} \times 8 \mathrm{ft}$ footprint. Biodiesel Industries has four commercial production facilities in operation. These are located in Rutherford, Australia (10 million gal/yr); Las Vegas, Nevada (3 million gal/yr); Longmont, Colorado (3 million gal/yr); and Port Hueneme, California (150,000-gal/yr operation run by the Navy). This technology is designed to operate using a variety of feedstocks. All of the currently operating facilities are producing to ASTM standards except the one in Longmont, Colorado, which is still in start-up mode. There is a 3 -month lead time for this equipment. 
Biodiesel International's processing systems are built in Germany and shipped in roll-off containers. Tankage is usually purchased and installed locally. They offer a batch-type system for processors up to 5 million gal/yr and batch-continuous systems in sizes larger than that. Delivery time is estimated at about 9 months. The system has an acid-base type of conversion system. Their systems are reported to be able to produce ASTM-quality product within 1 week of start-up. The technology appears to be well-developed and well-supported. There are no royalty fees, but the non-disclosure requirements keep the proprietary technology secret. There are fully commercialized facilities throughout Europe. In the United States, one is owned and operated by Griffin Industries, located in Cold Springs, Kentucky.

Imperial Western Products Inc.'s technology is a two-stage, acid-base batch system process facility. There is only one facility in operation. It produces $10 \mathrm{million}$ gal $/ \mathrm{yr}$. It is unclear whether this technology can be scaled down to meet our capacity requirements, although the company claims it can. The output of this facility also meets ASTM standards. Imperial Western Products Inc.'s package for a stated cost of $\$ 100,000$ includes a list of drawings that would constitute the core of any new plant. These include:

- Process flow diagrams for methyl ester production, glycerin production, and methanol distillation and recovery

- Piping and instrumentation for the above

- Electrical one-line drawings

- A typical plant layout

- An equipment list

- A laboratory equipment list

- Laboratory procedures for quality control

- Production formulas

- A cost calculator.

Equipment sizing and specifications for all major components would be included. Because the drawings will likely be schematic, only some detailed drawings would need to be added to have a complete construction set, and such drawings would be relatively easy to obtain from any non-specialized engineering firm. However, the system designed for a 7-million-gal/yr facility will need to be downsized to meet our needs.

Imperial Western Products' package also includes a list of recommended laboratory equipment and full lab procedures, including biodiesel recipes for recycled oil feedstocks with various characteristics. It also includes a cost program that can quickly evaluate the processing cost of biodiesel made from a batch of recycled oil with a particular set of characteristics. Imperial Western Products tests every load of recycled oil before it will accept it, and this program helps it make that decision.

These programs and procedures seem to constitute Imperial Western Products' experience base in handling a variety of recycled oils over the past few years and could be quite valuable to a start-up such as ours. Finally, laboratory and process training at their plant is included. 
At $\$ 100,000$, Imperial Western Products' price is a good value because typical engineering plans are $6 \%$ or so of installed cost. Lead-time for the documentation set is 6 weeks.

Additional consulting at our site or by phone is available at $\$ 100 /$ hour.

Table 10. Commercial Biodiesel Technologies Available, 2004

\begin{tabular}{|c|c|c|c|}
\hline & $\begin{array}{l}\text { Imperial Western } \\
\text { Products Inc. }\end{array}$ & Biodiesel Industries & $\begin{array}{c}\text { Biodiesel } \\
\text { International }\end{array}$ \\
\hline Contact & $\begin{array}{l}\text { Curtis Wright, P.E. } \\
86600 \text { Avenue } 54 \\
\text { Coachella, CA } 92236 \\
\text { 760-398-0815 } \\
\text { cwright@imperialwesternprodu } \\
\text { cts.com }\end{array}$ & $\begin{array}{l}\text { Russell Teall } \\
\text { 435-1/2 El Sueno Road } \\
\text { Santa Barbara, CA } 93110 \\
\text { 805-689-9008 } \\
\text { rteall@aol.com }\end{array}$ & $\begin{array}{l}\text { Wilhelm Hammer } \\
\text { Ges.m.b.H, Parkring } \\
18 \\
\text { A-8074 } \\
\text { Grambach/Graz } \\
\text { +43 } 3164009100 \\
\text { bdi@biodiesel- } \\
\text { intl.com }\end{array}$ \\
\hline Technology & Batch plant & $\begin{array}{l}\text { No information, } 40-\mathrm{ft} \\
\text { container modulars }\end{array}$ & $\begin{array}{l}\text { Batch or batch- } \\
\text { continuous } \\
\text { processors }\end{array}$ \\
\hline Status & Commercial & Commercial & Commercial \\
\hline Feedstock & $\begin{array}{l}\text { Oils or yellow grease; up to } \\
40 \% \text { free fatty acids; moisture, } \\
\text { impurities, and unsaponified } \\
\text { materials }<2 \%\end{array}$ & $\begin{array}{l}\text { Vegetable oils and animal } \\
\text { fats }\end{array}$ & $\begin{array}{l}\text { Vegetable oils and } \\
\text { animal fats, free fatty } \\
\text { acids more than } 20 \%\end{array}$ \\
\hline Pretreatment & Filter and $\mathrm{H}_{2} \mathrm{O}$ reduction & $\begin{array}{l}\text { Unlimited free fatty acids or } \\
\text { moisture, impurities and } \\
\text { unsaponified materials; } \\
\text { pretreatment depends on } \\
\text { feedstock quality }\end{array}$ & Proprietary \\
\hline $\begin{array}{l}\text { Processing } \\
\text { costs }\end{array}$ & $\begin{array}{l}\$ 0.40-\$ 0.80 / g a l, \text { depending on } \\
\text { volume }\end{array}$ & $\begin{array}{l}\text { To be provided as part of } \\
\text { feasibility study and subject } \\
\text { to non-disclosure } \\
\text { agreement (NDA) }\end{array}$ & Subject to NDA \\
\hline Capacity & Up to 10 million gal/yr & $\begin{array}{l}\text { 3-million-gal/yr modular } \\
\text { units, scaleable }\end{array}$ & $\begin{array}{l}\text { 5-million-gal/yr batch, } \\
\text { larger with batch- } \\
\text { continuous }\end{array}$ \\
\hline Capital costs & $\$ 0.20-\$ 0.50 / \mathrm{gal}$ & $\begin{array}{l}\text { To be provided as part of } \\
\text { feasibility study and subject } \\
\text { to NDA }\end{array}$ & Not available \\
\hline Lead time & 3 Months & $\begin{array}{l}3 \text { months delivery, site } \\
\text { footprint and tankage } \\
\text { required in addition to } \\
\text { modular }\end{array}$ & 9 months \\
\hline Products & ASTM biodiesel, $90 \%$ glycerin & $\begin{array}{l}\text { ASTM biodiesel, glycerin } \\
\text { quality subject to feasibility } \\
\text { study and NDA }\end{array}$ & $\begin{array}{l}\text { ASTM biodiesel, } 80 \% \\
\text { glycerin, other } \\
\text { products include a } \\
\text { potassium phosphate } \\
\text { solid fertilizer }\end{array}$ \\
\hline Yield & $98 \%+$ & $\begin{array}{l}\text { To be provided as part of } \\
\text { feasibility study and subject } \\
\text { to NDA }\end{array}$ & Subject to NDA \\
\hline Warranties & Performance warranty & $\begin{array}{l}\text { Manufacturer } \\
\text { warranty ranges from 1-10 } \\
\text { years }\end{array}$ & Undetermined \\
\hline
\end{tabular}


Capital cost comparison (processing facility only, does not include collection system or installation cost): The collection system and installation cost will be similar for all systems.

Biodiesel Industries and Biodiesel International capital cost are estimated to be approximately $\$ 1 /$ gal of annual production.

$$
2,000,000 \mathrm{gal} * \$ 1.00 / \mathrm{gal}=\$ 2,000,000
$$

Imperial Western Product capital cost is approximately $\$ 0.50 /$ gal of annual production.

$$
2,000,000 \mathrm{gal} * \$ 0.50 / \mathrm{gal}=\$ 1,000,000
$$

We have not chosen a specific technology provider for our project. However, our technology choice will be based on the following considerations:

1. The capital costs must be competitive with the other batch-processing technologies available. Imperial Western has the lowest capital cost; however, whether it can scale down its technology at the capital cost its has quoted is an issue.

2. Given our aggressive timeline for project completion, Imperial Western and potentially Fitzsimmons Systems give us the best opportunity to meet our schedule requirements

3. The plant manager has to feel comfortable with the chosen technology, and, therefore, the choice has to be the technology that requires the least amount of time for him to become technically familiar. Although we will be conducting a search to permanently fill the plant manger role, Tom Leue's familiarity is an important factor, and Tom has recommended Imperial Western.

4. The plan is to choose a technology that has economies that make it cost-competitive with any licensed technology available. These should include:

- A modular nature that starts with two parallel processing trains and allows the future addition of more capacity as resource and market expansion allow

- A process that is not licensed by any particular interest (this may be difficult to accomplish) and a technology in the public domain

- A process that is demonstrably flexible for our feedstock

- A process technology that is similar to systems used by several U.S.-based biodiesel processors and can be supported by consulting experts

- Main components that are potentially available used from the chemical processing industry, further lowering costs. 
Table 11. Technology Choice Decision Matrix

\begin{tabular}{lccc}
\hline \multicolumn{1}{c}{ Parameter } & $\begin{array}{c}\text { Biodiesel } \\
\text { Industries }\end{array}$ & $\begin{array}{c}\text { Griffin Industries BioDiesel } \\
\text { International }\end{array}$ & $\begin{array}{c}\text { Imperial Western } \\
\text { Products }\end{array}$ \\
\cline { 2 - 4 } Laboratory support & 2 & 3 & 4 \\
Capital cost & 1 & 2 & 4 \\
Support services & 4 & 3 & 2 \\
Feedstock handling guidance & 3 & 2 & 4 \\
Length of experience & 3 & 4 & 4 \\
System capacity & 2 & 3 & 4 \\
Written documentation & 2 & 3 & 3 \\
Design flexibility & 2 & 4 & 3 \\
Order to completion & 4 & 4 & 4 \\
Assistance with collection setup & 3 & 3 & 2 \\
Plants up and running with & 3 & 4 & 1 \\
good references & & & 4 \\
Ability to invest & 4 & 1 & 44 \\
Other fees & 2 & 40 & \\
Totals: & 35 & & \\
& & &
\end{tabular}

\subsection{Pre-Process}

Oil receiving is designed for both 55-gal drum handling and occasional bulk truck deliveries. Because of the solidification of oil in cold weather, special heating systems are required. Using the low-cost hot water system, this heating requirement is not a large expense for the biorefinery. Bulk deliveries come in 7,000-gal trucks, which will be off-loaded to a heated receiving trough. Bulk oil should be de-watered and pre-cleaned so it may be transferred to bulk storage after simple straining. Drum receiving will use a loading dock built for this purpose. It is expected that drum deliveries will range from pickup-sized trucks to larger flatbed trucks. An adjustable-height loading ramp will accommodate these vehicles. Drums will be handled with an electric overhead hoist on a track to pick each drum individually and transfer the drum to an automated drum handling and cleaning system inside the adjacent hot room. The hot room will accommodate up to 150 drums and will be maintained at approximately $100^{\circ} \mathrm{F}$ through radiation and insulation. Drums will acclimatize overnight to melt the more saturated oils, such as palm oil, that would otherwise be solid at room temperature. 
The receiving station will be operated full time by the receiving assistant. The automated drum handling and cleaning system will take each opened drum and place it on an inverter over an open, heated vat. Oil will be drained first through a coarse screen. The residuals will be removed for disposal. The oil will then be further heated to thin its consistency while allowing the water to coalesce and fall to the container bottom. This water layer will be periodically released to a grease trap before ultimately going to the public sewer. The cloudy oil above the water level will be circulated through a filter press before being sent to bulk storage. The upper level of oil can be used with a recirculating pump to provide a warm oil stream to clean any remaining materials in the inverted drums. Drums are then drained and placed in storage for reuse.

Each drum is expected to take about 5 minutes to empty and clean. Ninety drums per day are processed for the daily resource requirement (no bulk purchases, no inventory). This will take about 7.5 hours of the available time of the receiving assistant.

Bulk storage of the cleaned vegetable oil is in five 12,000-gal mild steel tanks in a warmed storage room or in existing outside steel tanks that have been heated with a hot water coil and insulated. These tanks will have a floating draw-off system to always dispense the best available oil that is as clean and dry as is available. These tanks will undergo continuous sedimentation, and any accumulated water and crumb will be removed off the bottom.

In summary, feedstock pretreatment consists of RVO receiving, preheating, screening, dewatering, filtering, and bulk storage for further sedimentation. Side streams include wastewater disposal and crumb and particle disposal. Drum containers will be processed for reuse. Record keeping will be required for payments to grease farmers and for bulk deliveries.

\subsection{Process}

Our process will use the industry-standard acid-base, two-stage method. Production goals will be met with eight batches per week. Two batches will be produced per 8-hour day. All fluid handling will be by semi-automated batching systems. An onsite laboratory will be used for pre-and post-process quality control testing. Verification and calibration of process quality will be by testing and certification of selected batches by a laboratory qualified to do the series of ASTM tests.

Final processing of the product will consist of water wash, flash vaporization for drying, and final filtering. Byproduct handling consists of methanol recovery through distillation and then use of this material for process heat production in a specially designed boiler.

\subsection{Quality Control and Quality Assurance Program}

A quality assurance/quality control program is at the center of the proposed biodiesel production program. This document is an initial draft that is being prepared to answer particular questions about testing plans. This document will be expanded and adjusted frequently as this program is further developed. 


\subsubsection{Product Certification}

A nationally recognized laboratory capable of conducting all the tests should conduct certification of biodiesel fuel. We have established a relationship with Magellan Analytical (1090-A Sunshine Road, Kansas City, Kansas 66115; 913-621-3603).

Table 12. Detailed ASTM Requirements for Biodiesel (B-100) D-6751 ${ }^{5}$

\begin{tabular}{|c|c|c|c|c|}
\hline Property & Test Method $^{\underline{6}}$ & Limits & Units & Cost \\
\hline Flash point (closed cup) & D 93 & 130.0 & $\min { }^{\circ} \mathrm{C}$ & $\$ 43$ \\
\hline Water and sediment & D 2709 & $0.050 \max$ & $\%$ volume & $\$ 67$ \\
\hline Kinematic viscosity, $40^{\circ 7}$ & D 445 & $1.9-6.0 \mathrm{C}$ & $\mathrm{mm} 2 / \mathrm{s}$ & $\$ 69$ \\
\hline Sulfated ash & D 874 & $0.020 \max$ & $\%$ mass & $\$ 83$ \\
\hline Sulfur ${ }^{8}$ & D 5453 & $0.05 \max$ & $\%$ mass & $\$ 60$ \\
\hline Copper strip corrosion & D 130 & No. 3 & $\max$ & $\$ 48$ \\
\hline Cetane number & D 613 & 47 & $\min$ & $\$ 156$ \\
\hline Cloud point & D 2500 & Report $^{9}$ & ${ }^{\circ} \mathrm{C}$ & $\$ 40$ \\
\hline Carbon residue $^{10}$ & D 4530 & $0.050 \max$ & $\%$ mass & $\$ 53$ \\
\hline Acid number & D 664 & $0.80 \mathrm{max} \mathrm{mg}$ & $\mathrm{KOH} / \mathrm{g}$ & $\$ 43$ \\
\hline Free glycerin & D 6584 & $0.020 \%$ & mass & $\$ 89$ \\
\hline Total glycerin & D 6584 & $0.240 \%$ & mass & Incld \\
\hline Phosphorus content & D 4951 & $0.001 \max \%$ & mass & $\$ 45$ \\
\hline $\begin{array}{l}\text { Distillation temp, atmospheric } \\
\text { equivalent temp., } 90 \% \\
\text { recovered }\end{array}$ & D 1160 & 360 max & ${ }^{\circ} \mathrm{C}$ & $\$ 267$ \\
\hline
\end{tabular}

Total Cost: $\quad \$ 1,063$

To this should be added the cost of containers, shipping, and handling, or approximately $\$ 85$ additional, for a total of $\$ 1,150$. A complete set of tests will be run to establish process effectiveness.

This test series is required to certify the fuel. There is no expiration on this test, but it may be questioned if it is more than 1 year out of date. It is recommended that it be repeated at least annually.

Some of the ASTM tests are not effective for quality control purposes. These are the tests that are most important for process control:

5 To meet special operating conditions, modifications of individual limiting requirements may be agreed upon among purchaser, seller, and manufacturer.

6 The test methods indicated are the approved referee methods. Other acceptable methods are indicated in 5.1. 7 See X1.3.1. The $6.0 \mathrm{~mm} 2 / \mathrm{s}$ upper viscosity limit is higher than petrodiesel and should be taken into consideration when blending.

8 Other sulfur limits can apply in selected areas of the United States and in other countries.

9 The cloud point of biodiesel is generally higher than petrodiesel and should be taken into consideration when blending.

10 Carbon residue shall be run on the $100 \%$ sample (see 5.1.10). 
Table 13. Process Control Tests

\begin{tabular}{llllr}
\hline Property & Test Method & Limits & Units & Cost \\
\cline { 2 - 5 } & & & & \\
Water and sediment & D 2709 & $0.050 \mathrm{max}$ & $\%$ volume & $\$ 67$ \\
Kinematic viscosity, 40 & D 445 & $1.9-6.0 \mathrm{C}$ & $\mathrm{mm} 2 / \mathrm{s}$ & $\$ 69$ \\
Sulfur & D 5453 & $0.05 \mathrm{max}$ & $\% \mathrm{mass}$ & $\$ 60$ \\
Cloud point & D 2500 & Report & ${ }^{\circ} \mathrm{C}$ & $\$ 40$ \\
Free glycerin & D 6584 & $0.020 \%$ & mass & $\$ 89$ \\
Total glycerin & D 6584 & $0.240 \%$ & mass & Incld. \\
Acid number & D 664 & $0.80 \mathrm{max} \mathrm{mg}$ & $\mathrm{KOH} / \mathrm{g}$ & $\$ 43$ \\
& & & Total Cost: & $\$ 368$ \\
\hline
\end{tabular}

To this should be added the cost of containers, shipping, and handling, or approximately $\$ 85$ additional, for a total of $\$ 450$. Repeated testing service will reduce these costs at least $10 \%$, or to a budget of about $\$ 400$ per set.

These tests provide valuable information about operational effectiveness. It is recommended that they be repeated every 10 days or for $5 \%$ of the batches.

\subsubsection{In-House Testing}

Testing needs to be conducted in-house on each batch of biodiesel prepared. This testing will analyze:

- Free fatty acids

- Suspended solids

- Water

- Color

- Kinematic viscosity, $40^{\circ}$

- Cloud point

- Soap

- Specific gravity.

A correlation between these test results and the laboratory results allows us to calibrate the inhouse testing results and ASTM requirements. For example, with the most critical parameter - the completion of the transesterification reaction-De Filippis et al's "Transesterification Processes for Vegetable Oils: A Simple Control Method for Methyl Ester Content" demonstrates the ability to judge overall reaction quality using these simplified tests. The requirement is to establish quality standards for the simplified instruments based on laboratory tests. Through repeated laboratory testing, we will do this until we are assured we have adequate in-house controls in place.

Our budget for quality testing is $\$ 0.03 / \mathrm{gal}$, or about $\$ 51,000 / \mathrm{yr}$. This budget allows for all the testing as outlined above. 


\section{$9 \quad$ Regulatory and Policy Assessment}

\subsection{Taxes for Biodiesel}

Any biodiesel sold or bartered that does not contain a red dye is subject to federal use taxes. Dyed heating fuel and off-road fuel are not subject to any taxes at the wholesale level at this time, although sales taxes will apply for retail sale. Biodiesel is subject to the same taxes as standard diesel fuel, both on the state and federal level, minus special tax credits, if any. Other uses, such as biodiesel as a degreasing compound, are subject to sales taxes.

Massachusetts state road taxes are paid on each gallon sold wholesale or retail at the current rate of $\$ 0.21 / \mathrm{gal}$. This is paid monthly with the Massachusetts Department of Revenue form SFT-3, after obtaining an annual special fuel producers license. The license, surprisingly, is still available for a fee of $\$ 1 / \mathrm{yr}$.

In Vermont, B-100 is exempt from state road taxes, but any dilution of biodiesel, such as B20 , is not tax exempt. This is of moderate help, but the market for B-100 is limited in Vermont, and the tax exemption leaves a significant premium cost for that product. Federal road taxes are paid at the rate of $\$ 0.244 / \mathrm{gal}$ and are paid by the ultimate vendor of the fuel at the location where it is placed in the fuel tank. Therefore, wholesale distribution does not require a tax event for federal taxes but is required for retail sales. It is possible to sell bulk fuel to the ultimate user without collecting federal road tax if the buyer signs an Internal Revenue Service form to take responsibility for the applicable taxes. The first 400 gal of fuel per calendar quarter are exempt from reporting requirements. All payments need to be made electronically under new Internal Revenue Service rules.

\subsection{Potential Tax Credits}

In October 2004, President Bush signed into law the Foreign Sales Corporation and Extraterritorial Income Exclusion bill, also known as the "Jobs bill," which will go into effect at the beginning of 2005. We have not yet incorporated this into our financials. This is the breakdown, as best as we can interpret:

- Although it is often referred to as an "excise tax" credit, this doesn't tell the whole story. The excise tax in question is a $\$ 0.244$ federal tax imposed on every on-road gal of biodiesel. The "excise" portion of the law really only affects blends. It is a $\$ 0.01 / \%$ biodiesel tax credit for "oil seed" biodiesel and $\$ 0.005 / \%$ biodiesel for RVO biodiesel. This portion of the bill brings down pump prices on blends. Thus, a B-50 gets a $\$ 0.50 /$ gal rebate if it is made from oil seed B- 100 or a $\$ 0.25 /$ gal rebate if it is made from RVO B-100. The rebate applies to the distributor's entire tax bill and is not limited by the federal tax per gallon. 
- The income tax credit portion of the bill affects sellers and business users of biodiesel. It does reward B-100 use, to the tune of $\$ 0.50 /$ gal of recycled biodiesel and $\$ 1 / \mathrm{gal}$ of soy biodiesel. This reward is attained as a tax credit and will not result in a refund if the credit is bigger than the taxes owed. For example, a customer who uses 1,000 $\mathrm{gal} / \mathrm{yr}$ of recycled B-100 will get $\$ 500$ taken off of that year's taxes, assuming there is at least $\$ 500$ taxes owed. Although the seller is allowed to take this credit instead of the customer, the net effect would be less. Accordingly, the income tax credit portion of the bill cannot literally be seen as bringing down the price at the pump, although it is definitely a wonderful incentive for customers to take advantage of. Additionally, this portion of the bill directly benefits traditionally less-taxed or non-taxed users (e.g., agriculture).

Vermont and Maine recently provided tax credits for fuel generated in-state, and a concerted effort could be initiated to enact similar legislation in Massachusetts. This is being explored by the Massachusetts Department of Energy Resources. It is recommended that an effort to develop such legislation be discussed with one or more state senators. A coordinated effort should be enacted to identify coalitions and stakeholders that can be organized for greater effect. Alliance Energy reports it has initiated an effort to develop legislation for the reduction of Massachusetts' road taxes on biodiesel fuel. This project should assist in that effort.

\subsection{Department of Energy: EPAct}

EPAct was passed in 1992 to accelerate the use of alternative fuels in the transportation sector. The U.S. Department of Energy's primary goals are to decrease the nation's dependence on foreign oil and increase energy security through the use of domestically produced alternative fuels.

Compliance is required by state government and alternative fuel provider fleets that operate, lease, or control 50 or more light-duty vehicles within the United States. Of the fleet vehicles, 20 or more must be operated primarily within a metropolitan statistical area with a population of at least 250,000 people. The vehicles must also be centrally fueled or capable of being centrally fueled.

Fleets meeting all three of these requirements must make a certain percentage of their new vehicle purchases alternative fuel vehicles. EPAct recognizes the following alternative fuels: methanol, ethanol and other alcohols; blends of $85 \%$ or more of alcohol with gasoline; natural gas and liquid fuels domestically produced from natural gas; biodiesel; liquefied petroleum gas (propane); coal-derived liquid fuels; hydrogen; and electricity. 
Regarding the use of biodiesel to meet EPAct requirements, the Energy Conservation Reauthorization Act of 1998 allows federal, state, and alternative fuel provider fleets who must comply with EPAct and Executive Order 13149 to meet up to 50\% of their light-duty alternative-fueled vehicle purchase requirements with biodiesel. The biodiesel fuel use credit gives fleets and covered persons that are otherwise required under EPAct to purchase alternative fuel vehicles the option of purchasing and using 450 gal of biodiesel in vehicles in excess of 8,500 lbs. gross vehicle weight instead of purchasing an alternative fuel vehicle. Fleets must purchase and use the equivalent of $450 \mathrm{gal}$ of pure biodiesel in a minimum of a $20 \%$ blend to earn one alternative fuel vehicle credit.

In our area, Hampshire, Hampden, and part of Franklin counties are within designated "metropolitan statistical areas." However, we have only one state entity that falls under EPAct requirements: the University of Massachusetts. The other large federal installation in our area that might be concerned is Westover Air Force Base in Chicopee; however, law enforcement, emergency, and military and military tactical vehicles are exempt from this requirement.

\subsection{U.S. Environmental Protection Agency}

Biodiesel sold for over-the-road use (i.e., in cars and trucks) must meet the federal Environmental Protection Agency (EPA) requirement. This is essentially limited to a registration process, which, in turn, requires compliance with 40 CFR 79, Registration of Fuels and Fuel Additives. This requires health effects testing compliance, which can be an expensive and burdensome process that costs more than $\$ 1$ million by Environmental Protection Agency estimate. There is an exemption for "small producers" with annual fuel sales less than $\$ 10$ million, whereby the Tier 2 tests are not required, which potentially reduces the test costs to approximately $\$ 100,000$. To date, only the National Biodiesel Board has completed all of these tests. The Environmental Protection Agency requirements may also be met by demonstrating the rights to use the National Biodiesel Board testing have been purchased from the National Biodiesel Board. This is accomplished most effectively by joining the National Biodiesel Board. See the Section on the National Biodiesel Board under Legal Implications. The Environmental Protection Agency does not test fuel or fuel production facilities.

Undertaking in-house Tier 1 tests using both private and public funds may also further the development of a biorefinery franchise system and yield a large return on the investment. Further information is available upon request. 


\subsection{U.S. Department of Agriculture}

Environmental Protection Agency-registered biodiesel producers are eligible to register with the U.S. Department of Agriculture for Commodity Credit Program payments. This is a onetime credit for increases in biodiesel production from the previous quarter. The payment amount may vary; in 2004 , first -quarter payments amounted to $\$ 1.558 /$ gal of new production. Small additional payments are being made on base production for biodiesel, but these amounts are set to decline rapidly to just $\$ 0.15 / \mathrm{gal}$ in 2005 ( $\$ 300,000$ for our project) and to disappear after that. Future payments are not guaranteed beyond 2006, and in 2006, only payments for capacity expansion are allowed. These credits will provide substantial cost recovery for the capital expenditure, after the system is operational and the program requirements are met. Payments are made on a quarterly basis and would be used to offset debt.

New U.S. Department of Agriculture Bio-Based Procurement Rules, issued in draft as of Feb. 17,2004 , require federal government agencies to purchase fuel additives using biodiesel whenever available, upon recommendation of the secretary of the department. Final guidelines have not been formulated for this policy but are likely to further promote the use of biodiesel for federal agencies.

\subsection{Massachusetts Department of Environmental Protection}

The Department of Environmental Protection is the regulator of air emissions, water discharge, and site environmental protection.

- Air emissions: Initial calculations show a positive return on the use of a biodieselfired co-generator for both electric and hot water production. The proposed size of approximately $30 \mathrm{~kW}$ is below regulatory concern. No open chemical storage keeps volatile organic compounds from being an issue.

- Water discharge: Discharge of process wastewater to the sewer does not appear to require permits or pre-treatment, according to a conversation with Sandy Shields at the Greenfield Wastewater Treatment Plant.

- Site protection: The bulk storage of biodiesel will be in bermed storage areas or in double-walled tanks to avoid the possibility of release into the environment. All chemical storage will be in compliance with applicable regulations.

\subsection{Fire Codes}

Fire codes are implemented by the local fire marshal, using the National Fire Protection Association and state codes as guidelines. Biodiesel is classified as a Class IIIc combustible liquid. The National Fire Protection Association fire code does not include Class IIIc fuels but is limited to the more restrictive IIIb codes for more flammable liquids. However, the Class IIIb codes are used as a ceiling to the most restrictive conditions likely to be imposed. These are the standards for complying with fire codes, and they are not expected to be burdensome or costly for this construction and operation project. 


\subsection{Local Zoning}

The proposed biorefinery would be classified as a light industry in most municipalities. An ideal property for development would be one that previously was used for petroleum distribution. It is economically important to have permits for retail sales of biodiesel. The zoning is usually denominated as general industrial or special industrial and appears to be consistent with the intentions of the proposed biorefinery.

Local zoning officials may need careful education about biodiesel. Based on ignorance, some may think it is not a good neighbor. Unlike rendering companies, a biorefinery has no odor emissions or water or air pollution, does not have any chemical emissions, and is safer than the storage of petroleum in terms of fire hazards. The chemicals stored on site, lye and alcohol, do not exceed Community Right to Know Law threshold quantities.

\subsection{Legal Implications: Liability Considerations}

Biodiesel fuel that meets the ASTM D-6751 standard works in any unmodified diesel engine. Engine manufacturers do not provide warranty coverage for biodiesel or any other fuel, but its use in engines decreases wear on engine components such as injector pumps and piston rings and does not void warranties. Most engine manufacturers are variously recommending a maximum percentage of B-05, B-10, or B-20. Some states, such as Minnesota, mandate an increasing percentage of biodiesel fuel in every gallon of diesel fuel statewide; this is also the situation throughout Europe. Current mandates are usually B-02, and they will be rising up to B- 20 by the year 2020 . 


\section{Attachment 1: Business Development Timeline}

\begin{tabular}{lrrr}
\hline Timeline & \multicolumn{2}{c}{ Anything shaded is an assumption. } \\
& $\begin{array}{r}\text { Weeks Required } \\
\end{array}$ & Started On & Completed By \\
\cline { 2 - 4 } & & & \\
Obtain location & 4 & 1-Nov-04 & 29-Nov-04 \\
Obtain permits & 26 & $29-N o v-04$ & 30-May-05 \\
Secure financing & 13 & 1-Nov-04 & 31-Jan-05 \\
Equipment ordered and delivered & 13 & $31-J a n-05$ & 2-May-05 \\
Installation & 6 & 2-May-05 & 13-Jun-05 \\
Testing & 2 & 13-Jun-05 & 27-Jun-05 \\
Production start & 1 & 27-Jun-05 & 4-Jul-05 \\
At "full" production capacity & 13 & 4-Jul-05 & 3-Oct-05 \\
& & & \\
\hline
\end{tabular}




\section{Attachment 2: Financials}

\section{ASSUMPTIONS}

Processor Info

Production Info

gal of $\mathrm{BD} / \mathrm{gal}$ of feedstock gal of glycerin/gal of BD Amount Used Internally gal of glycerin disposed of/gal of BD Methanol Recovery

\section{Pricing}

Wholesale Mark-up over costs \$ Retail Markup \$ Federal Tax \$ State Tax-Massachusetts \$ Competitive Wholesale Price \$

Diesel Wholesale Cost $\$$ $\%$ sold retail Selling Price: Glycerin \$ USDA Credit for New Production \$ Tax Credit/gallon

Source of Feedstock

Fish Farm partnership Grease Farming

Bulk Purchased(incl transportation)

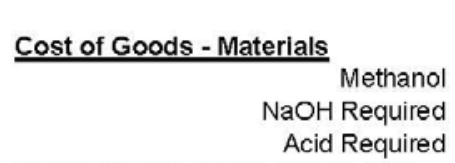

Nitrogen for methanol storage (incl breathing losses

Red Dye for heating oil Electricity Fuel Required Water Required Sewer Required Water Treatment Unused oil disposal cost Filters Required Quality testing
Anything shaded is an assumption.

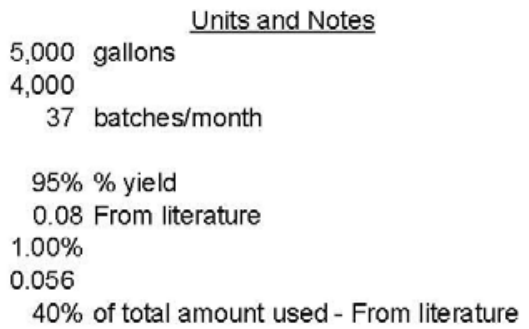

\begin{tabular}{|c|c|c|}
\hline \multicolumn{2}{|l|}{ Amtweek (gallons) } & Cost/Gallon \\
\hline \multirow{2}{*}{$\begin{array}{l}6,000 \\
35 \% \text { of remainder }\end{array}$} & & $\$ 0.2500$ \\
\hline & $35 \%$ of remainder & $\$ 0.3000$ \\
\hline \multicolumn{2}{|c|}{$65 \%$ of remainder } & $\$ 0.8000$ \\
\hline \multicolumn{3}{|l|}{ Amt needed / gal of } \\
\hline Biodiesel & Units & Unit Cost \\
\hline 0.20 & $\overline{\text { gal }}$ & 1.050 \\
\hline 0.012 & $\$ / \mathrm{lb}$ & 0.900 \\
\hline 0.015 & $\$ / \mathrm{lb}$ & 0.180 \\
\hline 0.210 & \$/gal & 0.120 \\
\hline 0.15 & KWh & 0.120 \\
\hline 0.10 & $\$ / \mathrm{gal}$ & 0.160 \\
\hline 0.30 & $\$ / 1000 \mathrm{gal}$ & 2.559 \\
\hline 0.30 & $\$ / 1000 \mathrm{gal}$ & 3.986 \\
\hline & per gallon & 0.0050 \\
\hline & ga/ton & 0.011 \\
\hline 0.0020 & $\$ /$ filter unit & 4.000 \\
\hline & per gallon & 0.030 \\
\hline
\end{tabular}

Cost/Gallon

0.1260

0.0108

0.0027

0.0252

0.0180

0.0160

0.0008

0.0012

0.0050

0.0110

0.0080

0.0300 


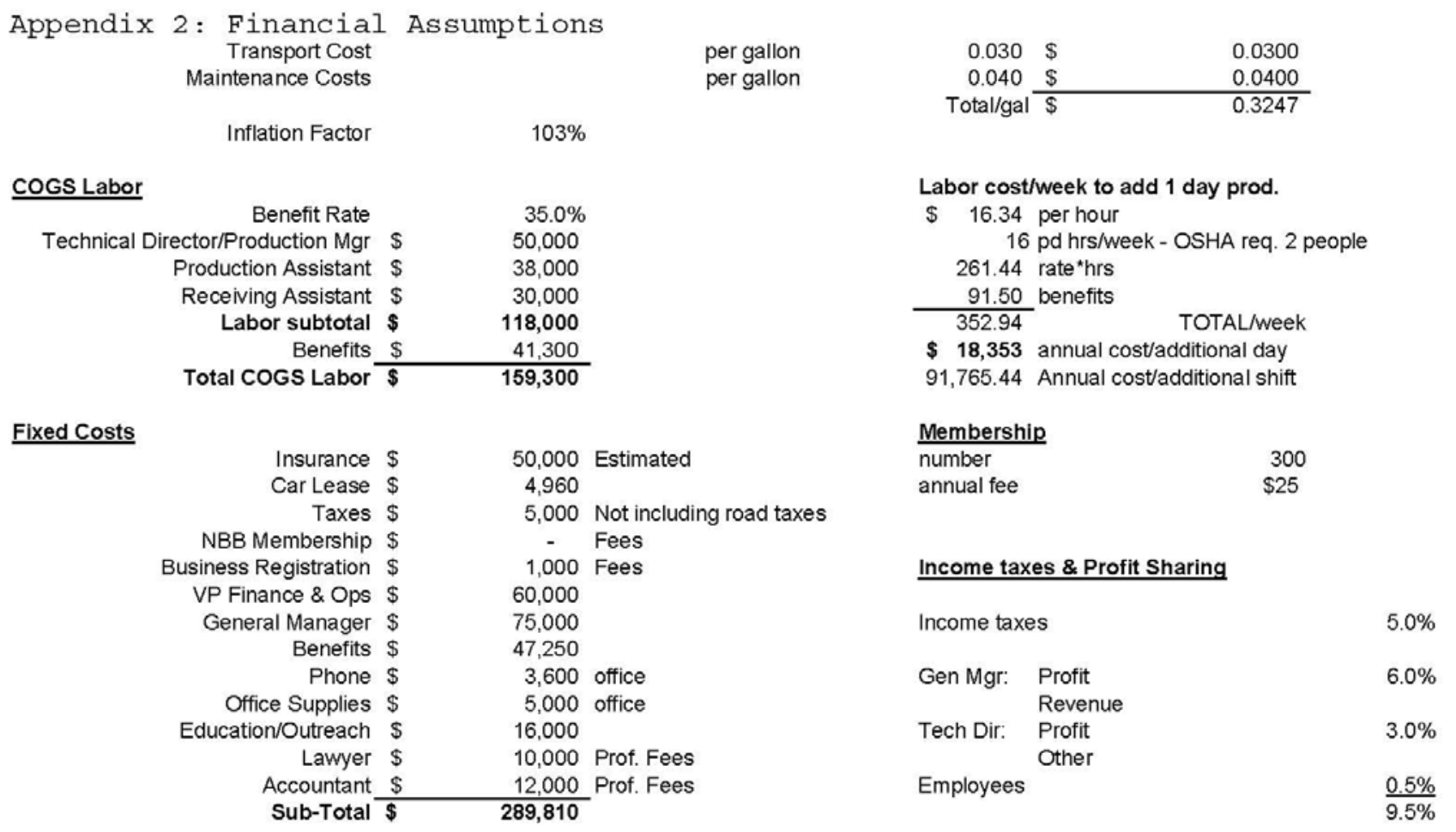

\section{Sales Expenses}

Half-time Customer Service/Clerical \$ $\$ \quad 15,000$ Includes retail operation.

Benefits \$ 5,250

Marketing/Advertising $\$ \quad 60,000$

Sub-Total $\$ \quad \mathbf{8 0 , 2 5 0}$

Financing

\begin{tabular}{|c|c|c|c|c|}
\hline $\begin{array}{r}\% \text { of Financing fr/ Investors } \\
\text { Grants (amt.) }\end{array}$ & $\begin{array}{r}70 \% \\
250,000\end{array}$ & & & \\
\hline Loan Terms & Commercial RE & Business Loan & Line of Credit & 2nd Business Loan \\
\hline Rate & $7.5 \%$ & $8.5 \%$ & $8.5 \%$ & $8.5 \%$ \\
\hline Term & 20 & 7 & 20 & 7 \\
\hline Max. LTV & $80 \%$ & $75 \%$ & & $75 \%$ \\
\hline Max. Loan Size & 356,000 & $1,580,250$ & & $6,000,000$ \\
\hline Likely loan size & 356,000 & 292,405 & 450,000 & $6,000,000$ \\
\hline Interest - Year 1 & $26,700.00$ & $24,854.43$ & $38,250.00$ & $510,000.00$ \\
\hline Monthly Payment & $\$ 2,867.91$ & $\$ 4,630.67$ & $\$ 3,905.20$ & $\$ 95,018.91$ \\
\hline
\end{tabular}




\section{Capital Costs}

\author{
Start-up Costs \\ Lawyer/Prof. Fees \\ Accounting System \\ Brand Startup \\ Interim Project Development
}

Site Development

Permits
On-site Testing Lab
Building \& Land Acquisition

Site/Building Improvements

Collection/Cleaning System

Collection Barrels

Automated unload/cleaning system

Process Technology

Processor

$2,000,000$

gallon/year capacity

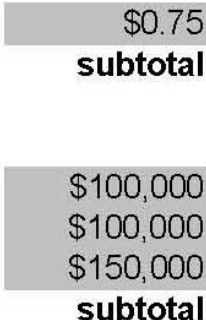

1"

Sub-Total

Contingency

TOTAL

Description

Unit Cost

$\$ 30,000$

$\$ 25,000$

$\$ 40,000$

$\$ 102,000$

subtotal

$\$ 20,000$

$\$ 25,000$

$\$ 250,000$

$\$ 150,000$

subtotal

55 gal drum

ea.

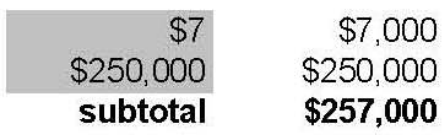

subtotal $\$ 257,000$

Finished Product Distribution

Tanks
Dispensing
Retail Fuel Pump
1

1
$\$ 25,000$

$\$ 250,000$

$\$ 150,000$

$\$ 445,000$

$\$ 1,500,000$

$\$ 1,500,000$

$\$ 100,000$

$\$ 100,000$

$\$ 150,000$

$\$ 350,000$

$\$ 2,749,000$

$15 \% \quad \$ 412,350$

$\$ 3,161,350$

Capital Cost Ratio

\$ investment/gallon capacity

1.58

Additional Production Capacity

$8,000,000$

gallon/year capacity

$\$ 1.00$

$\$ 8,000,000$ 


\section{Sources \& Uses of Capital}

Uses of Proceeds

Prior Investments

Start-up Costs

Site Acquisition \& Development

Collection/Cleaning System

Processing Plant

Distribution Equipment

Contingency

Working Capital
Amount

50,000

197,000

445,000

257,000

$1,500,000$

350,000

Sub-Total

$2,799,000$

412,350

450,000 based on $80 \%$ of max feedstock

TOTAL

$3,661,350$
Notes

investment

from Capital Costs

from Capital costs

from Capital costs

from Capital costs

from Capital costs

from Capital costs

Amount

$\%$ of total \% of equity

Sources

Equity

Private Investors

USDA Grant

NREL Contract

\begin{tabular}{rr}
$1,912,945$ & $52.2 \%$ \\
250,000 & $6.8 \%$ \\
400,000 & $10.9 \%$ \\
\hline $2,562,945$ & $70.0 \%$
\end{tabular}

$74.6 \%$

$9.8 \%$

$15.6 \%$

Real Estate Loan

Debt

Business Loan

Sub-Total

356,000

$9.7 \%$ lesser of total less investor or me

292,405

$8.0 \%$

Working Capital LOC

\begin{tabular}{rr}
356,000 & $9.7 \%$ lesser of total less investor or me \\
292,405 & $8.0 \%$ \\
450,000 & $12.3 \%$ \\
Sub-Total & $1,098,405$ \\
\cline { 2 - 2 } & $30.0 \%$ \\
\hline \hline
\end{tabular}

Monthly Loan Payment

Total P, P \& E

$\$ 11,404$

$\$ 2,964,350$

Depreciation/month - 15 yr s/l

$\$ 16,469$ 
Production Costs Analysis

Capacity
Utlilization
Batch Size (gallons)
Batches/Day
Days Operation/Week
Batches/Year
Production Volume/week
Production Volume/Year
Feedstock Source
Feedstock Required
Back Haul Farmers
from grease farming
purchased
Cost/Gallon
Raw Materials/Batch
Oil (gallons)
Cost of Goods Sold (per batch)
Oil
Other Materials
Labor Cost/Batch
TOTAL COGS/Batch
COGS/GALLON
Fixed Expenses
Management
Sales
Interest expense - year 1
Depreciation - 15 yr s/
Total Fixed Costs

$\begin{array}{rrrrrr}85 \% & 40 \% & 60 \% & 85 \% & 100 \% & 85 \% \\ 4,000 & 4,000 & 4,000 & 4,000 & 4,000 & 4,000 \\ 1 & 2 & 2 & 2 & 2 & 6 \\ 5 & 5 & 5 & 5 & 5 & 530 \\ 221 & 208 & 312 & 442 & 520 & 40,800 \\ 17,000 & 16,000 & 24,000 & 34,000 & 40,000 & 2,121,600 \\ 884,000 & 832,000 & 1,248,000 & 1,768,000 & 2,080,000 & 44.2 \\ 18.4 & 17.3 & 26.0 & 36,8 & 43.3 & 2,233,263 \\ 930,526 & 875,789 & 1,313,684 & 1,861,053 & 2,189,474 & 312,000 \\ 312,000 & 312,000 & 312,000 & 312,000 & 312,000 & 672,442 \\ 216,484 & 197,326 & 350,589 & 542,168 & 657,116 & 1,248,821 \\ 402,042 & 366,463 & 651,095 & 1,006,884 & 1,220,358 & 0.572 \\ 0.499 & 0.491 & 0.536 & 0.562 & & \\ & & & & & \end{array}$

\begin{tabular}{|c|c|c|c|c|c|c|c|c|c|c|c|}
\hline$\$$ & $2,102.17$ & $\$$ & $2,069.08$ & $\$$ & $2,256.58$ & $\$$ & $2,366.87$ & $\$$ & $2,406.58$ & $\$$ & $2,410.99$ \\
\hline$\$$ & $1,298.65$ & $\$$ & $1,298.65$ & $\$$ & $1,298.65$ & $\$$ & $1,298.65$ & $\$$ & $1,298.65$ & $\$$ & $1,298.65$ \\
\hline$\$$ & 720.81 & $\$$ & 765.87 & $\$$ & 510.58 & $\$$ & 360.41 & $\$$ & 306.35 & $\$$ & 334.94 \\
\hline$\overline{\$}$ & $4,121.64$ & $\overline{\$}$ & $4,133.60$ & $\$$ & $4,065.81$ & $\$$ & $4,025.93$ & $\$$ & $4,011.58$ & $\$$ & $4,044.59$ \\
\hline$\$$ & 1.030 & $\$$ & 1.033 & $\$$ & 1.016 & $\$$ & 1.006 & $\$$ & 1.003 & $\$$ & 1.011 \\
\hline
\end{tabular}

\begin{tabular}{lrlrlrlrlrlr}
$\$$ & 289,810 & $\$$ & 289,810 & $\$$ & 289,810 & $\$$ & 289,810 & $\$$ & 289,810 & $\$$ & 289,810 \\
$\$$ & 80,250 & $\$$ & 80,250 & $\$$ & 80,250 & $\$$ & 80,250 & $\$$ & 80,250 & $\$$ & 80,250 \\
$\$$ & 93,003 & $\$$ & 93,003 & $\$$ & 93,003 & $\$$ & 93,003 & $\$$ & 93,003 & $\$$ & 93,003 \\
$\$$ & 209,123 & $\$$ & 209,123 & $\$$ & 209,123 & $\$$ & 209,123 & $\$$ & 209,123 & $\$$ & 209,123 \\
\hline$\$$ & $\mathbf{6 7 2 , 1 8 7}$ & $\$$ & $\mathbf{6 7 2 , 1 8 7}$ & $\mathbf{6}$ & $\mathbf{6 7 2 , 1 8 7}$ & $\mathbf{\$}$ & $\mathbf{6 7 2 , 1 8 7}$ & $\mathbf{\$}$ & $\mathbf{6 7 2 , 1 8 7}$ & $\mathbf{\$}$ & $\mathbf{6 7 2 , 1 8 7}$
\end{tabular}




\begin{tabular}{|c|c|c|c|c|c|c|c|c|c|c|c|c|}
\hline $\begin{array}{l}\text { Total Production Costs/Gallon } \\
\text { aka Breakeven Price/Gallon }\end{array}$ & $\$$ & 1.791 & $\$$ & 1.841 & $\$$ & 1.555 & $\$$ & 1.387 & $\$$ & 1.326 & $\$$ & 1.328 \\
\hline \multicolumn{13}{|l|}{ RATIOS } \\
\hline Operating Capacity & & $44 \%$ & & $42 \%$ & & $62 \%$ & & $88 \%$ & & $104 \%$ & & $106 \%$ \\
\hline Total fixed costs per batch & & 3,042 & & 3,232 & & 2,154 & & 1,521 & & 1,293 & & 1,267 \\
\hline Total production costs per batch & & 4,122 & & 4,134 & & 4,066 & & 4,026 & & 4,012 & & 4,045 \\
\hline Total costs per batch & & 7,163 & & 7,365 & & 6,220 & & 5,547 & & 5,304 & & 5,312 \\
\hline Breakeven price/gallon & $\overline{\$ \$}$ & 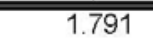 & $\overline{\$ S}$ & $\overline{1.841}$ & $\overline{\mathrm{S}}$ & 1.555 & $\overline{\$ \$}$ & 1.387 & $\overline{\$ \$}$ & 1.326 & $\overline{\$ \$ \$}$ & $\overline{1.328}$ \\
\hline Feedcost cost per gal & $\$$ & 0.499 & $\$$ & 0.491 & $\$$ & 0.536 & $\$$ & 0.562 & $\$$ & 0.572 & $\$$ & 0.573 \\
\hline Fixed cost per gal & $\$$ & 0.760 & $\$$ & 0.808 & $\$$ & 0.539 & $\$$ & 0.380 & $\$$ & 0.323 & $\$$ & 0.317 \\
\hline Non feedstock COGS & $\$$ & 0.531 & $\$$ & 0.542 & $\$$ & 0.481 & $\$$ & 0.444 & $\$$ & 0.431 & $\$$ & 0.439 \\
\hline Total nonfeedstock cost/gal & $\$$ & 1.292 & $\$$ & 1.350 & $\$$ & 1.019 & $\$$ & 0.825 & $\$$ & 0.754 & $\$$ & 0.755 \\
\hline \multicolumn{13}{|l|}{ BREAK-EVEN } \\
\hline if targetted Gross Margin is & & $40 \%$ & & & & & & & & & & \\
\hline Break-even sales are & $\$$ & $1,680,467$ & $\$$ & $1,680,467$ & $\$$ & $1,680,467$ & $\$$ & $1,680,467$ & $\$$ & $1,680,467$ & $\$$ & $1,680,467$ \\
\hline Price/Gallon produced must be & $\$$ & 2.931 & $\$$ & 3.053 & $\$$ & 2.363 & $\$$ & 1.957 & $\$$ & 1.811 & $\$$ & 1.803 \\
\hline at Targetted Price & $\$$ & 2.95 & $\$$ & 3.04 & $\$$ & 2.57 & $\$$ & 2.29 & $\$$ & 2.19 & $\$$ & 2.19 \\
\hline Break-even Volume & & 195,433 & & 184,857 & & 259,177 & & 325,942 & & 356,423 & & 355,395 \\
\hline at Fixed Price & $\$$ & 2.10 & $\$$ & $\begin{array}{r}2.10 \\
\end{array}$ & $\$$ & $\begin{array}{r}2.10 \\
587.388\end{array}$ & $\$$ & 2.10 & $\$$ & $\begin{array}{r}2.10 \\
\end{array}$ & $\$$ & 2.10 \\
\hline Break-even Volume & & $1,035,221$ & & $1,237,377$ & & 587,388 & & 448,731 & & 413,585 & & 414,611 \\
\hline
\end{tabular}


Appendix 2: Summary Profit and Loss Statement

\begin{tabular}{|c|c|c|c|c|c|c|c|c|c|c|}
\hline & 2005 & & 2006 & & 2007 & & 2008 & & 2009 & \\
\hline rease Farm oil Delivered (gallon: & 128,800 & & 628,200 & & $1,118,200$ & & $2,044,200$ & & $2,490,600$ & \\
\hline Purchased oil (gallons) & 230,000 & & $2,650,000$ & & $7,600,000$ & & $7,275,000$ & & $6,750,000$ & \\
\hline Batches Made & 80 & & 886 & & 2,210 & & 2,210 & & 2,210 & \\
\hline Feedstock Gallons Used & 336,842 & & $3,730,526$ & & $9,305,263$ & & $9,305,263$ & & $9,305,263$ & \\
\hline Gallons Produced & 320,000 & & $3,544,000$ & & $8,840,000$ & & $8,840,000$ & & $8,840,000$ & \\
\hline Gal. Sold & 170,280 & & $2,922,480$ & & $8,751,600$ & & $8,751,600$ & & $8,751,600$ & \\
\hline Gal Used Internally & 3,200 & & 35,440 & & 88,400 & & 88,400 & & 88,400 & \\
\hline Income statement & 2005 & & 2006 & & 2007 & & 2008 & & 2009 & \\
\hline \multicolumn{11}{|l|}{ REVENOES } \\
\hline Wholesale SALES & 339,709 & $94 \%$ & $5,721,311$ & $93 \%$ & $16,312,756$ & $94 \%$ & $16,173,095$ & $94 \%$ & $15,995,596$ & $94 \%$ \\
\hline Retail SALES & 23,873 & $7 \%$ & 403,993 & $7 \%$ & $1,166,622$ & $7 \%$ & $1,159,272$ & $7 \%$ & $1,149,930$ & $7 \%$ \\
\hline USDA Credit & - & $0 \%$ & 42,570 & $1 \%$ & - & $0 \%$ & - & $0.0 \%$ & - & $0 \%$ \\
\hline Membership Fees & - & $0 \%$ & - & $0 \%$ & - & $0 \%$ & - & $0.0 \%$ & - & $0 \%$ \\
\hline By-product Income & $(2,912)$ & $-1 \%$ & $(32,250)$ & $-1 \%$ & $(80,444)$ & $0 \%$ & $(80,444)$ & $-0.5 \%$ & $(80,444)$ & $0 \%$ \\
\hline TOTAL INCOME & 360,670 & $100 \%$ & $6,135,624$ & $100 \%$ & $17,398,934$ & $100 \%$ & $17,251,922$ & $100 \%$ & $17,065,082$ & $100 \%$ \\
\hline
\end{tabular}

EXPENSES

COST OF GOODS SOLD (COGS)

$\begin{array}{lllllllllll}\text { Feedstock } & 217,600 & 60 \% & 2,293,340 & 37 \% & 6,400,340 & 37 \% & 6,418,140 & 37 \% & 6,132,060 & 36 \%\end{array}$

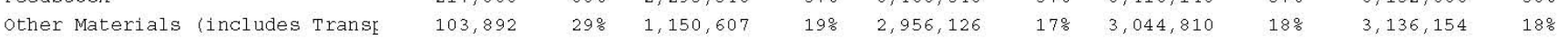

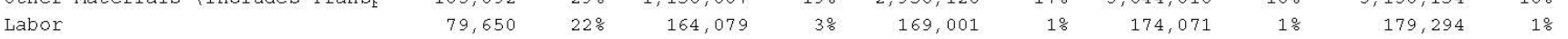

$\begin{array}{llllllllll}\text { Extra Day Labor } & 4,585 & 1 \% & 18,339 & 0 \% & 18,339 & 18,339 & 0 \% & 18,339 & 0 \%\end{array}$

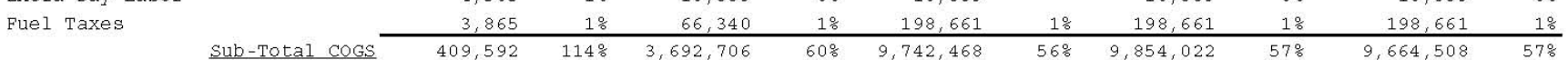

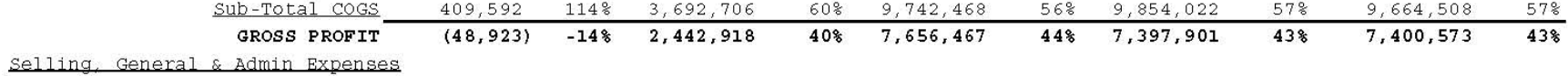

$\begin{array}{llllllllll}\text { Management Expenses } & 249,905 & 69 \% & 289,810 & 5 \% & 298,505 & 2 \% & 307,460 & 2 \% & 316,684\end{array}$

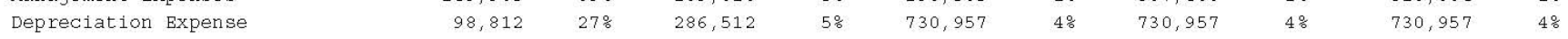

\begin{tabular}{lrrrrrrrrr}
56,125 & $16 \%$ & 97,863 & $2 \%$ & 137,910 & $1 \%$ & 133,895 & $1 \%$ & 131,449 & $1 \%$ \\
\hline & $5 a l e s$ & $\%$ & $\%$
\end{tabular}

\begin{tabular}{l} 
Sub-total S, G \& A EXPENSES \\
\cline { 2 - 7 } Taxes
\end{tabular}

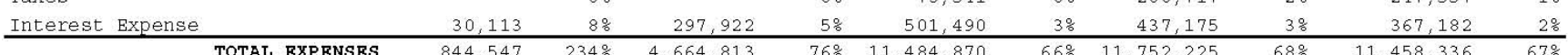

\begin{tabular}{|c|c|c|c|c|c|c|c|c|c|c|}
\hline TOTAL EXPENSES & 844,547 & $234 \%$ & $4,664,813$ & $76 \%$ & $11,484,870$ & $66 \%$ & $11,752,225$ & $68 \%$ & $11,458,336$ & $67 \%$ \\
\hline OFIT (LOSS) & $(483,878)$ & $-134 \%$ & $1,470,811$ & $24 \%$ & $5,914,065$ & $34 \%$ & $5,499,697$ & $32 \%$ & $5,606,745$ & $33 \%$ \\
\hline Disbursed as Profit Sharing & - & & - & & 139,727 & & 548,562 & & 470,358 & \\
\hline
\end{tabular}

Class "B" Equity Holders Dividends

Retained Earnings

$(483,878)$

142,176

740,924

$(598,748)$

43,229

$1,470,811$

$5,774,338$

Total operating Disbursements

Net Operating Cash

Annual Loan Payments (w/o LOC)

$$
\begin{array}{r}
4,796,604 \\
4,021,495 \\
775,108 \\
660,096
\end{array}
$$

$$
\begin{array}{r}
17,522,729 \\
10,118,456 \\
7,404,273 \\
1,230,210
\end{array}
$$

$4,760,137$

$4,574,885$

$\begin{array}{rr}17,243,290 & 17,088,082 \\ 10,233,137 & 10,048,534 \\ 7,010,153 & 7,039,548 \\ 1,230,210 & 1,230,210\end{array}$

RATIOS

Gross Margin

Net Margin

Debt to Equity

$-14 \%$
$-134 \%$
$47 \%$

0.18
$(13.85)$
$-18.9 \%$
$-36.4 \%$

$40 \%$
$24 \%$
$131 \%$

0.47
1.17
$57 \%$
$24.0 \%$
$\$ 10,533,898$

$44 \%$

$34 \%$

$43 \%$

$32 \%$

$31 \%$

$43 \%$

Asset Turnover Ratio (net of credit \& fees)

(13.85)

Return on Invested Capital (if paid)

Return on Ave. Equity

$-36.4 \%$

$1.17-0.64$

6.02
$127 \%$

$37.6 \%$

0.48

5.70

$100 \%$

$17.8 \%$

$34.79 \%$

Payback Yrs. 
Appendix 2: Balance Sheet

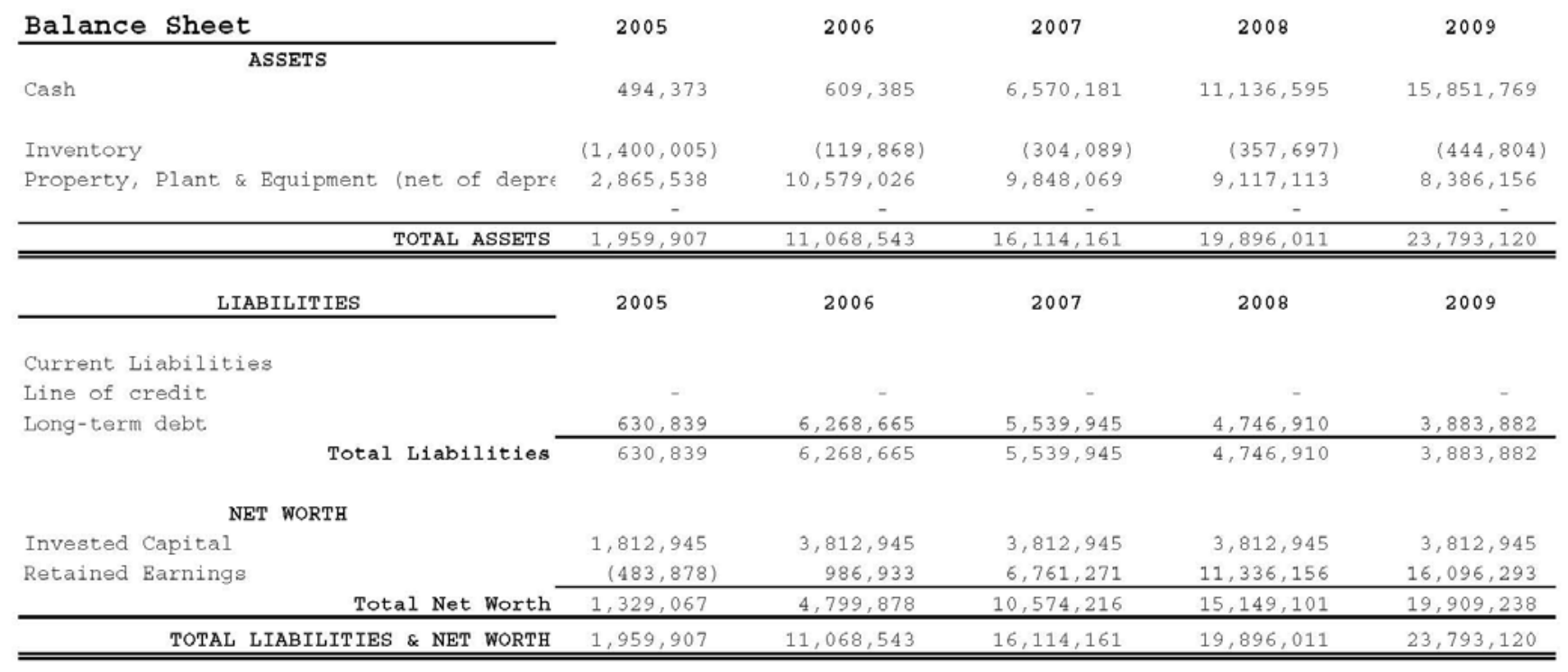


Appendix 2: Capital Cost Summary

\section{Capital Costs}

\author{
Start-up Costs \\ Lawyer/Prof. Fees \\ Accounting System \\ Brand Startup \\ Interim Project Development
}

Site Development

Permits
On-site Testing Lab
Building \& Land Acquisition
Site/Building Improvements

Collection/Cleaning System

Collection Barrels

Automated unload/cleaning system

Process Technology

Processor

$2,000,000$

gallon/year capacity

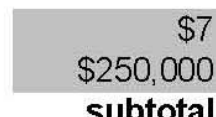

Finished Product Distribution

Tanks
Dispensing
Retail Fuel Pump

Tanks

Retail Fuel Pump subtotal

$\$ 0.75$

subtotal

$\$ 1,500,000$

$\$ 1,500,000$

$\$ 20,000$

$\$ 25,000$

$\$ 250,000$

$\$ 150,000$

$\$ 445,000$

$\$ 7,000$

$\$ 250,000$

$\$ 257,000$

$\$ 100,000$

$\$ 100,000$

$\$ 150,000$

subtotal

$\$ 100,000$

$\$ 100,000$

$\$ 150,000$

$\$ 350,000$

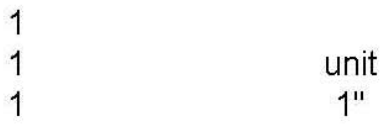

Sub-Total

Contingency

TOTAL

$\$ 2,749,000$

$15 \% \quad \$ 412,350$

$\$ 3,161,350$

Capital Cost Ratio

Additional Production Capacity

$8,000,000$ gallon/year capacity

1.58

\$ investment/gallon capacity

$\$ 1.00 \quad \$ 8,000,000$ 


\section{Production Costs Analysis}

\begin{tabular}{|c|c|c|c|c|c|c|c|c|c|c|c|c|c|c|c|c|}
\hline \multicolumn{17}{|l|}{ Capacity } \\
\hline Utlilization & \multicolumn{3}{|c|}{$85 \%$} & \multicolumn{2}{|l|}{$40 \%$} & \multicolumn{2}{|l|}{$60 \%$} & \multicolumn{2}{|l|}{$85 \%$} & \multicolumn{2}{|l|}{$100 \%$} & \multicolumn{2}{|l|}{$85 \%$} & \multicolumn{2}{|l|}{$100 \%$} & \multirow{2}{*}{$\begin{array}{r}85 \% \\
4,000\end{array}$} \\
\hline Batch Size (gallons) & \multicolumn{3}{|c|}{4,000} & \multicolumn{2}{|l|}{4,000} & \multicolumn{2}{|l|}{4,000} & \multicolumn{2}{|l|}{4,000} & \multicolumn{2}{|l|}{4,000} & \multicolumn{2}{|l|}{4,000} & \multicolumn{2}{|l|}{4,000} & \\
\hline Batches/Day & & 1 & & 2 & & 2 & & 2 & & 2 & & 2 & & 2 & & 2 \\
\hline Days Operation $N$ Week & & 5 & & 5 & & 5 & & 5 & & 5 & & 6 & & 6 & & 7 \\
\hline Batches/Year & & 221 & & 208 & & 312 & & 442 & & 520 & & 530 & & 624 & & 619 \\
\hline Production Volume/week & & 17,000 & & 16,000 & & 24,000 & & 34,000 & & 40,000 & & 40,800 & & 48,000 & & 47,600 \\
\hline Production Volume/Year & & 884,000 & & 832,000 & & $1,248,000$ & & $1,768,000$ & & $2,080,000$ & & $2,121,600$ & & $2,496,000$ & & $2,475,200$ \\
\hline & & 18.4 & & 17.3 & & 26.0 & & 36.8 & & 43.3 & & 44.2 & & 52.0 & & 51.6 \\
\hline Feedstock Source & & & & & & & & & & & & & & & & \\
\hline Feedstock Required & & 930,526 & & 875,789 & & $1,313,684$ & & $1,861,053$ & & $2,189,474$ & & $2,233,263$ & & $2,627,368$ & & $2,605,474$ \\
\hline Back Haul Farmers & & 312,000 & & 312,000 & & 312,000 & & 312,000 & & 312,000 & & 312,000 & & 312,000 & & 312,000 \\
\hline from grease farming & & 216,484 & & 197,326 & & 350,589 & & 542,168 & & 657,116 & & 672,442 & & 810,379 & & 802,716 \\
\hline purchased & & 402,042 & & 366,463 & & 651,095 & & $1,006,884$ & & $1,220,358$ & & $1,248,821$ & & $1,504,989$ & & $1,490,758$ \\
\hline Cost/Gallon & & 0.676 & & 0.663 & & 0.739 & & 0.784 & & 0.800 & & 0.802 & & 0.815 & & 0.815 \\
\hline Raw Materials/Batch & & & & & & & & & & & & & & & & \\
\hline Oil (gallons) & & 4,211 & & 4,211 & & 4,211 & & 4,211 & & 4,211 & & 4,211 & & 4,211 & & 4,211 \\
\hline Cost of Goods Sold (per & $\mathrm{b}$ & tch) & & & & & & & & & & & & & & \\
\hline Oil & $\$$ & $2,848.04$ & $\$$ & $2,791.43$ & $\$$ & $3,112.18$ & $\$$ & $3,300.86$ & $\$$ & $3,368.78$ & $\$$ & $3,376.33$ & $\$$ & $3,432.93$ & $\$$ & $3,430.24$ \\
\hline Other Materials & $\$$ & $1,298.65$ & $\$$ & $1,298.65$ & $\$$ & $1,298.65$ & $\$$ & $1,298.65$ & $\$$ & $1,298.65$ & $\$$ & $1,298.65$ & $\$$ & $1,298.65$ & $\$$ & $1,298.65$ \\
\hline Labor Cost/Batch & $\$$ & 720.81 & $\$$ & 765.87 & $\$$ & 510.58 & $\$$ & 360.41 & $\$$ & 306.35 & $\$$ & 334.94 & $\$$ & 284.70 & $\$$ & 316.75 \\
\hline TOTAL COGS/Batch & $\$$ & $4,867.51$ & $\$$ & $4,855.95$ & $\$$ & $4,921.42$ & $\$$ & $4,959.92$ & $\$$ & $4,973.78$ & $\$$ & $5,009.93$ & $\$$ & $5,016.29$ & $\$$ & $5,045.64$ \\
\hline COGS/GALLON & $\$$ & 1.217 & $\$$ & 1.214 & $\$$ & 1.230 & $\$$ & 1.240 & $\$$ & 1.243 & $\$$ & 1.252 & $\$$ & 1.254 & $\$$ & 1.261 \\
\hline Fixed Bxpenses & & & & & & & & & & & & & & & & \\
\hline Management & $\$$ & 289,810 & $\$$ & 289,810 & $\$$ & 289,810 & $\$$ & 289,810 & $\$$ & 289,810 & $\$$ & 289,810 & $\$$ & 289,810 & $\$$ & 289,810 \\
\hline Sales & $\$$ & 80,250 & $\$$ & 80,250 & $\$$ & 80,250 & $\$$ & 80,250 & $\$$ & 80,250 & $\$$ & 80,250 & $\$$ & 80,250 & $\$$ & 80,250 \\
\hline Interest expense - year 1 & $\$$ & 89,804 & $\$$ & 89,804 & $\$$ & 89,804 & $\$$ & 89,804 & $\$$ & 89,804 & $\$$ & 89,804 & $\$$ & 89,804 & $\$$ & 89,804 \\
\hline Depreciation - 15 yr s $/$ & $\$$ & 197,623 & $\$$ & 197,623 & $\$$ & 197,623 & $\$$ & 197,623 & $\$$ & 197,623 & $\$$ & 197,623 & $\$$ & 197,623 & $\$$ & 197,623 \\
\hline Total Fixed Costs & $\$$ & 657,488 & $\$$ & 657,488 & $\$$ & 657,488 & $\$$ & 657,488 & $\$$ & 657,488 & $\$$ & 657,488 & $\$$ & 657,488 & $\$$ & 657,488 \\
\hline Total Production & & & & & & & & & & & & & & & & \\
\hline Costs/Gallon aka & & & & & & & & & & & & & & & & \\
\hline Breakeven Price/Gallon & $\$$ & 1.961 & $\$$ & 2.004 & $\$$ & 1.757 & $\$$ & 1.612 & $\$$ & 1.560 & $\$$ & 1.562 & $\$$ & 1.517 & $\$$ & 1.527 \\
\hline RATIOS & & & & & & & & & & & & & & & & \\
\hline Operating Capacity & & $44 \%$ & & $42 \%$ & & $62 \%$ & & $88 \%$ & & $104 \%$ & & $106 \%$ & & $125 \%$ & & $124 \%$ \\
\hline Total fixed costs per batch & & 2,975 & & 3,161 & & 2,107 & & 1,488 & & 1,264 & & 1,240 & & 1,054 & & 1,063 \\
\hline Total production costs per batc & & 4,868 & & 4,856 & & 4,921 & & 4,960 & & 4,974 & & 5,010 & & 5,016 & & 5,046 \\
\hline Total costs per batch & & 7,843 & & 8,017 & & 7,029 & & 6,447 & & 6,238 & & 6,250 & & 6,070 & & 6,108 \\
\hline Breakeven price/gallon & $\overline{\$ \$ \$}$ & 1.961 & 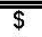 & 2.004 & 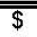 & 1.757 & 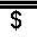 & 1.612 & 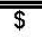 & 1.560 & $\overline{\$ \$ \$}$ & 1.562 & $\overline{\$ \$}$ & 1.517 & 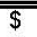 & 1.527 \\
\hline Feedcost cost per gal & $\$$ & 0.676 & $\$$ & 0.663 & $\$$ & 0.739 & $\$$ & 0.784 & $\$$ & 0.800 & $\$$ & 0.802 & $\$$ & 0.815 & $\$$ & 0.815 \\
\hline Fixed cost per gal & $\$$ & 0.744 & $\$$ & 0.790 & $\$$ & 0.527 & $\$$ & 0.372 & $\$$ & 0.316 & $\$$ & 0.310 & $\$$ & 0.263 & $\$$ & 0.266 \\
\hline Non feedstock COGS & $\$$ & 0.540 & $\$$ & 0.551 & $\$$ & 0.491 & $\$$ & 0.456 & $\$$ & 0.443 & $\$$ & 0.451 & $\$$ & 0.439 & $\$$ & 0.447 \\
\hline Total nonfeedstock cost/gal & $\$$ & 1.284 & $\$$ & 1.341 & $\$$ & 1.018 & $\$$ & 0.828 & $\$$ & 0.759 & $\$$ & 0.761 & $\$$ & 0.702 & $\$$ & 0.712 \\
\hline BREAK-EVEN & & & & & & & & & & & & & & & & \\
\hline if targetted Gross Margin is & & $40 \%$ & & & & & & & & & & & & & & \\
\hline Break-even sales are & $\$$ & $1,643,720$ & $\$$ & $1,643,720$ & $\$$ & $1,643,720$ & $\$$ & $1,643,720$ & $\$$ & $1,643,720$ & $\$$ & $1,643,720$ & $\$$ & $1,643,720$ & $\$$ & $1,643,720$ \\
\hline Price/Gallon produced must be & $\$$ & 3.076 & $\$$ & 3.190 & $\$$ & 2.547 & $\$$ & 2.170 & $\$$ & 2.034 & $\$$ & 2.027 & $\$$ & 1.913 & $\$$ & 1.925 \\
\hline at Targetted Price & $\$$ & 3.24 & $\$$ & 3.31 & $\$$ & 2.90 & $\$$ & 2.66 & $\$$ & 2.57 & $\$$ & 2.58 & $\$$ & 2.50 & $\$$ & 2.52 \\
\hline Break-even Volume & & 159,476 & & 152,613 & & 198,543 & & 235,958 & & 252,054 & & 251,140 & & 266,219 & & 262,899 \\
\hline at Fixed Price & $\$$ & 2.10 & $\$$ & 2.10 & $\$$ & 2.10 & $\$$ & 2.10 & $\$$ & 2.10 & $\$$ & 2.10 & $\$$ & 2.10 & $\$$ & 2.10 \\
\hline Break-even Volume & & $2,246,645$ & & $3,269,474$ & & 913,296 & & 641,397 & & 579,309 & & 582,366 & & 537,483 & & 546,444 \\
\hline
\end{tabular}


Appendix 2: Summary Profit and Loss Statement

\begin{tabular}{|c|c|c|c|c|c|c|c|c|c|}
\hline & 2005 & & 2006 & & 2007 & & 2008 & & 2009 \\
\hline rease Farm Oil Delivered (gallons & 57,400 & & 340,000 & & 399,000 & & $1,052,400$ & & $1,052,400$ \\
\hline Purchased Oil (gallons) & - & & $3,080,000$ & & $8,930,000$ & & $8,250,000$ & & $8,225,000$ \\
\hline Batches Made & - & & 820 & & 2,210 & & 2,210 & & 2,210 \\
\hline Feedstock Gallons Used & - & & $3,452,632$ & & $9,305,263$ & & $9,305,263$ & & $9,305,263$ \\
\hline Gallons Produced & - & & $3,280,000$ & & $8,840,000$ & & $8,840,000$ & & $8,840,000$ \\
\hline Gal. Sold & - & & $2,514,600$ & & $8,751,600$ & & $8,751,600$ & & $8,751,600$ \\
\hline Gal Used Internally & - & & 32,800 & & 88,400 & & 88,400 & & 88,400 \\
\hline Income statement & 2005 & & 2006 & & 2007 & & 2008 & & 2009 \\
\hline \multicolumn{10}{|l|}{ REVENOES } \\
\hline Wholesale SALES & - & 08 & $5,016,627$ & 948 & $17,459,442$ & 948 & $17,459,442$ & $94 \%$ & $17,459,442$ \\
\hline Retail SALES & - & $0 \%$ & 352,547 & 78 & $1,226,974$ & 78 & $1,226,974$ & 78 & $1,226,974$ \\
\hline USDA Credit & - & $0 \%$ & - & $0 \%$ & - & $0 \%$ & - & 0.08 & - \\
\hline Membership Fees & - & $0 \%$ & - & $0 \%$ & - & $0 \%$ & - & 0.08 & - \\
\hline By-product Income & - & 08 & $(29,848)$ & -18 & $(80,444)$ & $0 \%$ & $(80,444)$ & -0.48 & $(80,444)$ \\
\hline TOTAL INCOME & 0 & 08 & $5,339,326$ & 1008 & $18,605,972$ & 1008 & $18,605,972$ & $100 \%$ & $18,605,972$ \\
\hline
\end{tabular}

\section{EXPENSES}

COST OF GOODS SOLD (COGS)

\begin{tabular}{|c|c|c|c|c|c|c|c|c|c|}
\hline Feedstock & 14,700 & $0 \%$ & $3,813,680$ & $71 \%$ & $10,909,880$ & 598 & $10,283,100$ & $55 \%$ & $10,252,850$ \\
\hline Other Materials (includes Transp & - & $0 \%$ & $1,064,896$ & 208 & $2,956,126$ & 168 & $3,044,810$ & 168 & $3,136,154$ \\
\hline Labor & 79,650 & $0 \%$ & 164,079 & 38 & 169,001 & 18 & 174,071 & $1 \%$ & 179,294 \\
\hline Extra Day Labor & 4,585 & $0 \%$ & 18,339 & $0 \%$ & 18,339 & & 18,339 & $0 \%$ & 18,339 \\
\hline Fuel Taxes & - & $0 \%$ & 57,081 & 18 & 198,661 & $1 \%$ & 198,661 & 18 & 198,661 \\
\hline Sub-Total COGS & 98,935 & $0 \%$ & $5,118,076$ & $96 \%$ & $14,252,008$ & $77 \%$ & $13,718,982$ & $74 \frac{\circ}{8}$ & $13,785,298$ \\
\hline GROSS PROFIT & $(98,935)$ & $0 \%$ & 221,250 & $4 \%$ & $4,353,964$ & $23 \%$ & $4,886,991$ & $26 \%$ & $4,820,674$ \\
\hline \multicolumn{10}{|l|}{ Selling, General \& Admin Expenses } \\
\hline Management Expenses & 249,905 & $0 \%$ & 289,810 & $5 \%$ & 298,505 & $2 \%$ & 307,460 & 28 & 316,684 \\
\hline Depreciation Expense & 98,812 & $0 \%$ & 286,512 & 58 & 730,957 & 48 & 730,957 & 48 & 730,957 \\
\hline Sales Expenses & 56,125 & $0 \%$ & 92,190 & $2 \%$ & 137,910 & $1 \%$ & 133,895 & $1 \%$ & 131,449 \\
\hline Sub-total $S, G \& A$ EXPENSES & 404,842 & 08 & 668,512 & $13 \%$ & $1,167,371$ & 68 & $1,172,312$ & 68 & $1,179,090$ \\
\hline Taxes & - & $0 \%$ & - & 08 & $(37,587)$ & $0 \%$ & 136,834 & 18 & 144,034 \\
\hline Interest Expense & 30,113 & $0 \%$ & 304,474 & $6 \%$ & 558,922 & 38 & 437,175 & 28 & 367,182 \\
\hline TOTAL EXPENSES & 533,890 & 08 & $6,091,062$ & $114 \%$ & $15,940,714$ & 868 & $15,465,302$ & $83 \%$ & $15,475,604$ \\
\hline NET PROFIT (LOSS) & $(533,890)$ & 08 & $(751,736)$ & -148 & $2,665,258$ & 148 & $3,140,671$ & $17 \%$ & $3,130,368$ \\
\hline Disbursed as Profit Sharing & - & & - & & $(71,415)$ & & 259,984 & & 273,665 \\
\hline Class "B" Equity Holders Dividends & - & & - & & - & & 376,250 & & 376,250 \\
\hline Retained Eamings & $(533,890)$ & & $(751,736)$ & & $2,736,673$ & & $2,504,437$ & & $2,480,453$ \\
\hline Total CASH Receipts & - & & $3,781,812$ & & $18,605,972$ & & $18,605,972$ & & $18,605,972$ \\
\hline Total Operating Disbursements & 430,267 & & $5,441,193$ & & $14,627,996$ & & $14,098,097$ & & $14,169,324$ \\
\hline Net Operating Cash & $(430,267)$ & & $(1,659,380)$ & & $3,977,977$ & & $4,507,875$ & & $4,436,648$ \\
\hline Annual Loan Payments (w/o LOC) & 43,229 & & 660,096 & & $1,230,210$ & & $1,230,210$ & & $1,230,210$ \\
\hline
\end{tabular}

RATIOS

Gross Margin

Net Margin

Debt to Equity

$0 \%$
$0 \%$
$49 \%$
-
-
$-2.95)$
$-41.7 \%$

$4 \%$
$-14 \%$
$248 \%$

0.43
$(2.51)$
$-29 \%$
$-19.7 \%$
$\$ 4,748,093$
$28.24 \%$

$23 \%$
$14 \%$
$105 \%$

0.87
3.23
$60 \%$
$35.1 \%$

$26 \%$

$17 \%$

$61 \%$

$26 \%$

Asset Tumover Ratio (net of credit \& fees)

Debt Coverage Ratio

Retum on Invested Capital (if paid)

Retum on Ave. Equity

NPV of cash flow 2005-2009 (20\% rate)

Total Retum on Ave. Equity '05 - '09

$28.24 \%$

$\begin{array}{rr}0.80 & 0.70 \\ 3.66 & 3.61 \\ 55 \% & 54 \% \\ 19.2 \% & 13.8 \%\end{array}$


Appendix 2: Balance Sheet

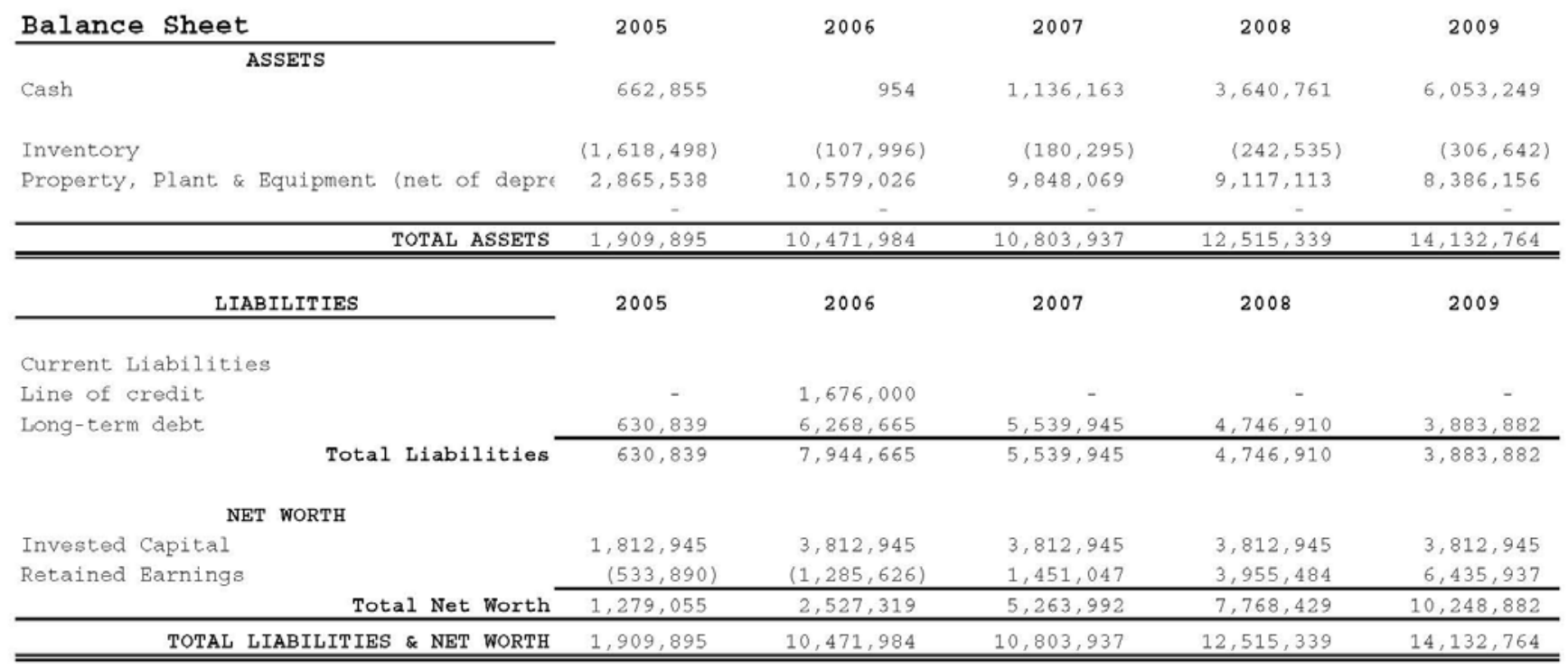




\section{Attachment 3: Population of New England, New York, New Jersey, Pennsylvania}

$\begin{array}{lr}\text { State } & \text { Population } \\ & \\ \text { Connecticut } & 3,483,372 \\ \text { Massachusetts } & 6,433,422 \\ \text { New York } & 10,190,115 \\ \text { New Hampshire } & 1,287,687 \\ \text { Vermont } & 619,107 \\ \text { Maine } & 1,305,728 \\ \text { Rhode Island } & 1,076,164 \\ \text { Pennsylvania } & 12,365,455 \\ \text { New Jersey } & 8,638,396 \\ & \\ \text { Total } & 54,399,446\end{array}$

RVO produced per person: $1.1 \mathrm{gal} / \mathrm{yr}$

RVO produced in the Northeast: $59,839,391 \mathrm{gal} / \mathrm{yr}$ 


\section{Attachment 4: Recycled Vegetable Oil Resources (Restaurants and Cafeterias Within a 60-Mile Radius of Greenfield, Massachusetts)}

Food (5,936 listings)

- American restaurants (58)

- Bar and grill restaurants (68)

- Bars and pubs (126)

- Chinese restaurants (244)

- Family restaurants (86)

- Fast food restaurants (323)

- Fast foods and carry-out (41)

- Fine dining restaurants (39)

- Italian restaurants (89)

Schools with cafeterias (2,302 listings)

- Child care centers (102)

- Colleges and universities (1023)

- Elementary and secondary education (238)

- Elementary schools (349)

- High schools (3)

- Preschools and kindergartens (265)

- Private schools (11)

- Schools (124)

- Business colleges (5)

- Business education (69)

- College preparatory schools (1)
- Japanese restaurants (23)

- Mexican restaurants (29)

- Pizza restaurants (946)

- Pubs (10)

- Restaurants (3767)

- Seafood restaurants (49)

- Sports bars (16)

- Steak and barbecue restaurants (21)

- Steak and seafood restaurants (1)

- Culinary schools (5)

- Engineering schools (2)

- Graduate and professional schools (3)

- Industrial and trade schools (2)

- Law schools (2)

- Medical laboratory schools (2)

- Medical schools (1)

- Montessori schools (2)

- Schools for the deaf (29)

- Vocational education (31) 


\title{
Attachment 5: Plant Job Descriptions
}

\section{The Biodiesel Production Facility \\ President and CEO Job Description}

\author{
Job Title: $\quad$ President and CEO \\ Reports To: $\quad$ Board of Directors \\ FLSA Status: Exempt \\ Prepared By: Lynn Benander \\ Prepared Date: $\quad$ August 16, 2004 \\ Approved By: $\quad$ Board of Directors \\ Approved Date: $\quad$ October 29, 2004
}

\section{SUMMARY}

Directs and coordinates activities of biodiesel production facility to obtain optimum efficiency and profitability by performing the following duties personally or through subordinate employees.

ESSENTIAL DUTIES AND RESPONSIBILITIES include the following. Other duties may be assigned.

Plans, develops, and implements organization policies and goals within policies established by the Board of Directors.

Coordinates activities such as operating, manufacturing, engineering, planning, sales, maintenance, or research and development to effect operational efficiency and economy.

Secures recycled vegetable oil.

Directs and coordinates promotion of products manufactured or services performed to develop new markets, increase share of market, and obtain competitive position in industry. Sells annual plant output.

Oversees and directs treasury, budgeting, audit, tax, accounting, purchasing, real estate, long-range forecasting, and insurance activities for the organization. Ensures adequate accounting controls are in place.

Appraises the organization's financial position and issues periodic reports on organization's financial stability, liquidity, and growth.

Analyzes operational issues affecting the company and determines their financial impact.

Confers with administrative personnel and reviews activity, operating, and sales reports to determine changes in programs or operations required.

Confers with technical personnel and reviews activity, operating, and quality control reports to determine changes in programs or operations required.

Directs preparation of directives outlining policy, program, or operations changes to be implemented. 
Promotes organization in the community and in industry, with regulatory bodies, and in manufacturing or trade associations.

\section{SUPERVISORY RESPONSIBILITIES}

At launch, the General Manager will supervise the VP of Finance and Operations and the Administrative Assistant.

\section{QUALIFICATIONS}

To perform this job successfully, an individual must be able to perform each essential duty satisfactorily. The requirements listed below are representative of the knowledge, skill, and/or ability required. Reasonable accommodations may be made to enable individuals with disabilities to perform the essential functions.

\section{EDUCATION and/or EXPERIENCE}

REQUIRED: Business degree and 3 years management experience or 10 years management experience with full profit and loss responsibility for more than $\$ 2$ million in annual sales

PREFERRED: MBA; start-up or turn-around experience; experience in wholesale and retail marketing and sales; experience in manufacturing management; experience with biodiesel production technology or chemical processing; engineering degree; participatory management experience. 


\title{
The Biodiesel Production Facility Vice President of Finance and Operations Job Description
}

\author{
Job Title: $\quad$ Vice President of Finance and Operations \\ Reports To: $\quad$ President and CEO \\ FLSA Status: Exempt \\ Prepared By: Lynn Benander \\ Prepared Date: $\quad$ February 21, 2005
}

\section{SUMMARY}

Directs and coordinates technical activities of biodiesel production facility to obtain optimum

efficiency and economy of operations, produce high quality fuel, and maximize profits; and directs the organization's financial planning and accounting practices as well as its relationship with lending institutions and shareholders by performing the following duties personally or through subordinate managers.

ESSENTIAL DUTIES AND RESPONSIBILITIES include the following. Other duties may be assigned.

Coordinates activities such as operating, manufacturing, engineering, planning, maintenance, and research and development, to effect operational efficiency and economy.

Directs activities of engineering personnel engaged in preparing plans, designs, cost estimates, and specifications for production facility to determine most feasible approach to biodiesel production.

Oversees fabricating, installing, and modifying equipment to ensure that critical standards are met. Oversees biodiesel production processes and makes modifications or changes. Ensures biodiesel processing equipment is well-maintained. Oversees workers engaged in constructing, operating, controlling, and improving equipment to carry out biodiesel production. Oversees equipment to control movement, storage, and packaging of products and by-products.

Analyzes operating procedures and equipment and machinery functions to increase product quality and reduce processing time and cost.

Oversees quality control program and practices. Designs and plans measurement and control systems for production process based on data collected in laboratory experiments, pilot plant operations, and process evaluations. Applies principles of chemical engineering to produce high-quality biodiesel.

Ensures safety protocols are implemented and that workers are trained in safety practices.

Ensures plant meets all regulatory requirements.

Determines most effective arrangement of operations, exercising judgment to compromise among process requirements, economic evaluation, operator effectiveness, and physical and health hazards. Confers with the President and reviews activity, operating, and product quality reports to determine changes in operations required. Analyzes, consolidates, and directs all cost accounting procedures together with other statistical and routine reports.

Oversees and directs treasury, budgeting, audit, tax, accounting, purchasing, real estate, long-range forecasting, and insurance activities for the organization. 
Oversees procedures and computer application systems necessary to maintain proper records and afford adequate accounting controls and services.

Appraises the organization's financial position and issues periodic reports on organization's financial stability, liquidity, and growth.

Coordinates tax reporting programs and investor relations activities.

Oversees and directs the preparation and issuance of the corporation's annual report.

Directs and analyzes studies of general economic, business, and financial conditions and their impact on the organization's policies and operations.

Evaluates and recommends business partnering opportunities.

Establishes and maintains contacts with stockholders and financial institutions.

\section{SUPERVISORY RESPONSIBILITIES}

At launch, the VP of Finance and Operations will supervise the Quality Control Manager, Production Assistant, and Receiving Assistant.

\section{QUALIFICATIONS}

To perform this job successfully, an individual must be able to perform each essential duty satisfactorily. The requirements listed below are representative of the knowledge, skill, and/or ability required. Reasonable accommodations may be made to enable individuals with disabilities to perform the essential functions.

\section{EDUCATION and/or EXPERIENCE}

REQUIRED: MBA or finance degree; Engineering degree and 3 years chemical manufacturing management experience or 6 years chemical manufacturing management experience; supervisory experience

PREFERRED: Start-up manufacturing plant management experience; experience with biodiesel production technology; business or engineering degree; participatory management experience. 


\title{
The Biodiesel Production Facility Production and Quality Technician Job Description
}

\author{
Job Title: $\quad$ Production and Quality Technician \\ Reports To: $\quad$ VP of Finance and Operations \\ FLSA Status: Exempt \\ Prepared By: Lynn Benander \\ Prepared Date: February 21, 2005
}

\section{SUMMARY}

Produces quality biodiesel, tests and inspects biodiesel at various stages of production, and compiles and evaluates statistical data to determine and maintain quality of biodiesel by performing the following duties.

ESSENTIAL DUTIES AND RESPONSIBILITIES include the following. Other duties may be assigned.

Supports activities of engineering personnel engaged in preparing plans, designs, cost estimates, and specifications for production facility to determine most feasible approach to biodiesel production.

Prepares charts, sketches, diagrams, and flow charts and compiles and records engineering data to clarify design details or functional criteria of chemical processing and physical operation units.

Participates in fabricating, installing, and modifying equipment to ensure that critical standards are met.

Tests equipment and formulates standard operating procedures.

Operates biodiesel production processes and makes modifications or changes.

Performs preventive and corrective maintenance of biodiesel processing equipment.

Designs, plans layout, and oversees workers engaged in constructing, operating, controlling, and improving equipment to carry out biodiesel production.

Analyzes operating procedures and equipment and machinery functions to increase product quality and reduce processing time and cost.

Designs equipment to control movement, storage, and packaging of feedstocks, biodiesel, and byproducts.

Interprets engineering drawings, schematic diagrams, or formulas and confers with management to determine quality and reliability standards.

Selects products for tests at specified stages in production process and tests products for chemical characteristics.

Records test data, applying statistical quality control procedures.

Evaluates data and writes reports to validate or indicate deviations from existing standards. 
Recommends modifications of existing quality or production standards to achieve optimum quality within limits of equipment capability.

Prepares graphs or charts of data or enters data into computer for analysis.

Designs and plans measurement and control systems for production process based on data collected in laboratory experiments, plant operations, and process evaluations.

Applies principles of chemical engineering to produce high-quality biodiesel.

Designs and implements safety protocols; trains workers in safety practices.

Ensures plant meets all regulatory requirements.

Determines most effective arrangement of unit operations exercising judgment to compromise among process requirements, economic evaluation, operator effectiveness, and physical and health hazards.

Confers with management personnel and reviews activity, operating, and product quality reports to determine changes in operations required.

\section{SUPERVISORY RESPONSIBILITIES}

None

\section{QUALIFICATIONS}

To perform this job successfully, an individual must be able to perform each essential duty satisfactorily. The requirements listed below are representative of the knowledge, skill, and/or ability required. Reasonable accommodations may be made to enable individuals with disabilities to perform the essential functions.

\section{EDUCATION and/or EXPERIENCE}

REQUIRED: 3 years chemical manufacturing experience or 3 years manufacturing quality control experience

PREFERRED: Chemical engineering degree; experience with biodiesel production technology 


\section{Attachment 6: Regulatory Requirements}

\section{U.S. Department of Transportation}

- $\quad$ Oil Spill Prevention Plan 40 CFR 130

- Communication Requirement 40 CFR 130.11

- Containers 40 CFR 130.21

○ Written Response Plan 40 CFR 130.31

\section{U.S. Department of Environmental Protection}

- Oil Spill Prevention and Countermeasures Plan 40 CFR 112

- Risk Management Plan

- Clean Air Act Section 112(r): Prevention of Accidental Releases

\section{Massachusetts Department of Environmental Protection}

- Ambient Air Quality 310 CMR 6.00

- Particulate matter standards

- NOx standards

- Air Pollution Control 310 CMR 7.00

- Vegetable oil and glycerin burner

○ RVO storage tanks

- Methanol storage tank

○ Dispensing Motor Vehicle Fuel 310 CMR 7.24(6)

- Wetland Protection 310 CMR 10.00

○ Wetlands delineation

○ Wetlands mapping

- Hazardous Waste Regulations 310 CMR 30.00

- Hazardous waste management plan

- Massachusetts Contingency Plan 310 CMR 40.00 


\section{Massachusetts Board of Fire Prevention 527 CMR 14.00}

- Flammable Liquids, etc.

- Class IIIC liquid with flash point $>300^{\circ} \mathrm{F}$

- Laboratory documentation

- Storage tank requirements

- $\quad$ Tank Storage Chapter 148 Section 37

- Fire marshal permit for storage

\section{Town of Greenfield}

- Solid waste disposal permit

- Greenfield Fire Marshal

- National Fire Protection Association Code 30 Flammable and Combustible Liquids

- See Summary in Feasibility Study

- Alarms systems permit

○ Chimney installation

\section{Greenfield Wastewater Treatment Plant}

- Sewer service

- $\mathrm{BOD}_{5}$ testing

- Grease trap plan

\section{Internal Revenue Service}

- F.I.D.

- Excise tax form 720

$\circ$ Quarterly filing and payment 


\section{Massachusetts Department of Revenue}

- Special Fuels Producer License

- Annual renewal

- Supplier’s Tax Return - Special Fuels

$\circ$ Monthly filing and payment

\section{Occupational Safety and Health Administration}

- Confined Space 29 CFR 1910.146

$\circ$ Labeling and signage

- Permits for confined space entry

○ Written procedures

- Rescue plan

- Access plan

- Training

- Safety equipment

- Four gas meter

- Rescue harness

- Rescue winch

- Ventilation system

- Personal protection

- Hazard Communication 29 CFR 1910.1200

○ Right-to-know requirements

- Material safety data sheet for each chemical

- Container labeling

- Employee training

- Chemical handling procedures

- Personal protective equipment

- First aid systems

- Emergency response plans

$\circ$ Pipe labeling

- Respiratory Protection 29 CFR 1910.134

- Medical certification

o Fit testing

- Respiratory maintenance

- Cartridge selection 
- Electrical Safety 29 CFR 1910 Subpart S

○ Lock Out/Tag Out 29 CFR 1910.147

- Equipment

- Training

- Written program

○ National Electrical Code

- Emergency disconnects

- Ground fault protection

- Egress/Fire Protection 29 CFR 1910 Subpart E \& L

$\circ$ Emergency Egress

- Aisles and signage

- Emergency Action Plan 29 CFR 1910.38A

- Training

- Fire Protection 29 CFR 1910.38B

- Fire extinguishers

- Training

- Response team

- Alarm systems

- Personal Protective Equipment 29 CFR 1900.132

- Steel-toed shoes or boots

- Gloves: nitrile or latex

- Hard hats: required for bump hazard

- Eye protection: splash goggles

- Protective clothing: aprons

- Walking and Working Surfaces 29 CFR 1910 Subpart D

○ Non-slip surfaces

- Safety rails for tanks

- Orderly and clean surfaces

- Floor openings

- Portable ladders

- Fixed ladders

- Fall protection system

- Exposure to Hazardous Chemicals 29 CFR 1910.1000

- Community Right to Know Law

- Hazardous Waste Regulations 
- Industrial Trucks 29 CFR 1910.178

- Training

- Curbs

- Occupational Noise Exposure 29 CFR 1910.95

- $85 \mathrm{db}$ maximum

$\circ$ Noise $(\mathrm{db})$ meter

- Other Requirements

- Ergonomics

○ Record keeping

- Posters, notices 
Appendix C: Study of Cogeneration Feasibility for Northeast Biodiesel LLC 


\section{List of Acronyms}

$\begin{array}{ll}\text { BACT } & \text { best available control technology } \\ \text { CHP } & \text { combined heat and power } \\ \text { DEP } & \text { Department of Environmental Protection } \\ \text { DOER } & \text { Division of Energy Resources } \\ \text { GIS } & \text { generation information system } \\ \text { IEEE } & \text { Institute of Electrical and Electronics Engineers } \\ \text { IV } & \text { iodine value } \\ \text { NOLS } & \text { National Outdoor Leadership School } \\ \text { PAH } & \text { polycyclic aromatic hydrocarbon } \\ \text { REC } & \text { renewable energy certificate } \\ \text { RME } & \text { rape methyl ester } \\ \text { RPS } & \text { renewable portfolio standard } \\ \text { SVO } & \text { straight vegetable oil } \\ \text { WVO } & \text { waste vegetable oil }\end{array}$




\section{Executive Summary}

The concept of in-plant cogeneration (producing electricity plus heat) at the proposed Northeast Biodiesel production facility is appealing because cogeneration saves energy and money and, in this case, would use a renewable fuel: waste vegetable oil (WVO) feedstock, which is also the raw material for biodiesel production. In this case, under the auspices of the Massachusetts Renewable Portfolio Standard (RPS), there is also an opportunity to provide renewable electrical power to the grid.

The study examines the burning of straight vegetable oil (SVO) as well as biodiesel in a modified diesel engine generator system. The use of SVO, although still somewhat experimental, has been widely tried in both research and industrial settings. The use of biodiesel is widely established. However, very few examples of using either fuel in a stationary engine application exist.

The diesel engine was originally designed by Rudolph Diesel to operate on vegetable oil fuel; however, the discovery and subsequent wide availability of petroleum fuel soon thereafter resulted in an almost complete shift away from vegetable-derived fuels. Engine and fuel system development since that time has focused almost exclusively on petrodiesel. Although there was some interest in returning to SVO fuel during World War II, both SVO and biodiesel re-emerged as diesel engine fuels only within the past 10 years because of interest in global warming and other eco-political concerns. The internet has played an important role in publicizing research, sharing technical know-how and experiences, and generally accelerating the use of biodiesel and SVO.

The key issues involved in the examination of cogeneration feasibility are technical-, financial-, regulatory-, and feedstock source-related. This study considers how this business function fits into the primary business enterprise of Northeast Biodiesel.

It is assumed that provisions for cogeneration will be installed during plant construction; however, actual the installation of cogeneration equipment and its operation is not expected to occur until the plant is fully operational at its target capacity of 10 million gallons per year (2007 or 2008).

\section{Technical Analysis}

This study does not review the technical aspects of burning biodiesel fuel in diesel engines. Such research is extensive and widely available. However, SVO fuel has not undergone the extensive testing that biodiesel fuel has, it has not been as thoroughly researched, and its actual use in engines is much less widespread. Therefore, this study reviews existing research on the use of SVO fuel in diesel engines.

This experience indicates that SVO fuel lends itself to stationary engine application. As a new system, the engine can be optimized - particularly regarding the fuel injection system —in ways that will enhance its performance based on the experience of others burning SVO during the past 15 years. 


\section{Financial Analysis}

Financially, the economics of all independent "power plants" below multi-megawatt utility size generally have two hurdles:

1. The system must be sized at the average power usage of the plant because selling the power is often not worthwhile. (The utility price is too low.)

2. The system's waste thermal energy must have value (i.e., be used in the plant). The value of the thermal energy is key to making an in-plant power project economically attractive.

The Massachusetts RPS, created by the state legislature in 1997 and in effect since 2003, has modified this paradigm. The RPS allows renewable power generators to sell power to the grid at a price that makes smaller systems more feasible than in the past.

Right now, electricity made from renewable sources is in demand in Massachusetts; Renewable energy certificate (REC) values are at an all-time high, with 5-year contracts available from wholesalers. In addition, in support of the nascent renewable energy industry in Massachusetts, the Massachusetts Renewable Energy Trust's Green Power Program will cover the remaining investment life of renewable power projects by taking on the 5-15 year long-term price risk. In light of issues such as rising petroleum prices and concerns about dependence on foreign oil, this is a particularly advantageous time to consider producing renewable power for sale to the grid.

\section{Emissions}

Emissions profiles of biodiesel engines are well established through extensive Environmental Protection Agency testing. However, determining the emissions from SVO- and WVO-fired engines is a work in progress. The undisputed advantages of SVO fuel lie in its sulfur-free emissions and reduced greenhouse gases (versus petrodiesel). However, studies completed domestically and internationally over the past 15 years indicate a wide variation in other emissions, both regulated and unregulated, that depends on fuel type, fuel pretreatment, engine type, operating cycle, and ambient temperature.

\section{Permitting}

Permitting to operate in Massachusetts includes two main elements: compliance with Department of Environmental Protection (DEP) emissions regulations and compliance with the RPS to sell RECs. Conversations with the Division of Energy Resources (DOER) indicate that an advisory ruling must be obtained from DOER that designates WVO as an accepted renewable fuel under the RPS. (Indications are that this should be fairly straightforward.) New DEP regulations likely to be in effect by the time this system is installed would require that the system comply with specific emissions limits for nitrogen oxide, particulate matter, carbon monoxide, and carbon dioxide. Depending on the DEP's determination, BACT (best available control technology) may be prescribed in addition to a program of monitoring and testing. 


\section{Feedstock Issues}

Survey and other data from the Northeast Biodiesel Feasibility Study and Business Plan indicate a potential capacity of 1-2 million gallons per year of WVO in the Western Massachusetts region (within about a 1-hour drive from the plant). However, Northeast Biodiesel is also considering buying feedstock from further afield. No collection system has yet been developed, so hard data are not available. The actual capacity available for collection remains to be seen and will be one of the key tasks of the new business. Purchasing WVO from area renderers is a last-choice option because of cost. Commodity WVO price has been volatile over the past several years because of a number of issues, and such volatility is likely to continue and be exacerbated by its new value as biodiesel feedstock in an emerging industry.

\section{Results}

The included financial projections show that the installation of a biodiesel- or WVO-fired power plant is an attractive option. However, if the waste engine heat is not used, regardless of the fuel, such a system is not feasible. The most critical factor is fuel availability of vegetable oil feedstock.

The financial and strategic value of the WVO is a key issue. The WVO has not only an absolute cost (its cost of collection) but also a lost opportunity cost because the material is also the feedstock for the plant's primary function, biodiesel production. The nature of REC contracts dictates long-term power availability at specified levels. This may not allow the plant the flexibility it may need in allocating WVO to production versus power generation as management simultaneously works to build markets and develop a collection system. 
C-vi 


\section{Table of Contents}

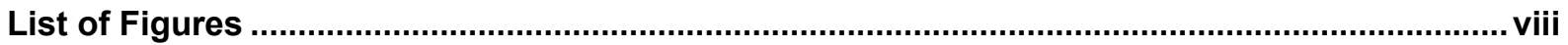

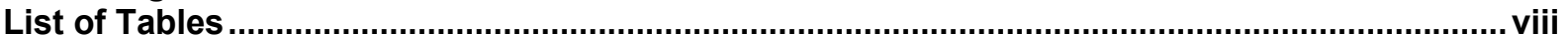

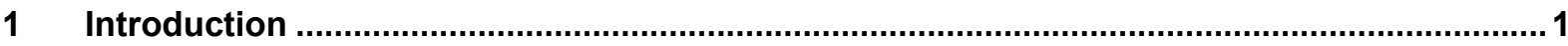

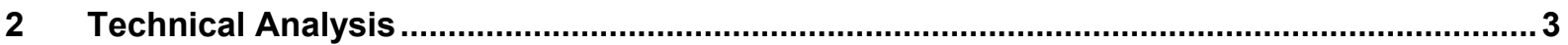

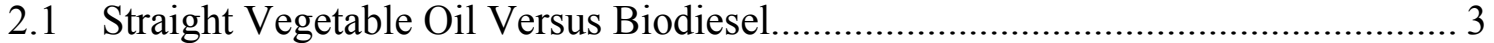

2.2 Why Straight Vegetable Oil? ............................................................................ 3

2.3 Burning Vegetable Oil in a Diesel Engine: Performance ..................................... 8

2.4 Burning Vegetable Oil in a Diesel Engine: Emissions ....................................... 9

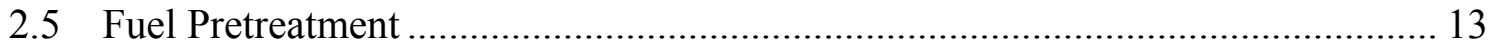

2.6 Engine Design and Duty Cycle Optimization for Straight Vegetable Oil Fuel .... 14

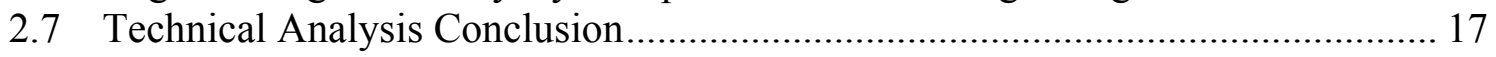

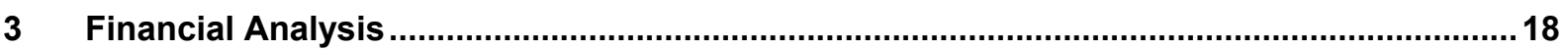

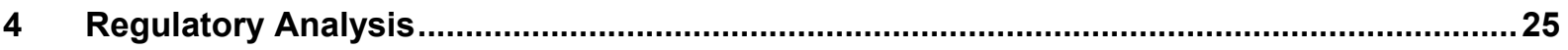

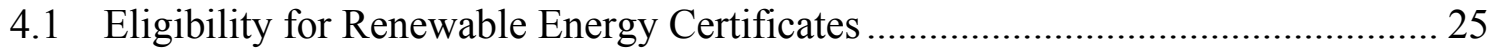

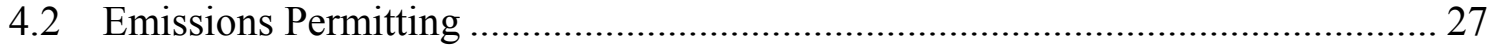

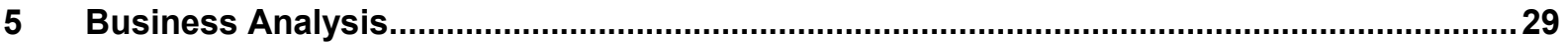

5.1 Effects on Base Business Resources ................................................................. 29

5.2 Effects on Core Business - Strategic Risks ...................................................... 29

5.3 Replicability: Biodiesel- and Straight Vegetable Oil-Fueled Distributed

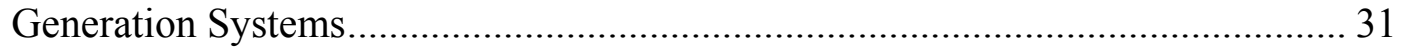

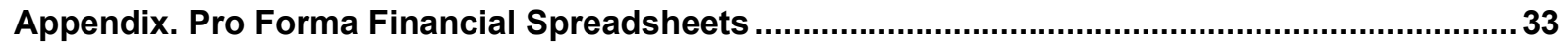




\section{List of Figures}

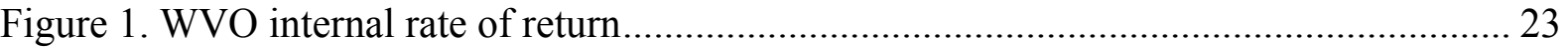

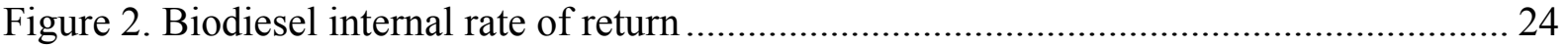

\section{List of Tables}

Table 1. Biodiesel Plant Utility Consumption ................................................................... 19

Table 2. Contribution to Thermal Load by Cogeneration System .......................................... 24

Table 3. Cogeneration System Fuel Requirements .......................................................... 30

Table A-1. Capital Costs for Cogeneration System ........................................................ 34

Table A-2. Biodiesel Facility Biodiesel Cogeneration ….................................................. 35

Table A-3. Biodiesel Facility Biodiesel Cogeneration Income Statement ............................ 37

Table A-4. Biodiesel Facility Straight Vegetable Oil Cogeneration..................................... 39

Table A-5. Biodiesel Facility Straight Vegetable Oil Cogeneration Income Statement......... 41 


\section{Introduction}

In recent years, many environmentally conscious motorists who feel strongly about avoiding petroleum fuels have obtained diesel vehicles and purchased biodiesel or biodiesel blends (usually going out of their way to do so). The most venturesome have converted their diesel vehicles to accommodate straight vegetable oil (SVO) by purchasing kits available over the Internet from domestic and international companies. These "green weenies" have created a mini-industry for conversion kit producers such as Neoteric Biofuels of California and Greasecar.com (in Florence, Massachusetts). SVO users obtain their own fuel (usually waste oil from restaurants) themselves, and the savings are a major incentive.

The use of SVO as diesel engine fuel is well established historically. Rudolph Diesel's innovative engine burned peanut oil when it was shown at the Paris Exhibition in 1900. In response to concerns about pollution, global warming, and dependency on foreign petroleum, the use of SVO in diesel engines has grown significantly world-wide within the past 15 years. SVO's lack of sulfur means its emissions do not contribute to acid rain; similarly, because it is an agricultural product, burning it does not contribute to the greenhouse effect. Many studies indicate that particulate matter (or soot) is significantly reduced with SVO versus petrodiesel. However, data on engine wear and other important emissions is conflicting and incomplete.

Interest in both researching and using SVO, as it is with biodiesel, is stronger in Europe. European SVO is often virgin oil rather than waste oil because, for example, tax treatment in Germany makes its price similar to that of petrodiesel. Germany reportedly has more than 5,000 vehicles operating on SVO; the government even has a quality standard for canola oil fuel characteristics. (Canola oil is the dominant fuel used in Europe.) A fuel oil refining industry is in place that, together with government regulation, ensures high fuel quality. Although European SVO consumption is a fraction of European biodiesel consumption, it is clearly an emerging fuel that is acknowledged and regulated by at least some countries and, as such, is much further along than in the United States.

The benefits of cogeneration are well established even in the United States, where fuel and power costs are lower than those overseas. Small cogeneration systems are widely available, and significant experience has accumulated over the past 20 years regarding operation and interconnection with the power grid. The main attraction of cogeneration (more commonly called CHP or combined heat and power) is the financial savings in power and heat. In addition, plants with in-plant power generation are insulated to some extent from grid outages - a feature seen as more and more valuable as power interruptions increase and distribution lines age. For end users, the main disadvantages of cogeneration are distraction from the core business and, sometimes, technical problems and lost savings because of improperly designed or operated systems. The latter has been less of an issue in recent years as the general depth of experience with cogeneration has increased.

In general, cogeneration should be considered for any entity that requires significant process heating and particularly for organizations that are interested in being as energy-efficient as possible. 
This study examines the financial, technical, regulatory, and business feasibility of incorporating a cogeneration business function into the proposed Northeast Biodiesel LLC production facility. The system being considered is a diesel engine generator set modified to burn SVO and produce power to be sold to the growing renewable energy and prime power market in New England. This study was carried out by The WinterGreen Group of West Whately, Massachusetts, and funded by Co-opPlus of Western Massachusetts via a subcontract administered by the National Renewable Energy Laboratory. 


\section{Technical Analysis}

\subsection{Straight Vegetable Oil Versus Biodiesel}

Because petroleum diesel is a less viscous fuel than vegetable oil, using vegetable oil in a diesel engine requires either heating it or chemically altering it into biodiesel to make it thin enough to use in the diesel injection system.

Biodiesel is derived from vegetable oil but is chemically different. In chemical terms, vegetable oil is a triglyceride. A triglyceride molecule is composed of three fatty acid molecules linked to a glycerol molecule. Converting vegetable oil to biodiesel is usually done by a process of transesterification. Transesterification breaks off the glycerin (soap) and attaches each fatty acid to an alcohol molecule. Processes vary in detail, but a common method follows.

The first step involves breaking (or cracking) the ester-glycerin bonds. A catalyst-either sodium hydroxide or potassium hydroxide, both of which are also known as lye-is used for this step. Second, alcohol — either methanol or ethanol — is added to chemically bond with the fatty acid molecules and, essentially, make the oil thinner. The products of the reaction are alkyl esters (biodiesel) and glycerin. The main point of the transesterification process is to produce alkyl esters that will flow through, and combust properly in, modern diesel engines without damaging internal engine deposits.

\subsection{Why Straight Vegetable Oil?}

SVO fuel has many enthusiasts around the world, including individuals as well as organizations, university-based groups, and governmental bodies. These enthusiasts generally think biodiesel is fine, but they want to take a further step toward what they view as a sustainable, less processed, and - in the case of WVO - cheaper fuel.

The German manufacturer Elsbett, which pioneered diesel engine design modifications to optimize the burning of SVO, describes the advantages of SVO as:

- It has a high calorific value and high energy density.

- It is liquid in form and thus easy to handle.

- When burned, it emits less soot than petrodiesel.

- When burned, it has high energy efficiency.

- It is neither harmful nor toxic to humans, animals, soil, or water.

- It is neither flammable nor explosive and does not release toxic gases.

- It is easy to store, transport, and handle.

- It does not cause damage if accidentally spilled.

- Its handling does not require special care.

- It is produced directly by nature; it does not have to be transformed.

- It does not have adverse ecological effects when used.

- It does not contain sulfur; it does not cause acid rain when used.

- When burned, it is neutral in carbon dioxide; it makes no contribution to the greenhouse effect. 
Although somewhat repetitive (and translated from German), the sentiment is clear.

The following excerpt from Robert Beggs' Web site, Neoteric Biofuels, provides a layperson's introduction to using SVO as a diesel engine fuel.

(Rudolf) Diesel's first engines ran on peanut oil. Soon after, fossil oil (mineral oil) became widely available and inexpensive, and became the dominant fuel in the world. Engine and fuel system development for the diesel therefore became centered around "diesel fuel"- a less viscous fuel than vegetable oil. This is why we now have to use either the "heating" approach or the "biodiesel" approach to make vegetable oil thin enough to use in existing diesel injection systems.... We are adapting the fuel, rather than the engine or the existing fuel system. The (existing) fuel system remains intact, and the engine can use diesel fuel at any time.

Despite the fact that vegetable oil was used in early diesels, its reappearance on the fuels scene is relatively recent, so from that standpoint, it is a relatively unknown and underutilized fuel. This is changing quickly-there are now literally thousands of engines using SVO and also many on WVO (waste vegetable oil). User experiences have been generally positive, but because SVO does not have the extensive testing of diesel fuel or even of biodiesel, any SVO system should be considered to be "experimental."

Following is an excerpt from a typical enthusiast's Web site. In it, the National Outdoor Leadership School (NOLS, www.nols.edu/bus/bus_veggie.shtml) explains how it "took the plunge" and why.

The NOLS bus is powered by a diesel engine, specially converted to run on vegetable oil gathered and filtered from restaurants and dining halls during the NOLS on the Road year-long tour. Vegetable oil offers similar gas mileage as petroleum diesel but with fewer polluting emissions. Veggie oil also leaves behind a more pleasant alternative to the black cloud of diesel engine smoke - instead of that gagging diesel smell, the bus leaves in its wake the unmistakable smell of Chinese food, popcorn or French fries!

Converting a diesel engine to run on used veggie oil is easier than you'd think. It took NOLS about a week to do the conversion, which cost about $\$ 1,200$. All the parts were ordered online, and anyone with a basic working knowledge of car engines can do the conversion. And when it comes time to fill up at the pump, the savings of using veggie oil really add up. Why? Because veggie oil is free! In fact, most restaurants and dining halls are happy to get rid of their unwanted, leftover oil in order to avoid having to pay to have it removed .... 
Benefits of Vegetable Oil Fuel

When used in place of petroleum diesel, biodiesel and straight vegetable oil offer a wide range of environmental, health, economic and fuel security benefits. Vegetable oil burned as fuel does not emit sulfur dioxide $\left(\mathrm{SO}_{2}\right)$, a main compound in diesel responsible for acid rain. In addition to this $100 \%$ reduction in $\mathrm{SO}_{2}$, vegetable oil fuel produces $78 \%$ less carbon dioxide $\left(\mathrm{CO}_{2}\right)$, the dominant greenhouse gas responsible for global warming, $48 \%$ less carbon monoxide, a poisonous gas, $48 \%$ less asthma-causing particulate matter, and $80 \%$ less cancer-causing polycyclic aromatic hydrocarbons (PAHs) than petroleum diesel ....

The reasons cited for using SVO fuel are compelling and typical of the SVO community. However, no references were found on the NOLS Web site for the emissions figures cited above. The SVO community also includes scientists and others who often express a need for more detail and who raise questions about pouring WVO "directly into a converted diesel engine."

To begin with, there is wide variation among vegetable oils. A study from Australia discusses chemical nature and attributes of various vegetable oils.

A large amount of research has gone into examining Diesel's dream of using raw vegetable oils as fuels .... In the late 1970s and early 1980s, research was undertaken at Murdoch University (Perth, Australia) into the use of eucalyptus and other plant oils as a fuel component. In New Zealand, there are considerable problems with the disposal of surplus tallow from the processed meat industry and a large amount of work was conducted in the early 1980 s on the use of tallow as a fuel.

Experience has shown that the use of unsaturated triglyceride oils as a fuel may cause significant problems that can affect the viability of their fuel use. But this is not always the case, and in many circumstances these problems can either be dealt with or are acceptable to the user.

While power output and tailpipe emissions using plant or animal oils are in most cases comparable with those when running on petroleum diesel fuel, the main problem encountered has due to the higher viscosity of the triglyceride oils and their chemical instability. These can cause difficult starting in cold conditions, the gumming up of injectors and the coking-up of valves and exhaust. 
The viscosity of plant and animal fats and oils varies from hard crystalline solids to light oils at room temperature. In most cases, these "oils" or "fats" are actually a complex mixture of various fatty acids triglycerides, often with the various components having widely varying melting points. This may give the oil or fat a temperature range over which solidification occurs, with the oil gradually thickening from a thin liquid, through to a thick liquid, then a semi-solid and finally to a solid.

High melting points or solidification ranges can cause problems in fuel systems such as partial or complete blockage as the triglyceride thickens and finally solidifies when the ambient temperature falls.

... Many vegetable oils and some animal oils are "drying" or "semi-drying," and it is this [that] makes many oils such as linseed, tung, and some fish oils suitable as the base of paints and other coatings. But it is also this property that further restricts their use as fuels .... In the high temperatures commonly found in internal combustion engines, the process is accelerated, and the engine can quickly become gummed-up with the polymerized oil. With some oils, engine failure can occur in as little as 20 hours.

The traditional measure of the degree of bonds available for this process is given by the "Iodine Value" (IV) .... The IV can be easily reduced by hydrogenation of the oil (reacting the oil with hydrogen), the hydrogen breaking the double bond and converting the fat or oil into a more saturated oil [that] reduces the tendency of the oil to polymerize. However, this process also increases the melting point of the oil and turns the oil into margarine.

... Only coconut oil has an IV low enough to be used without any potential problems in an unmodified diesel engine. However, with a melting point of $25^{\circ} \mathrm{C}$, the use of coconut oil in cooler areas would obviously lead to problems. With IVs of 25-50, the effects on engine life are also generally unaffected if a slightly more active maintenance schedule is maintained such as more frequent lubricating oil changes and exhaust system decoking. Triglycerides in the range of IV 50-100 may result in decreased engine life and in particular to decreased fuel pump and injector life. However, these must be balanced against greatly decreased fuel costs (if using cheap, surplus oil), and it may be found that even with increased maintenance costs that this is economically viable. 
... The differences amongst fats and oils, whether of animal or vegetable origin, relate mainly to the level of saturation in the carbon chain. Generally speaking, the lower the number of double bonds, the higher the melting point of the triglyceride and the greater the stability of the triglyceride to polymerization and spontaneous oxidation. From an engine use point of view, it is preferable to use saturated fats as fuels as they are more stable and less resistant to oxidation, particularly under the elevated temperatures and pressures as found in an engine environment. However, due to their higher melting points, difficulty may be encountered in starting the engine without pre-heating of the fat. ${ }^{1}$

Clearly, all vegetable oils are not equal. The above study refers to virgin oil, not to WVO, which is often a mix of vegetable oils with waste materials from the cooking process. The following discussion, aimed at the backyard SVO enthusiast, summarizes well the practical issues involved in the use of SVO as a diesel engine fuel:

Does the SVO option work? Yes-If you go about it the right way. It's not quite that simple a choice. For one thing, if you want to use waste vegetable oil, which is often free, you're going to have to process it anyway, though less so than to make biodiesel. And it still might not be a very good fuel.

But read on - you can run your diesel motor safely on straight vegetable oil; just put it in and go. There are pitfalls and provisos, but we'll help you to steer your way through them.

Diesel motors last a long time: Half a million miles or more is not unusual, and there are very few thorough, long-term studies of the effects of using straight vegetable oil in diesel motors. What is clear, however, is that using "any" diesel engine or "any" SVO is an exaggeration.

- Some vegetable oils are more suitable than others.

- Some diesel engines are more suitable than others.

- Some injection pumps work better than others.

- Some computerized fuel systems don't like vegetable oil at all.

- There are doubts about using vegetable oil in DI (Direct Injection) diesels.

- There are also doubts about using waste vegetable oil

\footnotetext{
${ }^{1}$ Calais, P.; Clark, A.R. "Waste Vegetable Oil as a Diesel Replacement Fuel.” Environmental Science, Murdoch University, Perth, Australia, pcalais@ieee.org. Western Australian Renewable Fuels Association Inc., ar.clark@bigpond.com.
} 
The main problem is that vegetable oil is much more viscous (thicker) than conventional diesel fuel. It must be heated (thinned) so that it can be properly atomized by the fuel injectors. If it's not properly atomized, it won't burn properly, forming deposits on the injectors and in the cylinder head, leading to poor performance, higher emissions, and reduced engine life.

This can also happen with unsuitable oils, for instance those with a high iodine value, such as linseed oil, which can form tough epoxy deposits.

Waxes can clog up the fuel system, especially in cold weather. Untreated waste oils can contain acids that cause corrosion in the injector pump and impurities that can cause coking and further corrosion.

Nonetheless, experience is showing that SVO systems are a practical proposition with a lot of advantages to offer, not least of all that using SVO can be cheaper than turning it into biodiesel and uses less energy than making biodiesel does.

It's vital to pay close attention to the quality and condition of the oil—much more critical with an SVO system than if you're going to convert the oil into biodiesel.

Then get a good conversion system matched to the right kind of engine with the right kind of injection pump, as well as to your climate, and you'll be just fine, like thousands of others. ${ }^{2}$

Note the provisos with regard to type of oil, injection systems, and use of waste vegetable oil (WVO). Addison's promotion of SVO is tempered by experience, and his site offers one of the best places to start for anyone considering SVO fuel use.

\subsection{Burning Vegetable Oil in a Diesel Engine: Performance}

A number of tests on SVO as a diesel fuel have been conducted over the past 20 years. However, SVO is not nearly as well tested as biodiesel, partly because of a lack of interest from large funders and partly because of the large number of variables (e.g., fuel, engine, and additive types) involved. As a result (as Robert Beggs of Neoteric Biofuel noted above), any SVO system should be considered experimental.

Charles Peterson of the University of Idaho has done extensive work with SVO fuels in engines. The following excerpts are from two of his studies:

\footnotetext{
${ }^{2}$ From Keith Addison's JourneytoForever.org Web site, on which is compiled substantial scientific research, testimonials, and anecdotal experience about SVO, biodiesel, and petroleum diesel fuel.
} 
Most research with raw vegetable oils [has] shown reduced engine life due to polymerization in the ring belt area and, in some cases, lubricating oil thickening, reduced bearing life, or even sudden catastrophic failure .... ${ }^{3}$

When tested in long-term tests, (petrodiesel-biodiesel) blends above 20 percent nearly always result in engine damage or maintenance problems .... Many researchers have been involved in testing programs designed to evaluate long-term performance characteristics. Results of these studies indicated that potential hazards such as stuck piston rings, carbon buildup on injectors, fuel system failure, and lubricating oil contamination (Pratt, 1980) existed when vegetable oils were used as alternative fuels .... Engine tests showed that carbon deposits in the engine were reduced if the oil was heated prior to combustion. It was also noted that carbon deposit levels differed for oils with similar viscosities, indicating that oil composition was also an important factor. ${ }^{4}$

The latter study concluded:

Short-term engine testing indicates that vegetable oils can readily be used as a fuel source when the vegetable oils are used alone or are blended with diesel fuel. Long-term engine research shows that engine durability is questionable when fuel blends contain more than $20 \%$ vegetable oil by volume. More work is needed to determine if fuel blends containing less than $20 \%$ vegetable oil can be used successfully as diesel fuel extenders. ${ }^{6}$

\subsection{Burning Vegetable Oil in a Diesel Engine: Emissions}

Achieving complete combustion with SVO is clearly still a challenge. Some studies performed over the past few years show increased hydrocarbon and carbon monoxide emissions (versus diesel fuel), many showed increased particulate matter (soot), and others showed decreased soot. Some studies showed increased nitrogen oxides; others showed a decrease or no difference. Unregulated emissions such as PAHs were sometimes measured, and these showed dramatic increases or no difference, depending on the engine tested. ${ }^{5}$

The Australian study mentioned above, "Waste Vegetable Oil as a Diesel Replacement Fuel" by Phillip Calais and A.R. (Tony) Clark, notes that:

\footnotetext{
${ }^{3}$ Use of Raw Vegetable Oils as Diesel Fuel Replacements. University of Idaho. http://www.uidaho.edu/bae/biodiesel/rawoils.html.

${ }^{4}$ Jones, S.; Peterson, C.L. Using Unmodified Vegetable Oils as a Diesel Fuel Extender: A Literature Review. University of Idaho, September 2002.

${ }^{5}$ Biofuels Evaluation - Final Report of Test Programme to Evaluate Emissions Performance of Vegetable Oil Fuel on Two Light Duty Diesel Vehicles. United Kingdom Department for Transport, November 2003.
} 
Nitrogen oxides $\left(\mathrm{NO}_{\mathrm{x}}\right)$ emissions would most likely be similar or slightly elevated by $\sim 10 \%$ as compared to fossil diesel. In addition to atmospheric nitrogen, most vegetable and animal oils contain small quantities of nitrogencontaining proteins, which upon combustion, release various nitrogen oxides.

Unburnt hydrocarbon emissions may or may not be increased. Previous research has shown that this is very dependent of the vehicle's state of tune, age, and the specific properties of the oil. ${ }^{6}$

A literature review conducted by five scientists in 1996 and published by the Society of Automotive Engineers summarized published emissions measurements and compared results. The review begins with a discussion of engine testing procedures in the United States and the European Union, and the resulting variation in test results is based on different testing parameters. It indicates that, although SVO fuel produces greater hydrocarbons and carbon monoxide, it appears to produce the same level of nitrogen oxides and about half the soot. Results varied depending on whether the engine had a direct or indirect fuel injection system. Non-regulated emissions also appeared worse; however, the authors note that "PAH values reported in the literature are questionable." The review noted that "the type of oil, how it is pretreated, type of engine, and operating duty cycle all have significant impacts on emissions."

This study also discusses the toxicological issues related to diesel engine emissions:

The hydrocarbon emissions produced by motor traffic are either toxicologically of little relevance (alkanes, alkenes, as well as methane, ethane, or ethene) or can be carcinogenic (benzene, polycyclic aromatic hydrocarbons) .... The carbon monoxide emissions arising from engine combustion, aside from suffocation in closed rooms or garages, are insignificant in light of the other environmental problems caused by motor traffic ....

Oxides of nitrogen contribute to the formation of acid rain. When combined with volatile hydrocarbons or aldehydes in the presence of sunlight, the concentration of ozone at low altitudes increases .... NO exhaust emissions are at a low enough concentration that they are not perceived as a health risk. In contrast, $\mathrm{NO}_{2}$ is a lung irritant that attacks the membranes of human lung alveoli, even in small doses

... Polycyclic aromatic hydrocarbons (PAH) have become a known hazard for humans and the environment that must be taken seriously because of [their] carcinogenic and mutagenic properties.

\footnotetext{
${ }^{6}$ Waste Vegetable Oil As A Diesel Replacement Fuel, Phillip Calais, Environmental Science, Murdoch University, Perth, Australia, pcalais@ieee.org and AR (Tony) Clark, Western Australian Renewable Fuels Association Inc, ar.clark@bigpond.com
} 
... Even more complex is the association between the induction of lung tumors and diesel engine emissions .... Not only the PAH compounds adsorbed to soot particles have a strong cancer-inducing potential, but the assumption can be made that the PAH-free soot also induces carcinomas.

... Because PAH have a higher carcinogenic potential synergistically with soot particles than each component alone ... an estimation of the cancerinducing effect of exhaust gas is only possible when considering these compounds collectively. ${ }^{7}$

Such considerations may indicate why some pro-SVO sites mention soot, sulfur dioxides, and carbon dioxide reduction but do not discuss other emissions. The study concludes:

The data were not uniformly distributed when unmodified rapeseed oil was used as fuel. PAH and particulate matter concentrations were less modified with the use of rapeseed oil. Mutagenicity tests similarly show strong fluctuations.

At this time, research is still needed on the mutagenic and carcinogenic effects of particulate matter for both [biodiesel] and raw rapeseed oil. The continuing investigation on the influence of biofuels on soot particle size and concentration is also of importance. It should be reiterated that current knowledge indicates clear advantages for [biodiesel] regarding soot, particle, and PAH emission in conjunction with distribution of particles and mutagenic potential. Only non-uniform results were noted for raw rapeseed oil. $^{8}$

A study completed in November 2003 for the British Department of Transport compared two diesel vehicles' performance using SVO warmed to $80^{\circ} \mathrm{C}\left(170^{\circ} \mathrm{F}\right)$ with baseline United Kingdom ultra-low sulfur diesel fuel. One vehicle, a Peugeot 106, was equipped with indirect injection; the other, a Volkswagen Passat, had direct injection. Both vehicles showed significant increases in hydrocarbon and carbon monoxide emissions over ultra-low sulfur diesel. ${ }^{8}$

The following is from a study undertaken by a European consortium of research laboratories in July 2001. The study examined combustion mechanisms of oil spray and emissions characteristics for SVO, biodiesel (rape methyl ester or RME), and diesel fuel:

\footnotetext{
${ }^{7}$ Krahl; Munack; Bahadir; Schumacher; Elser. "Review: Utilization of Rapeseed Oil, Rapeseed Oil Methyl Ester, or Diesel Fuel: Exhaust Gas Emissions and Estimation of Environmental Effects." Krahl and Munack, Federal Research Center; Bahadir, Technical University; and Schumacher and Elser, University of Missouri, 1996.

8 "Biofuels Evaluation - Final Report of Test Programme to Evaluate Emissions Performance of Vegetable Oil Fuel on Two Light Duty Diesel Vehicles." United Kingdom Department for Transport, November 2003.
} 
Operating characteristics and emissions A comparative evaluation of the operating characteristics as well as the determination of the regulated and non-regulated exhaust gas emissions was carried out, including an investigation of the conversion rates of an oxidizing catalyst. In addition, engine performance and emission behavior was characterized in terms of structural parameters relating to vegetable fuels. Finally, variations were made in the fuel injection system of the test engine used in order to reduce the specific disadvantages of vegetable fuels. Different vegetable fuels were used and compared to diesel fuel.

... The emission results of unburned hydrocarbons, carbon monoxide, nitric oxides, and particulate matter confirm the advantages of RME in comparison to diesel fuel .... PAH emissions are distinctly better for all vegetable fuels, so there seems to be a much lower risk of cancer while using fatty acid methylesters as fuel.

... All the data have been compared with those obtained with a classical diesel oil under the same burning. Results indicate that rapeseed oil seems an effective substitute for diesel oil since it produces less soot and similar amounts of other pollutants. The presence of alcohol in the rapeseed oil improves the fuel and allows reduction in the preheating temperature.

... The chemical structure of the vegetable fuels has a great influence on engine performance and emission behavior. [Coconut and palm oil methyl esters] show best results concerning emissions of hydrocarbons, carbon monoxide, particulate matter, and PAH. RME gave the best results in terms of nitric oxides, power, and fuel consumption. The mixing of rape seed oil with non-vegetable substances leads to both negative and positive effects concerning different parameters. Variations of the fuel injection system of the diesel engine can lead to a clear reduction of the originally high $\mathrm{NO}_{\mathrm{x}}$ emissions of vegetable fuels.

... The overall combustion performance of the rapeseed oil is very satisfactory in comparison with the diesel fuel, while the rapeseed oil produces almost $40 \%$ less soot than diesel fuel. 
... Fuel structure and characteristics have been shown to have great influence on engine performance and emission behavior. One of the most important parameters is the spectrum of fatty acids. Length of carbon chains and number of double bonds in the fuel molecules affect low temperature suitability, spray formation, and carbon residue. Net calorific value and density also affect the energy content of cylinder charge. Short-chained coconut and palm kernel oil methyl ester have distinct emission advantages in terms of hydrocarbons, carbon monoxide, particulate matter, and polycyclic aromatic hydrocarbons but disadvantages as far as nitric oxides are concerned. ${ }^{9}$

In conclusion, the undisputed advantages of SVO fuel are in its sulfur-free emissions and reduced greenhouse gases. However, studies completed to date indicate that SVO may cause the same or worse levels of other emissions versus diesel fuel. The wide variability in SVO fuels, diesel engines, and baseline fuels studied (i.e., diesel, ultra-low sulfur diesel, biodiesel, and variations on these with fuel additives such as alcohol) means that only a small portion of the potential test matrix has been explored to date. Comparison is difficult because so few variables have been tested, and commonality of test variables is rare. In addition, few studies have been done to evaluate long-term effects of SVO use on engine durability. Few studies have examined WVO fuel emissions and none have a wide range of fuels that would allow comparison. In addition, there are issues of engine life that have not been adequately addressed to date.

\subsection{Fuel Pretreatment}

Fuel quality is a more critical issue when putting WVO directly in an engine than when converting it to biodiesel. All WVO should be filtered and, if necessary, de-acidified. The fuel should not contain water or fryer contaminates such as salt or phosphorus. The engine should be equipped with multiple filters, at least to 10 microns but preferably to 5 or even lower. Some recommend filtering SVO fuel to 1 micron. (The final filter micron rating should be as specified by the manufacturer for the fuel injection system, as this affects injection pressure.)

WVO has a tendency to have some free fatty acids. These have a tendency to cause soap to form instead of biodiesel when biodiesel is made from WVO. These free fatty acids may need to be removed.

Oil from the brassica family (e.g., mustard and canola, high-lubricity oils) seems to be among the best (or, as Keith Addison notes, at least there are more results available on using them in SVO applications).

\footnotetext{
9 “Advanced Combustion Research for Energy From Vegetable Oils Project Final Report.” 1998. http://www.nf-2000.org/secure/Fair/F484.htm.
} 
The following excerpt from a study undertaken in Thailand addresses issues related to pretreatment of SVO, including the tendency for some SVO enthusiasts to trumpet the "natural" characteristic of SVO in relation to biodiesel or diesel fuel:

... Reliable facts on pollution and engine damage produced by crude vegetable oil ... experimentation are hard to come by due to the general enthusiasm of the proponent entrepreneurs who are naturally somewhat coy about discussing their failures.

... That [SVO] is "untreated" is a myth - most oils have to be de-gummed, de-acidified, and usually winterized; [pretreatment] also involves chemical treatments, and there are centralized factories in Europe that do this for fuelgrade vegetable oil, much the same as for food-grade oils. Very few types of oil can go straight from the oilseed crusher to the fuel tank.

... The engines worked just fine on refined palm oil. That is oil [that] has been de-gummed with phosphoric acid and had fatty acids removed by saponification with sodium hydroxide. Yes folks! Sadly, you do need some chemicals and simple process engineering to make most vegetable oils work .... The process of refining puts the finished product into a price category comparable with the retail price of petrodiesel (including some tax). ${ }^{10}$

\subsection{Engine Design and Duty Cycle Optimization for Straight Vegetable Oil Fuel}

The evolution of the diesel engine from Diesel's time to what it is today is based on petrodiesel fuel, whose properties are quite different from those of vegetable oil. A number of studies over the past 20 years have contributed much to our understanding of optimizing SVO combustion in modern diesel engines. One of the biggest advantages of designing a system from scratch (as opposed to using SVO in an existing vehicle) is that lessons learned can be more easily incorporated.

Iowa State University's biodiesel Web site references a number of studies of SVO and notes:

\footnotetext{
${ }^{10}$ Allen, M. "Straighter-Than-Straight Vegetable Oils as Diesel Fuels." Message to the Biofuels-biz mailing list, Oct. 8, 2002. Michael Allen, visiting professor, Prince of Songkla University, Thailand.
} 
... The best experience with using raw oils in engine seems to come from indirect-injection engines and using only $5 \%-10 \%$ blends of the oil in diesel fuel. Most of the problems associated with the use of raw oils in engines are caused by higher viscosity. It has been suggested that these problems can be addressed by heating the oil (usually with engine coolant) and starting and stopping the engine with regular diesel fuel. This approach has been used with some success, although long-term durability has not been proven. ${ }^{11}$

The Advanced Combustion Research for Energy From Vegetable Oils study recommends the following:

Engines operating on vegetable oil fuels, even with preheated vegetable oil, need to be operated at higher loads and rpm than is the usual case, with frequent full-load operation. Idling and low load operation should be avoided .... It is not clear whether the combination of preheating to $\sim 70^{\circ} \mathrm{C}$ and blend with alcohol, diesel fuel, biodiesel, etc. would reduce or eliminate this problem, but since the emissions results are positive for this case, the further reduction of viscosity by combining preheating and blending might also improve combustion at low loads and at idle. Be aware that methanol does not mix well with vegetable oil and can harm diesels. Ethanol is better, but blends of ethanol and vegetable oil, and other alcohol/vegetable oil blends, can separate in storage, including in the tank, and especially as temperatures reach freezing and below. Therefore, research into "cosolvent" blends ... is worthwhile, and some studies have been conducted by various researchers. $^{12}$

Clearly, there is a need for more research into a number of scenarios if the resources and motivation can be found.

In summary, the following system characteristics appear to improve the likelihood of success when burning SVO in a diesel engine:

- Indirect fuel injection

- Fuel preheated to $160^{\circ}-180^{\circ} \mathrm{F}$

- Engine equipped with mechanical injection

- In-line injection pump

- Engine timing adjustment.

Other, more involved engine modifications are possible but may not be cost-effective.

\footnotetext{
${ }^{11}$ From the Biodiesel Education page of Iowa State University's Web site. www.me.iastate.edu/biodiesel/Pages/A.html.

12 “Advanced Combustion Research for Energy From Vegetable Oils Project Final Report.” 1998. http://www.nf-2000.org/secure/Fair/F484.htm.
} 
In the 1970s, the innovative Elsbett Co. of Germany developed an engine specifically designed to run on vegetable oil. Although this engine was never able to find a market, Elsbett also offers conversion equipment for standard diesel engines as well as expertise. It should be noted that Elsbett will not warranty its engine conversion kit on vehicles that use WVO (although, apparently, it has many customers who have done it).

It is recommended that the following (not meant to be a complete list) be consulted during the specification phase of any WVO engine genset and that appropriate modifications be incorporated into the final system design:

- Elsbett Co.

- Neoteric Biofuels

- Greasecar

- Charles Peterson of Iowa State University.

Because the long-term effects of SVO fuel in diesel engines are not well known, as indicated in the research reviewed previously, more frequent and in-depth maintenance practices are recommended. These should include:

- Regular injector inspection and cleaning, if indicated

- Head removal and combustion chamber cleaning, if indicated

- Regular lube oil sampling

- Regular checking/changing of fuel filters.

The starting and stopping fuel should be biodiesel or petrodiesel (high-quality), as the solvent properties of biodiesel and the additives in premium petrodiesel fuels can help remove any deposits that may form. In addition, the heat exchange and control system should be designed to ensure that no WVO is routed to the engine unless it is at the minimum desirable temperature.

All studies appear unanimous in stating that constant operation at steady, full load is best to reduce maintenance issues, extend engine life, and reduce emissions. For example, Darren Hill's Vegburner site states: 
Engine carbon build-up can be a problem with diesel-fuelled engines [that] have not been run hard or hot enough. It is advisable to work diesel engines hard fairly regularly to burn this carbon from the engine, more so when running on vegetable oil. Extended periods at low engine load are best avoided when possible. Combustion is less complete from when the engine is first started until it reaches operating temperature as the piston rings do not seal as efficiently until the various engine components have expanded with the combustion heat. It is good practice to accelerate to rated load to bring the engine up to operating temperature as soon as possible.

The SVO power plant is intended (and will be required by contract with electric power wholesalers) to run at rated power on a regular schedule throughout the year. Such steadystate operation should mitigate at least some of the maintenance issues noted above.

\subsection{Technical Analysis Conclusion}

Clearly, the use of SVO as diesel engine fuel is still somewhat experimental. However, enough experience exists to indicate that conditions can be optimized to reduce many of the factors that seem to cause problems. These include ensuring:

- Engine optimization, particularly of the fuel injection system

- Proper fuel pretreatment

- Heating of the fuel

- Starting and stopping with alternate fuels

- Steady-state mode of operation at rated load.

These elements lend themselves to optimization in a stationary, prime-power engine genset that is being purchased new. In addition, it is expected that the plant operating environment will promote better and more uniform fuel pretreatment. 


\section{Financial Analysis}

The attached financial pro forma examines the feasibility of the proposed WVO power plant. Key assumptions are:

\section{- Value of power sold}

According to Larry Chretien of the nonprofit energy cooperative Mass Energy, which aggregates renewable power, the value of RECs is about $\$ 0.03 / \mathrm{kWh}$ for a small system. (Mass Energy would need to aggregate the system with others to meet the minimum size required by the wholesale power market.) Along with base power revenue of $\$ 0.038 / \mathrm{kWh}$ (based on wholesale power spot pricing), the total revenue for the first 5 years of the system could be $\$ 0.068 / \mathrm{kWh}$. A fairly conservative assumption has been made as to the RECs value for ensuing years. Based on several industry representatives' comments, the value of RECs in years six through 15 is assumed at $\$ 0.024 / \mathrm{kWh}$, for a total of $\$ 0.063 / \mathrm{kWh}{ }^{13}$

Note that current REC contracts vary in length but generally are not as long as typical system life (for example, Mass Energy offered a 5-year contract). For this reason, the Massachusetts Renewable Energy Trust has implemented the Green Power program, which supports the long-term price risk for investors in renewable power systems. ${ }^{14}$ Under this program, the Massachusetts Renewable Energy Trust will enter into one of two types of contracts, both of which essentially commit to the purchase of RECs at a long-term price that allows renewable generators to seek financing on a better footing than present REC contracts allow. This program is open to any renewable fuel provider eligible for RECs under the RPS, but it is a competitive program. Nils Bolgen of the Massachusetts Renewable Energy Trust indicated that last year, the first year of the program, 11 proposals were received and six were awarded. System finances are based on a successful application to this program.

\footnotetext{
${ }^{13}$ Telephone conversation with Larry Chretien, Mass Energy, October 2004.

${ }^{14}$ Telephone conversation with Nils Bolgen, Green Power program director, Massachusetts Renewable Energy Trust, October 2004.
} 


\section{- Operating costs}

Overall operating costs for an industrial-sized biodiesel plant have been forecast by the Energy Information Administration of the Department of Energy to be \$0.16/gallon in 2005 and 2006. ${ }^{15}$ However, specific costs for electrical and thermal energy are necessary to determine the value of co-generated energy used in the plant. Such costs are often derived from very large plants; in addition, information is variable and conflicting.

Table 1. Biodiesel Plant Utility Consumption

\begin{tabular}{|c|c|c|}
\hline & Electrical Use/Gallon & Thermal Energy/Gallon \\
\hline Energy Information Administration ${ }^{16}$ & $0.083 \mathrm{kWh}$ & $38,300 \mathrm{Btu}$ \\
\hline Crown Iron Works Co. ${ }^{17}$ & $0.059 \mathrm{kWh}$ & 3,074 Btu \\
\hline Study - Kansas State University ${ }^{18}$ & $0.082 \mathrm{kWh}$ & $5,990 \mathrm{Btu}$ \\
\hline
\end{tabular}

Note that the latter two sources do not include cooling water, process water, compressed air, or other ancillary utilities. In addition, the above figures are for large plants (12 million-40 million gallons per year), in which utility costs per gallon of product will be lower. Note the particular discrepancy between the Energy Information Administration thermal energy figure versus the others. Given these uncertainties, and to be conservative in forecasting the cost-effectiveness of the CHP system, the following figures were used:

- Electrical use: $0.08 \mathrm{kWh} /$ gallon

- Thermal energy: 6,000 Btu/gallon.

\footnotetext{
${ }^{15}$ Energy Information Administration. “Annual Energy Outlook 2004.” Department of Energy/Energy Information Office 0383(2004). Washington, DC, January 2004. Table 3, "Industrial Gas and Electricity Prices."

${ }^{16}$ Radich, A. "Biodiesel Performance, Costs, and Use." Energy Information Administration.

${ }^{17}$ Anderson; Masterson; et al. "Industrial Biodiesel Plant Design and Engineering: Practical Experience." Crown Iron Works Co., Minneapolis, Minnesota, August 2003.

${ }^{18}$ Nelson; Howell; Weber. "Potential Feedstock Supply and Costs for Biodiesel Production" National Bioenergy Conference, 1994.
} 
The proposed biodiesel refinery is expected to begin at 2 million gallons per year production capacity and ramp up to 10 million gallons per year by 2007 or 2008 . It is assumed that provision for cogeneration will be installed during plant construction; however, actual installation of cogeneration equipment and its operation are not expected to occur until the plant is fully operational at its target capacity.

\section{- Value of co-generated energy used in-plant}

The value of electricity used in-plant was derived from the Small General Service Schedule G-O of Western Massachusetts Electric Co. This is the rate the plant would fall under (less than $350 \mathrm{~kW}$ demand). The rate is broken into a number of sections. Assuming a reasonable peak demand for the plant, and not including the base charge, the conservative assumption for electrical savings for in-plant generated power is $\$ 0.08 / \mathrm{kWh}$ on average. (No separate credit for demand savings is assumed.)

In the case in which thermal energy is valued, it is assumed that glycerin cannot be used and, therefore, WVO would be the boiler fuel. Therefore, the value of WVO is used in thermal savings calculations.

\section{- System cost}

The price for the cogeneration system is based on quotations from suppliers of the engine-genset system and the interconnection switchgear. Most engine vendors will offer financing for their equipment, and that is also shown. System and maintenance costs were obtained from Caterpillar-Milton in Brockton, Massachusetts, and Highland Power Inc., an engine-genset supplier and maintenance contractor based in Bridgewater, Massachusetts. (Highland Power also owns and operates several independent power systems that operate on experimental fuels.) Controls and switchgear costs were obtained from Ewing Control Systems, a cogeneration controls specialist based in Greenfield, Massachusetts, that has provided equipment to successfully interconnect with more than 50 utilities. Note that all interconnection switchgear will be IEEE-1547 compliant. Startup is included, as is a generous allowance for engine modifications to an SVO engine (both versions include fuel pre-heating). Installation costs were added to the packaged equipment costs as shown in the financial spreadsheets 


\section{- Capital investment}

A direct and modest investment of $\$ 20,000$ is assumed; the balance of the capital cost is assumed to be financed by the engine supplier at $8 \%$ together with a bank or other typical source for the remainder of the cost not covered by the engine supplier. Bank finance rates are assumed at $10 \%$.

\section{- Overhead and insurance}

The incremental cost of insurance for the plant with a power generation system versus without has been assumed at $\$ 12,000$ per year. In addition, $\$ 8,000$ has been included to cover corporate overhead to cover maintenance of financials and contractual and generation information system (GIS) paperwork.

- Maintenance

Maintenance per kilowatt-hour has been increased from the typical $\$ 0.01$ for diesel engines to $\$ 0.012$ to allow for more frequent maintenance and overhauls because of the experimental nature of SVO fuel. To be conservative, the same figure is retained for the biodiesel engine evaluation. Out-of-pocket costs of consumables such as filters and lube oil will average another $\$ 4,000-\$ 7,000$ per year, depending on system size.

\section{- Inflation}

Inflation rates have been assumed at $2 \%$ for insurance and operation and maintenance costs. However, $1 \%$ has been assumed for the value of co-generated power and thermal energy.

\section{- Value of thermal energy}

Biodiesel plants use substantial thermal energy for a number of functions, particularly for heating the vegetable oil feedstock to circulate it and for transesterification. Thermal energy can also be used for ancillary cooling functions via absorption technologies. As mentioned earlier, thermal value generally is the factor that makes a small-scale system such as this feasible. 
Biodiesel plants also produce a significant waste product with heat energy: glycerin. This glycerin has market value only if it is purified at substantial expense. Some indications are that approximately $60 \%$ may not be purifiable (particularly if WVO is used as the feedstock, as is planned) and would need to be disposed of. Because glycerin production is $10 \%$ of plant biodiesel production, disposal costs and regulatory issues are not trivial. Some biodiesel producers have burned glycerin for thermal needs and indicate that, if properly handled, it can be burned in boilers within allowable emissions limits. Burning some of the glycerin for plant thermal needs is a reasonable alternative to consider and experiment with if the necessary resources can be devoted to this undertaking.

If burning glycerin turns out to be undesirable, the boilers may be able to burn waste fatty acids or even low-quality WVO. Given the nature of the plant, there will likely be a usable waste fuel available at low cost to fuel the boilers. However, as long as the engine is operating, thermal energy will be available and, at times, may be the easiest approach.

This evaluation assumes WVO as the boiler fuel being replaced by co-generated heat from the engine set. In the SVO engine application, the boiler fuel price varies to match each permutation calculated. In the biodiesel engine application, the current market price for $\mathrm{WVO}$ of $\$ 1.22 / \mathrm{gal}$ is used unless the biodiesel cost is lower.

\section{- Value of engine fuel}

The value of biodiesel and SVO fuel is the key parameter in determining system feasibility. Various values are used based on current and projected figures available from the biodiesel industry and applicable literature as well as in-house generated figures. Note that per-gallon SVO costs include additional funds for pretreatment filtering and de-acidification. Also, given the slightly lower thermal value of SVO and biodiesel versus petrodiesel fuel and potential combustion inefficiencies, a generous factor of 1.2 has been used in the yearly fuel consumption calculation.

\section{- Results}

The graphs below show the effect of biodiesel and WVO engine fuel price on the feasibility of cogeneration at the plant. Internal rates of return were calculated for four system sizes at various fuel prices. Project feasibility improves as generation system size increases for all fuel prices. Note that all system sizes appear attractive even at above-market-rate WVO pricing. 
The SVO-fired cogeneration system is clearly more attractive than the biodiesel system. However, operational risk is also higher (see discussion under Business Analysis). If such risk is acceptable, the SVO option could be an excellent addition to Northeast Biodiesel's functions.

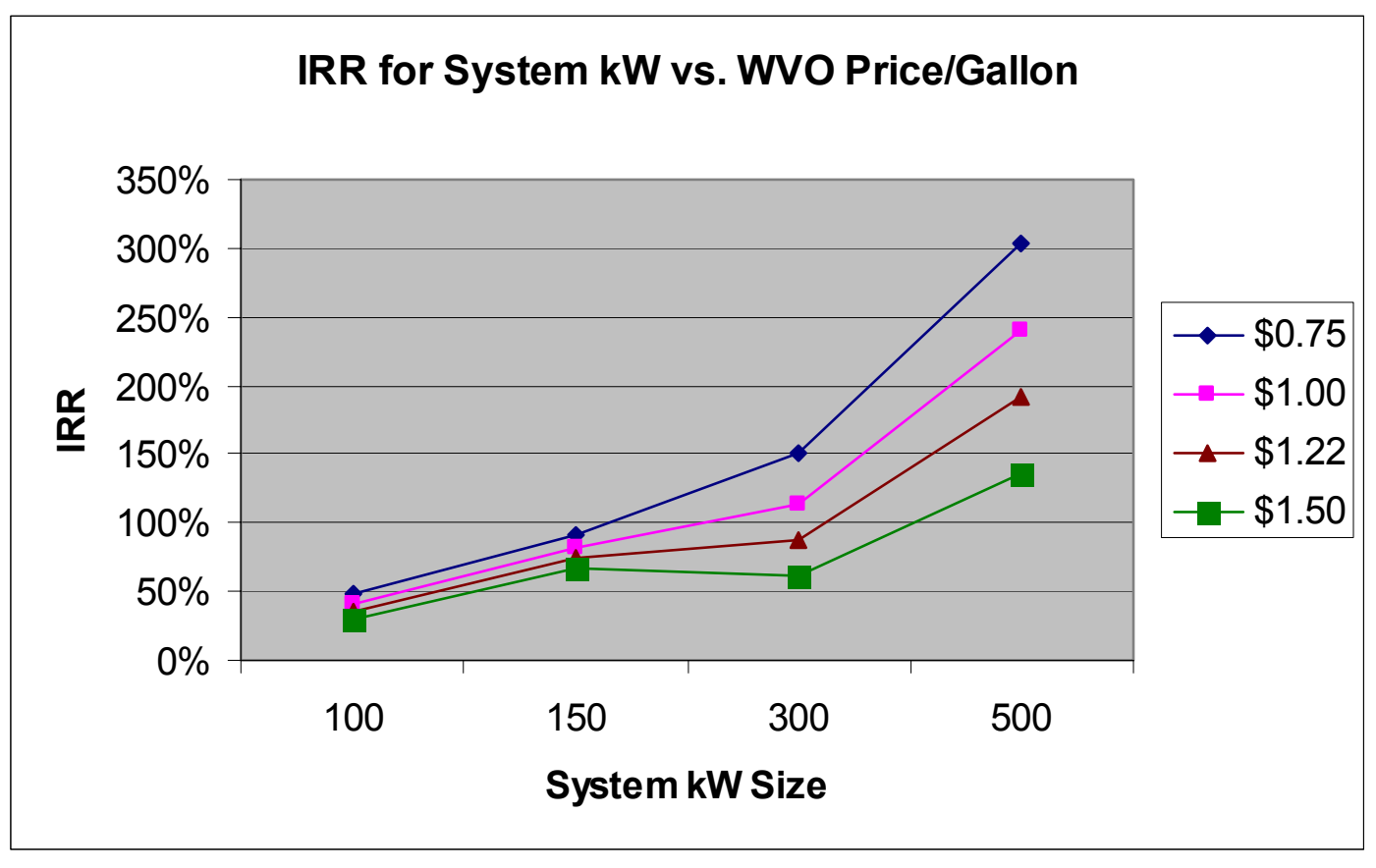

Figure 1. WVO internal rate of return 


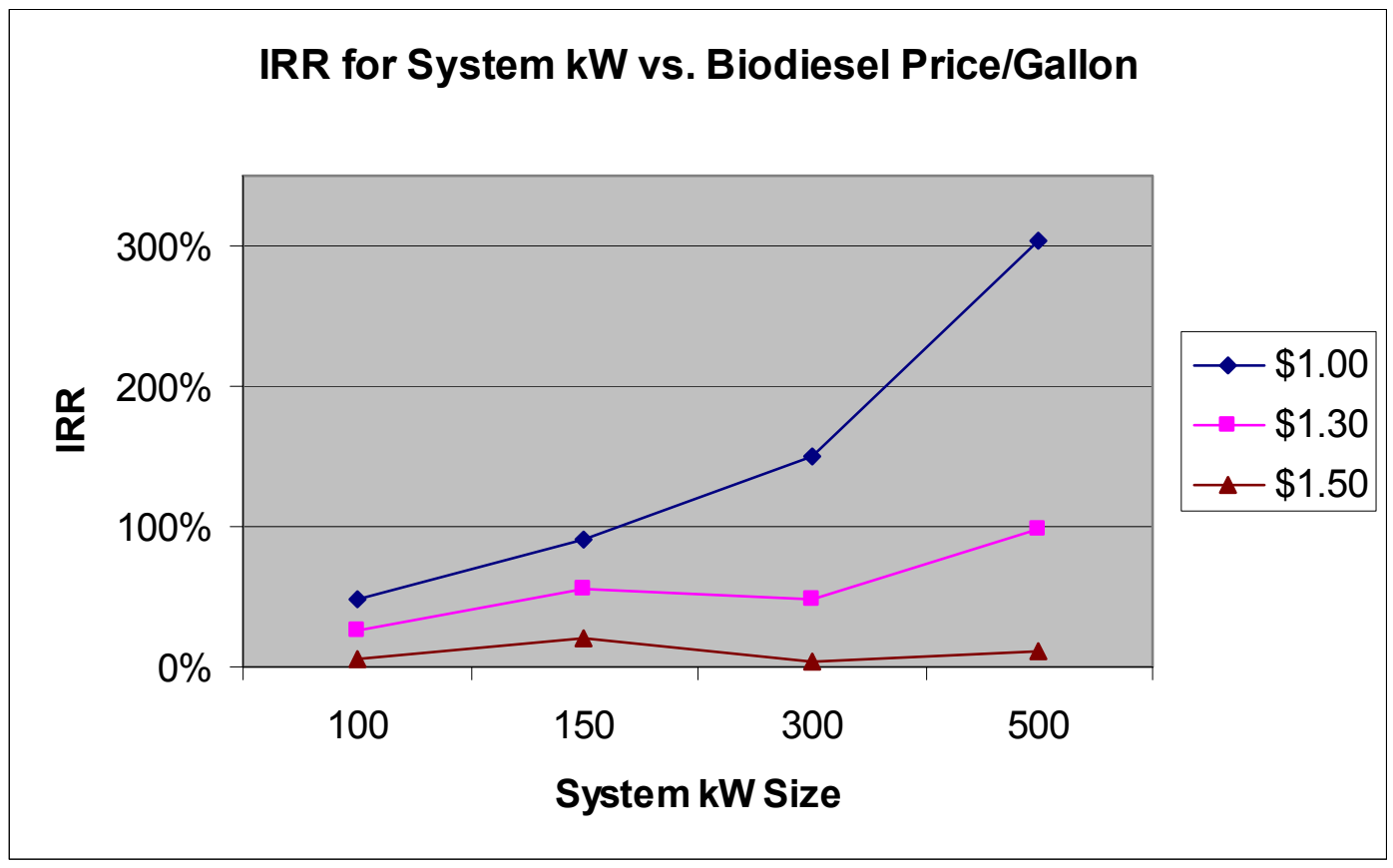

Figure 2. Biodiesel internal rate of return

A biodiesel-fired engine set system appears less attractive but still quite positive if an incremental cost of production (instead of market rate) price is used. In-plant production costs projected by Northeast Biodiesel range from $\$ 2.65$ at the start of plant operation to $\$ 1.27-\$ 1.36$ once the plant is stable and at target production levels. Clearly, plant size, and consequent production cost, is critical to cogeneration system feasibility. And as long as feedstock supplies are stable, cogeneration using biodiesel could be an excellent supplementary income to the plant.

The following table describes the ratio of co-generated thermal energy to that required by a 10-million-gallon/year biodiesel plant.

Table 2. Contribution to Thermal Load by Cogeneration System

\begin{tabular}{|l|l|l|l|}
\hline $\mathbf{1 0 0} \mathbf{~ k W}$ & $\mathbf{1 5 0} \mathbf{~ k W}$ & $\mathbf{3 0 0} \mathbf{~ k W}$ & $\mathbf{5 0 0} \mathbf{~ k W}$ \\
\hline $9.6 \%$ & $14.3 \%$ & $28.7 \%$ & $47.8 \%$ \\
\hline
\end{tabular}

Note that even if co-generated heat is used in-plant (as it must be if the cogeneration system is to be cost-effective) a backup heating plant must be installed. However, this plant could be designed around the future installation of the engine-set, and costs could be minimized in that expectation. For example, a set of smaller boilers intended to operate in tandem could be purchased. One or more of them could then be turned off when the engine-set is operating. 


\section{$4 \quad$ Regulatory Analysis}

\subsection{Eligibility for Renewable Energy Certificates}

The primary purpose of the power generation facility considered for Northeast Biodiesel is the income produced by selling power to the electricity market and, in particular, by selling the renewable attributes of this power via RECs. Eligibility for RECs is therefore critical to the success of this project.

The Massachusetts legislation that enabled the move to competition in the electricity market also included an RPS and other policies that create demand for clean, renewable generation. In the case of the Massachusetts RPS, retail electricity providers in Massachusetts must include a modest but growing amount of new renewable supply in all product offerings to customers. To satisfy their RPS obligations, the large retail providers in Massachusetts will be purchasing power from qualifying renewable projects in New England. The vehicle for earning this premium is the assignment and sale of RECs.

In New England, the market for renewable energy is facilitated by a regional GIS administered by APX Inc. under contract to the New England Power Pool. Any effective path to the market for renewable energy in New England requires effective participation in the GIS.

The GIS is a sophisticated database that tracks all the power generated and sold in New England. This is accomplished by assigning each electricity generator as well as any imports into New England one GIS certificate for every megawatt-hour of electricity production. By agreement, all generators and retailers in New England maintain accounts in the GIS and use these certificates to describe the mix of generation (e.g., the fuel sources, air emissions, and vintage) in their possession. If a GIS certificate is assigned to a megawatt-hour of electricity generated from a renewable energy system, that certificate is known as an REC.

GIS certificates are originally the property of the energy generators and are sold or traded to retail electricity providers that are actively controlling their mix of generators. When a renewable project owner sells its certificates to a retail electricity supplier or trader, the transaction is documented by the movement of certificates from the generator's account to the retailer's account in the GIS. Any certificates that are not specifically traded are automatically included by the GIS in the so-called residual mix and are allocated to all retailers based on their total customer load, losses, and active certificate purchases. 
The GIS system officially went into service Jan. 1, 2002. Since then, power plant owners are required to register each of their generators in the GIS database. In addition to identifying the owner and location of each generator, registration includes defining the characteristics (e.g., fuel type and air emissions) of each unit. To take advantage of the new market opportunities for renewable resources, renewable power system owners must get their systems registered as generators in the GIS. The system registration can be done by the system owner, or it can be completed by a third-party green power marketer on behalf of the system owner.

Retail electricity suppliers can acquire the certificates they need using purchase contracts that cover both the underlying power and certificates produced by the generator in a single combined transaction or through the purchase of certificates independent from the sale of power.

The premium value of GIS certificates produced by renewable energy generators will be determined by market conditions, including the supply and demand of renewable certificates of various types, their resource type and vintage, and the terms and other conditions under which they are purchased. Green power marketers will generally take on this market risk and sign 1-5 year contracts with power system owners at fixed prices over the term of the contract for the RECs produced by their system. ${ }^{19}$

Biodiesel has been accepted as a renewable fuel under the RPS. However, if a WVO-fired engine set is to be considered, it is first necessary to determine whether WVO is an eligible renewable fuel under the RPS. The Massachusetts DOER is responsible for implementing the RPS. Howard Bernstein of the DOER indicated that, although "vegetable oil [was] definitely eligible" under the RPS, it would be necessary to obtain an "advisory ruling" from DOER to determine whether this generation unit would qualify as a "new renewable generation unit." Advisory rulings have been sought for other biomass generation systems because biomass is cited as an eligible fuel only under 225 CMR 14.05 "Eligibility Criteria for New Generation Units," which states under section (1) that "The generation unit shall use one or more of the fuels, energy resources, and/or technologies listed below." Biomass falls under the sixth listing as: "Low-emission, advanced biomass power conversion technologies using an eligible biomass fuel." This description leaves room for interpretation and this is why an advisory ruling is required for all biomass power conversion systems proposed in Massachusetts that intend to sell RECs.

\footnotetext{
${ }^{19}$ Renewable Generator Certificate Trading Handbook. Solar Energy Business Association of New England, December 2003.
} 
The advisory ruling application should include a description of the proposed fuel and power generation system and include fuel attributes and justification of the ways it meets the requirements of and promotes the intent of the RPS. DOER indicated that, although obtaining an advisory ruling was a necessary step, a favorable ruling was likely.

\subsection{Emissions Permitting}

New DEP regulations [310 CMR 7.26 (40)-(44)] regarding engines that will affect permitting for this system will likely go into effect mid-2005. Current regulations exempt prime power systems such as this ("peaking power production units, load-shaving units, units in an energy assistance program") if they are less than 3 million Btuh input (about 300 $\mathrm{kW}$ ) and if they are running prior to the date the new regulations take effect. However, Bob Donaldson of the DEP made clear that once the new regulations take effect, engines as small as $50 \mathrm{~kW}$ must comply with the new regulations. These require that such engines be certified that their emissions fall under specific limitations for nitrogen oxides, particulate matter, carbon monoxide, and carbon dioxide. This approach could be followed if biodiesel is used, as manufacturers now have published data on such emissions. As far as an SVOfired engine set is concerned, the DOER has asked the DEP to confer with it on a case-bycase basis to determine exactly what "low emissions" might mean for an "advanced biomass power conversion technology," as described in state regulations.

In this case, a "comprehensive plan application" that lists emissions estimates can be filed. This approach, which allows DEP to review new technologies on a case-by-case basis, may be the most likely path for an SVO-fired engine genset. Depending on DEP's determination, BACT (best available control technology) might be prescribed in addition to a program of monitoring and testing.

The experiences of other biomass plants that have gone through this process were examined. For example, the Biomass Energy Resource Center is a demonstration gasifier project proposed for Heyes Forest Products in Orange, Massachusetts. The gasifier would produce gas from the combustion of wood, and the gas would co-fire a diesel genset along with petrodiesel. According to the DOER advisory ruling on Heyes, although the diesel portion of the generated power will not be eligible for RECs, the cutting-edge aspect of the gasifier will allow the system to meet the "advanced technology" criterion of the RPS regulations. In addition, the ruling states:

DOER also believes that biomass technologies should improve over time in response to the incentives created by the RPS, added to the other regulatory and market forces responsible for continued technological progress in the electricity generation sector generally. 
This and other RPS criteria should be kept in mind when preparing the request for advisory ruling to DOER as well as the comprehensive plan application to DEP. 


\section{Business Analysis}

The decision to go into power generation as a business division supporting the core business has many implications. These include financial and resource allotment issues as well as diversion of management attention and effect on strategic direction/flexibility of the core biodiesel production business.

\subsection{Effects on Base Business Resources}

Base business resources include physical space, operating labor and costs, and management time.

The power generation equipment itself requires approximately 1,000-1,500 $\mathrm{ft}^{2}$, including the engine-generator and switchgear, day tank, and filtering, heating, and pretreatment (deacidification) equipment. A large fuel storage tank would be part of the initial production facility. Ideally, the plant layout would be arranged to minimize piping distances.

The power generation switchgear would ideally be integrated into the plant service entrance gear. This is the optimum arrangement and would minimize costs. The service entrance gear can be designed to easily accommodate a future breaker for the power production system.

Management time will not be trivial. Initially, aside from equipment procurement and construction management, it will involve time spent setting up contracts with electricity brokers, certifying the system with the New England Power Pool's GIS, registering with the Massachusetts Renewable Power System, and complying with all required paperwork to get the system up and running. On an ongoing basis, work will involve issuing quarterly metering and emissions reports and carrying on other required communication with the power aggregation broker, plus arranging for repairs, ordering parts, and allocating other required resources to deal with engine operation, maintenance, and repair.

\subsection{Effects on Core Business - Strategic Risks}

The effects of a renewable electricity generation system on the core biodiesel production business are twofold: financial and strategic. The financial effect, as shown in the attached pro forma spreadsheets, is quite positive, especially as system size increases. As discussed in the Financial Assessment section of this study, positive cash flow is based on key assumptions about feedstock availability and cost. However, the pro forma fuel prices shown indicate good chances for an excellent return. 
The major strategic risk is feedstock availability at an acceptable price. This risk is compounded by the nature of RECs and wholesale power contracts, in which the company would be legally committed to generate a certain amount of power per unit of time. Should fuel costs exceed those expected, the effect on the business would be negative and hardly a support to the base business.

Following are the annual cogeneration system fuel requirements based on system size. These figures are relatively low versus a 10-million-gallon/year horizon; however, they are substantial. Should WVO resources be lower than expected, or should the plant experience occasional feedstock shortages, the plant could be put into the uncomfortable and perhaps disastrous position of having to choose which contract to honor: the contracts with power brokers or with key biodiesel customers. This could have drastic effects on its attempt to build or expand the base biodiesel business.

Table 3. Cogeneration System Fuel Requirements

\begin{tabular}{|l|l|l|l|}
\hline $\mathbf{1 0 0} \mathbf{~ k W}$ & $\mathbf{1 5 0} \mathbf{~ k W}$ & $\mathbf{3 0 0} \mathbf{~ k W}$ & $\mathbf{5 0 0} \mathbf{~ W W}$ \\
\hline 69,000 gallons/year & 96,000 gallons/year & 209,700 gallons/year & 339,000 gallons/year \\
\hline
\end{tabular}

Other risks include the vagaries of the wholesale power market and the likelihood of REC and base power prices increasing, remaining the same, or decreasing (as RECs are expected to do). Although still in the energy business, generating and selling power is a vastly different business from selling heating and vehicle fuel.

SVO cogeneration appears more attractive from the point of view of fuel cost. However, the knowledge base surrounding biodiesel is at present much larger than that surrounding SVO. The uncertainties surrounding the burning of WVO in engines - including possible reduced engine life and maintenance intervals - and emissions uncertainties constitute further risks.

Finally, and no small issue, is the potential for distraction. The base business of biodiesel production will require significant mental, emotional, and financial focus over a long period of time to be successful. Any ancillary business would have to offer significant positive rewards to outweigh the risks inherent in attempting to build two businesses simultaneously. Of course, additional financial resources could solve this particular problem. 
In conclusion, installation of a biodiesel- or SVO-fueled cogeneration system at the Northeast Biodiesel production facility appears quite attractive once the plant is operating at a stable and profitable level. In considering either fuel, a venturesome spirit and strong desire for success will be required. However, because both are present in any entity entering today's nascent biodiesel industry, the key question will be one of risk evaluation given the numerous other demands facing the biodiesel pioneer.

\subsection{Replicability: Biodiesel- and Straight Vegetable Oil-Fueled Distributed Generation Systems}

Installing biodiesel-fired cogeneration at other industrial plants or large commercial and institutional settings could be cost effective if:

- Plant thermal and electrical load is substantial

- Fuel can be obtained at an attractive price.

These elements hold true for the evaluation of any cogeneration system, of course. In this case, however, the Northeast Biodiesel application has a major advantage that other plants will not: the availability of in-plant produced fuel at an "internal," cost-of-production price. SVO-fired distributed generation is still further afield; only the most risk-tolerant would consider it. Given the perceived risk of even standard cogeneration, SVO-fired cogeneration is probably unlikely. If, however, someday there are vegetable fuel-oil refining plants in the United States similar to those in Europe, SVO power plants could be a standard element in distributed generation.

As the market price of biodiesel declines, the situation could change drastically. Currently, fuel price is one of the main impediments to successful cogeneration with biodiesel-fired engines. However, it is not the only one.

It is instructive to examine the market for one of the most successful models in this size range: natural gas-fired engine-based cogeneration. Currently, it is quite successful in the right circumstances (e.g., advantageous fuel contracts, larger system sizes, high thermal loads) and reasonable permitting environments. However, natural gas-fired CHP systems are not as widespread as the economics alone might predict. This is due to several factors:

- Utility costs constitute a relatively low percentage of operating costs for most corporations, regardless of type. As a result, energy-reduction efforts tend to be off the corporate radar screen.

- Scarce capital resources are most often devoted to core business functions rather than what is perceived as non-critical or sideline efforts such as CHP. This factor is lessened somewhat by the typical energy services company approach, in which no capital outlay is required and savings are shared. However, even with this approach, it is often difficult to get the attention of decision makers as support facilities (such as boiler plants) in general tend to suffer from "line versus staff" treatment from corporate leadership. 
- Finally, most corporate leadership is reluctant to get involved in ventures they perceive as unrelated to the core mission. Many simply do not want to get involved in the business of electricity generation. It is not something they know, and it is often perceived as risky. Finally, they can buy all the electricity they want from the grid.

In the absence of significant tax breaks (such as those put in place by California), the unfortunate result of the above factors is that distributed generation simply has not achieved widespread market acceptance. This is despite years of work by energy pioneers and government agencies.

However, there has been significant progress since the energy crisis of the '70s. CHP equipment works better, lasts longer, and is less expensive. A host of system variations are available, and new IEEE and Underwriters Laboratories standards have brought rationality to one of the most frustrating problems with DG: varying utility interconnection requirements and a general lack of key standards.

CHP is extremely popular in Europe, and there is a simple reason: Fuel and energy costs are significantly higher than those in the United States. If and when national energy costs rise, interest in CHP and distributed generation of all types should explode. 
Appendix. Pro Forma Financial Spreadsheets 
Table A-1. Capital Costs for Cogeneration System

\begin{tabular}{lrrr}
\hline kW & Total Genset* $^{*}$ & Interconnection Switchgear & Total System Cost \\
\cline { 2 - 4 } & & & \\
$\mathbf{5 0 0}$ & $\$ 312,000$ & $\$ 42,000$ & $\$ 354,000$ \\
$\mathbf{3 0 0}$ & $\$ 188,000$ & $\$ 35,000$ & $\$ 223,000$ \\
$\mathbf{1 5 0}$ & $\$ 102,000$ & $\$ 28,000$ & $\$ 130,000$ \\
$\mathbf{1 2 5}$ & $\$ 88,000$ & $\$ 25,450$ & $\$ 113,450$ \\
$\mathbf{1 0 0}$ & $\$ 76,000$ & $\$ 25,450$ & $\$ 101,450$ \\
$\mathbf{7 0}$ & $\$ 68,000$ & $\$ 25,450$ & $\$ 93,450$
\end{tabular}

${ }^{*}$ Costs include margin for consultation and engine modifications for these alternate fuels

Interconnection Switchgear:

IEEE 1547-compliant

Utility-grade protective relaying

Interconnection circuit breaker

Controls for synchronizing with grid

\section{Genset Package}

Engine generator on base plate with vibration isolation

Muffler and sound enclosure

Heat recovery systems (jacket water and exhaust gas)

Lubrication system

Controls

Ventilation blowers

Battery starting system

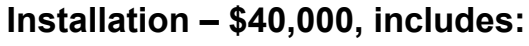

Ventilation: Extension of system to building exterior

Concrete work: Spill containment and engine foundation (difference from standard)

Fuel system piping to plant tankage

Heat Recovery: Balance of system, including circulator, expansion tank, and controls 
Table A-2. Biodiesel Facility Biodiesel Cogeneration

Enter in yellow boxes: $k W$ in "Eng Rating", Fuel

Consumption, Engine System Cost, and Fuel Cost.

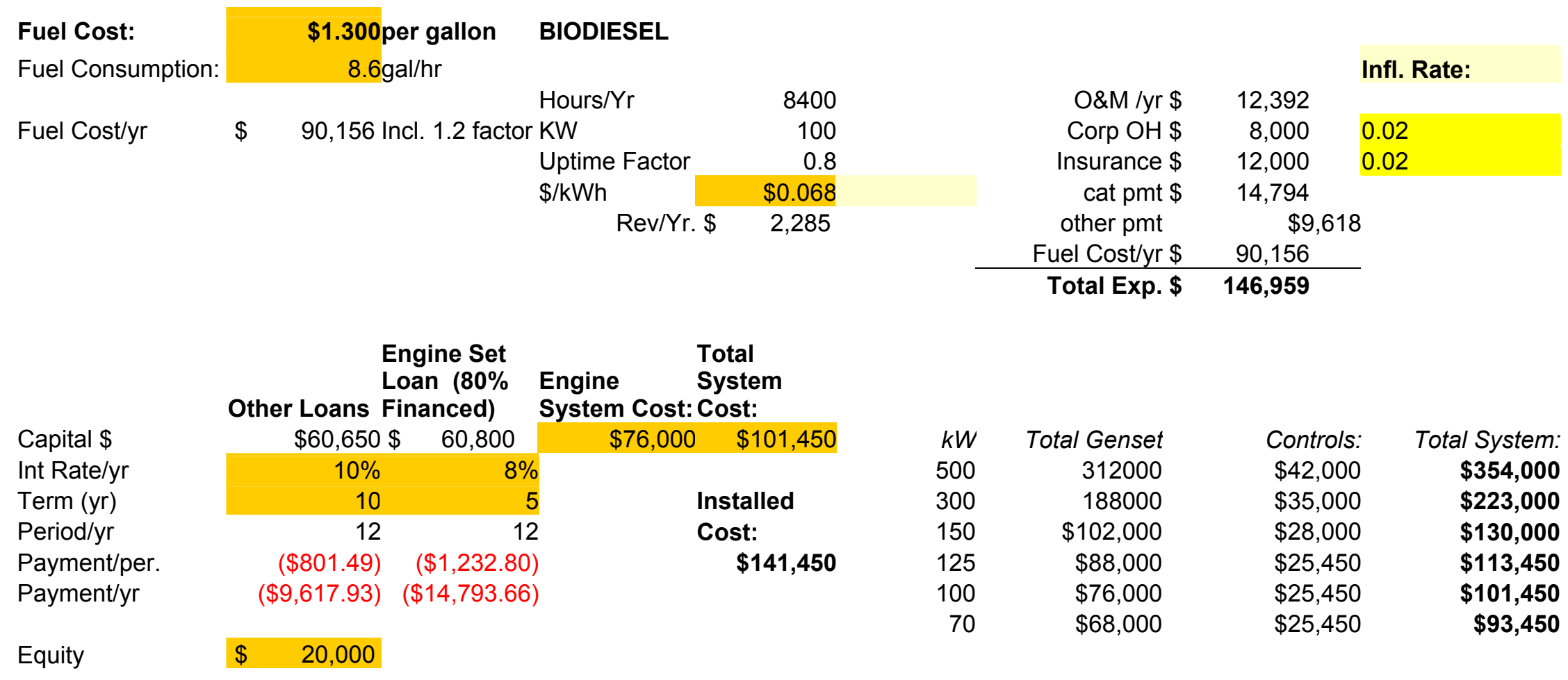

Eng Rating

$100 \mathrm{~kW}$ 


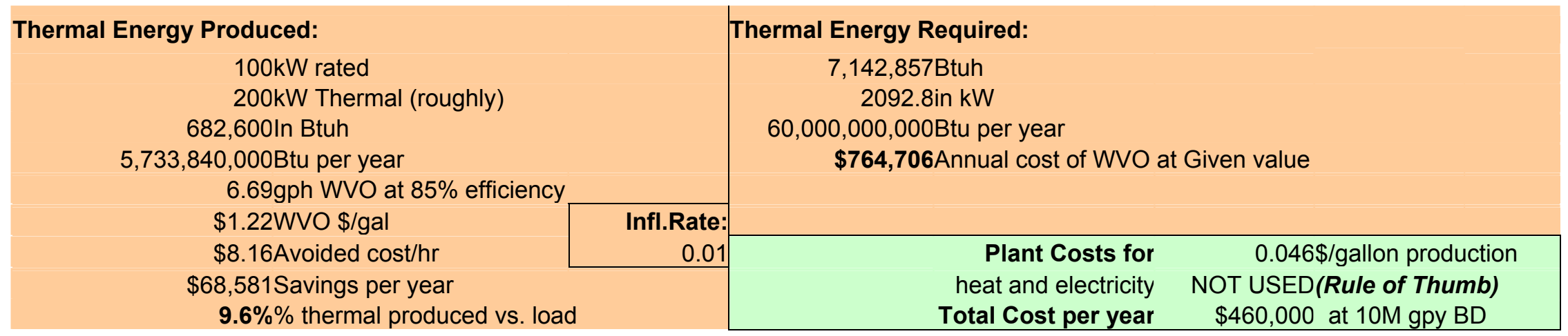

Plant Electrical Consumption:

\begin{tabular}{rrrrr} 
Ave kW Use & \multicolumn{2}{c}{} & \multicolumn{2}{c}{$\boldsymbol{k W : G p h}$ (diesel) } \\
Peak kW Need & 950 & & 30 & 2.6 \\
kWh/year & 798,000 & Infl.Rate & 50 & 4.4 \\
Value \$/kwh & 0.08 & 0.01 & 70 & 5.6 \\
Value of kWh displaced: & $\$ 63,840.00$ & & 100 & 8.6 \\
& & & 125 & 10.1 \\
Rule of thumb: & 95Ave kW usage & 150 & 11.9 \\
& & 300 & 26.0 \\
& & 500 & 42.0
\end{tabular}

Genset Fuel Consumption: 
Table A-3. Biodiesel Facility Biodiesel Cogeneration Income Statement

\begin{tabular}{|c|c|c|c|c|c|c|c|c|c|c|c|c|c|c|c|}
\hline & & 1 & & 2 & & 3 & & 4 & & 5 & & 6 & & 7 & 8 \\
\hline kW Actual & & 100 & & 100 & & 100 & & 100 & & 100 & & 100 & & 100 & 100 \\
\hline O\&M & $\$$ & 12,392 & $\$$ & 12,516 & $\$$ & 12,641 & $\$$ & 12,767 & $\$$ & 12,895 & $\$$ & 13,024 & $\$$ & 13,154 & 13,286 \\
\hline Insurance & $\$$ & 12,000 & $\$$ & 12,240 & $\$$ & 12,485 & $\$$ & 12,734 & $\$$ & 12,989 & $\$$ & 13,249 & $\$$ & 13,514 & 13,784 \\
\hline Corp. OH & $\$$ & 8,000 & $\$$ & 8,160 & $\$$ & 8,323 & $\$$ & 8,490 & $\$$ & 8,659 & $\$$ & 8,833 & $\$$ & 9,009 & $\$ \quad 9,189$ \\
\hline Engine Loan & $\$$ & 14,794 & $\$$ & 14,794 & $\$$ & 14,794 & $\$$ & 14,794 & $\$$ & 14,794 & & & & & \\
\hline Other Loan & $\$$ & 9,618 & $\$$ & 9,618 & $\$$ & 9,618 & $\$$ & 9,618 & $\$$ & 9,618 & $\$$ & 9,618 & $\$$ & 9,618 & 9,618 \\
\hline Fuel Cost & $\$$ & 90,156 & $\$$ & 90,156 & $\$$ & 90,156 & $\$$ & 90,156 & $\$$ & 90,156 & $\$$ & 90,156 & $\$$ & 90,156 & $\$ 90,156$ \\
\hline Total Expenses & $\$$ & 146,959 & $\$$ & 147,483 & $\$$ & 148,016 & $\$$ & 148,559 & $\$$ & 149,111 & $\$$ & 134,879 & $\$$ & 135,451 & $\$ 136,033$ \\
\hline \$/kwh & $\$$ & 0.068 & $\$$ & 0.068 & $\$$ & 0.068 & $\$$ & 0.068 & $\$$ & 0.068 & $\$$ & 0.063 & $\$$ & 0.063 & 0.063 \\
\hline Income from KWH Sales & $\$$ & 2,285 & $\$$ & 32,150 & $\$$ & 32,150 & $\$$ & 32,150 & $\$$ & 32,150 & $\$$ & 29,786 & $\$$ & 29,786 & 29,786 \\
\hline Value of Thermal used internally & & $\$ 68,581$ & $\$$ & 69,267 & $\$$ & 69,960 & $\$$ & 70,659 & $\$$ & 71,366 & $\$$ & 72,080 & $\$$ & 72,800 & 73,528 \\
\hline Value of kWh used internally & $\$$ & 51,072 & $\$$ & 51,583 & $\$$ & 52,099 & $\$$ & 52,620 & $\$$ & 53,146 & $\$$ & 53,677 & $\$$ & 54,214 & $\$ 54,756$ \\
\hline Gross Income & $\$$ & 121,938 & $\$$ & 153,000 & $\$$ & 154,209 & $\$$ & 155,429 & $\$$ & 156,662 & $\$$ & 155,543 & $\$$ & 156,801 & $\$ 158,071$ \\
\hline Net Income & & $(25,021)$ & $\$$ & 5,517 & $\$$ & 6,192 & $\$$ & 6,870 & $\$$ & 7,551 & $\$$ & 20,664 & $\$$ & 21,350 & 22,038 \\
\hline
\end{tabular}




\begin{tabular}{|c|c|c|c|c|c|c|c|c|c|c|c|c|c|}
\hline & 9 & & 10 & & 11 & & 12 & & 13 & & 14 & & 15 \\
\hline & 100 & & 100 & & 100 & & 100 & & 100 & & 100 & & 100 \\
\hline$\$$ & 13,419 & $\$$ & 13,553 & $\$$ & 13,688 & $\$$ & 13,825 & $\$$ & 13,964 & $\$$ & 14,103 & $\$$ & 14,244 \\
\hline$\$$ & 14,060 & $\$$ & 14,341 & $\$$ & 14,628 & $\$$ & 14,920 & $\$$ & 15,219 & $\$$ & 15,523 & $\$$ & 15,834 \\
\hline$\$$ & 9,373 & $\$$ & 9,561 & $\$$ & 9,752 & $\$$ & 9,947 & $\$$ & 10,146 & $\$$ & 10,349 & $\$$ & 10,556 \\
\hline$\$$ & 9,618 & $\$$ & 9,618 & $\$$ & - & $\$$ & - & $\$$ & - & $\$$ & - & $\$$ & - \\
\hline$\$$ & 90,156 & $\$$ & 90,156 & $\$$ & 90,156 & $\$$ & 90,156 & $\$$ & 90,156 & $\$$ & 90,156 & $\$$ & 90,156 \\
\hline$\$$ & 136,625 & $\$$ & 137,228 & $\$$ & 128,224 & $\$$ & 128,848 & $\$$ & 129,484 & $\$$ & 130,131 & $\$$ & 130,789 \\
\hline$\$$ & 0.063 & $\$$ & 0.063 & $\$$ & 0.063 & $\$$ & 0.063 & $\$$ & 0.063 & $\$$ & 0.063 & $\$$ & 0.063 \\
\hline$\$$ & 29,786 & $\$$ & 29,786 & $\$$ & 29,786 & $\$$ & 29,786 & $\$$ & 29,786 & $\$$ & 29,786 & $\$$ & 29,786 \\
\hline$\$$ & 74,264 & $\$$ & 75,006 & $\$$ & 75,756 & $\$$ & 76,514 & $\$$ & 77,279 & $\$$ & 78,052 & $\$$ & 78,832 \\
\hline$\$$ & 55,304 & $\$$ & 55,857 & $\$$ & 56,415 & $\$$ & 56,979 & $\$$ & 57,549 & $\$$ & 58,125 & $\$$ & 58,706 \\
\hline$\$$ & 159,354 & $\$$ & 160,649 & $\$$ & 161,958 & $\$$ & 163,280 & $\$$ & 164,615 & $\$$ & 165,963 & $\$$ & 167,325 \\
\hline$\$$ & 22,728 & $\$$ & 23,421 & $\$$ & 33,734 & $\$$ & 34,431 & $\$$ & 35,131 & $\$$ & 35,832 & $\$$ & 36,535 \\
\hline & & & & & & & & & & & & \multicolumn{2}{|c|}{$25.52 \%$} \\
\hline & & & & & & & & & & & & \multicolumn{2}{|c|}{ IRR } \\
\hline
\end{tabular}


Table A-4. Biodiesel Facility Straight Vegetable Oil Cogeneration

Enter in yellow boxes: $k W$ in "Eng Rating",

Fuel Consumption, Engine System Cost, and Fuel Cost.

\begin{tabular}{|c|c|c|c|c|}
\hline \multirow{2}{*}{$\begin{array}{l}\text { Fuel Cost: } \\
\text { Fuel Consumption: }\end{array}$} & & $\$ 0.400$ per gallon & \multicolumn{2}{|l|}{ svo } \\
\hline & & $8.6 \mathrm{gal} / \mathrm{hr}$ & & \\
\hline & & & Hours/Yr & 8400 \\
\hline \multirow[t]{3}{*}{ Fuel Cost/yr } & $\$$ & 27,740 Incl. 1.2 factor & $\mathrm{KW}$ & 100 \\
\hline & & & $\begin{array}{l}\text { Uptime Factor } \\
\$ / k W h\end{array}$ & $\begin{array}{r}0.8 \\
\$ 0.068\end{array}$ \\
\hline & & & Rev/Yr. & 2,285 \\
\hline
\end{tabular}

\begin{tabular}{|c|c|c|}
\hline & & Infl. Rate: \\
\hline O\&M /yr \$ & 12,392 & \\
\hline Corp OH \$ & 8,000 & 0.02 \\
\hline Insurance \$ & 12,000 & 0.02 \\
\hline cat pmt \$ & 14,794 & \\
\hline other pmt & \multicolumn{2}{|c|}{$\$ 9,618$} \\
\hline Fuel Cost/yr \$ & \multicolumn{2}{|c|}{27,740} \\
\hline Total Exp. \$ & \multicolumn{2}{|l|}{84,544} \\
\hline
\end{tabular}

Capital \$
Int Rate/yr
Term (yr)
Period/yr
Payment/per.
Payment/yr

Engine Set Loan Engine

Total System

Other Loans (80\% Financed) System Cost: Cost:

$\begin{array}{rrrrrrrr} & \$ 60,650 \$ & 60,800 & \$ 76,000 & \$ 101,450 \mathrm{~kW} & \text { Total Genset } & \text { Controls: } & \text { Total System: } \\ 10 \% & 8 \% & 500 & 312000 & \$ 42,000 & \$ 354, \mathbf{0 0 0} \\ 10 & 5 & \text { Installed } & 300 & 188000 & \$ 35,000 & \$ \mathbf{2 2 3 , 0 0 0} \\ 12 & 12 & \text { Cost: } & 150 & \$ 102,000 & \$ 28,000 & \$ 130,000 \\ & (\$ 801.49) & (\$ 1,232.80) & \$ 141,450125 & \$ 88,000 & \$ 25,450 & \$ 113,450 \\ (\$ 9,617.93) & (\$ 14,793.66) & 100 & \$ 76,000 & \$ 25,450 & \$ 101,450 \\ & & & 70 & \$ 68,000 & \$ 25,450 & \$ 93,450\end{array}$

Eng Rating

$100 \mathrm{~kW}$ 


\begin{tabular}{|c|c|c|}
\hline \multicolumn{2}{|l|}{ Thermal Energy Produced: } & Thermal Energy Required: \\
\hline $100 \mathrm{~kW}$ rated & & \multirow{6}{*}{\begin{tabular}{|} 
7,142,857Btuh \\
2092.8in kW \\
$60,000,000,000$ Btu per year \\
$\$ \mathbf{2 3 5 , 2 9 4 A n n u a l ~ c o s t ~ o f ~ W V O ~ a t ~ G i v e n ~ v a l u e ~}$
\end{tabular}} \\
\hline 200kW Thermal (roughly) & & \\
\hline 682,600 In Btuh & & \\
\hline $5,733,840,000$ Btu per year & & \\
\hline 6.69gph WVO at $85 \%$ efficiency & & \\
\hline \$0.40WVO \$/gal & \multirow{4}{*}{$\begin{array}{r}\text { Infl.Rate: } \\
0.01 \\
\end{array}$} & \\
\hline \$2.68Avoided cost/hr & & $0.046 \$ /$ gallon production \\
\hline$\$ 22,486$ Savings per year & & NOT USED(Rule of Thumb) \\
\hline $\mathbf{9 . 6} \% \%$ thermal produced vs. load & & $\$ 460,000$ at $10 \mathrm{M}$ gpy BD \\
\hline
\end{tabular}

\section{Plant Electrical Consumption:}

Ave kW Use

Peak kW Need

$\mathrm{kWh} /$ year

Value \$/kwh

Value of kWh displaced:

Rule of thumb:
300

798,000

0.08

$\$ 63,840.00$

95Ave kW usage
Genset Fuel Consumption:

kW:Gph (diesel)

$\begin{array}{rr}30 & 2.6 \\ 50 & 4.4 \\ 70 & 5.6 \\ 100 & 8.6 \\ 125 & 10.1 \\ 150 & 11.9 \\ 300 & 26.0 \\ 500 & 42.0\end{array}$


Table A-5. Biodiesel Facility Straight Vegetable Oil Cogeneration Income Statement

\begin{tabular}{|c|c|c|c|c|c|c|c|c|c|}
\hline & & 1 & 2 & 3 & 4 & 5 & 6 & 7 & 8 \\
\hline kW Actual & & 100 & 100 & 100 & 100 & 100 & 100 & 100 & 100 \\
\hline O\&M & $\$$ & $12,392 \$$ & $12,516 \$$ & $12,641 \$$ & $12,767 \$$ & $12,895 \$$ & $13,024 \$$ & $13,154 \$$ & 13,286 \\
\hline Insurance & $\$$ & $12,000 \$$ & $12,240 \$$ & $12,485 \$$ & $12,734 \$$ & $12,989 \$$ & $13,249 \$$ & $13,514 \$$ & 13,784 \\
\hline Corp. OH & $\$$ & $8,000 \$$ & $8,160 \$$ & $8,323 \$$ & $8,490 \$$ & $8,659 \$$ & $8,833 \$$ & $9,009 \$$ & 9,189 \\
\hline Engine Loan & $\$$ & $14,794 \$$ & $14,794 \$$ & $14,794 \$$ & $14,794 \$$ & 14,794 & & & \\
\hline Other Loan & $\$$ & $9,618 \$$ & $9,618 \$$ & $9,618 \$$ & $9,618 \$$ & $9,618 \$$ & $9,618 \$$ & $9,618 \$$ & 9,618 \\
\hline Fuel Cost & $\$$ & $27,740 \$$ & $27,740 \$$ & $27,740 \$$ & $27,740 \$$ & $27,740 \$$ & $27,740 \$$ & $27,740 \$$ & 27,740 \\
\hline Total Expenses & $\$$ & $84,544 \$$ & $85,068 \$$ & $85,601 \$$ & $86,143 \$$ & $86,696 \$$ & $72,464 \$$ & $73,036 \$$ & 73,618 \\
\hline$\$ / k w h$ & $\$$ & $0.068 \$$ & $0.068 \$$ & $0.068 \$$ & $0.068 \$$ & $0.068 \$$ & $0.063 \$$ & $0.063 \$$ & 0.063 \\
\hline Income from KWH Sales & $\$$ & $2,285 \$$ & $32,150 \$$ & $32,150 \$$ & $32,150 \$$ & $32,150 \$$ & $29,786 \$$ & $29,786 \$$ & 29,786 \\
\hline Value of Thermal used internally & & $\$ 22,486 \$$ & $22,711 \$$ & $22,938 \$$ & $23,167 \$$ & $23,399 \$$ & $23,633 \$$ & $23,869 \$$ & 24,108 \\
\hline Value of kWh used internally & $\$$ & $51,072 \$$ & $51,583 \$$ & $52,099 \$$ & $52,620 \$$ & $53,146 \$$ & $53,677 \$$ & $54,214 \$$ & 54,756 \\
\hline Gross Income & $\$$ & $75,842 \$$ & $106,444 \$$ & $107,187 \$$ & $107,937 \$$ & $108,695 \$$ & $107,096 \$$ & $107,869 \$$ & 108,650 \\
\hline$-\$ 20,000.00 \$$ & & $(8,701) \$$ & $21,376 \$$ & $21,586 \$$ & $21,794 \$$ & $21,999 \$$ & $34,632 \$$ & $34,834 \$$ & 35,032 \\
\hline
\end{tabular}




\begin{tabular}{|c|c|c|c|c|c|c|c|c|c|c|c|c|c|}
\hline & 9 & & 10 & \multicolumn{3}{|c|}{11} & 12 & \multicolumn{3}{|c|}{13} & \multicolumn{2}{|l|}{14} & 15 \\
\hline & 100 & & 100 & & 100 & & 100 & & 100 & & 100 & & 100 \\
\hline$\$$ & 13,419 & $\$$ & 13,553 & $\$$ & 13,688 & $\$$ & 13,825 & $\$$ & 13,964 & $\$$ & 14,103 & $\$$ & 14,244 \\
\hline$\$$ & 14,060 & $\$$ & 14,341 & $\$$ & 14,628 & $\$$ & 14,920 & $\$$ & 15,219 & $\$$ & 15,523 & $\$$ & 15,834 \\
\hline$\$$ & 9,373 & $\$$ & 9,561 & $\$$ & 9,752 & $\$$ & 9,947 & $\$$ & 10,146 & $\$$ & 10,349 & $\$$ & 10,556 \\
\hline$\$$ & 9,618 & $\$$ & 9,618 & $\$$ & - & $\$$ & - & $\$$ & - & $\$$ & - & $\$$ & - \\
\hline$\$$ & 27,740 & $\$$ & 27,740 & $\$$ & 27,740 & $\$$ & 27,740 & $\$$ & 27,740 & $\$$ & 27,740 & $\$$ & 27,740 \\
\hline$\$$ & 74,210 & $\$$ & 74,813 & $\$$ & 65,809 & $\$$ & 66,433 & $\$$ & 67,069 & $\$$ & 67,716 & $\$$ & 68,374 \\
\hline$\$$ & 0.063 & $\$$ & 0.063 & $\$$ & 0.063 & $\$$ & 0.063 & $\$$ & 0.063 & $\$$ & 0.063 & $\$$ & 0.063 \\
\hline$\$$ & 29,786 & $\$$ & 29,786 & $\$$ & 29,786 & $\$$ & 29,786 & $\$$ & 29,786 & $\$$ & 29,786 & $\$$ & 29,786 \\
\hline$\$$ & 24,349 & $\$$ & 24,592 & $\$$ & 24,838 & $\$$ & 25,087 & $\$$ & 25,337 & $\$$ & 25,591 & $\$$ & 25,847 \\
\hline$\$$ & 55,304 & $\$$ & 55,857 & $\$$ & 56,415 & $\$$ & 56,979 & $\$$ & 57,549 & $\$$ & 58,125 & $\$$ & 58,706 \\
\hline$\$$ & 109,439 & $\$$ & 110,235 & $\$$ & 111,040 & $\$$ & 111,852 & $\$$ & 112,673 & $\$$ & 113,502 & $\$$ & 114,339 \\
\hline$\$$ & 35,229 & $\$$ & 35,422 & $\$$ & 45,231 & $\$$ & 45,419 & $\$$ & 45,604 & $\$$ & 45,786 & $\$$ & 45,965 \\
\hline & & & & & & & & & & & & 58. & $4 \%$ \\
\hline & & & & & & & & & & & & IRF & \\
\hline
\end{tabular}




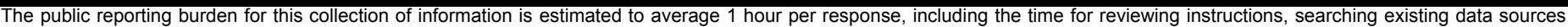

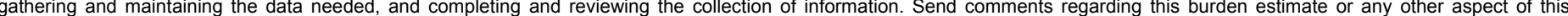

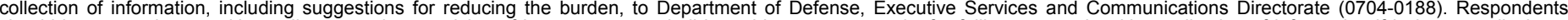

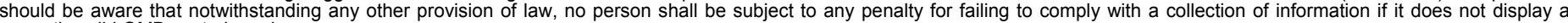
currently valid OMB control number.

PLEASE DO NOT RETURN YOUR FORM TO THE ABOVE ORGANIZATION.

\begin{tabular}{l|l} 
1. & $\begin{array}{l}\text { REPORT DATE (DD-MM-YYYY) } \\
\text { May } 2006\end{array}$ \\
\hline
\end{tabular}

4. TITLE AND SUBTITLE

Green Energy Options for Consumer-Owned Business

3. DATES COVERED (From - To)

5a. CONTRACT NUMBER

DE-AC36-99-GO10337

5b. GRANT NUMBER

5c. PROGRAM ELEMENT NUMBER

6. AUTHOR(S)

Co-opPlus of Western Massachusetts

5d. PROJECT NUMBER

NREL/SR-560-39465

5e. TASK NUMBER

WW88.2002

5f. WORK UNIT NUMBER
7. PERFORMING ORGANIZATION NAME(S) AND ADDRESS(ES)

Co-opPlus of Western Massachusetts

324 Wells Street

Greenfield, MA 01301
8. PERFORMING ORGANIZATION REPORT NUMBER ZAT-4-33658-01

9. SPONSORING/MONITORING AGENCY NAME(S) AND ADDRESS(ES)

National Renewable Energy Laboratory

10. SPONSOR/MONITOR'S ACRONYM(S) NREL

1617 Cole Blvd.

Golden, CO 80401-3393

11. SPONSORING/MONITORING AGENCY REPORT NUMBER NREL/SR-560-39465

\section{DISTRIBUTION AVAILABILITY STATEMENT}

National Technical Information Service

U.S. Department of Commerce

5285 Port Royal Road

Springfield, VA 22161

13. SUPPLEMENTARY NOTES

NREL Technical Monitor: H. Thomas

14. ABSTRACT (Maximum 200 Words)

The goal of this project was to define, test, and prototype a replicable business model for consumer-owned cooperatives. The result is a replicable consumer-owned cooperative business model for the generation, interconnection, and distribution of renewable energy that incorporates energy conservation and efficiency improvements.

\section{SUBJECT TERMS}

renewable energy; cooperative; co-op; Massachusetts; Co-opPlus; Co-op Power; interconnection; National Renewable Energy Laboratory; NREL

\begin{tabular}{|c|c|c|c|}
\hline \multicolumn{3}{|c|}{ 16. SECURITY CLASSIFICATION OF: } & \multirow{2}{*}{$\begin{array}{l}\text { 17. LIMITATION } \\
\text { OF ABSTRACT } \\
\text { UL }\end{array}$} \\
\hline $\begin{array}{l}\text { a. REPORT } \\
\text { Unclassified }\end{array}$ & $\begin{array}{l}\text { b. ABSTRACT } \\
\text { Unclassified }\end{array}$ & $\begin{array}{l}\text { c. THIS PAGE } \\
\text { Unclassified }\end{array}$ & \\
\hline
\end{tabular}

18. NUMBER
OF PAGES

19a. NAME OF RESPONSIBLE PERSON

19b. TELEPONE NUMBER (Include area code) 